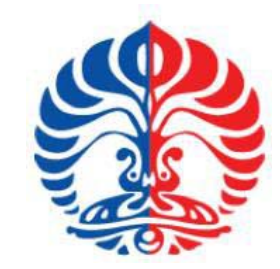

UNIVERSITAS INDONESIA

\title{
EVALUASI APLIKASI E-COMMERCE MENGGUNAKAN EXTENDED WEB ASSESSMENT METHOD (EWAM) DARI PERSPEKTIF KONSUMEN: \\ STUDI KASUS TOKO BUKU ONLINE DI INDONESIA
}

\section{TESIS}

Andi Susilo

0706308036

FAKULTAS ILMU KOMPUTER

PROGRAM STUDI MAGISTER TEKNOLOGI INFORMASI JAKARTA

JANUARI 2010 


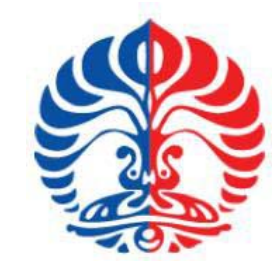

UNIVERSITAS INDONESIA

\section{EVALUASI APLIKASI E-COMMERCE MENGGUNAKAN EXTENDED WEB ASSESSMENT METHOD (EWAM) DARI PERSPEKTIF KONSUMEN: \\ STUDI KASUS TOKO BUKU ONLINE DI INDONESIA}

\section{TESIS}

Diajukan sebagai salah satu syarat untuk memperoleh gelar Magister Teknologi Informasi

Andi Susilo

0706308036

FAKULTAS ILMU KOMPUTER

PROGRAM STUDI MAGISTER TEKNOLOGI INFORMASI

JAKARTA

JANUARI 2010 


\section{HALAMAN PERNYATAAN ORISINALITAS}

Tesis ini adalah hasil karya saya sendiri, dan semua sumber baik yang dikutip maupun dirujuk telah saya nyatakan dengan benar.

$\begin{array}{lll}\text { Nama } & : & \text { Andi Susilo } \\ \text { NPM } & : & \mathbf{0 7 0 6 3 0 8 0 3 6}\end{array}$

Tanda tangan :

Tanggal : 5 Januari 2010 


\section{HALAMAN PENGESAHAN}

Tesis ini diajukan oleh:

Nama

: Andi Susilo

NPM

: 0706308036

Program Studi $\quad$ : Magister Teknologi Informasi

Judul Karya Akhir : Evaluasi Aplikasi E-commerce Menggunakan Extended

Web Assessment Method (EWAM) dari Perspektif

Konsumen: Studi Kasus Toko Buku Online di Indonesia

Telah berhasil dipertahankan di hadapan Dewan Penguji dan diterima sebagai bagian persyaratan yang diperlukan untuk memperoleh gelar Magister Teknologi Informasi pada Program Studi Magister Teknologi Informasi, Fakultas Ilmu Komputer, Universitas Indonesia.

\section{DEWAN PENGUJI}

Pembimbing : Riri Satria, S.Kom., MM. ACP

Penguji : Drs. Widijanto S. Nugroho, M.Math., Ph.D

Penguji : M. Rifki Shihab, B.B.A, M.Sc

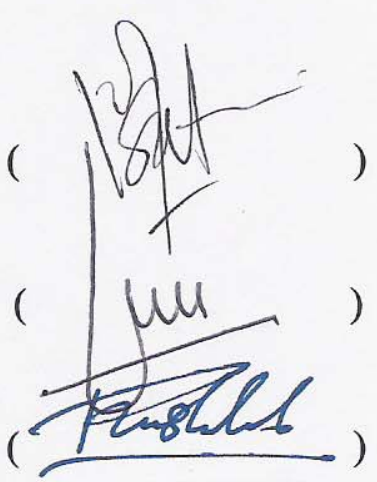

Ditetapkan di : Jakarta

Tanggal : 5 Januari 2010 


\section{KATA PENGANTAR}

Puji syukur saya panjatkan kepada Allah SWT., karena atas ijin dan rahmat-Nya, saya dapat menyelesaikan Tesis yang berjudul "Evaluasi Aplikasi E-Commerce Menggunakan Extended Web Assessment Method (EWAM) dari Perspektif Konsumen: Studi Kasus Toko Buku Online di Indonesia”. Penulisan Tesis ini dilakukan dalam rangka memenuhi salah satu syarat untuk mencapai gelar Magister Teknologi Informasi pada Program Studi Magister Teknologi Informasi, Fakultas Ilmu Komputer, Universitas Indonesia.

Saya menyadari tanpa bantuan dan bimbingan dari berbagai pihak, sejak masa kuliah sampai pada penyusunan Tesis ini sangatlah sulit bagi saya untuk menyelesaikannya. Oleh karena itu, saya mengucapkan terima kasih yang sedalam-dalamnya kepada:

1. Bapak Riri Satria, S.Kom, MM. ACP, selaku dosen pembimbing yang telah menyediakan waktu, tenaga, dan pikiran untuk mengarahkan saya dalam penyusunan Tesis ini;

2. Prof. Dr. Uwe Leimstoll, Competence Center E-Business Basel, University of Applied Sciences Northwestern Switzerland (FHNW) for time and attention to discuss about EWAM and to give me guidance how to implement EWAM method for evaluating e-commerce application on selling books online sector in Indonesia;

3. Bapak Yudho Giri Sucahyo, S.Kom, M.Kom, Ph.D dan Dr. Achmad Nizar Hidayanto S.Kom, M.Kom sebagai Pembimbing Akademis yang telah memberikan arahan selama masa studi saya di MTI-UI;

4. Bapak Drs. Widijanto Satyo Nugroho, M.Math, Ph.D dan Bapak Muhammad Rifki Shihab, B.B.A, M.Sc sebagai Dosen Penguji Tesis;

5. Ayah dan ibu tercinta, istriku, dan anakku tersayang atas kesabaran, pengertian, dan doa tulus yang diberikan. Karya yang aku tuliskan ini tidak berarti apa-apa tanpa keberadaan mereka;

6. Teman-teman sekelas MTI2007FA atas kontribusi dan partisipasinya dalam studi ini; 
7. Bapak Drs. Slamet Abadi, Bapak Drs. Syamsul Abbas Ras, M.Eng, Bapak Drs. Fajar Junaedi EP, M.Kom, Bapak Drs. Sutanto Priyohastono, M.Kes dan Bapak Ahmad Muttaqin, SKM, M.Epid yang telah menyediakan waktu untuk berdiskusi dan memberikan petunjuk terkait Analisis Statistik Deskriptif yang digunakan pada Tesis ini;

8. Teman-temanku Reza, Pak Yoseph, dan Nuri di kelas MTI2007FA yang telah banyak memberikan bantuan dan dorongan semangat dalam menyelesaikan Tesis ini;

9. Serta tak lupa kepada semua pihak yang telah memberikan kontribusi yang sangat berharga dalam penulisan Tesis ini.

Akhir kata, semoga Allah SWT. membalas segala kebaikan semua pihak yang telah membantu dan semoga Tesis ini membawa manfaat baik bagi pengembangan ilmu pengetahuan maupun semua pihak yang berkepentingan.

Jakarta, 5 Januari 2010

Andi Susilo 


\section{HALAMAN PERNYATAAN PERSETUJUAN PUBLIKASI TESIS UNTUK KEPENTINGAN AKADEMIS}

Sebagai sivitas akademik Universitas Indonesia, saya yang bertanda tangan di bawah ini:

$\begin{array}{ll}\text { Nama } & : \text { Andi Susilo } \\ \text { NPM } & : 0706308036\end{array}$

Program Studi : Magister Teknologi Informasi

Fakultas : : Ilmu Komputer

Jenis Karya : Tesis

Demi pengembangan ilmu pengetahuan, menyetujui untuk memberikan kepada Universitas Indonesia Hak Bebas Royalti Non-ekslusif (Non-exclusive Royalty Free Right) atas Tesis saya yang berjudul:

Evaluasi Aplikasi E-Commerce Menggunakan Extended Web Assessment Method (EWAM) dari Perspektif Konsumen: Studi Kasus Toko Buku Online di Indonesia.

Beserta perangkat yang ada (jika diperlukan). Dengan Hak Bebas Royalti Noneksklusif ini Universitas Indonesia berhak menyimpan, mengalihmediakan/formatkan, mengelola dalam bentuk pangkalan data (database). Merawat dan mempublikasikan Tesis saya tanpa meminta izin dari saya selama tetap mencantumkan saya sebagai penulis/pencipta dan sebagai pemilik Hak Cipta.

Demikian pernyataan ini saya buat dengan sebenarnya.

Dibuat di : Jakarta

Pada tanggal : 5 Januari 2010

Yang menyatakan

(Andi Susilo) 


\begin{tabular}{ll}
\multicolumn{1}{c}{ ABSTRAK } \\
Nama Lengkap & : Andi Susilo \\
Program Studi & : Magister Teknologi Informasi \\
Judul & : Evaluasi Aplikasi E-Commerce Menggunakan \\
& Extended Web Assessment Method (EWAM) \\
& dari Perspektif Konsumen: Studi Kasus Toko \\
& Buku Online di Indonesia.
\end{tabular}

Di dunia Internet, banyak situs memiliki tampilan grafis yang menarik, isi terorganisasi dengan baik, namun belum tentu situs-situs tersebut menarik pengunjung untuk datang kembali secara teratur. Banyak perusahaan dan institusi terkejut menemukan bahwa alokasi anggaran biaya yang besar tidak selalu menjamin keberhasilan. Salah satu alasan mengapa konsumen potensial akhirnya mengalihkan pandangan dan tidak melanjutkan kepada tahapan pembelian adalah bahwa sebuah situs web memiliki tingkat fokus kepada konsumen yang rendah. Terdapat kebutuhan vital bagi penjual online untuk merancang situs-situs web mereka menurut kebutuhan potensial konsumen mereka. Extended Web Assessment Method (EWAM) merepresentasikan sebuah instrumen untuk membuat pernyataan umum pada kualitas situs web komersial dari perspektif konsumen. EWAM adalah sebuah alat evaluasi yang secara spesifik dibuat untuk menilai aplikasi-aplikasi e-commerce. EWAM dikembangkan oleh Petra Schubert dan Dorian Selz di Universitas St. Gallen, Swiss. Metode ini secara utama mengintegrasikan temuan dari model TAM Davis dan teori TRA dari Fishbein dan Ajzen. EWAM sebuah metode yang didasarkan kepada kisi evaluasi mencakup sekumpulan kriteria untuk menilai kualitas dan keberhasilan aplikasiaplikasi e-commerce yang fokus kepada perspektif konsumen dan fitur-fitur yang spesifik dari Internet sebagai media. Dalam studi ini, peneliti menggunakan EWAM tool yang dibuat dengan aplikasi berbasis web Google Apps untuk mengevaluasi aplikasi e-commerce penjualan buku online di Indonesia. Empat situs web toko buku online telah dipilih dan satu situs web amazon.com sebagai Standar De Facto. Temuan dari riset ini adalah bahwa situs-situs web penjualan buku online di Indonesia yang dievaluasi belum memenuhi ekspektasi dari konsumen ditunjukkan dengan nilai $(<+1$, skor +1 artinya baik) pada jangkauan skala nilai $(-2 /+2)$ yaitu balaipustakaonline.com (0.31) sebagai situs web terburuk, gramediaonline.com (0.35), erlangga.co.id (0.67), dan kutukutubuku.com (0.73) sebagai Best Practice Profile.

Kata-kata Kunci: e-commerce, EWAM, penilaian web, kisi evaluasi, dan metode

xiv + 176 halaman; 30 gambar; 23 tabel; 9 lampiran 


\begin{tabular}{|c|c|}
\hline \multicolumn{2}{|r|}{ ABSTRACT } \\
\hline Full Name & : Andi Susilo \\
\hline Study Program & : Master of Information Technology \\
\hline Title & $\begin{array}{l}\text { : Evaluation of E-Commerce Application Using Extended } \\
\text { Web Assessment Method (EWAM) from Consumer } \\
\text { Perspective: Case Study on Selling Books Online in } \\
\text { Indonesia }\end{array}$ \\
\hline
\end{tabular}

In Internet world, many sites featured fancy graphics, well organized content, but they did not really mean that a site induced the visitor to come back on a regular basis. Thus many companies and institutions discovered with surprise that even comparatively large budgets allocated to the development of their Web sites did not always guarantee success. An often quoted possible reason, why potential customers turn their screens rather off than meddle their way through a purchase order, is a Web sites' low level of consumer focus. There must be a vital interest for online sellers to design their Web sites according to their (potential) customer's needs. The Extended Web Assessment Method (EWAM) represents an instrument for making general statements on the quality of a commercial Web site from a consumer perspective. EWAM is an evaluation tool specifically created for the assessment of electronic commerce applications. EWAM builds on the Web Assessment Method developed at University of St. Gallen, Switzerland by Petra Schubert and Dorian Selz. It mainly integrates findings from Davis's TAM and Fishbein \& Ajzein' TRA. EWAM the method is based on an evaluation grid that includes a set of criteria with which to appraise the quality and success of ecommerce applications. The focus is on consumer perspectives and the specific features of the Internet as a medium. In this study, researcher used the EWAM tool that built with Google Apps Web Based Application for evaluation of e-shops whose main business is selling books. Four Web sites have been selected in Indonesia and one Web site amazon.com as De Facto Standard. The findings show that most of the Web sites in Indonesia assessed do not fully meet the expectations of consumers. Four Web sites have overall scores below $+1(<+1$, score +1 means "good") from range $(-2 /+2)$. The following overall score for each Web site result: balaipustakaonline.com (0.31) as The Worst Practice Profile, gramediaonline.com (0.35), erlangga.co.id (0.67), and kutukutubuku.com (0.73) as The Best Practice Profile.

Keywords: e-commerce, EWAM, e-shops, web assessment, evaluation, and method

xiv + 176 pages; 30 figures; 23 tables; 9 appendixes 


\section{DAFTAR ISI}

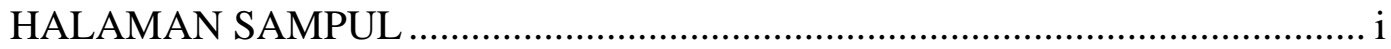

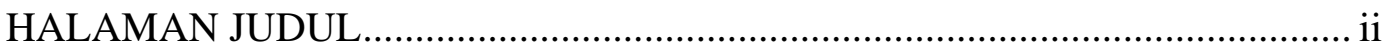

HALAMAN PERNYATAAN ORISINALITAS ................................................ iii

HALAMAN PENGESAHAN ........................................................................... iv

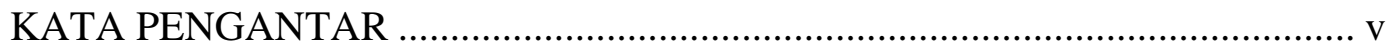

LEMBAR PERSETUJUAN PUBLIKASI TESIS ............................................ vii

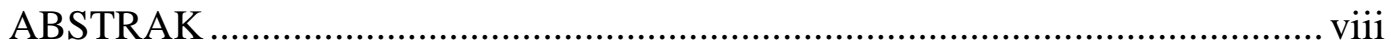

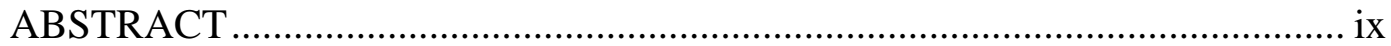

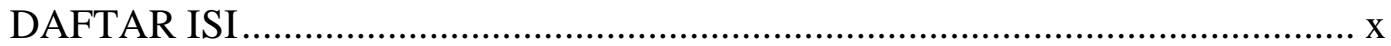

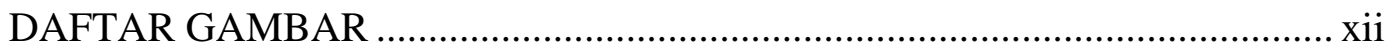

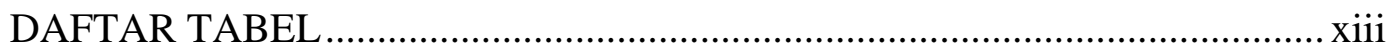

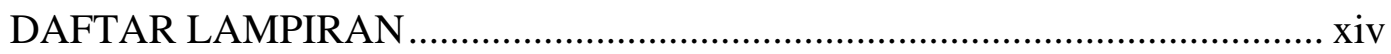

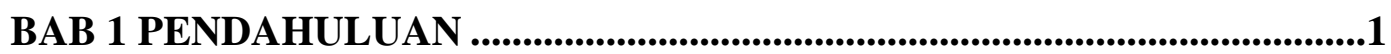

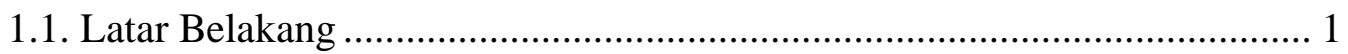

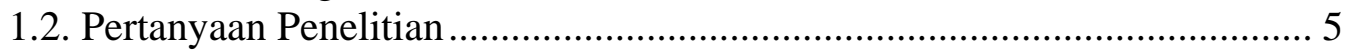

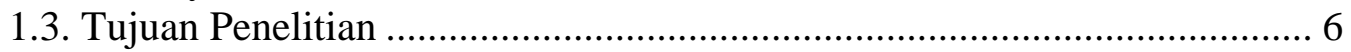

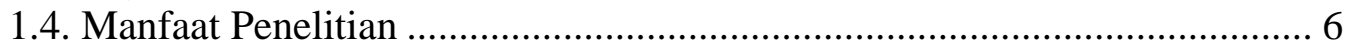

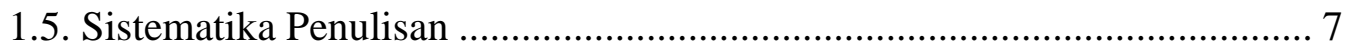

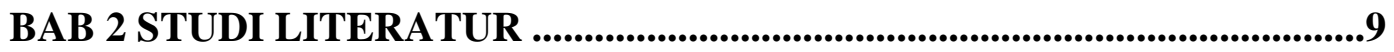

2.1. Kondisi ICT di Indonesia ......................................................................... 9

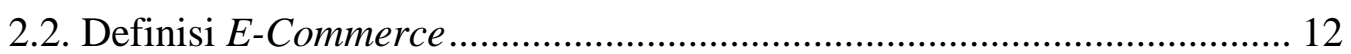

2.3. Penerapan E-Commerce di Indonesia ...................................................... 14

2.4. Model Evaluasi dan Penilaian Web .......................................................... 18

2.4.1. Fase Transaksi dalam Pasar Elektronik........................................... 19

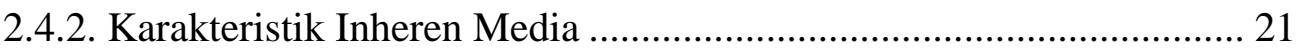

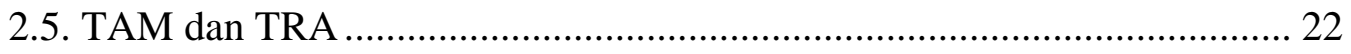

2.6. Extended Web Assessment Method (EWAM) ........................................... 24

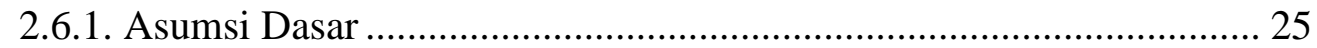

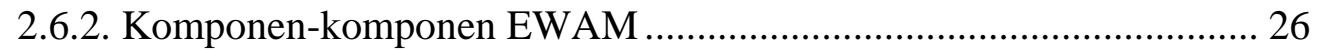

2.6.3. Peringkat Penting .................................................................................... 27

2.6.4. Pengumpulan Data menggunakan EWAM Tool ................................. 28

2.6.5. Analisis dan Persiapan Data............................................................ 29

2.6.6. Laporan Penilaian Web Individu .................................................... 29

2.6.7. Strategi Umum EWAM..................................................................... 30

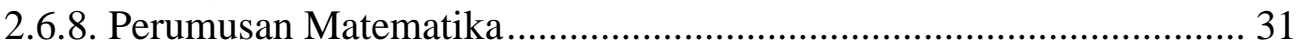

BAB 3 METODOLOGI PENELITIAN .................................................................37

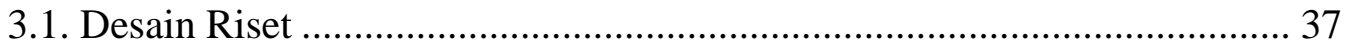

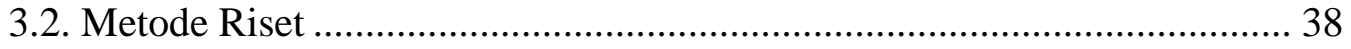

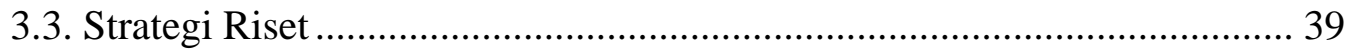

3.4. Penentuan Asesor dan Situs Web yang Diuji............................................. 40

3.5. Metode Pengumpulan Data ..................................................................... 43

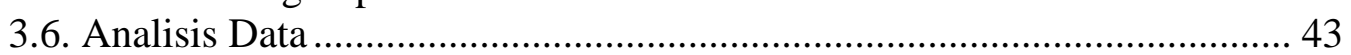




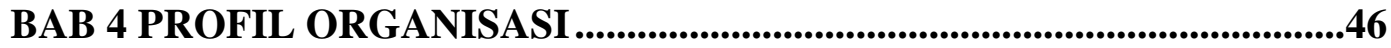

4.1. Situs Web 1: Toko Buku Gramedia (www.gramediaonline.com) ............. 46

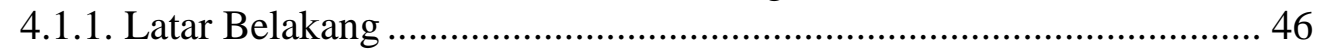

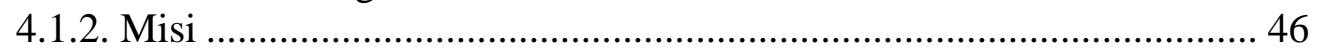

4.1.3. Ragam Produk dan Dukungan Pemasok .......................................... 47

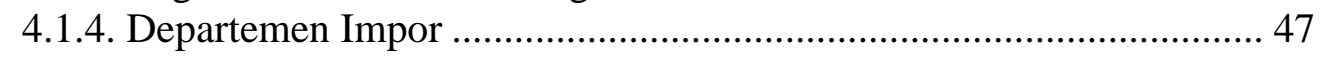

4.2. Situs Web 2: Penerbit Erlangga (www.erlangga.co.id) ............................ 48

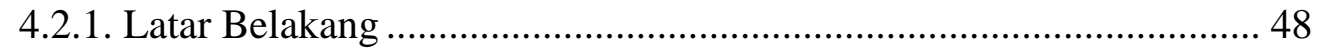

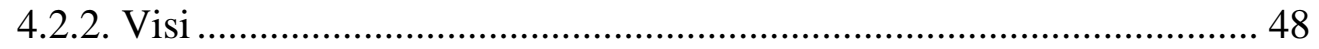

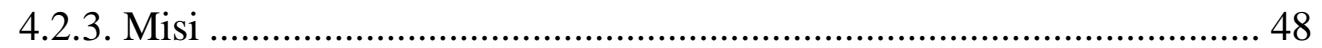

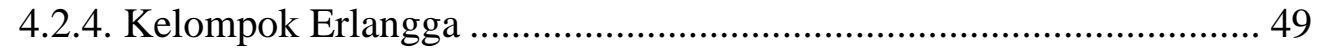

4.3. Situs Web 3: PT. Balai Pustaka (www.balaipustakaonline.com) .............. 50

4.3.1. Dasar Hukum ..................................................................................... 50

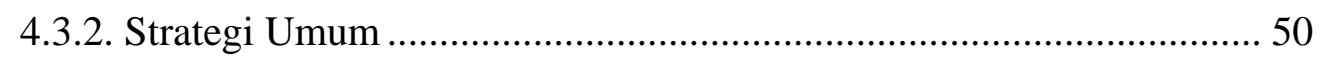

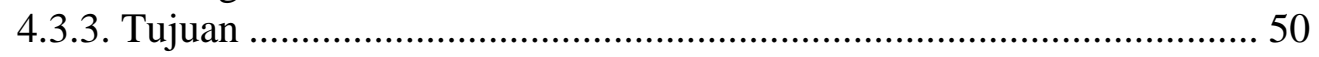

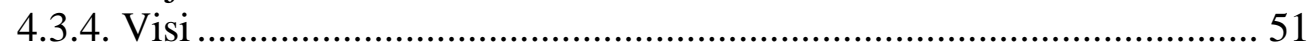

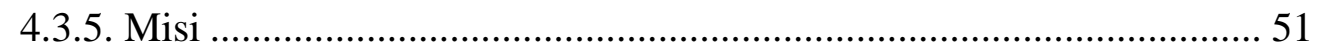

4.4. Situs Web 4: Kutukutubuku (www.kutukutubuku.com) ........................... 52

4.5. Situs Web 5: Toko Buku Amazon (www.amazon.com) .......................... 52

BAB 5 PENGUMPULAN DAN ANALISIS DATA ...................................55

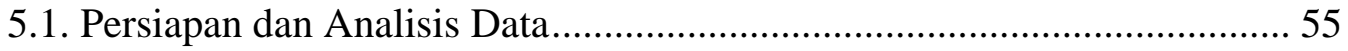

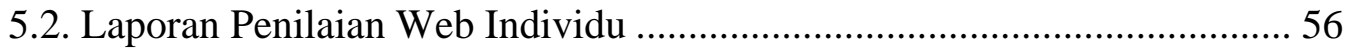

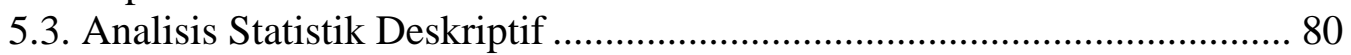

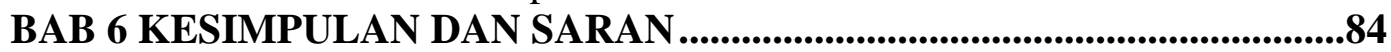

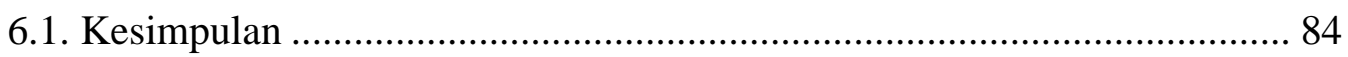

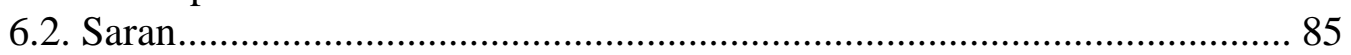

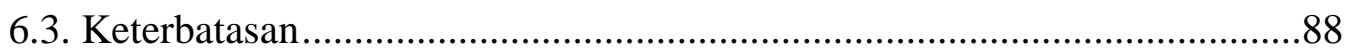

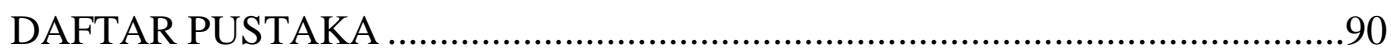

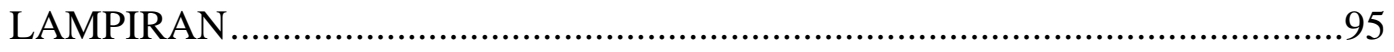




\section{DAFTAR GAMBAR}

Gambar 1.1 Top 10 Negara-negara Internet Asia ............................................... 2

Gambar 1.2 Persentase Rumahtangga yang Akses Internet di Luar Rumah........... 4

Gambar 2.1 Pelanggan seluler analog dan digital di Indonesia ......................... 11

Gambar 2.2 Pengguna Internet di Indonesia pada jangkauan tahun 1995-2000 ... 12

Gambar 2.3 Strategi pendistribusian dan pengelolaan pengetahuan..................... 15

Gambar 2.4 Fase-fase Transaksi Tradisional .................................................. 19

Gambar 2.5 Model Fase Transaksi Berkelanjutan .............................................. 20

Gambar 2.6 Diagram Theory of Reasoned Action (TRA)................................... 22

Gambar 2.7 Diagram Kausal Technology Acceptance Model (TAM) ................... 22

Gambar 2.8 Diagram Extended Web Assessment Method (EWAM) .................... 27

Gambar 2.9 Dua tahap penilaian: (1) Peringkat penting dan

(2) Evaluasi situs web 28

Gambar 2.10 Perbandingan hasil dari peringkat pentingnya kriteria.................... 30

Gambar 3.1 Desain Riset Evaluasi Aplikasi E-Commerce dengan EWAM ......... 37

Gambar 3.2 Tahap-tahap pelaksanaan penelitian yang akan dilakukan ................38

Gambar 5.1 Rangkuman Evaluasi Web Keseluruhan ......................................... 58

Gambar 5.2 Rangkuman Company Profile Penjualan Buku Online di Indonesia ................................................................ 59

Gambar 5.3 Grafik Perbandingan balaipustakaonline.com, Best Practice Profile, dan Sector Profile.

Gambar 5.4 Grafik perbandingan erlangga.co.id, Best Practice Profile, dan Sector Profile.

Gambar 5.5 Grafik Perbandingan gramediaonline.com,

Best Practice Profile, dan Sector Profile.

Gambar 5.6 Grafik Perbandingan kutukutubuku.com,

Standar De Facto, dan Sector Profile.

Gambar 5.7 Rangkuman penilaian situs web dengan peringkat penting .............. 66

Gambar 5.8 Rangkuman penilaian Toko Buku Online per fase dengan peringkat penting 66

Gambar 5.9 Perbandingan balaipustakaonline.com, BPP, dan SCP dengan peringkat penting.............................................................. 71

Gambar 5.10 Evaluasi strategi balaipustakaonline.com, BPP, dan SCP ............. 72

Gambar 5.11 Perbandingan erlangga.co.id, BPP, dan SCP dengan peringkat penting

Gambar 5.12 Evaluasi strategi erlangga.co.id, BPP, dan SCP ............................. 74

Gambar 5.13 Perbandingan gramediaonline.com, BPP, dan SCP

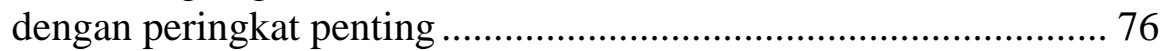

Gambar 5.14 Evaluasi strategi untuk gramediaonline.com, BPP, dan SCP ......... 77

Gambar 5.15 Perbandingan kutukutubuku.com, DFS, dan SCP

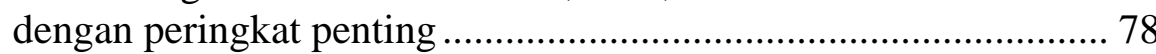

Gambar 5.16 Evaluasi strategi untuk kutukutubuku.com, DFS, dan SCP........... 79 


\section{DAFTAR TABEL}

Tabel 1.1 Statistik Populasi dan Penggunaan Internet Dunia ............................... 1

Tabel 1.2 Populasi dan Penggunaan Internet di Indonesia .................................... 2

Tabel 1.3 Pemilikan telepon rumah, HP, dan komputer tahun 2005 ...................... 3

Tabel 2.1 Operator-operator seluler di Indonesia ................................................ 10

Tabel 2.2 Karakteristik-karakteristik Media Inheren ....................................... 21

Tabel 2.3 Evaluasi Strategi ............................................................................. 31

Tabel 2.4 Kriteria $\mathrm{X}_{\mathrm{i}}$, Importance $\mathrm{W}_{\mathrm{i}}$ \& $\mathrm{Wg}_{\mathrm{i}}$, Evaluasi $\mathrm{r}_{\mathrm{i}}$, Weighted Value $\mathrm{R}_{\mathrm{i}} \ldots . .31$

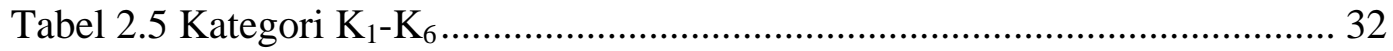

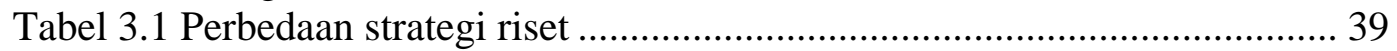

Tabel 3.2 Metode EWAM yang digunakan pada riset sebelumnya..................... 41

Tabel 5.1 Situs-situs web yang dievaluasi dan jumlah asesor ............................. 57

Tabel 5.2 Rangkuman hasil evaluasi 4 situs web................................................ 58

Tabel 5.3 Satu set data yang teragregasi balaipustakaonline.com ....................... 60

Tabel 5.4 Satu set data yang teragregasi erlangga.co.id ................................... 61

Tabel 5.5 Satu set data yang teragregasi gramediaonline.com .............................62 62

Tabel 5.6 Satu set data yang teragregasi kutukutubuku.com .............................. 63

Tabel 5.7 Peringkat Penting dari setiap kategori .................................................. 64

Tabel 5.8 Rangkuman evaluasi situs web dengan peringkat penting..................... 65

Tabel 5.9 Satu set data yang teragregasi dengan peringkat penting:

balaipustakaonline.com .......................................................................... 71

Tabel 5.10 Satu set data yang teragregasi dengan peringkat penting:

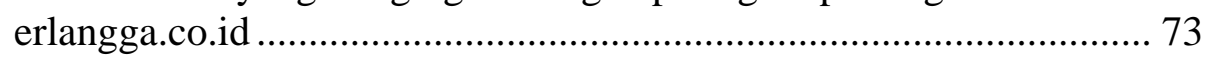

Tabel 5.11 Satu set data yang teragregasi dengan perangkat penting:

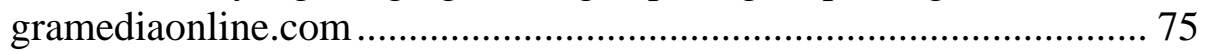

Tabel 5.12 Satu set data yang teragregasi dengan perangkat penting:

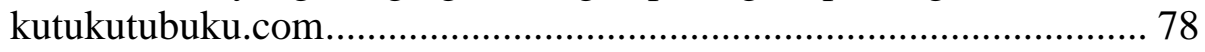

Tabel 5.13 Analisis Statistik Deskriptif dari hasil kuesioner dengan EWAM tool 


\section{DAFTAR LAMPIRAN}

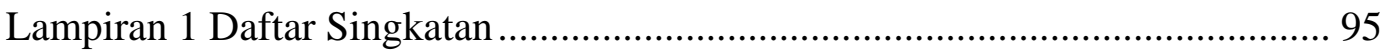

Lampiran 2 Formulir Evaluasi Kriteria............................................................. 96

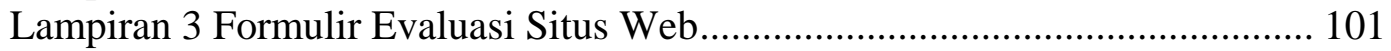

Lampiran 4 Tampilan EWAM Tool ................................................................ 107

Lampiran 5 Kriteria Penilaian Web ................................................................. 108

Lampiran 6 Tabel Frekuensi dan Bar Chart pada Statistik Deskriptif ............... 136

Lampiran 7 Hasil Evaluasi Situs Web .......................................................... 162

Lampiran 8 Hasil Evaluasi Kriteria............................................................. 170

Lampiran 9 Hasil Kalkulasi Situs Web Berdasarkan Peringkat Penting ............ 171 


\section{BAB 1 \\ PENDAHULUAN}

Bab ini mendiskusikan perkembangan aktivitas penggunaan Internet di Indonesia, penerapan aplikasi e-commerce, dan permasalahan yang terjadi. Bab ini disusun menjadi beberapa bagian yaitu latar belakang, pertanyaan penelitian, tujuan penelitian, manfaat penelitian dan sistematika penulisan.

\subsection{Latar Belakang}

Tabel 1.1 memperlihatkan Statistik Populasi Pengguna Internet Dunia berdasarkan Internet World Stats (30 Juni 2009) yang menunjukkan bahwa wilayah Asia memperoleh peringkat pertama pengguna Internet di dunia yaitu 704.213.930 pengguna, disusul kemudian peringkat kedua adalah negara-negara di wilayah Eropa sebanyak 402.380.474 pengguna.

Tabel 1.1 Statistik Populasi dan Penggunaan Internet Dunia

\begin{tabular}{|c|c|c|c|c|c|c|}
\hline \multicolumn{7}{|c|}{ WORLD INTERNET USAGE AND POPULATION STATISTICS } \\
\hline World Regions & $\begin{array}{l}\text { Population } \\
\text { (2009 Est.) }\end{array}$ & $\begin{array}{c}\text { Internet Users } \\
\text { Dec. } 31,2000\end{array}$ & $\begin{array}{c}\text { Internet Users } \\
\text { Latest Data }\end{array}$ & $\begin{array}{c}\text { Penetration } \\
\text { (\% Population) }\end{array}$ & $\begin{array}{c}\text { Growth } \\
2000-2009\end{array}$ & $\begin{array}{l}\text { Users \% } \\
\text { of Table }\end{array}$ \\
\hline Africa & $991,002,342$ & $4,514,400$ & $65,903,900$ & $6.7 \%$ & $1,359.9 \%$ & $3.9 \%$ \\
\hline Asia & $3,808,070,503$ & $114,304,000$ & $704,213,930$ & $18.5 \%$ & $516.1 \%$ & $42.2 \%$ \\
\hline Europe & $803,850,858$ & $105,096,093$ & $402,380,474$ & $50.1 \%$ & $282.9 \%$ & $24.2 \%$ \\
\hline Middle East & $202,687,005$ & $3,284,800$ & $47,964,146$ & $23.7 \%$ & $1,360.2 \%$ & $2.9 \%$ \\
\hline North America & $340,831,831$ & $108,096,800$ & $251,735,500$ & $73.9 \%$ & $132.9 \%$ & $15.1 \%$ \\
\hline Latin America/Caribbean & $586,662,468$ & $18,068,919$ & $175,834,439$ & $30.0 \%$ & $873.1 \%$ & $10.5 \%$ \\
\hline Oceania / Australia & $34,700,201$ & $7,620,480$ & $20,838,019$ & $60.1 \%$ & $173.4 \%$ & $1.2 \%$ \\
\hline WORLD TOTAL & $6,767,805,208$ & $360,985,492$ & $1,668,870,408$ & $24.7 \%$ & $362.3 \%$ & $100.0 \%$ \\
\hline
\end{tabular}

Sumber: Internet World Stats, 2009

Tabel 1.2 memperlihatkan jumlah pengguna Internet di Indonesia berdasarkan Statistik (Internet World Stats, 2009) yang mencapai 25 juta pengguna dari populasi penduduk Indonesia yaitu sekitar 240.271 .522 jiwa sehingga penetrasinya mencapai $10,4 \%$ dari populasi. Dibandingkan dengan pengguna Internet di tahun 2000 yaitu sebanyak 2 juta pengguna, maka kenaikan pengguna 
Internet di Indonesia tahun 2009 cukup signifikan yaitu sebesar dua belas setengah kalinya.

Tabel 1.2 Populasi dan Penggunaan Internet di Indonesia

\begin{tabular}{|c|c|c|c|c|c|c|}
\hline \multicolumn{7}{|c|}{ ASIA INTERNET USAGE AND POPULATION } \\
\hline$\underline{\mathrm{ASIA}}$ & $\begin{array}{l}\text { Population } \\
\text { (2009 Est.) }\end{array}$ & $\begin{array}{c}\text { Internet Users, } \\
\text { (Year 2000) }\end{array}$ & $\begin{array}{c}\text { Internet Users, } \\
\text { Latest Data }\end{array}$ & $\begin{array}{c}\text { Penetration } \\
\text { (\% Population) }\end{array}$ & \begin{tabular}{|l|} 
User Growth \\
$(2000-2009)$
\end{tabular} & $\begin{array}{l}\text { Users }(\%) \\
\text { in Asia }\end{array}$ \\
\hline Indonesia & $240,271,522$ & $2,000,000$ & $25,000,000$ & $10.4 \%$ & $1,150.0 \%$ & $3.6 \%$ \\
\hline
\end{tabular}

Sumber: Internet World Stats, 2009

Jika dilihat dari jumlah populasi penduduk Indonesia maka penetrasi $10,4 \%$ pengguna Internet dapat diartikan bahwa 89,6\% masyarakat Indonesia belum mendapatkan kesempatan atau tidak dapat mengakses Internet. Kondisi ini sungguh memprihatinkan, sumber daya manusia yang begitu besar namun tidak memiliki fasilitas akses Internet yang memadai.

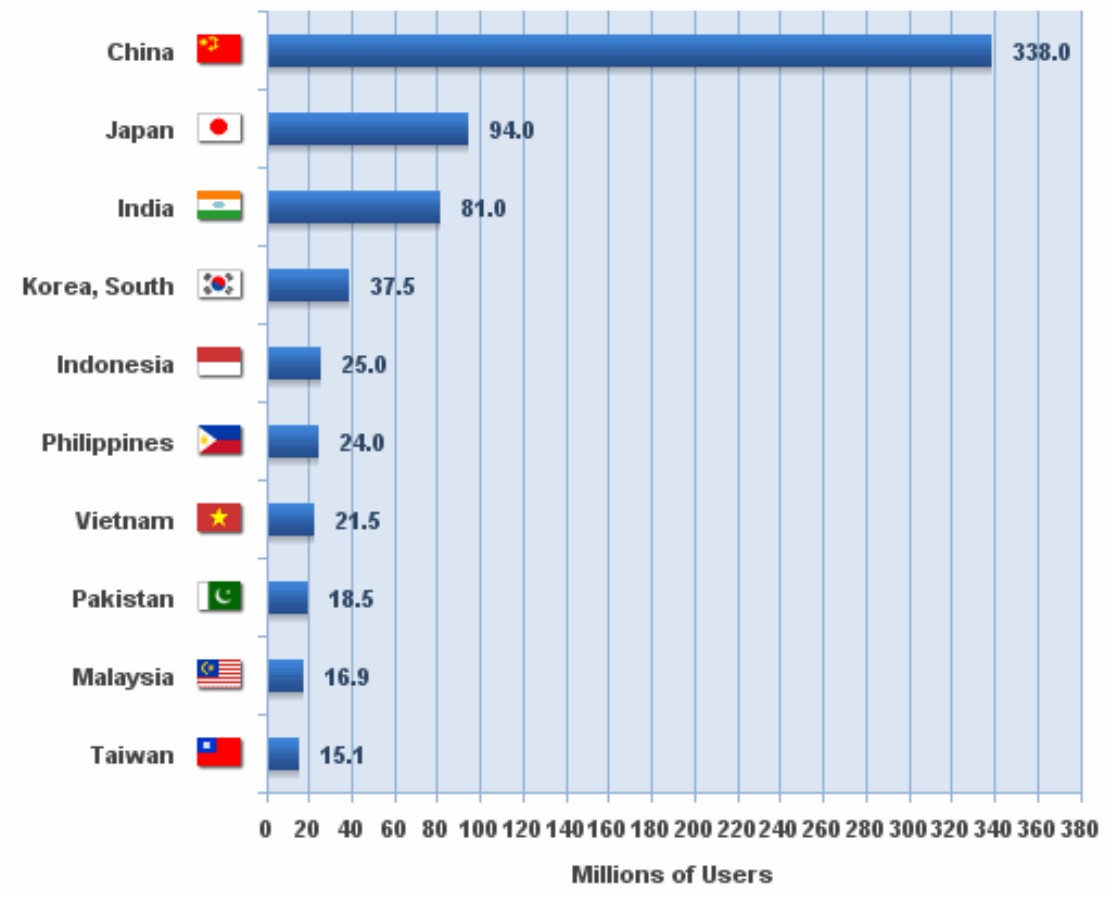

Gambar 1.1 Top 10 Negara-negara Internet Asia

Sumber: Miniwatts Marketing Group (2009): Internet World Stats (2009)

Gambar 1.1 menunjukkan 10 peringkat teratas pengguna Internet di ASIA berdasarkan Miniwatts Marketing Group (2009) pada kuartal ke-2 tahun 2009, 
Indonesia menduduki peringkat ke-5 di Asia sebagai negara pengguna Internet (Internet World Stats, 2009).

Tabel 1.3 Pemilikan telepon rumah, HP, dan komputer tahun 2005

\begin{tabular}{|c|r|r|r|r|r|r|}
\hline \multirow{2}{*}{ Uraian } & \multicolumn{2}{|c|}{ Perkotaan } & \multicolumn{2}{c|}{ Pedesaan } & \multicolumn{2}{c|}{ Perkotaan + Pedesaan } \\
\cline { 2 - 7 } & Jumlah & \multicolumn{1}{c|}{$\%$} & \multicolumn{1}{c|}{ Jumlah } & \multicolumn{1}{c|}{$\%$} & Jumlah & $\%$ \\
\hline Jumlah rumahtangga (juta) & & & & & & \\
\hline - seluruhnya & 25,460 & $\mathrm{x}$ & 33,304 & $\mathrm{x}$ & 58,764 & $\mathrm{x}$ \\
\hline - memiliki telepon & 6,577 & 25,83 & 1,128 & 3,39 & 7,705 & 13,11 \\
\hline - memiliki HP & 8,998 & 35,34 & 2,731 & 8,20 & 11,729 & 19,96 \\
\hline - memiliki telepon dan HP & 4,592 & 18,04 & 0,533 & 1,60 & 5,125 & 8,72 \\
\hline - memilki komputer & 1,952 & 7,67 & 0,209 & 0,63 & 2,161 & 3,68 \\
\hline Jumlah rumahtangga pemi- & & & & & & \\
\hline lik HP (juta) & 8,998 & 100,0 & 2,731 & 100,0 & 11,729 & 100,0 \\
\hline - punya 1 nomor HP & 5,676 & 63,08 & 2,102 & 76,95 & 7,777 & 66,31 \\
\hline - punya 2-4 nomor HP & 2,907 & 32,31 & 0,454 & 16,63 & 3,362 & 28,66 \\
\hline - punya 5 nomor HP & 0,415 & 4,61 & 0,175 & 6,42 & 0,590 & 5,03 \\
\hline
\end{tabular}

Sumber: Berita Resmi Statistik No. 42/IX/14 Agustus 2006

Tabel 1.3 memperlihatkan hasil survei Susenas tahun 2005 (BPS, 2006) tentang Profil Pemanfaatan Teknologi Informasi oleh Masyarakat. Dari aspek gambaran kepemilikan komputer dalam rumahtangga dan sejauh mana penggunaannya untuk akses Internet, menunjukkan bahwa sekitar 2,2 juta rumahtangga dari 58,8 juta rumahtangga keseluruhan (3,68 persen) yang memiliki komputer. Selanjutnya dari 2 juta rumahtangga (7,67 persen) yang memiliki komputer merupakan rumahtangga yang tinggal di perkotaan. Walaupun demikian dari setiap 100 rumahtangga yang memiliki komputer, hanya 27 rumahtangga (sekitar 0,6 juta) yang juga menggunakannya untuk akses Internet.

Gambar 1.2 memperlihatkan aspek sejauh mana akses Internet di luar rumah yang dilakukan oleh anggota rumahtangga dan lokasi tempat mengakses Internet dimana menunjukkan hanya 1,56 persen rumahtangga yang mengakses Internet di warnet, 1,81 persen di kantor atau sekolah, dan 0,29 persen di tempat lain dari seluruh rumahtangga. Khusus untuk akses Internet melalui warnet, 87,65 persen dilakukan oleh rumahtangga yang tinggal di perkotaan. Berikutnya dari 100 rumahtangga di perkotaan, tercatat 3 rumahtangga melakukan akses Internet di warnet (BPS, 2006). 


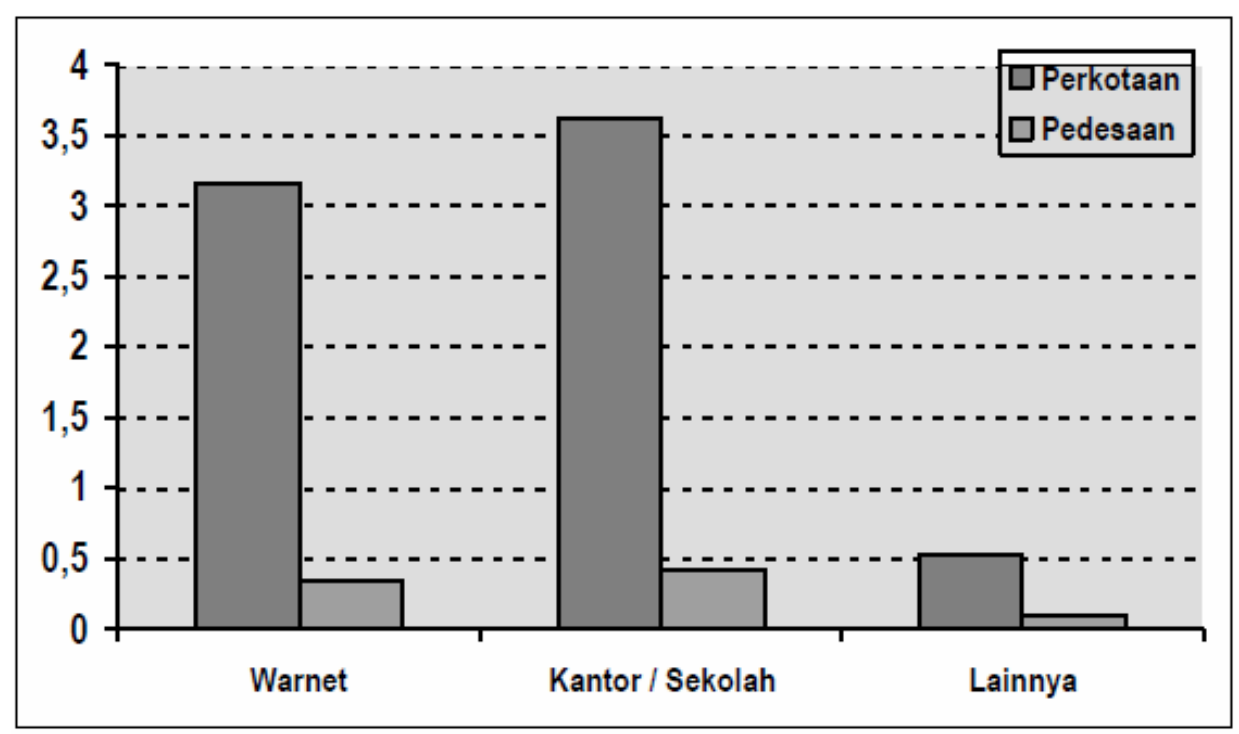

Gambar 1.2 Persentase Rumahtangga yang Akses Internet di Luar Rumah Sumber: Berita Resmi Statistik No. 42/IX/14 Agustus 2006

Purbo (2001) menyatakan bahwa kualitas dari sumber daya manusia akan menjadi kunci keberhasilan bagi aktivitas berbasis Internet termasuk e-commerce. Sayangnya dari 85 juta pekerja Indonesia hanya sekitar 3-4 juta merupakan lulusan universitas. Fokus pada e-commerce terutama pada isu sumber daya manusianya.

Studi-studi yang dikomisikan oleh Asia Foundation (2002) pada pengembangan Information and Communication Technology (ICT) yang digunakan oleh pengusaha kecil dan menengah pada aktivitas e-commerce memperlihatkan polapola penggunaan sebagai berikut:

- Penggunaan yang luas dari e-mail karena keuntungan-keuntungan efisiensi dan biaya;

- Pemakaian situs-situs web lebih kepada promosi daripada penjualan online atau e-commerce menunjukkan bahwa pengusaha e-commerce masih dalam tingkatan dasar implementasi e-commerce;

- Pemakaian yang lazim dari Internet untuk riset dasar; dan

- Kecenderungan untuk melibatkan lebih banyak transaksi offline daripada e-commerce karena menyangkut keamanan. 
Beberapa masalah yang menjadi perhatian peneliti adalah lemahnya kepercayaan yang menjadi penghalang penggunaan Internet dalam transaksi online, pemakaian kartu kredit di negara-negara berkembang masih relatif rendah, situs web masih bersifat informatif dan mudah digunakan saja sedangkan isinya belum dimutakhirkan secara teratur. Terdapat beberapa toko online yang tidak menampilkan harga produknya, biasanya harga produk akan diberitahu kepada konsumen ketika konsumen mengirim private message ke penjual, hal ini memperlambat proses pencarian produk yang diinginkan; lambat dalam membalas e-mail yang dikirim oleh pelanggan; tidak terbuka dalam menentukan harga produk; tidak menjaga data pribadi pelanggan. Atas dasar permasalahanpermasalahan di atas, maka peneliti ingin melaksanakan evaluasi terhadap aplikasi e-commerce pada sektor penjualan buku online. Toko buku online dipilih, karena buku-buku masih sangat diperlukan oleh masyarakat; harga buku-buku di Indonesia masih relatif mahal sehingga dengan membeli buku secara online diharapkan bisa memperoleh harga yang lebih murah; buku-buku bisa memiliki versi tercetak, e-book, dan multimedia; kebanyakan toko buku online di Indonesia masih menggunakan beberapa sistem pembayaran seperti transfer uang ke nomor rekening bank dan Cash On Delivery (COD) dan belum menggunakan kartu kredit artinya bahwa konsumen masih meragukan keamanan pembelian melalui kartu kredit; setidaknya terdapat 37 toko buku online yang terdaftar dan uniknya sebagian besar bukan merupakan penerbit, tetapi hanya penjual ritel yang mengambil buku dagangannya dari distributor yang ditunjuk; Penerbit sebagian besar masih mengandalkan peran distributor dalam menyebarluaskan bukubukunya ke seluruh Indonesia, kondisi ini yang menjadi salah satu penyebab harga buku masih tinggi, karena distributor biasanya mengambil keuntungan sekitar 10\%-20\% dari harga dasar penerbit.

\subsection{Pertanyaan Penelitian}

Berdasarkan latar belakang masalah diatas, maka pertanyaan riset diformulasikan seperti berikut ini: 
Bagaimanakah tingkat keberhasilan aplikasi e-commerce dari perspektif konsumen untuk toko buku online di Indonesia?

\subsection{Tujuan Penelitian}

Berdasarkan pertanyaan penelitian yang diungkapkan sebelumnya, maka tujuan penelitian ini adalah:

- Melakukan evaluasi terkait dengan tingkat keberhasilan aplikasi $e$ commerce dari perspektif konsumen pada sektor usaha penjualan buku online di Indonesia;

- Memberikan rekomendasi perbaikan pada kinerja aplikasi e-commerce yang menunjukkan kelemahan.

\subsection{Manfaat Penelitian}

Manfaat dari penelitian ini adalah sebagai berikut:

- Manfaat Akademis

Penelitian ini menjadi acuan terkait diterapkannya Metode Extended Web Assessment Method (EWAM) sebagai salah satu pendekatan metode yang dipakai untuk menilai situs web dengan aplikasi $e$-commerce pada sektor tertentu.

- Manfaat Praktis

Pertama, bagi Internet Vendor memberikan perbandingan dari kualitas yang berorientasi kepada konsumen dari situs web dengan profil sektornya atau kompetitor secara langsung dan rekomendasi perbaikan yang mungkin digambarkan pada hasilnya. Kedua, bagi Potential Internet Vendor meningkatkan kesadaran pentingnya mengetahui kriteria-kriteria sukses dari situs-situs web e-commerce. Ketiga, bagi Internet Buyers/Users menguji kualitas yang berorientasi kepada pelanggan dari situs web melalui pelanggan berbelanja secara online. 


\subsection{Sistematika Penulisan}

Penelitian ini disusun terstruktur untuk memudahkan pemahaman terhadap masalah yang dibahas dengan sistematika penulisan sebagai berikut:

\section{Bab 1 Pendahuluan}

Bab ini menjelaskan tentang latar belakang, pertanyaan penelitian, tujuan penelitian, manfaat penelitian, dan sistematika penulisan.

\section{Bab 2 Landasan Teori}

Bab ini menguraikan peninjauan literatur sebagai materi pendukung, keterkaitan, pendefinisian, teknik-teknik atau metode-metode yang relevan dengan penelitian ini meliputi: perkembangan ICT di Indonesia, definisi e-commerce, penerapan $e$ commerce di Indonesia, dasar teori munculnya Metode Extended Web Assessment Method (EWAM) meliputi Technology Acceptance Model (TAM) dari Fred Davis, Theory of Reasoned Action (TRA) atau Fishbein model dari Martin Fishbein dan Icek Ajzen, fase transaksi dari pasar elektronik tradisional, karakteristik inheren media sebagai dasar kriteria penilaian web, Karakteristik EWAM meliputi asumsi dasar, komponen-komponen EWAM, pengumpulan data memakai EWAM tool, persiapan data dan analisis, laporan penilaian web secara individu, dan perumusan secara matematis terkait hasil evaluasi situs web dengan peringkat pentingnya.

\section{Bab 3 Metodologi Penelitian}

Bab ini menguraikan langkah-langkah pelaksanaan penelitian yang dapat diuraikan sebagai berikut: Desain penelitian, metode penelitian, strategi penelitian, penentuan pemilihan asesor dan situs web, dan metode pengumpulan dan analisis data.

\section{Bab 4 Profil Toko Buku Online Studi Kasus}

Bab ini menjelaskan profil toko buku online baik yang merupakan toko buku online secara murni artinya menjalankan penjualan buku hanya secara online, 
maupun toko buku yang menjalankan penjualan secara online dan memiliki toko buku secara fisik.

Bab 5 Pengumpulan dan Analisis Data

Bab ini membahas pelaksanaan pengumpulan dan analisis data, yaitu melaksanakan perbandingan sebuah situs web kepada rata-rata sektor, kepada Best Practice Profile atau salah satu dari kompetitornya; membuat laporan penilaian web individu menggunakan representasi grafis melalui tahapan: (a) Merangkum kriteria individu dan hasilnya dalam kategori-kategori Fase Informasi, Fase Kesepakatan, Fase Penyelesaian, Fase Setelah-Penjualan, Komponen Komunitas, Bagian final, dan menghitung total nilai; (b) Membandingkan situs web yang diuji dengan rata-rata sektor dan dengan Best Practice Profile dalam bentuk analisis kuantitatif dan grafis tanpa melihat dari peringkat pentingnya kriteria; (c) Menggambarkan perbandingan hasil dari enam kategori-kategori pertama $(a, b)$ dengan peringkat pentingnya kriteria bagi sebuah perusahaan dan profil sektornya; (d) Membandingkan poin (b) diatas, tetapi dengan melihat peringkat pentingnya kriteria.

\section{Bab 6 Penutup}

Bab terakhir ini memuat kesimpulan dari penelitian, studi lanjutan, dan saransaran yang dibutuhkan. 


\section{BAB 2 \\ STUDI LITERATUR}

Bab ini menguraikan sumber literatur hasil-hasil penelitian sebelumnya sebagai sumber perbandingan, materi pendukung, keterkaitan, pendefinisian, dan teknikteknik atau metode-metode yang relevan dengan penelitian ini.

\subsection{Kondisi ICT di Indonesia}

Negara Indonesia secara demografi terletak di Asia Tenggara, luas area total sebesar 9,8 juta kilometer persegi, 81 persen adalah laut. Negara Indonesia dibagi menjadi 33 provinsi, 268 kabupaten, 73 kotamadya, 4.044 kecamatan, dan 69.065 desa. Populasi diproyeksikan mencapai 210,5 juta jiwa pada tahun 2000, rata-rata pertumbuhan sebesar 1,4 persen dibandingkan dengan tahun sebelumnya. Ratarata pertumbuhan turun dari dua persen dalam periode tahun 1980-90 merefleksikan keberhasilan program keluarga berencana (ITU, 2002).

Indonesia telah meliberalisasikan sektor telekomunikasinya sejak satu dekade lalu. Liberalisasi Information and Communication Technology (ICT) dapat ditelusuri dari adanya dua perusahaan milik negara yaitu P.T. Telekomunikasi Indonesia (Telkom) bagi kebutuhan komunikasi domestik dan P.T. Indonesian Satellite Corporation (Indosat) bagi kebutuhan komunikasi internasional. Layanan telekomunikasi di Indonesia dimulai pada awal tahun 1990-an (ITU, 2002).

Bulan Oktober 1994, Indosat melengkapi sebuah penawaran pembagian saham ke publik. Hal ini diikuti pula oleh privatisasi Telkom pada November 1995. Kompetitor layanan internasional kedua adalah P.T. Satelit Palapa Indonesia (Satelindo) yang mendapatkan lisensi tahun 1993 dan mulai menawarkan layanan pada Agustus 1994. Indosat memiliki 7,5 persen saham di Satelindo sedangkan Telkom 25 persen. Indosat dan Satelindo diwajibkan untuk membayar tarif-tarif yang identik, yang ditentukan oleh pemerintah sehingga mereka melakukan kompetisi dengan memberikan layanan yang terbaik kepada pelanggan. Satelindo diberikan sebuah lisensi seluler mobile nasional dan meluncurkan jaringan Global 
System for Mobile Communications (GSM) digital pada bulan November 1994. Satelindo memiliki keunikan sebagai operator layanan tetap satu-satunya yang telah memiliki investor asing yaitu sejak perusahaan Jerman Deutsche Telekom melakukan akuisisi 25 persen pada tahun 1995 sebesar 676 juta US dollar (ITU, 2002).

Telkom saat itu merupakan operator terbesar dan paling berpengaruh di Indonesia. Telkom memonopoli komunikasi saluran tetap, sampai akhirnya berbagi dengan operator telekomunikasi yang lain kecuali Indosat (ITU, 2002).

Tabel 2.1 Operator-operator seluler di Indonesia

\begin{tabular}{|c|c|c|c|c|c|}
\hline Operator & $\begin{array}{c}\text { Subscribers } \\
\text { Dec 31, } \\
\mathbf{2 0 0 0}\end{array}$ & $\begin{array}{c}\text { Growth } \\
\mathbf{9 9 - 2 0 0 0} \\
(\%)\end{array}$ & Type & Coverage & Owners* \\
\hline Telkomsel & $1^{\prime} 687^{\prime} 339$ & 64.58 & GSM & Nationwide & $\begin{array}{c}\text { Telkom (42.7\%); } \\
\text { Indosat (35.0\%); } \\
\text { KPN (Netherlands) (17.3\%); } \\
\text { PT Setdco Megacell Asia (5.0\%) }\end{array}$ \\
\hline Satelindo & $1^{\prime} 055^{\prime} 306$ & 47.49 & GSM & Nationwide & $\begin{array}{c}\text { Telkom (22.5\%), } \\
\text { Indosat (7.5\%), } \\
\text { Bimagraha Telekomindo (45\%), } \\
\text { DeTeAsia (Germany) (25\%) }\end{array}$ \\
\hline Excelcomindo & $767^{\prime} 250$ & 100.33 & GSM & Nelkom (6.9\%) \\
Rajawali (64.7\%) \\
Komselindo
\end{tabular}

Catatan: Sebelum diumumkan pertukaran saham oleh Telkom dan Indosat.

Sumber: ITU, 2002

Komunikasi mobil berawal pada tahun 1989, ketika Telkom bekerjasama dengan perusahaan Mobisel meluncurkan jaringan analog Nordic Mobile Telephony (NMT), kemudian pada tahun 1991 sebuah jaringan Advanced Mobile Phone System (AMPS) analog nasional diluncurkan (operator Metrocel dan 
Komselindo), bagian yang juga dimiliki oleh Telkom. Pada tahun 1994, perusahaan Satelindo dan Telkomsel diberikan lisensi GSM digital. Lisensi ketiga GSM diberikan kepada Excelcomindo, yang meluncurkan jaringannya pada Oktober 1996. Tabel 2.1 memperlihatkan operator-operator pasar komunikasi bergerak di Indonesia (ITU, 2002).

Pada akhir tahun 2000, terdapat tujuh operator seluler: tiga jaringan GSM-900 nasional dan empat jaringan analog regional. Mereka menyediakan 3,7 juta pelanggan, atau 1,7 persen dari populasi. Kebanyakan pelanggan menggunakan jaringan GSM, sekitar 96 persen dari seluruh pelanggan. Gambar 2.1 memperlihatkan peningkatan jumlah pelanggan seluler untuk jaringan analog dan digital (ITU, 2002).

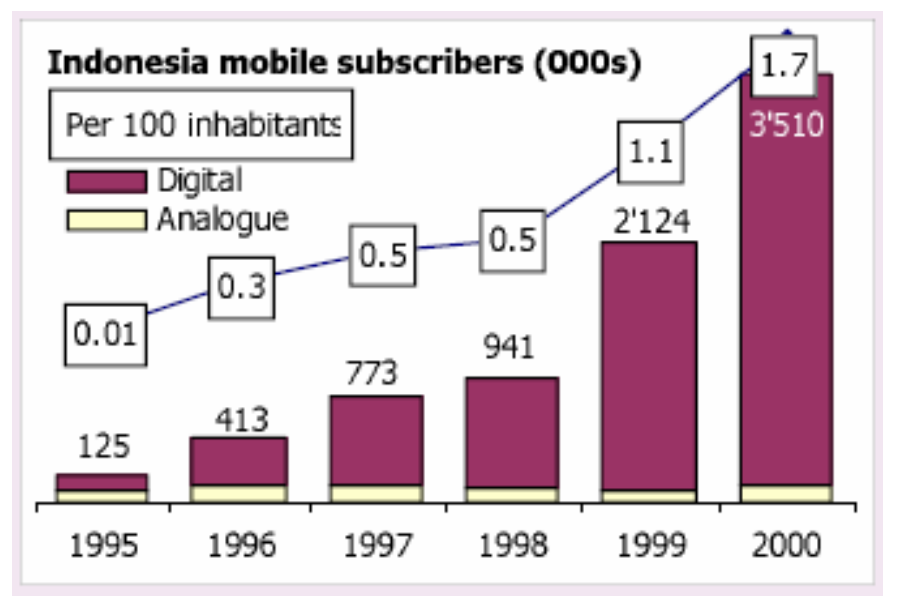

Gambar 2.1 Pelanggan seluler analog dan digital di Indonesia Sumber: ITU, 2002

Indonesia terkoneksi ke Internet secara global pada tahun 1994, sebagai hasil dari usaha-usaha komunitas akademik dan riset. Sambungan pertama adalah jalur 64 Kbps ke Amerika Serikat, yang dibuka pada bulan Mei 1994 oleh jaringan IPTEK (IPTEKnet). P.T. Indo Internet (Indonet) mengklaim sebagai Internet Service Provider (ISP) komersial pertama yang meluncurkan layanan pertamanya pada tahun 1994 (ITU, 2002). Gambar 2.2 menunjukkan pengguna Internet di Indonesia berdasarkan jangkauan tahun 1995-2000. 


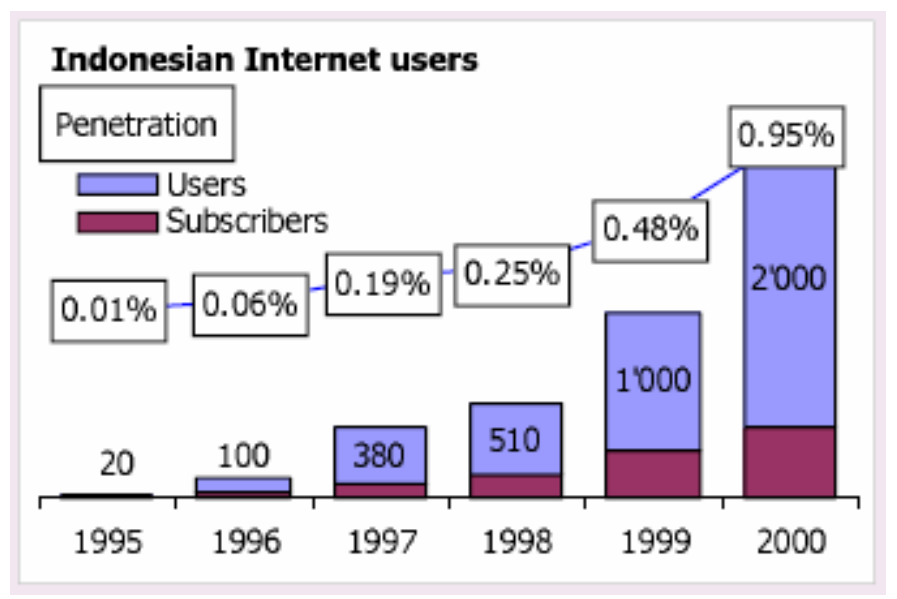

Gambar 2.2 Pengguna Internet di Indonesia pada jangkauan tahun 1995-2000 Sumber: APJII \& ITU, 2002

Pada akhir tahun 1995 terdapat 16 ISP, 20.000 pengguna, dan $640 \mathrm{Kbps}$ konektivitas Internet internasional. Awal tahun 2001, terdapat 150 buah ISP berlisensi dimana 60 ISP menyediakan layanan 150 Mbps bandwidth internasional. Pada akhir tahun 2000, diperkirakan terdapat 400.000 pelanggan Internet dial-up yang dapat menyediakan dua juta pengguna atau di bawah satu persen dari populasi (ITU, 2002).

\subsection{Definisi E-Commerce}

Bartel (Deitel, Deitel \& Steinbuhler, 2001) mendefinisikan "e-commerce involves exchanges among customers, business partners and the vendor.” (p. 8). Misalnya pemasok berinteraksi dengan sebuah perusahaan manufaktur.

E-business merupakan komposisi dari elemen-elemen di atas, namun juga mencakup operasi-operasi yang ditangani dalam bisnisnya sendiri. Misalnya produksi, pengembangan, infrastruktur perusahaan dan manajemen produk (Bartel dikutip di dalam Deitel, Deitel \& Steinbuhler, 2001).

Menurut U.S. Department of State publication (2008) mendefinisikan e-commerce adalah penjualan produk-produk dan servis-servis melalui Internet. 
Menurut Ketel \& Nelson (2008) e-commerce adalah pembelian dan penjualan barang-barang atau servis-servis pada Internet, khususnya World Wide Web. Secara praktis, istilah e-commerce dan sebuah istilah baru, e-business, sering dipakai, jadi menurut mereka pengertian istilah keduanya adalah sama.

Menurut situs web DigitSmith (2006) e-commerce adalah bagian dari e-business, yaitu pembelian, penjualan, dan pertukaran barang-barang atau servis-servis melewati jaringan komputer (misalnya Internet) melalui transaksi-transaksi yang dilakukan secara elektronik.

E-commerce dibagi menjadi empat kategori utama (DigitSmith, 2006): B2B, B2C, $\mathrm{C} 2 \mathrm{~B}$, dan $\mathrm{C} 2 \mathrm{C}$.

\section{- B2B (Business to Business)}

Perusahaan-perusahaan saling membantu menjalankan bisnis mereka, misalnya perusahaan manufaktur menjual kepada distributor-distributor dan penjual-penjual grosir menjual kembali kepada ritel-ritel. Harga berdasarkan kepada kuantitas atau jumlah pemesanan dan biasanya dapat dinegosiasikan.

\section{- B2C (Business to Consumer)}

Pelaku-pelaku bisnis menjual kepada masyarakat umum tipikalnya melalui katalog-katalog yang dikaitkan dengan perangkat lunak shopping cart.

\section{- C2B (Consumer to Business)}

Seorang konsumen mengirimkan proyeknya bersama kriteria biaya yang dipersyaratkan secara online dan dalam hitungan jam perusahaanperusahaan meninjau kebutuhan-kebutuhan konsumen dan melakukan penawaran kepada proyek. Konsumen memeriksa penawaran-penawaran tersebut dan memilih perusahaan yang akan melengkapi proyek. 


\section{- C2C (Consumer to Consumer)}

Terdapat banyak situs yang menawarkan secara bebas kelompokkelompok, lelang-lelang, dan forum-forum dimana setiap individu bisa menjual dan membeli dengan sistem pembayaran online seperti PayPal dimana orang dapat dengan mudah mengirim dan menerima uang secara online.

\subsection{Penerapan E-Commerce di Indonesia}

Kualitas dari sumber daya manusia akan menjadi kunci keberhasilan bagi aktivitas berbasis Internet termasuk e-commerce. Sayangnya dari 85 juta pekerja Indonesia hanya sekitar 3-4 juta merupakan lulusan universitas. Fokus pada e-commerce terutama pada isu sumber daya manusianya. (Purbo, 2001).

Purbo (2001) memusatkan pada maksimalisasi dampak mayoritas masyarakat bisnis dan industri di Indonesia secara umum. Menurut Purbo (2001) terdapat beberapa isu utama yang teridentifikasi:

- Aspek Sosial dan Budaya - kebanyakan berkaitan dengan tingkat pendidikan yang rendah pada pekerja Indonesia.

- Lemahnya pengetahuan TI - peningkatannya dengan cara memperbanyak literatur berbahasa Indonesia.

- Sumber daya manusia yang berkualitas - kurangnya guru-guru dan pendidik-pendidik dengan pengetahuan TI yang kuat.

- Infrastruktur - lemahnya akses telekomunikasi dan Internet. Meskipun infrastruktur TI bisa selalu dipersalahkan sebagai sebuah alasan utama tertinggalnya e-commerce di Indonesia. Purbo (2001) berpendapat bahwa memiliki pengetahuan tentang cara membangun dan mengoperasikan peralatan merupakan pendekatan yang jauh lebih baik dibandingkan dengan hanya memiliki peralatan namun tidak mengetahui cara kerjanya.

Purbo (2001) mengajukan strategi-strategi untuk menciptakan permintaan skala besar dalam masyarakat, dibagi menjadi tiga strategi utama: 
- Memusatkan dan mengintegrasikan pusat-pusat kelompok besar ke Internet - dengan $>20.000$ sekolah-sekolah dan universitas-universitas dan $>20$ juta mahasiswa, sektor pendidikan perlu untuk menciptakan massa dalam jumlah besar di Internet dengan hanya mengorbankan 25.000 saluran dari operator-operator telekomunikasi lokal.

- Memusatkan dan mengadopsi mekanisme e-commerce yang sederhana misalnya, menggunakan e-mail dan Voice Over Internet Protocol (VoIP) sebagai pengganti telepon dan faks; membuat forum atau komunitas B2B menggunakan mailing list dan menggunakan mekanisme pembayaran konvensional.

- Menciptakan tempat pemasaran yang sederhana dan menyebarkannya ke Internet. Meningkatkan transaksi e-commerce dengan pelaku usaha di negara-negara tetangga secara langsung dengan provinsi-provinsi di Indonesia, karena saat ini pemerintah daerah memiliki otonomi yang lebih besar dalam mengelola perekonomian sendiri.

Distribusi dan manajemen pengetahuan menjadi efek yang besar bagi ekonomi Indonesia.

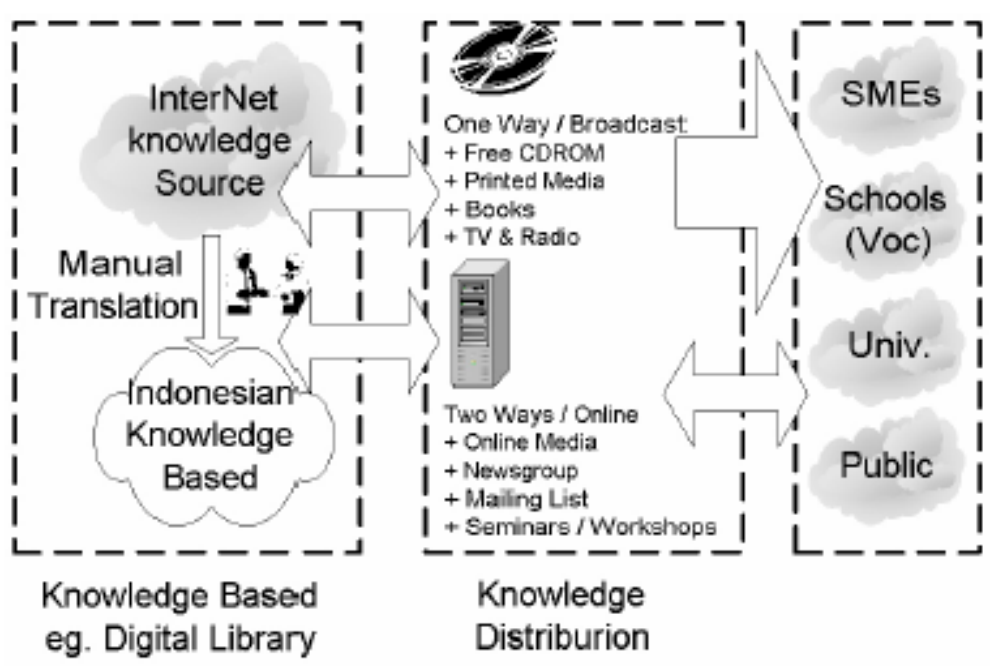

Gambar 2.3 Strategi pendistribusian dan pengelolaan pengetahuan e-commerce di Indonesia

Sumber: Purbo, 2001 
Strategi secara menyeluruh dalam mendistribusikan dan mengelola pengetahuan e-commerce diperlihatkan pada Gambar 2.3. Bisnis online bisa dijalankan dengan modal yang kecil sebagai Usaha Kecil dan Menengah (UKM), demikian juga dengan toko buku online tidak memerlukan modal besar untuk membangun usaha jenis ini. Toko buku mengambil buku melalui distributor-distributor atau ke penerbitnya langsung, keuntungan yang diperoleh bisa mencapai 10-30\% tergantung dari hasil negosiasi dengan pemasok-pemasok atau penerbit buku.

Banyak UKM di Indonesia memperkenalkan pentingnya interaksi face-to-face awal dengan pembeli mereka sebelum menggunakan Internet untuk melengkapi sebuah transaksi penjualan. Pembuat produk sering bertemu dengan pembeli potensial baik melalui pertemuan-pertemuan bisnis atau pameran-pameran. Pembeli biasanya akan membeli sejumlah kecil sampel dari produk dan kemudian menempatkan pemesanan berikutnya melalui e-mail. Pembeli memilih e-mail karena lebih murah daripada komunikasi melalui faks atau telepon. Pengusaha UKM di Indonesia telah berpengalaman dalam melakukan kesepakatan dengan pembeli asing untuk mengadopsi secara cepat fasilitas $e$-mail karena biaya yang lebih murah (Asia Foundation, 2002).

Menurut hasil survei dari Asia Foundation (2002) terdapat dua jenis situs-situs web e-commerce yang beroperasi di Indonesia: 1) situs-situs web berbasis domestik atau internasional yang mempromosikan produk-produk yang dibuat di Indonesia dan 2) situs-situs web tour and travel berbasis domestik atau internasional yang mempromosikan paket-paket perjalanan dan hotel.

Bagi perusahaan-perusahaan manufaktur dan perdagangan, situs-situs web telah membuktikan keuntungan dalam menghasilkan hubungan dengan calon-calon pembeli, namun jarang mengarah kepada penjualan-penjualan lebih lanjut. Mayoritas pembeli-pembeli asing yang telah mengetahui sumber-sumber produk atau mencari sumber-sumber produk dari Indonesia mencari situs-situs web untuk mengidentifikasi pemasok-pemasok potensial yang kemudian mereka akan kunjungi secara langsung nantinya. Pada kebanyakan kasus, pembeli-pembeli ini 
berasal dari perusahaan-perusahaan manufaktur berukuran kecil dan menengah atau operasi-operasi ritel yang membeli dalam volume yang lebih kecil daripada perusahaan-perusahaan manufaktur internasional berukuran besar dan rantairantai ritel yang menempatkan kepada pemesanan dalam jumlah besar pada pameran-pameran perdagangan internasional. Untuk memperkuat keuntungankeuntungan harga, pembeli-pembeli asing berskala kecil ini secara aktif mencari pemasok-pemasok UKM yang mungkin tidak berpartisipasi pada pameran perdagangan di Jakarta atau internasional. Internet menyediakan sebuah kanalkanal yang efisien bagi mereka untuk menemukan pemasok-pemasok mereka (Asia Foundation, 2002).

Beberapa pemasok yang memiliki produk-produk bernilai tinggi dalam volume yang kecil akan berhasil menjual secara langsung melalui Internet. Beberapa pemasok dari Bali, misalnya, memasok penjual-penjual ritel kecil dan individual dari negara-negara lain dan berlanjut dengan transfer-transfer pembayaran dan pengiriman melalui layanan-layanan cepat internasional. Transfer dana dengan biaya tinggi dan pengiriman kilat tidak memungkinkan bagi pembeli-pembeli berskala kecil (khususnya individual) untuk membeli produk-produk bernilai rendah seperti buku-buku dan garmen melalui situs-situs web (Asia Foundation, 2002).

Penerapan e-commerce di Indonesia berdasarkan kategori yang dibuat oleh DigitSmith (2006) masih dikategorikan Business-to-Consumer (B2C) artinya transaksi elektronik dilakukan langsung antara penjual dan pembeli. Penjual menyajikan barang yang akan dijual melalui situs web, kemudian pembeli yang tertarik akan menelusuri barang yang dibutuhkan dan melakukan pembelian. Situs-situs web penjual yang sudah menerapkan aplikasi-aplikasi e-commerce seperti Joomla \& Virtuemart, osCommerce, Wordpress dengan modul WP $e$ commerce, Drupal dengan modul e-commerce Ubercart atau hasil pengembangan sendiri, maka proses pemesanan barang biasanya sudah terintegrasi di dalam Shopping Cart, sedangkan situs-situs web yang tidak menggunakan aplikasi $e$ commerce biasanya pembeli memesan barang dengan mengirimkan e-mail atau 
private message. Metode pembayaran yang digunakan biasanya melalui transfer uang ke nomor rekening penjual, kemudian pembeli melakukan konfirmasi pembayaran dengan melampirkan bukti bayar yang dikirim kembali melalui $e$ mail, setelah penjual menerima bukti pembayaran, maka barang akan segera dikirim ke tempat tujuan pembeli. Metode pembayaran Cash on Delivery (CoD) juga sering dipakai, apabila pembeli menginginkan pembayaran di tempat dan biasanya barang diantar oleh kurir dari karyawan toko penjual online tersebut. Metode pembayaran dengan kartu kredit di Indonesia masih belum banyak diterapkan, masyarakat masih meragukan keamanan pembayaran dengan metode ini, meskipun demikian terdapat beberapa toko online yang sudah menerapkan pembayaran dengan kartu kredit menggunakan layanan pihak ketiga misalnya PayPal yang sudah terjamin keamanan dan kerahasiaan data pembeli. Paypal digunakan karena sudah mendukung transaksi elektronik dengan mata uang Rupiah (IDR) dan dapat digunakan untuk melakukan pembelian dan penjualan barang secara lokal maupun internasional. Layanan-layanan pembayaran pihak ketiga lain seperti Clickbank, 2CO (2CheckOut), dan Google Checkout masih belum bisa diterapkan di Indonesia, karena memang pembatasan wilayah transaksi yang diterapkan oleh pembuat atau pemilik aplikasinya sendiri, selain itu transaksi dengan mata uang Rupiah (IDR) juga belum didukung. Metode pengiriman barang biasanya menggunakan jasa pihak ketiga seperti Tiki, JNE, atau VIP untuk pengiriman lokal sedangkan untuk pengiriman internasional bisa memakai jasa layanan FedEx atau DHL. Tahapan pengiriman barang juga menjadi perhatian penting pembeli, karena terkait dengan ongkos kirim dan lama waktu saat barang dikirim sampai tiba ke tempat tujuan. Oleh karena itu penjual harus memiliki strategi yang tepat untuk tetap menjaga harga barang lebih murah dari toko fisik dan waktu pengiriman barang diusahakan secepat mungkin sampai ke tujuan.

\subsection{Model Evaluasi dan Penilaian Web}

Bagian ini mendeskripsikan model evaluasi dan penilaian web yang terjadi pada transaksi online. 


\subsubsection{Fase Transaksi dalam Pasar Elektronik}

\section{- Pasar Elektronik}

Malone, Yates dan Benjamin pada tahun 1987 (Selz dan Schubert, 1998) berargumentasi bahwa infrastruktur-infrastruktur TI yang baru akan memungkinkan untuk menghindari dan mengeliminasi perantara dalam sistem nilai dan rantai suplai secara khusus dan kemudian mengarah kepada munculnya pasar-pasar elektronik.

Pasar-pasar elektronika adalah pasar-pasar terpenting, institusi-institusi atau mekanisme-mekanisme yang menyediakan pelaku-pelaku pasar untuk mengalokasikan sumber-sumber daya.

\section{- $\quad$ Fase Transaksi}

Sebuah transaksi bisa dibagi kedalam tiga fase yaitu Fase Informasi, Fase Kesepakatan, dan Fase Penyelesaian. Gambar 2.4 memperlihatkan urutan fasefase transaksi tradisional.

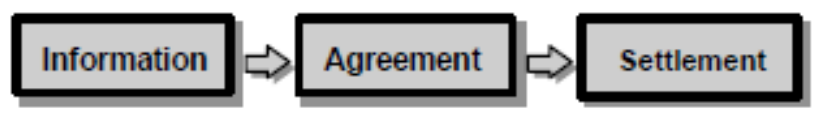

Gambar 2.4 Fase-fase Transaksi Tradisional

Sumber: Internet and the Digital Economy Track, 1998

\section{- Fase Informasi (Information Phase)}

Pada Fase Informasi pelanggan-pelanggan mengumpulkan informasi pada layanan-layanan dan produk-produk potensial. Mereka mencari kemungkinan pemasok-pemasok, menanyakan harga-harga dan persyaratan-persyaratannya. Fase Informasi mencakup kepuasan awal dari kebutuhan-kebutuhan konsumen atas informasi untuk konsiliasi permintaan-permintaan terhadap produk dan layanan beserta penawarannya. 


\section{- Fase Kesepakatan (Agreement Phase)}

Negosiasi antara pemasok-pemasok dan pelanggan-pelanggan berlangsung dalam Fase Kesepakatan. Fase ini menyediakan penentuan kaitan ke sebuah perusahaan antara pemasok dan pembeli yang akan mengarah kepada sebuah kontrak, memperbaiki detail-detail misalnya spesifikasi produk, pembayaran, pengiriman dan lain-lain.

\section{- Fase Penyelesaian (Settlement Phase)}

Tahap konvensional terakhir disebut dengan Fase Penyelesaian. Pengiriman (fisik/virtual) dari produk yang dipesan akan berlangsung selama fase ini. Juga kemungkinan interaksi-interaksi setelah penjualan terjadi seperti jaminan jika terjadi klaim atau layanan help desk yang muncul.

Di dalam lingkungan-lingkungan virtual, derajat interaksi yang lebih jauh menjadi isu sentral. Pembaca yang membeli buku dari Amazon.com secara otomatis adalah sumber potensial untuk resensi buku, karena seseorang sebenarnya juga akan membaca dulu buku yang akan dibeli. Jika banyak pembaca dengan selera yang sama dan cenderung untuk bergabung dengan keinginan dan usahanya sendiri, sebuah komunitas online dari orang-orang yang memiliki pikiran yang sama muncul menjadi sebuah eksistensi. Buah pikir dari komunitas berada di jantung dari revolusi Internet. Hasil pengembangan selanjutnya ditambahkan empat fase kepada proses transaksi-komunikasi seperti diperlihatkan pada Gambar 2.5.

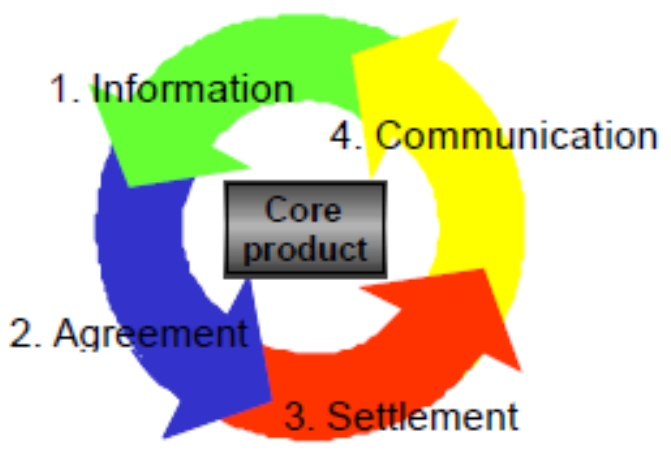

Gambar 2.5 Model Fase Transaksi Berkelanjutan

Sumber: Internet and the Digital Economy Track, 1998 


\section{- Aspek Komunikasi (Community Component)}

Konsep dari "Komunitas", menyediakan sebuah ikatan esensial antara dua transaksi. "Komunikasi" menempatkan diri antara pelanggan-pelanggan dan antara pelanggan dan perusahaan, menghubungkan produk lebih erat kepadanya. Berbagi kepercayaan memungkinkan membangun komunitas yang membangkitkan level tertentu dari kepercayaan antara anggotanya masing-masing dan kemudian menginspirasikan sebuah lingkungan $e$ commerce yang subur. Spar dan Bussang pada tahun 1996 (Schubert \& Selz, 1998) menunjukkan bukti bahwa ketiadaan sebuah aturan-aturan bisnis yang dibentuk pada Internet bisa menghasilkan sebuah lingkungan komersial yang dipengaruhi oleh ketidakamanan.

\subsubsection{Karakteristik Inheren Media}

Model penilaian web selain menguji karakteristik-karakteristik dari fase-fase transaksi pasar elektronik tradisional seperti yang sudah dijelaskan pada subbab 2.4.1 juga menguji karakteristik-karakteristik yang inheren ke Internet, misalnya ketersediaan selama 24 jam. Tabel 2.2 mendaftar karakteristik-karakteristik inti yang dipakai untuk mengembangkan kriteria penilaian web.

Tabel 2.2 Karakteristik-karakteristik Media Inheren

\begin{tabular}{|l|}
\hline Karakteristik-karakteristik Media Inheren \\
\hline 1. Presentasi hypermedia \\
\hline 2. Akses 24-jam (waktu) \\
\hline 3. Antarmuka database (sistem pakar) \\
\hline 4. Keadaan tanpa identitas (anonymity) \\
\hline 5. Keberadaan dimanapun (ubiquity) (Ruang) \\
\hline 6. Komunikasi asinkron \\
\hline 7. Kemungkinan konfigurasi (interactivity) \\
\hline 8. Transfer keuntungan-keuntungan biaya kepada pelanggan \\
\hline
\end{tabular}

Sumber: Schubert \& Selz, 2001 (telah diolah kembali) 


\subsection{TAM dan TRA}

Technology Acceptance Model (TAM) Davis mendeskripsikan efek dari fitur-fitur sistem pada penerimaan pengguna kepada sistem informasi yang baru berbasiskan komputer. Davis memilih 'Fishbein Model', sebuah model tingkah laku secara psikologi sebagai dasar dari pengembangan TAM. Model ini dispesifikasikan oleh Fishbein pada tahun 1967, kemudian analisisnya dipertajam oleh Fishbein dan Ajzen tahun 1975 (Schubert, 2003) dan lebih jauh lagi dielaborasikan ke dalam Theory of Reasoned Action (TRA) yang terlihat pada Gambar 2.6.

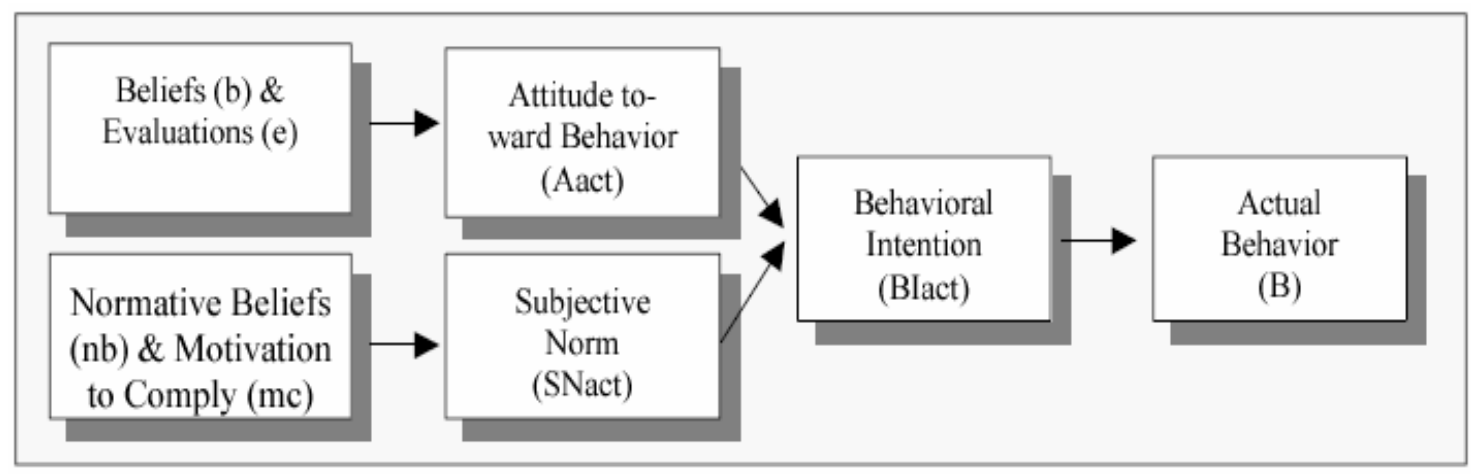

Gambar 2.6 Diagram Theory of Reasoned Action (TRA)

Sumber: Schubert, 2003

TAM mengikuti rantai kausal dari TRA yaitu: "Attitude” $\rightarrow$ "Intention” $\rightarrow$

"Behaviour".

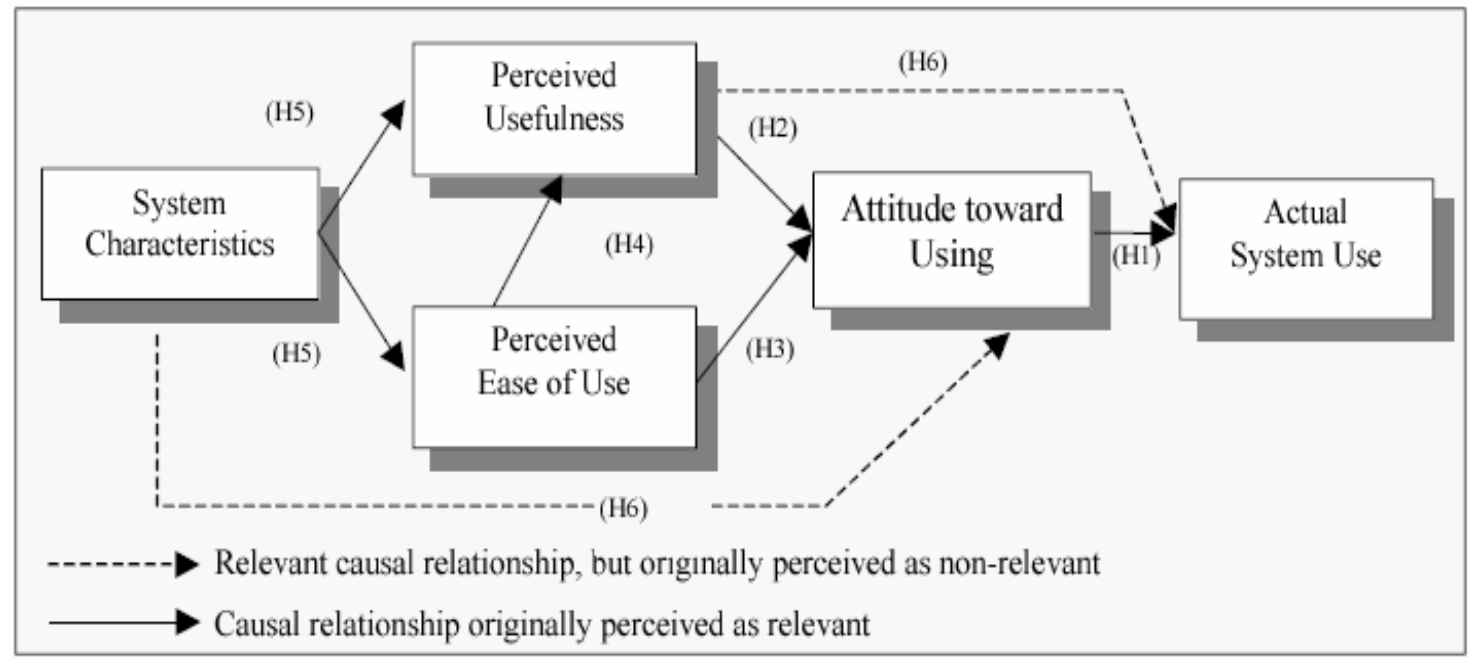

Gambar 2.7 Diagram Kausal Technology Acceptance Model (TAM)

Sumber: Schubert, 2003 
Berdasarkan rantai kausal tersebut David mengajukan model dasar TAM dalam bentuk diagram skematik yang dihasilkan dari studi empiris seperti terlihat pada Gambar 2.7. Hubungan antara variabel-variabel individual adalah dalam bentuk panah-panah. Hubungan hipotetis didefinisikan dalam bentuk dasar yang diujikan secara empiris menggunakan kuesioner yang diikuti oleh analisis regresi.

TAM (Davis \& Venkatesh, 2000) berteori bahwa sebuah niat tingkah laku individu untuk menggunakan sebuah sistem ditentukan oleh dua kepercayaan: pertama, perceived usefulness, didefinisikan sebagai sejauh mana seseorang percaya bahwa dengan menggunakan sistem akan meningkatkan kinerja kerjanya, dan kedua, perceived ease of use, didefinisikan sebagai sejauh mana seseorang percaya bahwa dengan menggunakan sistem akan bebas dari usahanya.

Menurut Davis, dari 120 kuesioner yang dikirimkan kepada karyawan-karyawan di Laboratorium Pengembangan Toronto, Kanada, 112 kuesioner dikembalikan secara lengkap ( $\mathrm{n}=185$, dimana 109 melalui e-mail dan 76 dengan XEDIT). Hasil evaluasi mengkonfirmasikan beberapa hipotesa sebagai berikut:

- (H1), "Attitude" memiliki pengaruh langsung kepada "Actual System Use”.

- (H2), "Usefulness" memiliki efek yang signifikan kepada "Attitude toward Using”.

- $(\mathrm{H} 3)+(\mathrm{H} 4)$, "Ease of Use" memiliki efek kepada "Attitude" dan "Usefulness".

Temuan-temuan lebih jauh yang tidak diharapkan dalam bentuk:

- (H5), "System" memiliki signifikan efek kepada "Ease of Use" tetapi tidak kepada "Usefulness".

- (H6), "Usefulness” memiliki sebuh efek langsung kepada "Actual System Use".

- (H7), "System" mempunyai sebuah efek langsung kepada "Attitude toward Using”. 
Variabel-variabel motivasi "Attitude toward Using”, Perceived Usefulness”, dan "Perceived Ease of Use" menyediakan sebuah kaitan antara fitur-fitur sistem dan tingkah laku dari individu dikaitkan dengan pemakaian sistem informasi yang baru (Actual System Use).

Di dalam TAM, "Subjective Norm" dari Model Fishbein tidak diintegrasikan, Davis tidak mempertimbangkannya. Fishbein dan Ajzein tahun 1975 (Davis \& Venkatesh, 2000) mendefinisikan Subjective Norm sebagai persepsi seseorang bahwa kebanyakan orang yang dianggap penting baginya berfikir bahwa dia seharusnya atau tidak seharusnya melakukan tingkah laku dengan bertanya sebelumnya.

Malhotra dan Galletta (1999) menyimpulkan dalam artikelnya berjudul "Extending the Technology Acceptance Model to Account for Social Influence, Theoritical Bases and Empirical Validation" bahwa Davis tidak memperhitungkan pentingnya "Subjective Norm" dalam TAM. Studi yang diujikan oleh mereka secara empiris menunjukkan kepada fakta bahwa pengaruhpengaruh sosial pengguna juga bermain dalam tugas penting yang dapat diterima dan penggunaan teknologi informasi yang baru. Pengaruh-pengaruh sosial diintegrasikan di dalam EWAM diwujudkan dalam bentuk kriteria yang dinamakan "Trust”.

\subsection{Extended Web Assessment Method (EWAM)}

Metode Penilaian Web orisinil dikembangkan pada permulaan tahun 1997 di Competence Centre for Electronic Markets (CCEM) di Universitas St. Gallen, Swiss bekerjasama dengan perusahaan-perusahaan (Selz dan Schubert, 1998. 1999; Schubert dan Selz, 2001).

Metode ini mendefinisikan sebuah kisi evaluasi dengan sekumpulan kriteria untuk menilai kualitas dan kesuksesan aplikasi-aplikasi e-commerce yang ada, di samping itu fokus yang ketat kepada perspektif konsumen. Kesuksesan dalam menerapkan penawaran produk-produk dan layanan-layanan dipertimbangkan 
dengan referensi kepada fitur-fitur yang spesifik dari media elektronik (Schubert dan Leimstoll, 2001).

\subsubsection{Asumsi Dasar}

Extended Web Assessment Method (EWAM) dibangun berdasarkan hasil pengembangan dari metode penilaian web orisinil (sudah diuraikan pada paragraf pertama subbab 2.6), pengintegrasian temuan-temuan dari Technology Acceptance Model (TAM) dan Theory of Reasoned Action (TRA) dan beberapa pendekatanpendekatan alternatif. Daftar berikut ini adalah pendekatan-pendekatan alternatif evaluasi Web yang diambil selama revisi Web Assessment Method dalam tahun 2000 (Schubert, 2003):

- Ekspektasi-ekspektasi dan peringkat-peringkat dari fitur-fitur kualitas situs Web: hasil dari dua studi pada persepsi pengguna;

- Desain kualitas dari situs-situs Web untuk e-commerce: evaluasi-evaluasi fortune 1000 webmaster;

- Dampak karakteristik-karakteristik situs Web yang diterima pada lalu lintas situs Web;

- Perfect Web pages - bagaimanakah secara nyata terlihat?;

- Web usage mining untuk evaluasi situs Web;

- Konsep-konsep dan model-model prosedur bagi evaluasi Web;

- GomezPro.com;

- JurisNET.

Schubert (2003) mengacu kepada analisis dan kategorisasi detail yang dilakukan oleh Totz et al. Berdasarkan artikel Totz et al., Schubert (2003) menyusun EWAM dalam kategori: (1) market focus (external visibility); (2) subjective (persepsi kualitas pelanggan); dan (3) attribute specific.

Keberhasilan sebuah aplikasi e-commerce harus sesuai dengan kebutuhankebutuhan pengguna menurut "Perceived Usefulness" (Kriteria USEF1USEF15), "Perceived Ease of Use" (Kriteria EOU1-EOU8) dan ”Trust” (Kriteria 
TRUST1-TRUST2) sebagai "Subjective Norm" ditambahkan. Kriteria USEF1USEF15, EOU1-EOU8, dan TRUST1-TRUST2 akan diuraikan lebih lanjut pada BAB 5 dan deskripsi detailnya dapat dilihat pada Lampiran 5.

Ketika mengevaluasi sebuah aplikasi e-commerce, menurut EWAM sebuah situs web pertama dialokasikan ke dalam sebuah sektor. Kondisi ini menyediakan selama evaluasi proses identifikasi sektor-sektor referensi untuk dibandingkan. Agar mampu melaksanakan analisis yang spesifik dan berkualitas tinggi, maka diperlukan untuk merekam peringkat penting per kriteria dan per sektor secara tepat. Peringkat penting per kriteria direkam pada skala dari "tidak penting" (-2), "kurang penting" $(-1)$, "penting" $(+1)$, sampai "paling penting" $(+2)$. Kriteria per kategori dapat dilihat pada Lampiran 2 dan uraian lengkapnya pada Lampiran 5.

\subsubsection{Komponen-komponen EWAM}

Kriteria EWAM pertama kali ditetapkan kepada sebuah kategori kriteria ("Ease of Use", "Usefulness" atau "Trust”) dan dalam tiga kategori ini dibagikan ke satu dari empat fase transaksi dari pasar elektronik (Information Phase, Agreement Phase, Settlement Phase, dan After-Sales Phase), ke komponen komunitas (Community Component), atau ke kategori "kriteria-kriteria yang perlu diseluruh fase (Final Section)". Dibandingkan dengan Web Assessment Method (WAM) yang orisinil, EWAM diperluas dengan mencakupkan After-Sales Phase dan sebuah kelompok kategori "kriteria yang cocok diseluruh fase" (Final Section). Gambar 2.8 memperlihatkan kombinasi dari WAM dengan kategori-kategori "Ease of Use" dan "Usefulness" dari Technology Acceptance Model (TAM) bersama-sama dengan kategori "Trust" yang diambil dari Theory of Reasoned Action (TRA). Dimensi sektor "1..n" mengilustrasikan perluasan dari EWAM dengan profil-profil sektor dan mempertimbangkan perbedaan kriteria individual yang penting di dalam sektor-sektor ini. 


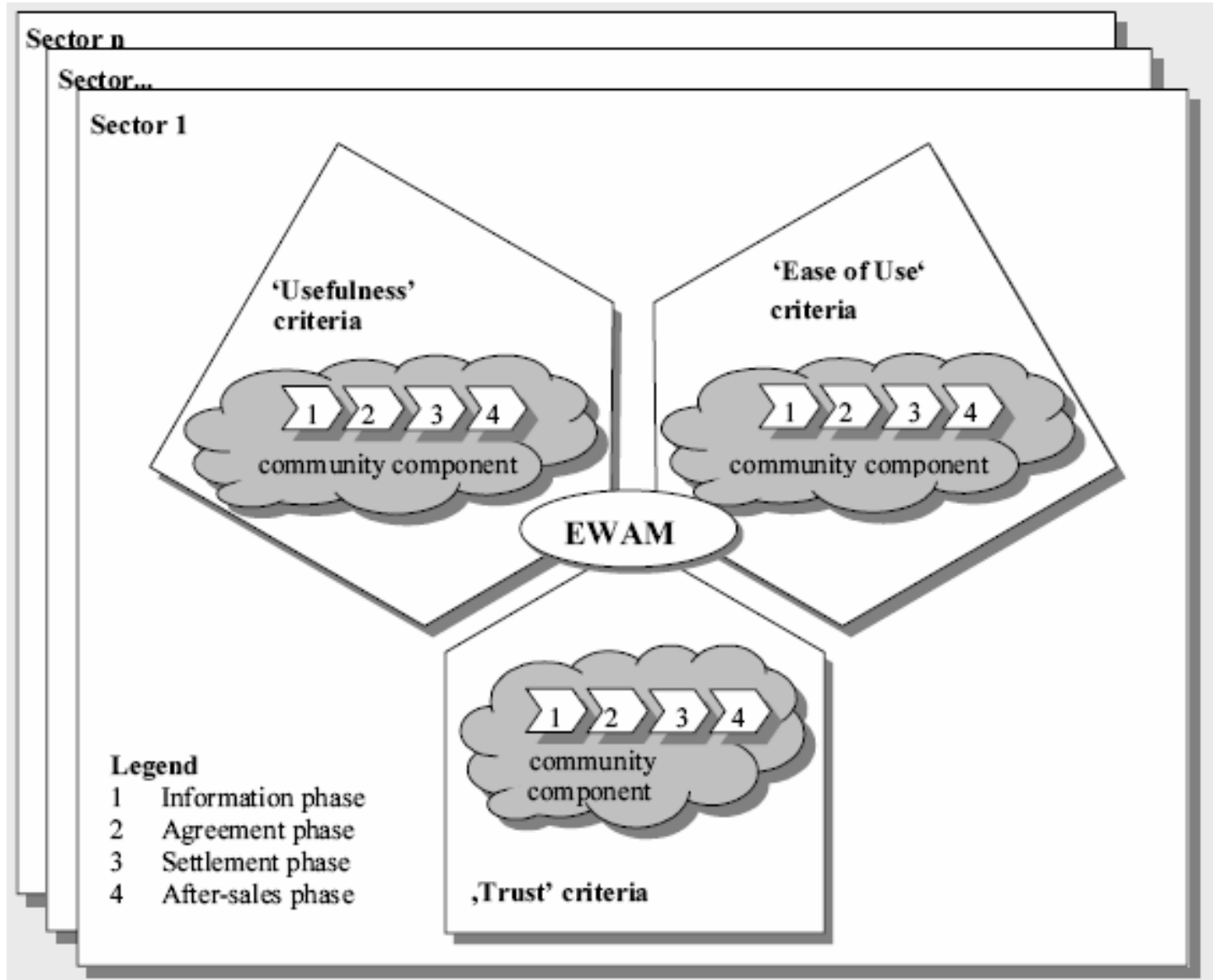

Gambar 2.8 Diagram Extended Web Assessment Method (EWAM)

Sumber: Schubert, 2003

\subsubsection{Peringkat Penting}

EWAM didasarkan kepada evaluasi ganda bagi setiap kriteria. Gambar 2.9 menunjukkan dua tahap penilaian. Tahap pertama, makna subyektif bagi sebuah atribut dideklarasikan oleh asesor. Penafsiran nilai "'" adalah sebagai berikut "Penting bagi sebuah situs web di dalam sektor ritel untuk ditemukan dengan mudah oleh pelanggan". Tahap kedua, evaluasi seluruh situs web di dalam sektor yang sama. Agregasi dari peringkat makna dari asesor adalah sebuah persyaratan pendahuluan yang penting untuk generasi hasil. Dalam kasus dimana peringkat maknanya adalah rendah ("--") nilai evaluasi aktual (tahap kedua) hampir tidak diperlukan lagi. 


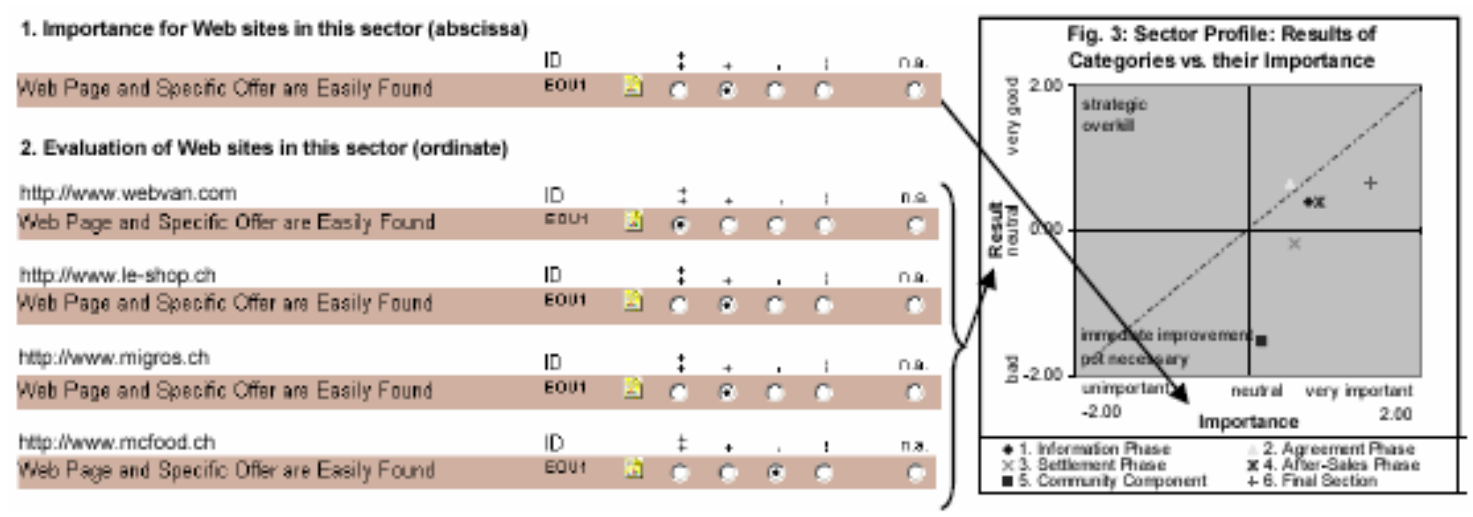

Gambar 2.9 Dua tahap penilaian: (1) Peringkat penting dan (2) Evaluasi situs web Sumber: Schubert, 2003

\subsubsection{Pengumpulan Data menggunakan EWAM Tool}

Data dikumpulkan melalui Internet dengan kuesioner online (EWAM tool). Kriteria individu ditetapkan kepada fase transaksi atau sebuah komponen komunitas, dan dua seksi baru ditambahkan ("After-Sales Phase" dan "Final Section” yaitu kriteria yang cocok dengan semua fase).

Ketika asesor (konsumen) mulai mengevaluasi dengan EWAM tool, tahap pertama asesor harus merekam Uniform Resource Locater (URL) dari situs web yang diuji dan menetapkan ke sektornya. Kemungkinan-kemungkinan pilihan skala diatur dimana asesor harus memutuskan sebuah pernyataan positif atau negatif dengan nilainya masing-masing. Skala memiliki empat nilai $(++,+,-,--)$. Alternatif nilai "n.a" (not applicable) bisa digunakan jika sebuah kriteria tidak relevan atau tidak tersedia dalam konteks tertentu. Kriteria diformulasikan dimana evaluasi positif (negatif) akan mengarah kepada hasil positif (negatif). "Saya sangat setuju" (+2), "Saya setuju" (+1), "Saya tidak setuju" (-1), "Saya sangat tidak setuju” (-2). "N.a." bernilai nol (0) artinya diabaikan untuk kalkulasi lebih lanjut. Lima skala tersebut juga diterapkan pada penelitian evaluasi situs web $e$ commerce yang dilakukan oleh Merwe \& Bekker (2003). 


\subsubsection{Analisis dan Persiapan Data}

Dalam studi ini data akan dianalisis berdasarkan hasil dari situs-situs web yang diuji. Situs web dibandingkan kepada rata-rata sektor, Best Practice Profile atau kepada kompetitor-kompetitornya dengan pertimbangan data diperoleh dari EWAM tool.

Berikut ini adalah tiga profil yang didefinisikan dalam EWAM (Schubert \& Dettling, 2002):

- Sector Profile: profil dari sektor yang relevan. Profil ini merupakan nilai rata-rata dari seluruh Company Profile yang diuji termasuk Best Sector Profile.

- Company Profile: profil situs web. Profil individual yang akan diuji, jika terdapat empat situs web yang akan dievaluasi berarti terdapat empat Company Profile.

- Best Practice Profile: profil yang terbaik dalam sektor yang relevan. Profil ini diperoleh dari hasil evaluasi dengan nilai tertinggi diantara profil-profil lainnya.

EWAM menilai sebuah situs web murni dari pandangan konsumen. Hasil EWAM terbaik bukan berarti bahwa situs web ini paling sukses dalam konteks finansial, karena kesuksesan dipengaruhi juga oleh faktor-faktor lain (misalnya relevansi ebusiness dari penawaran, keuntungan, aspek finansial dan lain-lain). Sebuah Best Practice Profile hanya bisa ditentukan ketika (a) terdapat jumlah yang cukup dari bisnis Internet yang berbeda per sektor yang telah dievaluasi dan (b) Kondisi ini telah dibandingkan dengan keberhasilan pelanggan mereka di dunia nyata. Oleh sebab itu, sebuah landasan referensi data Best Practice Profile yang sesuai hanya boleh terjadi dari dua kombinasi poin (a) dan (b).

\subsubsection{Laporan Penilaian Web Individu}

Hasil penilaian situs web adalah sebuah laporan penilaian individu yang berisi analisis-analisis dan representasi grafis sebagai berikut (Schubert, 2003): 
(a) Merangkum kriteria individu dan hasilnya pada kategori-kategori 1. Fase Informasi, 2. Fase Persetujuan, 3. Fase Penyelesaian, 4. Fase SetelahPenjualan, 5. Komponen Komunitas, 6. Bagian final, dan menghitung total nilai;

(b) Membandingkan situs web yang diuji dengan rata-rata sektor (Sector Profile), dan dengan Best Practice Profile dalam bentuk analisis kuantitatif dan grafis, tanpa melihat peringkat penting dari kriteria;

(c) Menggambarkan perbandingan hasil dari enam kategori-kategori pertama $(a, b)$ dengan peringkat penting kriteria bagi sebuah perusahaan dan profil sektornya;

(d) Membandingkan poin (b) diatas, tetapi dengan melihat peringkat penting kriteria.

\subsubsection{Strategi Umum EWAM}
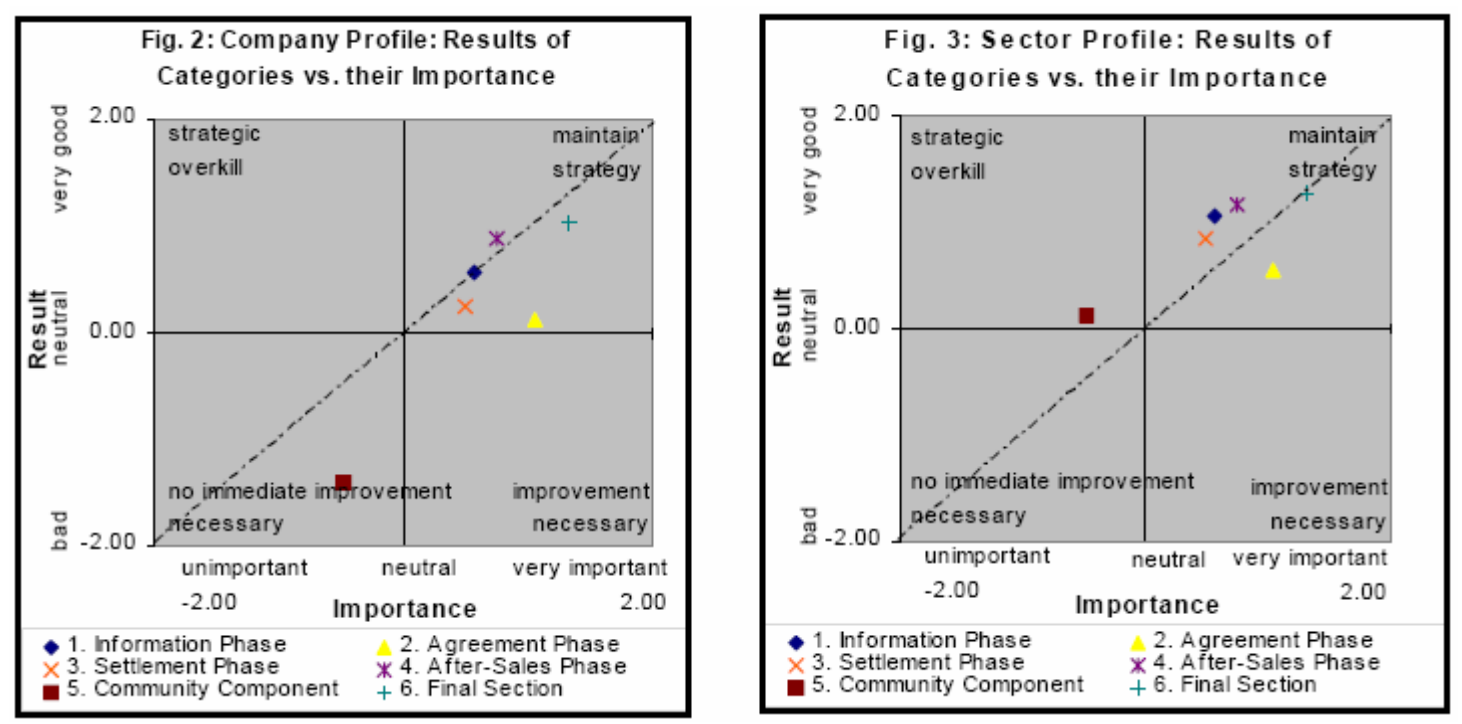

Gambar 2.10 Perbandingan hasil dari peringkat pentingnya kriteria Sumber: Schubert \& Dettling, 2002

Gambar 2.10 memperlihatkan perbandingan hasil-hasil dari kategori-kategori individu dengan peringkat makna bagi profil perusahaan dan sektor. Diperlihatkan dua matriks, kemudian dibagi lagi menjadi empat seksi dimana hasil dari setiap kategori seharusnya secara ideal berada pada garis atau di atas garis diagonal. 
Tabel 2.3 berikutnya berisi deskripsi rekomendasi-rekomendasi yang seharusnya diterapkan tergantung dari hasil bermacam-macam seksi.

Tabel 2.3 Evaluasi Strategi

\begin{tabular}{|l|l|}
\hline Strategi & Hasil \\
\hline Strategic Overkill & $\begin{array}{l}\text { Entri-entri pada bidang kiri atas mengindikasikan } \\
\text { hasil yang (sangat) baik dalam kategori-kategori } \\
\text { yang (kurang) tidak penting. Ketersediaan sumber- } \\
\text { sumber daya kemungkinan tidak dapat diterapkan } \\
\text { secara efektif }\end{array}$ \\
\hline Maintain Strategy & $\begin{array}{l}\text { Entri-entri pada bidang kanan atas mengindikasikan } \\
\text { hasil yang (sangat) baik dalam kategori-kategori } \\
\text { yang (sangat) penting }\end{array}$ \\
\hline $\begin{array}{l}\text { No improvement necessary } \\
\text { Improvi-entri pada bidang kiri bawah mengindikasikan } \\
\text { hasil yang (sangat) buruk dalam kategori-kategori } \\
\text { yang (kurang) tidak penting }\end{array}$ \\
\hline Improvement necessary & $\begin{array}{l}\text { Entri-entri pada bidang kanan bawah } \\
\text { mengindikasikan hasil yang (sangat) buruk dalam } \\
\text { kategori-kategori yang (sangat) penting }\end{array}$ \\
\hline
\end{tabular}

Sumber: Schubert, 2003

\subsubsection{Perumusan Matematika}

Paragraf berikut ini mendeskripsikan kalkulasi bagi perbandingan dari situs-situs web yang diuji dengan rata-rata dan dengan Best Practice Profile dari sektor, termasuk tingkat pentingnya kriteria, bagi Sector Profile. Kalkulasi bagi Company Profile dan Best Practice Profile adalah sama (Schubert, 2003).

Tabel 2.4 Kriteria $\mathrm{X}_{\mathrm{i}}$, Importance $\mathrm{W}_{\mathrm{i}}$ \& $\mathrm{Wg}_{\mathrm{i}}$, Evaluasi $\mathrm{r}_{\mathrm{i}}$, Weighted Value $\mathrm{R}_{\mathrm{i}}$

\begin{tabular}{|l|l|l|l|l|}
\hline Kriteria: $X_{i}$ & $\begin{array}{l}\text { Importance: } W_{i} \\
\text { (Jangkauan -2 /+2) }\end{array}$ & $\begin{array}{l}\text { Importance: } W g_{i} \\
\text { (Jangkauan 0- })\end{array}$ & $\begin{array}{l}\text { Evaluasi: } \overline{r_{i}} \\
(\text { Jangkauan -2 / +2) }\end{array}$ & $\begin{array}{l}\text { Weighted Value: } R_{i} \\
R_{i}=W g_{i} * \overline{r_{i}}\end{array}$ \\
\hline $\mathrm{X} 1$ & $\mathrm{~W}_{1}$ & $\mathrm{Wg}_{1}$ & $\overline{r_{1}}$ & $\mathrm{R}_{1}$ \\
\hline $\mathrm{X} 2$ & $\mathrm{~W}_{2}$ & $\mathrm{Wg}_{2}$ & $\overline{r_{2}}$ & $\mathrm{R}_{2}$ \\
\hline$\ldots$ & $\ldots$ & $\ldots$ & $\ldots$ & $\ldots$ \\
\hline $\mathrm{X} 26$ & $\mathrm{~W}_{26}$ & $\mathrm{Wg}_{26}$ & $\overline{r_{26}}$ & $\mathrm{R}_{26}$ \\
\hline
\end{tabular}




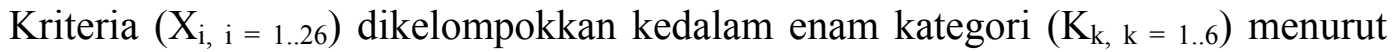
tiga fase transaksi (Information Phase, Agreement Phase, dan Settlement Phase), After-Sales Phase, Community Component, dan Final Section (lihat Tabel 2.4 dan Tabel 2.5).

Tabel 2.5 Kategori $\mathrm{K}_{1}-\mathrm{K}_{6}$

\begin{tabular}{|c|l|}
\hline Kategori $K_{k}$ & Deskripsi \\
\hline $\mathrm{K}_{1}$ & 1. Information Phase \\
\hline $\mathrm{K}_{2}$ & 2. Agreement Phase \\
\hline $\mathrm{K}_{3}$ & 3. Settlement Phase \\
\hline $\mathrm{K}_{4}$ & 4. After-Sales Phase \\
\hline $\mathrm{K}_{5}$ & 5. Community Component \\
\hline $\mathrm{K}_{6}$ & 6. Final Section \\
\hline
\end{tabular}

1. Transformasi dari peringkat penting sebuah kriteria

Evaluasi kriteria individual dan peringkat penting menggunakan skala dari (-2) sampai (+2). Untuk menghindari masalah terjadinya perkalian dua bilangan negatif, maka peringkat penting dari kriteria individu $\left(\mathrm{W}_{\mathrm{i}}\right)$ ditransformasikan kedalam jangkauan dari (0) sampai (1) $\left(\mathrm{Wg}_{\mathrm{i}}\right)$.

$\mathrm{Wg}_{\mathrm{i}}=\frac{1}{4}\left(W_{i}+2\right)$

2. Evaluasi rata-rata untuk setiap kriteria

$\overline{r_{i}}=\frac{1}{m} \sum_{j=1}^{m} r_{i j}$

dimana

$\mathrm{m}=$ jumlah asesor yang mengevaluasi sebuah kriteria $\mathrm{Xi}$

$\mathrm{R}_{\mathrm{ij}}=$ hasil individu dari sebuah kriteria di dalam jangkauan $(-2 /+2)$ 
3. Perkalian hasil rata-rata dengan peringkat penting

Hasil definitif bagi setiap kriteria muncul dengan mengalikan hasil rata-rata dari setiap kriteria $\left(\bar{r}_{i}\right)$ dengan peringkat pentingnya $\left(\mathrm{Wg}_{\mathrm{i}}\right)$. Sehingga kriteria hanya akan mencapai nilai tertinggi ketika peringkat pentingnya $\left(\mathrm{W}_{\mathrm{i}}=1\right)$ adalah tinggi. Dengan nilai peringkat penting yang lebih rendah $\left(1 \geq \mathrm{W}_{\mathrm{i}} \geq 0\right)$ hasil akhir dari kriteria akan menurun, namun tidak akan jatuh di bawah nol.

$$
\mathrm{Ri}=\overline{r_{i}} * \mathrm{Wg}_{\mathrm{i}}
$$

4. Penjumlahan evaluasi individual per kategori

Hasil untuk kategori $\left(K_{k, k=1.6}\right)$ tiba dengan menambahkan $R_{i}$ per kategori. Contoh pada Information Phase $\left(\mathrm{K}_{1}\right)$ dan Agreement Phase $\left(\mathrm{K}_{2}\right)$ diberikan di bawah ini:

$$
\begin{aligned}
\mathrm{K}_{1} & =\sum_{i=1}^{8} R_{i} \\
\mathrm{~K}_{2} & =\sum_{i=9}^{10} R_{i}
\end{aligned}
$$

5. Kalkulasi persentase pencapaian skor teratas dari $\mathrm{K}_{\mathrm{i}}$

a) Kalkulasi dari evaluasi minimum $\left(\mathrm{R}_{\mathrm{MINi}}\right)$ dan maksimum $\left(\mathrm{R}_{\mathrm{MAXi}}\right)$ untuk sebuah kriteria dengan peringkat penting di dalam jangkauan (0-1).

$$
\begin{array}{ll}
\mathrm{R}_{\mathrm{MINi}}=\mathrm{Wg}_{\mathrm{i}} *-2 & -2 \leq \mathrm{R}_{\mathrm{MINi}} \leq 0 \\
\mathrm{R}_{\mathrm{MAXi}}=\mathrm{Wg}_{\mathrm{i}} * 2 & 0 \leq \mathrm{R}_{\mathrm{MAXi}} \leq 2
\end{array}
$$

b) Kalkulasi dari evaluasi minimum $\left(\mathrm{R}_{\mathrm{MINi}}\right)$ dan maksimum $\left(\mathrm{R}_{\mathrm{MAXi}}\right)$ untuk sebuah kategori. Contoh yang diberikan untuk Information Phase $\left(\mathrm{K}_{\mathrm{k}, \mathrm{k}=1}\right)$.

$$
\begin{aligned}
& \mathrm{K}_{\mathrm{MIN} 1}=\sum_{i=1}^{8} R_{M I N i} \\
& \mathrm{~K}_{\mathrm{MAX} 1}=\sum_{i=1}^{8} R_{\text {MAXi }}
\end{aligned}
$$


c) Kalkulasi persentase pencapaian skor tertinggi

$$
\mathrm{K} \%{ }_{\mathrm{k}}=\frac{\left(K_{k}+K_{\text {MAXi }}\right)}{\left(K_{\text {MAXi }}+\left(K_{\text {MINi }} *-1\right)\right.} * 100 \%
$$

disederhanakan menjadi

$$
\mathrm{K} \% \mathrm{k}=0.5\left(\frac{K_{k}}{K_{M A X i}}+1\right) * 100 \%
$$

6. Transformasi $\mathrm{K} \%{ }_{\mathrm{k}}$ di dalam jangkauan $(-2 /+2)$

Dalam analogi-analogi yang lebih jauh hasil sebuah kategori $\left(\mathrm{K}_{\mathrm{k}}\right)$ seharusnya dibandingkan dengan peringkat pentingnya. Sebagai tambahan hasil $\mathrm{K} \% \mathrm{k}_{\mathrm{k}}$ ditransformasikan ke dalam jangkauan $(-2 /+2)$ sebagai hasil definitif dari kategori ini $\left(\mathrm{KR}_{\mathrm{k}}\right)$.

$$
\mathrm{KR}_{\mathrm{k}}=\left(\frac{K \%_{k}}{100} * 4\right)-2
$$

7. Perbandingan dari hasil kategori-kategori individual $(K R)$ dengan peringkat pentingnya.

Kalkulasi nilai rata-rata level penting dari kriteria individu $\left(\mathrm{W}_{\mathrm{i}}\right)$ untuk kategori tertentu $\left(\mathrm{K}_{\mathrm{k}}\right)$. Pada Fase Informasi sebagai contoh:

$$
\mathrm{KW}_{\mathrm{k}}=\frac{1}{8} \sum_{i=1}^{8} W_{i}
$$

\section{Skor Keseluruhan}

Skor keseluruhan adalah hasil final dari sebuah profil (PR). Skor ini dihitung dari jumlah enam kategori (KS) dalam keterhubungannya kepada hasil maksimum teoritis profilnya masing-masing.

a) Kalkulasi jumlah seluruh kategori (KS) 


$$
\mathrm{Ks}_{\mathrm{o}}=\sum_{k=1}^{6} K_{k}
$$

dimana o $(\mathrm{o}=1 . .3)$ merupakan indeks dari ketiga profil. (Sector Profile: $\mathrm{o}=1)$

b) Kalkulasi persentase pencapaian skor tertinggi KS

Kalkulasi yang sama dengan $5 \mathrm{c})$, namun seluruh kategori $(\mathrm{k}=1 . .6)$. Persentase pencapaian skor tertinggi dari $\mathrm{KS} \%_{0}$ dihitung dengan rumus berikut:

$$
\mathrm{KS} \%_{\mathrm{o}}=\frac{\left(K S_{o}+R S_{\text {MAXo }}\right)}{\left.R S_{\text {MAXo }}+R S_{\text {MINo }}-1\right)} * 100 \%
$$

\section{Dimana}

$\mathrm{RS}_{\text {MAXo }}=$ Skor maksimal teoritis dari seluruh kriteria dalam profil o

$\mathrm{RS}_{\mathrm{MINo}}=$ Skor minimal teoritis dari seluruh kriteria dalam profil o

disederhanakan menjadi:

$$
\mathrm{KS} \%_{\mathrm{O}}=0.5\left(\frac{K S_{o}}{R S_{\text {MAXo }}}+1\right) * 100 \%
$$

c) Transformasi dari $\mathrm{KS} \%_{0}$ di dalam jangkauan $(-2 /+2)$

$$
\mathrm{PR}_{\mathrm{o}}=\left(\frac{K S \%_{0}}{100} * 4\right)-2
$$

Sebagai contoh Sector Profile dengan nilai 1.02, berarti "baik" pada skala $(-2 /+2)$. Interpretasi yang relevan adalah: "Dalam sektor ini tampilan web dianggap baik di dalam rata-rata sektor".

Pada tesis ini, persamaan-persamaan $(2,1)$ sampai $(2,17)$ akan diterapkan untuk menghitung hasil evaluasi aplikasi e-commerce pada toko buku online berdasarkan peringkat penting kriteria. Seperti sudah diperlihatkan pada Gambar 2.9 bahwa terdapat dua tahapan evaluasi yaitu (1) evaluasi kriteria (peringkat penting) dan (2) evaluasi situs web. Hasil evaluasi dua tahap tersebut merupakan masukan untuk mengimplementasikan persamaan-persamaan $(2,1)$ sampai $(2,17)$, hasil perhitungan yang diperoleh merupakan keluaran yang kemudian menjadi 
dasar bagi peneliti untuk melakukan analisis lebih jauh evaluasi situs web berdasarkan peringkat penting pada BAB 5 . Detail penerapan persamaan $(2,1)$ sampai $(2,17)$ dapat dilihat pada Lampiran 9 halaman 171-176. 


\section{BAB 3 \\ METODOLOGI PENELITIAN}

Bab ini menguraikan langkah-langkah pelaksanaan penelitian yang dapat diuraikan sebagai berikut: desain penelitian, metode penelitian, strategi penelitian, penentuan asesor dan situs web yang diuji, metode pengumpulan data, dan analisis data.

\subsection{Desain Riset}

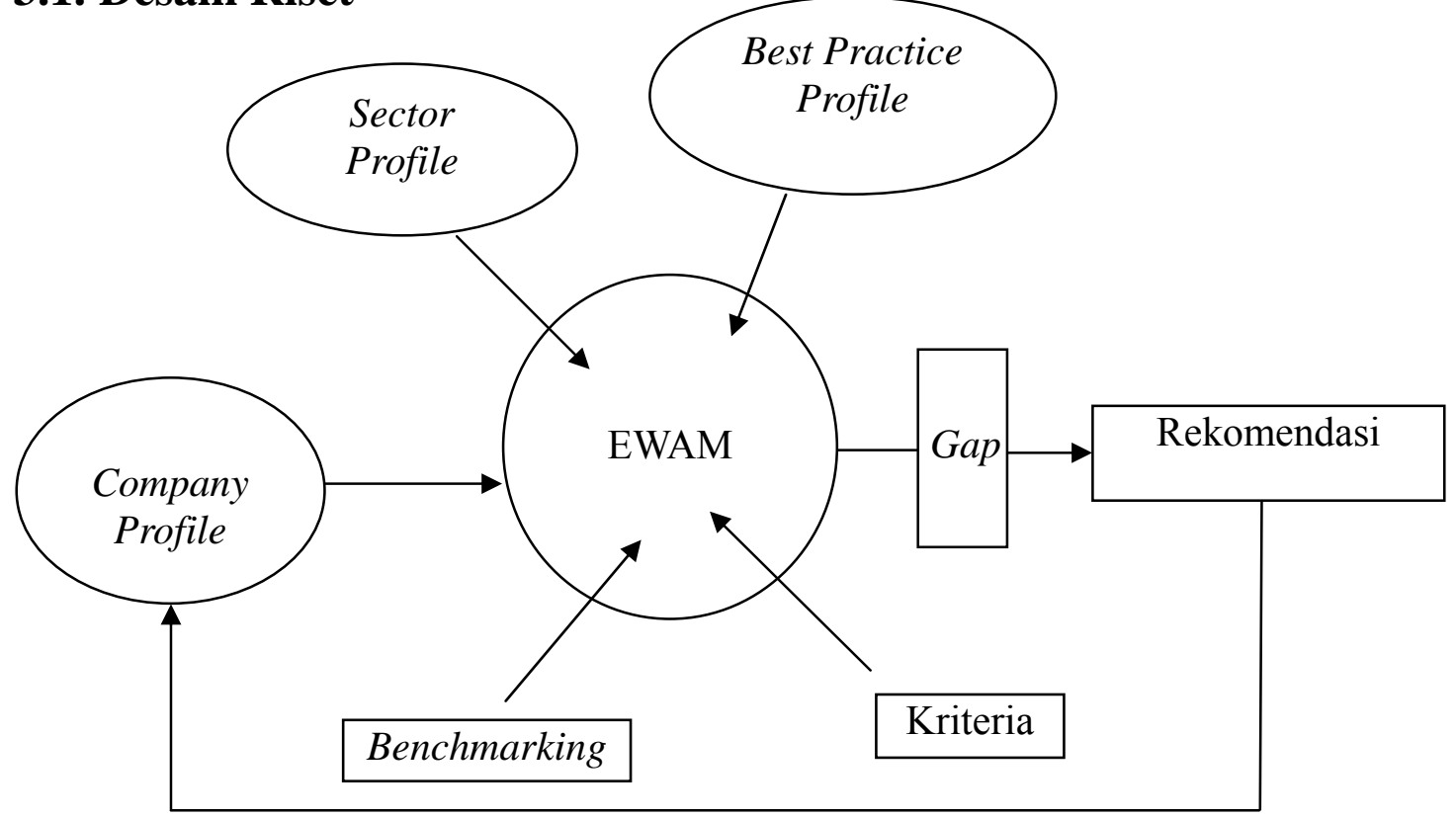

Gambar 3.1 Desain Riset Evaluasi Aplikasi E-Commerce dengan EWAM

Desain riset pada Gambar 3.1 mengilustrasikan kerangka konseptual terkait dengan penelitian evaluasi aplikasi e-commerce menggunakan Extended Web Assessment Method (EWAM)

Penilaian situs web dengan metode EWAM mengevaluasi tiga variabel yaitu Usefulness, Ease of Use, dan Trust. Ketiga variabel ini dipecah menjadi 26 kriteria dan dikelompokkan kepada fase-fase transaksi elektronik yaitu Information Phase, Agreement Phase, Settlement Phase, After-Sales Phase dan ditambah dengan Community Component dan Final Section. 
Setiap situs web (Company Profile) akan dievaluasi dan hasil penilaiannya akan dibandingkan dengan Best Practice Profile (situs web dengan skor tertinggi) dan Sector Profile (nilai rata-rata dari seluruh situs web yang diuji).

Gap akan ditemukan dari hasil perbandingan profil diatas, apabila hasil evaluasi ditemukan di bawah dari Best Practice Profile dan kurang sesuai dengan ekspektasi konsumen (hasil evaluasi kriteria), maka rekomendasi diperlukan untuk memperbaiki nilai dari kriteria-kriteria tersebut.

\subsection{Metode Riset}

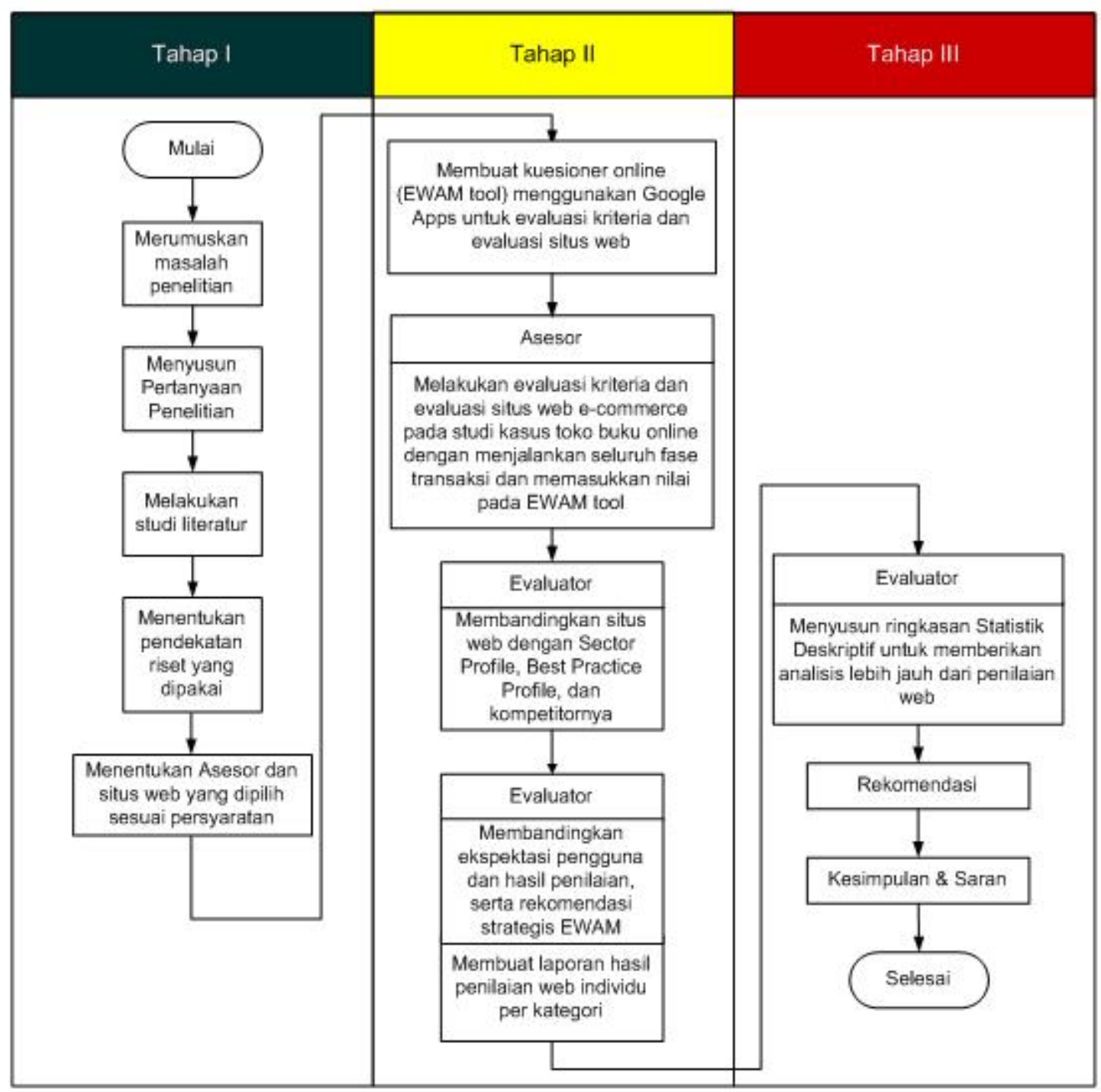

Gambar 3.2 Tahap-tahap pelaksanaan penelitian yang akan dilakukan 
Penelitian ini dilaksanakan melalui tiga tahap seperti terlihat pada Gambar 3.2 yaitu

- Tahap I: Merumuskan masalah yang akan diteliti; melakukan studi literatur terkait dengan aspek-aspek yang akan diteliti terdiri dari: Kondisi ICT di Indonesia, definisi e-commerce, penerapan e-commerce di Indonesia, pendekatan penelitian yang digunakan dan teori dasar EWAM meliputi fase-fase transaksi dalam pasar elektronik, kriteria evaluasi, dan TAM dan TRA; menentukan jumlah asesor (konsumen) yang akan menilai dan menentukan situs web yang akan dievaluasi.

- Tahap II: Membuat instrumen kuesioner secara online terdiri dari formulir evaluasi kriteria dan formulir evaluasi situs web dari EWAM tool yang dibuat menggunakan Google Apps. Selanjutnya setiap asesor akan melakukan dua penilaian yaitu evaluasi situs web dan evaluasi kriteria melalui EWAM tool, setelah seluruh asesor melakukan penilaian, maka evaluator (peneliti) akan mengambil data tersebut dari Google Docs dan siap melakukan tahap analisis sesuai metode EWAM.

- Tahap III: Tahap terakhir yaitu hasil analisis telah diperoleh, dilanjutkan dengan membuat kesimpulan dan saran.

\subsection{Strategi Riset}

Jenis strategi riset yang digunakan dikaitkan dengan bagaimana pertanyaan riset diposisikan. Tabel 3.1 memperlihatkan lima strategi riset yang berbeda yang digunakan dalam penelitian Ilmu Sosial.

Tabel 3.1 Perbedaan strategi riset

\begin{tabular}{|l|l|}
\hline Strategi Riset & Bentuk-bentuk Pertanyaan Riset \\
\hline Eksperimen & How/Why \\
\hline Survei & Who/What/Where/How many/How much \\
\hline Archival/Analisis & Who/What/Where/How many/How much \\
\hline History & How/Why \\
\hline Studi-studi Kasus & How/Why \\
\hline
\end{tabular}

Sumber: Diadaptasi dari Yin, 2003, pp. 5 
Yin (2003) mengindikasikan bahwa studi-studi kasus dipakai untuk membawa kepada pengertian yang lebih mendalam, pemahaman, dan pengetahuan tentang kasus tertentu yang dipilih.

Denscombe pada tahun 2000 (Eshun \& Taylor, 2009) menyatakan pendekatan studi kasus memungkinkan peneliti membuat pilihan antara sejumlah kemungkinan kejadian, orang, dan organisasi. Ia lebih jauh menekankan bahwa peneliti bisa mengambil satu atau hanya beberapa dari banyak sampel dari sekelompok hal-hal yang dipelajari.

Perbedaan strategi riset yang dijelaskan pada Tabel 3.1 oleh Yin (2003) juga relevan untuk Ilmu-ilmu Eksakta. Peneliti mengadaptasi strategi riset "Studi Kasus" yang menurut peneliti sangat tepat dipilih pada tesis ini untuk diterapkan bersama metode EWAM yang menggunakan pendekatan kuantitatif.

Strategi riset studi kasus juga dipertimbangkan paling tepat dan cocok untuk tesis ini sesuai dengan penetapan evaluasi situs web per sektor. Hal ini berkaitan dengan fakta (Eshun \& Taylor, 2009) bahwa studi kasus memungkinkan bagi peneliti untuk menggali pengertian dan sebuah pemahaman mendalam terkait penelitian yang dilakukan pada tesis ini yaitu evaluasi aplikasi e-commerce pada toko buku online di Indonesia yang diwujudkan juga pada analisis kualitatif pada metode EWAM.

\subsection{Penentuan Asesor dan Situs Web yang Diuji}

Pada tesis ini, penentuan jumlah asesor dan situs web didasarkan pada hasil penelitian sebelumnya seperti terlihat pada Tabel 3.2. 
Tabel 3.2 Metode EWAM yang digunakan pada riset sebelumnya

\begin{tabular}{|c|c|c|c|c|}
\hline No. & Sektor & Situs web & Jumlah asesor & Referensi \\
\hline 1 & $\begin{array}{l}\text { Consumer } \\
\text { goods }\end{array}$ & $\begin{array}{l}\text { Swiss } \\
\text { http://www.webvan.com (Best Practice) } \\
\text { http://www.le-shop.ch } \\
\text { http://www.migros.ch } \\
\text { http://www.mcfood.ch }\end{array}$ & 20 orang & $\begin{array}{l}\text { Schubert \& } \\
\text { Leimstoll (2001) }\end{array}$ \\
\hline 2 & Grocery & $\begin{array}{l}\text { Swiss } \\
\text { http://www.shop.coop.ch } \\
\text { http://www.leshop.ch } \\
\text { http://www.migros-shop.ch (Best Practice) } \\
\text { http://www.spar.ch } \\
\text { Australia } \\
\text { http://www.homeshop.com.au } \\
\text { http://www.groceries4u.com.au } \\
\text { http://www.greengrocer.com.au } \\
\text { http://www.aussieshopper.com.au } \\
\text { http://www.shopfast.com.au } \\
\text { http://www.colesonline.com.au (Best } \\
\text { Practice) }\end{array}$ & $\begin{array}{l}25 \text { orang (seluruh } \\
\text { situs web) } \\
80 \text { orang (seluruh } \\
\text { situs web) } \\
\text { Jumlah respons } \\
\text { dari asesor 5-56 } \\
\text { orang }\end{array}$ & $\begin{array}{l}\text { Leimstoll, Kurnia, } \\
\text { \& Schubert } \\
(2005 b)\end{array}$ \\
\hline 3 & $\begin{array}{l}\text { Selling } \\
\text { books online }\end{array}$ & $\begin{array}{l}\text { Australia } \\
\text { Angus \& Robertson } \\
\text { Dymocks } \\
\text { Booktopia (Best Practice) } \\
\text { McGills } \\
\text { QBD The Book Shop } \\
\text { Reader's Refuge } \\
\text { Technical Book Shop } \\
\text { Swiss } \\
\text { Amazon (Best Practice) } \\
\text { Bider \& Tanner } \\
\text { Books } \\
\text { Buch } \\
\text { Jaeggi }\end{array}$ & $\begin{array}{l}14 \text { orang } \\
9 \text { orang } \\
31 \text { orang } \\
8 \text { orang } \\
17 \text { orang } \\
12 \text { orang } \\
12 \text { orang } \\
\\
15 \text { orang } \\
14 \text { orang } \\
13 \text { orang } \\
16 \text { orang } \\
16 \text { orang }\end{array}$ & $\begin{array}{l}\text { Leimstoll, Kurnia, } \\
\text { \& Schubert } \\
\text { (2005a) }\end{array}$ \\
\hline 4 & Any Sector & $\geq 3$ dan $\leq 7$ & 10 orang & Leimstoll (2009) \\
\hline 5 & $\begin{array}{l}\text { Selling } \\
\text { books online }\end{array}$ & $\begin{array}{l}\text { Indonesia } \\
\text { http://amazon.com (Standar De Facto) } \\
\text { http://balaipustakaonline.com } \\
\text { http://erlangga.co.id } \\
\text { http:/gramediaonline.com } \\
\text { http://kutukutubuku.com }\end{array}$ & 20 orang & $\begin{array}{l}\text { Riset yang sedang } \\
\text { dilakukan (2010) }\end{array}$ \\
\hline
\end{tabular}

Sumber: Hasil kompilasi sendiri dari Schubert \& Leimstoll, 2001; \& Leimstoll, Kurnia \& Schubert 2005a \& 2005b; Leimstoll, 2009. 
Penentuan situs web dipilih berdasarkan persyaratan berikut:

- Toko buku online sebagai situs web profil yang memiliki setidaknya fase transaksi dalam pasar elektronik yaitu Fase Informasi (Information Phase), Fase Kesepakatan (Agreement Phase), dan Fase Penyelesaian (Settlement Phase).

- Toko buku online tersebut memiliki nama domain sendiri dan berada di wilayah Indonesia.

- Bukan organisasi non profit dan bukan berupa blog, situs web profil hanya menjual buku saja baik tercetak atau e-book untuk menghindari adanya bias antar sektor.

Jumlah situs web yang diuji adalah empat toko buku online yang berada di Indonesia sebagai situs web profil (Company Profile), sedangkan amazon.com dalam penelitian ini dijadikan sebagai Standar De Facto.

Dalam penentuan asesor terdapat sejumlah persyaratan yang harus dipenuhi oleh asesor untuk dapat melaksanakan penilaian web menggunakan EWAM tool (Leimstoll, Kurnia, \& Schubert, 2005a):

- Mereka harus memahami secara penuh kriteria dari formulir penilaian web dan harus diinstruksikan secara menyeluruh.

- Mereka harus merupakan pengguna-pengguna web yang berpengalaman.

- Mereka harus menyediakan waktu untuk melewati empat fase transaksi secara utuh dari setiap situs web yang dinilai (termasuk pengiriman dan pembayaran).

Berdasarkan kriteria pemilihan asesor di atas (Leimstoll, Kurnia, \& Schubert, 2005a), maka peneliti mengambil sebanyak 20 orang asesor yang terdiri dari 17 asesor dari mahasiswa tingkat akhir di Magister Teknologi Informasi (MTI-UI), Fakultas Ilmu Komputer, Universitas Indonesia; 2 orang terdiri dari staf pengajar dan praktisi di bidang Ilmu Komputer dari institusi yang berbeda; dan 1 orang lagi mahasiswa tingkat akhir program pascasarjana Universitas Gunadarma. Seluruh asesor pernah melakukan transaksi online dan mereka sudah memiliki cukup 
pengalaman dalam dunia Internet ditunjukkan dari pengalaman lebih dari 4 tahun. Instruksi kepada asesor secara menyeluruh berkaitan dengan proses evaluasi kriteria dan evaluasi situs web dilakukan melalui EWAM tool, jadi instruksi tidak dilakukan melalui pertemuan secara face-to-face.

Tesis ini menggunakan EWAM sebagai metode evaluasi aplikasi e-commerce dari perspektif konsumen, sehingga situs web profil akan dinilai oleh konsumen (asesor dalam konteks EWAM). Bagaimanapun juga, EWAM tool adalah sebuah proses yang membutuhkan pengetahuan yang tinggi, sehingga peneliti tidak bisa mengambil sampel secara acak dari konsumen yang akan melakukan penilaian.

\subsection{Metode Pengumpulan Data}

Dalam studi ini peneliti menggunakan informasi yang didapat dari hasil penilaian asesor melalui EWAM tool sebagai sumber data yang dikumpulkan. EWAM tool adalah instrumen kuesioner yang terdiri dari kriteria-kriteria yag dibuat berdasarkan ekspektasi konsumen dan karakteristik media inheren. Asesor menilai sebuah situs web berdasarkan kriteria-kriteria tersebut secara online. EWAM tool dalam tesis ini dibuat menggunakan aplikasi berbasis web Google Apps.

\subsection{Analisis Data}

Dalam studi ini data akan dianalisis berdasarkan hasil situs web yang diuji. Situs web (Company Profile) dibandingkan kepada rata-rata sektor (Sector Profile), profil terbaik (Best Practice Profile) atau kepada kompetitor-kompetitornya setelah data diperoleh dari EWAM tool.

Tiga profil yang didefinisikan dalam EWAM terdiri dari (Schubert \& Dettling, 2002):

- Sector Profile: profil dari sektor yang relevan. Profil ini diperoleh dari nilai rata-rata hasil evaluasi situs web. Misalnya dalam riset ini dipilih empat situs web toko buku online, maka Sector Profile merupakan nilai rata-rata dari empat situs web tersebut. 
- Company Profile: profil situs web. Situs web individu yang dinilai adalah merupakan Company Profile. Riset ini mengevaluasi empat situs web dengan aplikasi e-commerce artinya terdapat empat Company Profile yang dinilai.

- Best Practice Profile: profil terbaik dalam sektor yang relevan. Sebuah situs web yang memperoleh nilai tertinggi dari hasil evaluasi akan menjadi Best Practice Profile.

Hasil penilaian situs web adalah sebuah laporan penilaian individu yang berisi analisis-analisis dan representasi grafis sebagai berikut (Schubert, 2002-2003):

1. Merangkum kriteria individu dan hasilnya dalam kategori-kategori Fase Informasi, Fase Persetujuan, Fase Penyelesaian, Fase Setelah-Penjualan, Komponen Komunitas, Bagian Final, dan menghitung total nilai;

2. Membandingkan situs web yang diuji (Company Profile) dengan rata-rata sektor (Sector Profile) dan dengan profil terbaik (Best Practice Profile) dalam bentuk analisis kuantitatif dan grafis tanpa melihat dari peringkat penting kriteria.

3. Menggambarkan perbandingan hasil dari enam kategori-kategori pertama $(1,2)$ dengan peringkat penting kriteria bagi sebuah perusahaan dan profil sektornya;

4. Membandingkan poin (2) di atas, tetapi dengan melihat peringkat penting kriteria.

Dalam konteks Tesis ini empat situs web lokal toko buku online di Indonesia dipilih untuk dievaluasi dan satu situs web internasional amazon.com sebagai Standar De Facto. Secara praktis proses evaluasi dilakukan kepada situs web lokal dan internasional, namun proses perbandingan poin (1-4) di atas hanya relevan diterapkan untuk empat situs web lokal yang berada di Indonesia. Pertimbangan peneliti melakukan langkah ini adalah karena amazon.com merupakan situs web yang berada di wilayah Amerika Serikat sehingga berbeda secara geografis dan aturan hukum transaksi elektronik. Secara praktis (De Facto) amazon.com telah berhasil menerapkan aplikasi e-commerce penjualan buku online di seluruh dunia, 
artinya konsumen juga berada di berbagai belahan dunia. Sedangkan empat situs web toko buku online yang dinilai menerapkan aplikasi e-commerce hanya untuk pasar lokal yaitu konsumen yang berada di Indonesia. Pertimbangan lain yang juga penting adalah peneliti belum menelusuri lebih jauh apakah amazon.com juga menjual buku-buku dari penerbit di Indonesia. 


\section{BAB 4 \\ PROFIL ORGANISASI}

Bab ini membahas profil empat toko buku online lokal dan profil amazon.com sebagai situs web Standar De Facto yang akan dinilai implementasi aplikasi $e$ commerce kepada situs-situs webnya.

\subsection{Situs Web 1: Toko Buku Gramedia (www.gramediaonline.com)}

\subsubsection{Latar Belakang}

Tak bisa dipungkiri bahwa distribusi merupakan mata rantai yang lemah dalam dunia bisnis di Indonesia. Penerbit dan percetakan saja tidaklah cukup untuk dapat mendistribusikan produk secara merata ke seluruh pelosok tanah air. Itulah sebabnya Kelompok Kompas Gramedia (KKG) mendirikan jaringan toko buku, dengan maksud memperkuat penyebaran produk, tanpa berkeinginan untuk lepas dari jaringan distribusi yang ada.

Toko Buku Gramedia didirikan 2 Februari 1970 oleh P.K. Ojong yang juga merupakan pendiri KKG, dengan misi turut serta menyebarkan produk pendidikan dan informasi, demi tercapainya cita-cita bersama mencerdaskan kehidupan bangsa, menuju masyarakat baru Indonesia yang berkehidupan Pancasila.

Dari sebuah toko buku kecil berukuran $25 \mathrm{~m}^{2}$, yang berlokasi di Jalan Gajah Mada, Jakarta Barat, Toko Buku Gramedia sampai tahun 2002 telah tumbuh dan berkembang menjadi 50 toko, yang tersebar di beberapa kota utama di Indonesia. Mengantisipasi perkembangan ilmu dan teknologi, Toko Buku Gramedia membentuk Gramedia Online.

\subsubsection{Misi}

Misi dari Toko Buku Gramedia adalah ikut serta dalam upaya mencerdaskan bangsa dengan menyebarluaskan pengetahuan dan informasi melalui berbagai sarana usaha ritel dan distribusi buku, alat sekolah, dan kantor serta produk 
multimedia, ditandai dengan pelayanan unggul, manajemen proaktif, dan perilaku bisnis yang sehat.

\subsubsection{Ragam Produk dan Dukungan Pemasok}

Semula pada saat berdiri Toko Buku Gramedia hanya menawarkan buku namun saat ini ragam produknya sudah semakin berkembang antara lain: peralatan kantor, peralatan olah raga, dan produk seperti $C D-R O M$, audio-video book, dan berbagai produk lain. Pemasaran produk tersebut didukung oleh ratusan penerbit dan pemasok dalam dan luar negeri, termasuk beberapa penerbit internal KKG sendiri seperti: Gramedia Pustaka Utama, Elex Media Komputindo, Gramedia Widya Sarana, Bhuana Ilmu Populer, dan Penerbit Gramedia Majalah.

\subsubsection{Departemen Impor}

Departemen Impor bertugas khusus untuk mengelola dan mengembangkan jalinan kerja sama dengan penerbit luar negeri yang kini berjumlah lebih dari 250 penerbit. Berikut ini penerbit luar negeri yang aktif menjalin kerjasama:

- Amerika Serikat: Simon \& Schuster, Prentice Hall, McGraw Hill, Maxwell Macmillan, Addison Wesley, John Wiley, Harper Collins, Bantam, Random House, dan Baker \& Taylor.

- Eropa: Penguin, Cambridge, Oxford, Elsevier, Grossohaus, Hachette, Longman, dan MacMillan UK.

- Asia: Kondasha, Japan Publication, Toppan, Canfonian, Asiapac, UBSPD, S. Chand, S.S. Mubaruk, Pan Pacific, Mighty Mind, dan Federal Publication.

Toko buku Gramedia adalah merupakan toko buku fisik yang besar di Indonesia dan telah memiliki citra yang baik sebagai toko buku yang sangat lengkap, sehingga penulis tertarik mengambil divisi penjualan buku online perusahaan ini untuk diteliti. 


\subsection{Situs Web 2: Penerbit Erlangga (www.erlangga.co.id)}

\subsubsection{Latar Belakang}

Penerbit Erlangga hadir pada tahun 1952, di tengah keprihatinan kondisi pendidikan nasional, saat para siswa Indonesia kesulitan memperoleh buku-buku untuk belajar. Keprihatinan ini memberikan motivasi Penerbit Erlangga untuk berkarya dengan melahirkan banyak buku. Tujuannya adalah ikut berpartisipasi dalam peningkatan kualitas pendidikan dengan menerbitkan buku-buku bermutu, mulai dari tingkat prasekolah, TK, sekolah dasar, sekolah menengah, perguruan tinggi, dan kalangan profesional.

- Pra sekolah: bidang ini baru dimulai dan akan terbit sekitar 100 judul buku.

- Sekolah dasar: lebih dari seratus judul buku telah diterbitkan mencakup buku teks, soal, dan keterampilan.

- Sekolah menengah: lebih dari dua ratus judul buku telah diterbitkan, mencakup buku teks, soal, dan persiapan masuk ke perguruan tinggi.

- Perguruan tinggi: lebih dari seribu judul telah diterbitkan mencakup semua bidang seperti ekonomi, teknik, MIPA, dan sosial.

- Umum: lebih dari empat ratus judul telah diterbitkan mencakup buku popular, pengembangan diri, dan religius.

\subsubsection{Visi}

Visi dari Penerbit Erlangga adalah menjadi mitra utama bagi semua pihak yang berkepentingan dalam memajukan dan meningkatkan kualitas sumber daya manusia Indonesia, agar mampu bersaing dengan bangsa-bangsa maju di dunia, khususnya dalam penguasaan ilmu pengetahuan yang akan dicapai melalui kepemimpinan di setiap segmen.

\subsubsection{Misi}

- Memberi solusi kepada setiap orang yang menghadapi masalah dalam mencari dan mengejar ilmu pengetahuan. 
- Menyediakan produk dan layanan yang memenuhi standar tertinggi, jauh di atas para pesaing yang ada dalam industri perbukuan.

- Memastikan bahwa semua pihak yang berhubungan dengan Penerbit Erlangga dapat merasakan dan menerima manfaat.

- Menghasilkan tingkat pengembalian yang wajar atas risiko modal dan investasi yang dihadapi oleh para pemegang saham, meningkatkan kekayaan perusahaan, dan menjadi sumber kemakmuran bagi orang-orang yang bekerja di penerbit ini.

- Sumber daya manusia merupakan unsur strategis yang sangat menentukan arah dan masa depan dari bisnis. Oleh karena itu, perusahaan akan memberdayakan dan memotivasi orang-orang yang bekerja agar memberikan potensi produktivitas dan kreativitas terbaik yang dimiliki secara berkesinambungan.

\subsubsection{Kelompok Erlangga}

Kelompok Erlangga terdiri dari:

- Erlangga (www.erlangga.co.id)

- Esis (www.esisforum.com)

- Erlangga For Kids

- Esensi

- Phibeta

- GAP

- Eureka

Meskipun tidak sebesar Gramedia, keberadaan Penerbit Erlangga sangat dibutuhkan terutama pada pangsa pasar anak sekolah. Penerbit ini memiliki komitmen untuk memberikan dukungan terhadap terbitnya buku-buku pelajaran sekolah dari tingkat dasar sampai ke perguruan tinggi. Sejak berdiri tahun 1952 Penerbit Erlangga terus berkembang dan mampu bertahan dari persaingan. Kondisi ini menunjukkan strategi perusahaan telah direncanakan dan dijalankan secara baik, sehingga atas dasar itulah peneliti memilih situs web penjualan buku online penerbit ini untuk dievaluasi. 


\subsection{Situs Web 3: PT. Balai Pustaka (www.balaipustakaonline.com)}

\subsubsection{Dasar Hukum}

Didirikan berdasarkan Peraturan Pemerintah Nomor 66 Tahun 1996 tentang pengalihan bentuk Perusahaan Umum (Perum) Penerbitan dan Percetakan Balai Pustaka menjadi Perusahaan Perseroan (Persero) Penerbitan dan Percetakan Balai Pustaka, yang kemudian dikukuhkan melalui Akta Notaris Pendirian Perusahaan Perseroan Penerbitan dan Percetakan Balai Pustaka tertanggal 30 Desember 1996 oleh Notaris Chufran Hamal, SH. di Jakarta, dan disahkan oleh Menteri Kehakiman melalui Keputusan Nomor C2-1820HT.01.01 Tahun 1997 tanggal 17 Maret 1997.

\subsubsection{Strategi Umum}

- Efisiensi, efektivitas, dan produktivitas penyelenggaraan seluruh mata rantai kegiatan operasional perusahaan, sehingga pada gilirannya dapat mempertahankan kinerja perusahaan pada tingkat simplifikasi dalam penyelenggaraan manajemen perusahaan.

- Memantau, mengamati, dan mencermati setiap kebijakan pemerintah di bidang pendidikan, antara lain kemungkinan perubahan kurikulum pendidikan.

- Melaksanakan restrukturisasi di berbagai bidang dalam rangka peningkatan efisiensi dan efektivitas penyelenggaraan manajemen perusahaan.

- Mengembangkan jaringan kerja sama dengan penerbitan dan percetakan luar negeri sebagai langkah awal memasuki pasar global.

\subsubsection{Tujuan}

Tujuan dari PT. Balai Pustaka adalah turut melaksanakan dan menunjang kebijakan dan program pemerintah di bidang ekonomi dan pembangunan nasional pada umumnya, khususnya di bidang perbukuan dan multimedia pendidikan dengan menerapkan prinsip-prinsip Perseroan Terbatas. 


\subsubsection{Visi}

Visi dari PT. Balai Pustaka adalah menjadi salah satu perusahaan yang tangguh dalam bidang Industri Grafika/Industri Informasi.

\subsubsection{Misi}

PT. Balai Pustaka memiliki beberapa misi yang diuraikan sebagai berikut:

Misi Nasional: Membantu meningkatkan ketahanan nasional melalui upaya mencerdaskan kehidupan bangsa.

Misi Budaya: Ikut berperan dalam proses pencerdasan kehidupan bangsa melalui penerbitan dan pemasyarakatan naskah-naskah dalam wujud buku dan multimedia pendidikan, serta memelihara dan mengembangkan naskah nostalgia dan modern.

Misi Ekonomi: Memperoleh keuntungan ekonomi untuk membantu mempertahankan kemampuan ekonomi nasional, serta mempertahankan kinerja perusahaan dengan klasifikasi sehat dan kualifikasi wajar tanpa pengecualian.

Misi Sosial: Membantu masyarakat untuk memperoleh bahan bacaan yang bermutu dengan harga yang terjangkau dan membantu perusahaan-perusahaan yang lemah termasuk perusahaan sejenis.

Penerbit Balai Pustaka sangat terkenal dengan komitmennya menerbitkan bukubuku sastra dari karya-karya sastrawan-sastrawan lokal yang akhirnya menjadi dikenal oleh masyarakat Indonesia. Buku terbitannya banyak menjadi karya-karya monumental seperti Layar terkembang Karya Sultan Takdir Alisjahbana, Siti Nurbaya Karya Marah Rusli, Tenggelamnya Kapal Van Der Wijck Karya HAMKA, dan lain-lain. Penerbit ini sangat besar jasanya dalam mendokumentasikan karya-karya sastra anak bangsa. Saat mengunjungi situs web perusahaan ini, ditemukan tiga fase transaksi pasar elektronika, sehingga peneliti memutuskan untuk menjadikan salah satu situs web yang akan dievaluasi. 


\subsection{Situs Web 4: Kutukutubuku (www.kutukutubuku.com)}

Pendirinya adalah dua remaja putri dengan nama panggilan Ollie dan Angel yang lulus dari sebuah perguruan tinggi swasta di Jakarta. Berawal dari kesukaan mereka mengumpulkan buku dan juga menulis buku (Ollie) jadilah mereka sebagai entrepreneur muda. Berbeda dengan Penerbit Gramedia, Erlangga, dan Balai Pustaka yang merupakan penerbit sekaligus penjual bukunya sendiri (kecuali Gramedia yang menjual juga buku-buku dari penerbit lain), Kutukutubuku.com murni hanya menjual saja buku-buku dari penerbit. Kutukutubuku.com menjalankan bisnis penjualan bukunya murni secara online. Dengan mengunjungi situs webnya banyak terlihat keseragaman dan komitmen dalam menunjukkan identitasnya. Wujud kutu bersayap warna merah dihiasi lingkaran-lingkaran hitam sudah menjadi ciri khasnya. Peneliti tertarik untuk meneliti lebih lanjut aplikasi e-commerce pada situs web berwarna merah ini karena kutukutubuku sudah cukup dikenal luas oleh masyarakat dan kutukutubuku menjual produk bukunya murni secara online.

\subsection{Situs Web 5: Toko Buku Amazon (www.amazon.com)}

Amazon menyediakan sebuah kasus unik untuk mengilustrasikan bagaimana Internet dengan sebenarnya mengubah cara konsumen membeli dan menjual produk-produk dan servis-servisnya. Kasus Amazon didokumentasikan secara baik (Economist 1997; Kotha 1998 dikutip di dalam Schubert \& Selz, 2001). Tahun 1999, Amazon sudah berhasil menjual buku-bukunya seharga 600 juta dollar (Economist 1999 dikutip di dalam Schubert \& Selz, 2001). Saat ini, Amazon mulai menjual video, musik, permainan, dan memulai situs web yang baru untuk fasilitas lelang online seperti eBay.

Amazon berbeda dari toko-toko buku yang menjual secara fisik. Pelangganpelanggan dapat mencari katalog online yang berisi lebih dari 2,5 juta buku, sekitar sepuluh kali lebih banyak dari toko buku fisik terbesar. Komentarkomentar dan resensi-resensi yang menyajikan atraksi yang unik dari sebuah situs web. Surat-surat kabar seperti New York Times dan pembaca kemudian menambahkannya ke dalam sistem. Perusahaan bersaing sebagai perantara 
informasi (information broker) dan tidak hanya sebagai penjual eceran seperti yang dilakukan banyak toko-toko buku fisik. Mekanisme penyaringan kolaboratif memungkinkan perusahaan untuk mendatangkan saran-saran bagi buku-buku yang sesuai. Perusahaan mengumpulkan resensi-resensi dari pelanggan dan menambahkannya dengan isi editorial di dalam situs mereka. Ketika isi ini berkembang, maka isi akan menarik yang lain untuk menambahkan campuran yang lengkap sehingga menciptakan siklus yang baik. Esensinya hal ini secara eksplisit berusaha untuk menciptakan komunitas di sekitar kebutuhan-kebutuhan akan transaksi. Amazon secara konsisten memotong daftar harga sebanyak 40\%. Perusahaan memenuhi proposisi nilai inti misalnya kenyamanan, pilihan, dan layanan. Amazon.com adalah pionir yang menjalankan bisnis toko buku murni secara online dan saat ini telah memiliki pelanggan setia di seluruh dunia.

Penelitian terdahulu evaluasi aplikasi e-commerce pada sektor toko buku online dengan metode EWAM perbandingan di Swiss dan Australia tahun 2005 menghasilkan amazon.com sebagai Best Practice Profile (Leimstoll, Kurnia, dan Schubert, 2005a). Pada tesis ini peneliti mengambil amazon.com sebagai Standar De Facto, karena Pertama, amazon.com telah menjalankan bisnisnya murni secara online sejak pertama kali didirikan sampai saat ini; Kedua, amazon.com telah dikenal luas dan memiliki jutaan pelanggan setia di seluruh dunia; Ketiga, amazon.com menjadi Best Practice Profile pada penelitian sebelumnya menggunakan metode EWAM untuk mengevaluasi aplikasi e-commerce pada toko buku online di Swiss. Meskipun pada penelitian ini amazon.com juga akan dievaluasi, namun tidaklah relevan apabila amazon.com ikut dibandingkan dengan empat situs web lokal yang berada di Indonesia yang menjadi fokus pada penelitian ini. Terdapat beberapa alasan peneliti yaitu: 1) Perbedaan aturan hukum pada transaksi elektronik antara negara asal amazon.com yaitu Amerika Serikat dengan Indonesia; 2) Asesor yang berpartisipasi pada penelitian ini seluruhnya merupakan konsumen yang berada di Indonesia, sehingga hasil evaluasinya merupakan representasi dari perspektif konsumen di Indonesia; 3) Standar kriteria-kriteria pada setiap fase transaksi elektronik yang diimplementasikan pada aplikasi e-commerce amazon.com dengan berhasil belum tentu bisa dan harus 
diadopsi oleh situs-situs web dengan aplikasi e-commerce di Indonesia; 4) Belum diketahui apakah amazon.com juga menjual buku-buku berbahasa Indonesia dari penerbit di Indonesia; 5) Fokus penelitian ini sesuai dengan judul tesis adalah mengevaluasi aplikasi e-commerce pada toko buku online di Indonesia dengan metode EWAM. 


\section{BAB 5 \\ PENGUMPULAN DAN ANALISIS DATA}

Bab ini mendiskusikan kegiatan analisis data yang dikumpulkan dari instrumen kuesioner online (EWAM tool) terhadap 4 situs web lokal yang dinilai, satu situs web internasional sebagai Standar De Facto, dan kontribusi 20 asesor dalam penelitian ini.

\subsection{Persiapan dan Analisis Data}

Data dikumpulkan melalui Internet dengan kuesioner online (EWAM tool) yang mempertahankan struktur yang paling sering digunakan dari tool aslinya (Selz \& Schubert 1997; Schubert \& Selz 2000 dikutip di dalam Schubert dan Kurnia, 2005)

EWAM tool dalam tesis ini dibuat menggunakan aplikasi Google Apps, situs web dibuat dengan Google Sites, dan instrumen kuesioner online dibuat dengan aplikasi Google Docs. Setiap asesor mengakses EWAM tool dengan mengetikkan URL: http://webatool.andipensil.com selanjutnya memasukan username dan password.

Setiap asesor melakukan dua tahap evaluasi yaitu pertama, mengevaluasi situs web dengan mengisi formulir evaluasi situs web dan kedua, asesor melakukan evaluasi kriteria dengan mengisi formulir evaluasi kriteria. Evaluasi kriteria diperlukan untuk melihat seberapa pentingnya sebuah kriteria pada sebuah sektor.

Penilaian asesor berdasarkan kepada 26 kriteria (daftar 26 kriteria secara lengkap dapat dilihat pada Lampiran 2 dan 3) dan dikelompokkan dalam fase-fase transaksi dari pasar elektronika meliputi Fase Informasi (Information Phase), Fase Kesepakatan (Agreement Phase), Fase Penyelesaian (Settlement Phase), dan Fase Setelah-Penjualan (After-Sales Phase). Sebagai tambahan, beberapa kriteria membangun dua kelompok lain: Komponen Komunitas (Community Component) 
dan Bagian Akhir (Final Section). Kriteria adalah milik satu dari kategori-kategori "Ease of Use" (EOU01-08), "Usefulness" (USEF01-15) atau "Trust" (TRUST1-2).

Dalam analisis data, EWAM tool mendefinisikan tiga profil yang menggambarkan evaluasi yang mengandung arti dari setiap web yang akan diuji:

- Sector Profile: profil dari sektor yang relevan. Penjualan buku online adalah sektor yang dipilih pada riset ini.

- Company Profile: Profil dari situs web. Terdapat empat profil situs web yang diuji yaitu balaipustakaonline.com, gramediaonline.com, erlangga.co.id, dan kutukutubuku.com. Situs web amazon.com dijadikan Standar De Facto pada riset ini.

- Best Practice Profile: profil yang berkembang paling baik dalam sektor yang relevan. Profil yang dipilih adalah sesuai dengan hasil evaluasi.

\subsection{Laporan Penilaian Web Individu}

Berdasarkan kepada penilaian situs web, sebuah laporan penilaian web individu mengandung representasi grafis dan analisis berikut yang menghasilkan (Schubert dan Kurnia, 2004):

1. Ringkasan dari kriteria individual dan hasil-hasilnya di dalam kategorikategori "Information Phase", "Agreement Phase", "Settlement Phase", "After-Sales Phase", "Community Component", "Final Section", dan kalkulasi skor totalnya.

2. Perbandingan situs-situs web yang diuji dengan rata-rata sektor dan Best Practice Profile dalam analisis kuantitatif dan representasi grafis tanpa memperhatikan peringkat penting kriteria.

3. Perbandingan dalam bentuk grafik hasil-hasil dari enam kategori $(1,2)$ dengan peringkat pentingnya profil-profil perusahaan dan sektor.

4. Perbandingan seperti pada poin (2) diatas, namun dengan memperhatikan peringkat penting kriteria. 
Schubert \& Dettling (2001) mengidentifikasikan tiga kelompok target yang berbeda yang akan memperoleh keuntungan-keuntungan berikut ini dari laporan penilaian web individu:

- Internet vendor: perbandingan dari kualitas orientasi konsumen dari situs web dengan profil sektornya atau kompetitor langsung. Rekomendasi yang mungkin bagi perbaikan digambarkan pada hasilnya.

- Potential Internet Vendor: Meningkatkan kesadaran pentingnya mengetahui kriteria-kriteria sukses dari situs-situs web e-commerce.

- Internet buyers/users: Menguji kualitas yang berorientasi kepada pelanggan dari situs web melalui pelanggan membeli secara online.

Tabel 5.1 meringkas jumlah asesor yang menilai situs-situs web yang diuji dalam studi ini. Evaluasi kualitatif berikutnya oleh peneliti memperlihatkan kejelasan dan kebergunaan hasilnya.

Tabel 5.1 Situs-situs web yang dievaluasi dan jumlah asesor

\begin{tabular}{|l|c|}
\hline \multicolumn{1}{|c|}{ Situs web } & Jumlah Asesor \\
\hline www.amazon.com & 19 \\
\hline www.balaipustakaonline.com & 20 \\
\hline www.erlangga.co.id & 19 \\
\hline www.gramediaonline.com & 19 \\
\hline www.kutukutubuku.com & 20 \\
\hline
\end{tabular}

Sebelum proses evaluasi dimulai, asesor-asesor diinstruksikan secara menyeluruh di dalam EWAM tool. Melatih asesor-asesor adalah sebuah proses pembelajaran penting yang melibatkan mereka dengan layanan-layanan e-commerce berkualitas tinggi. Data kemudian diserahkan secara online oleh asesor dan dianalisis oleh peneliti. 


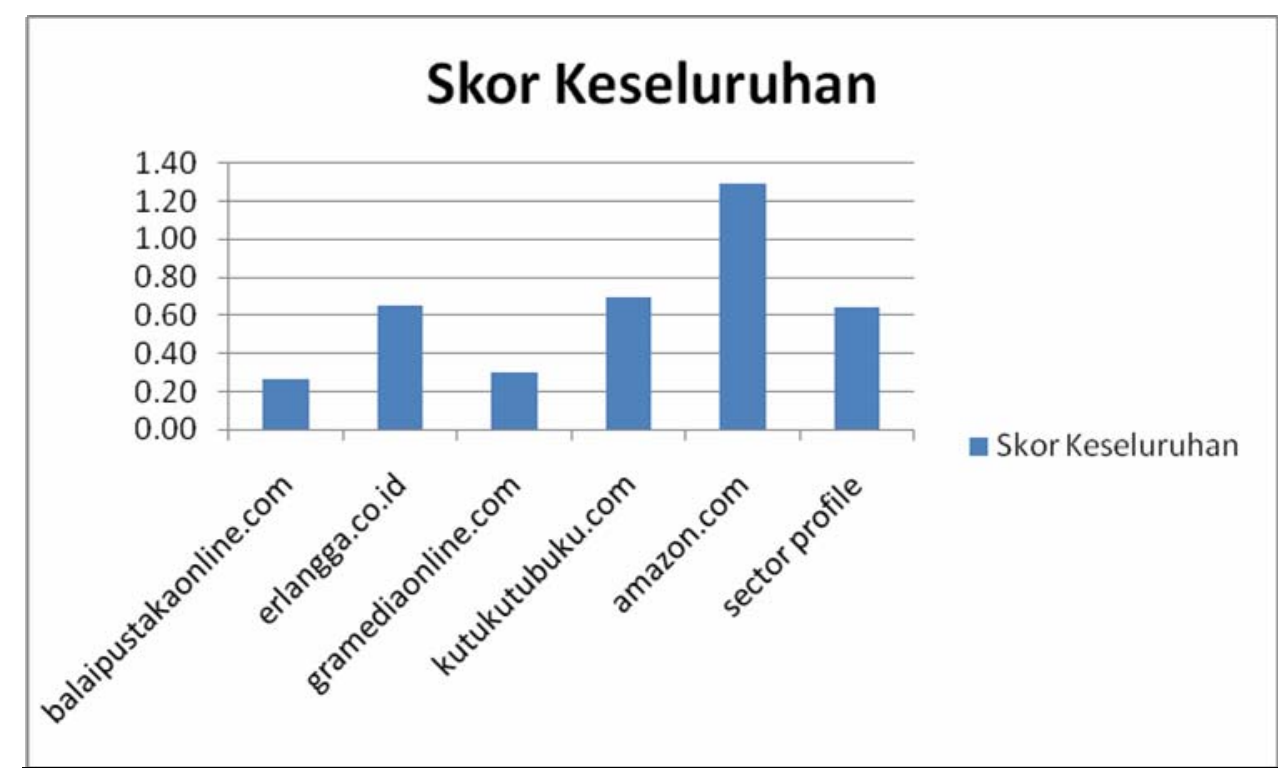

Gambar 5.1 Rangkuman Evaluasi Web Keseluruhan

Gambar 5.1 mengacu kepada Tabel 5.2 memperlihatkan rangkuman evaluasi web secara keseluruhan. Amazon.com (1.29) sebagai salah satu pelaku bisnis online murni muncul sebagai situs web dengan nilai tertinggi (Standar De Facto), diikuti oleh kutukutubuku.com (0.70) juga sebagai penjual buku online murni memperoleh nilai tertinggi dari situs-situs web lokal dan menjadi Best Practice Profile, erlangga.co.id (0.65) salah satu penerbit buku memperoleh nilai tertinggi kedua, disusul oleh toko buku gramediaonline.com (0.30) dan Penerbit balaipustakaonline.com (0.27) memperoleh nilai terendah.

Tabel 5.2 Rangkuman hasil evaluasi 4 situs web

\begin{tabular}{|c|l|c|c|c|c|c|c|}
\hline No. & \multicolumn{1}{|c|}{ Fase } & $\begin{array}{c}\text { Balaipustaka } \\
\text { online }\end{array}$ & erlangga & $\begin{array}{c}\text { Gramedia } \\
\text { online }\end{array}$ & $\begin{array}{c}\text { Kutukutubuku } \\
\text { (BPP) }\end{array}$ & $\begin{array}{c}\text { Amazon } \\
\text { (DFS) }\end{array}$ & SCP \\
\hline 1 & Information Phase & 0.43 & 0.88 & 0.41 & 0.83 & 1.41 & 0.79 \\
\hline 2 & Agreement Phase & 0.58 & 0.79 & 0.50 & 1.03 & 1.39 & 0.86 \\
\hline 3 & Settlement Phase & 0.00 & 0.40 & 0.07 & 0.52 & 1.40 & 0.47 \\
\hline 4 & After-Sales Phase & 0.18 & 0.53 & -0.05 & 0.43 & 0.97 & 0.41 \\
\hline & $\begin{array}{l}\text { Community } \\
\text { Component }\end{array}$ & -0.28 & 0.25 & -0.34 & 0.25 & 0.63 & 0.10 \\
\hline 6 & Final Section & 0.46 & 0.71 & 0.69 & 0.87 & 1.53 & 0.85 \\
\hline $\mathbf{7}$ & Overall Score & $\mathbf{0 . 2 7}$ & $\mathbf{0 . 6 5}$ & $\mathbf{0 . 3 0}$ & $\mathbf{0 . 7 0}$ & $\mathbf{1 . 2 9}$ & $\mathbf{0 . 6 4}$ \\
\hline
\end{tabular}

BPP: Best Practice Profile, DFS: De Facto Standard, SCP: Sector Profile 


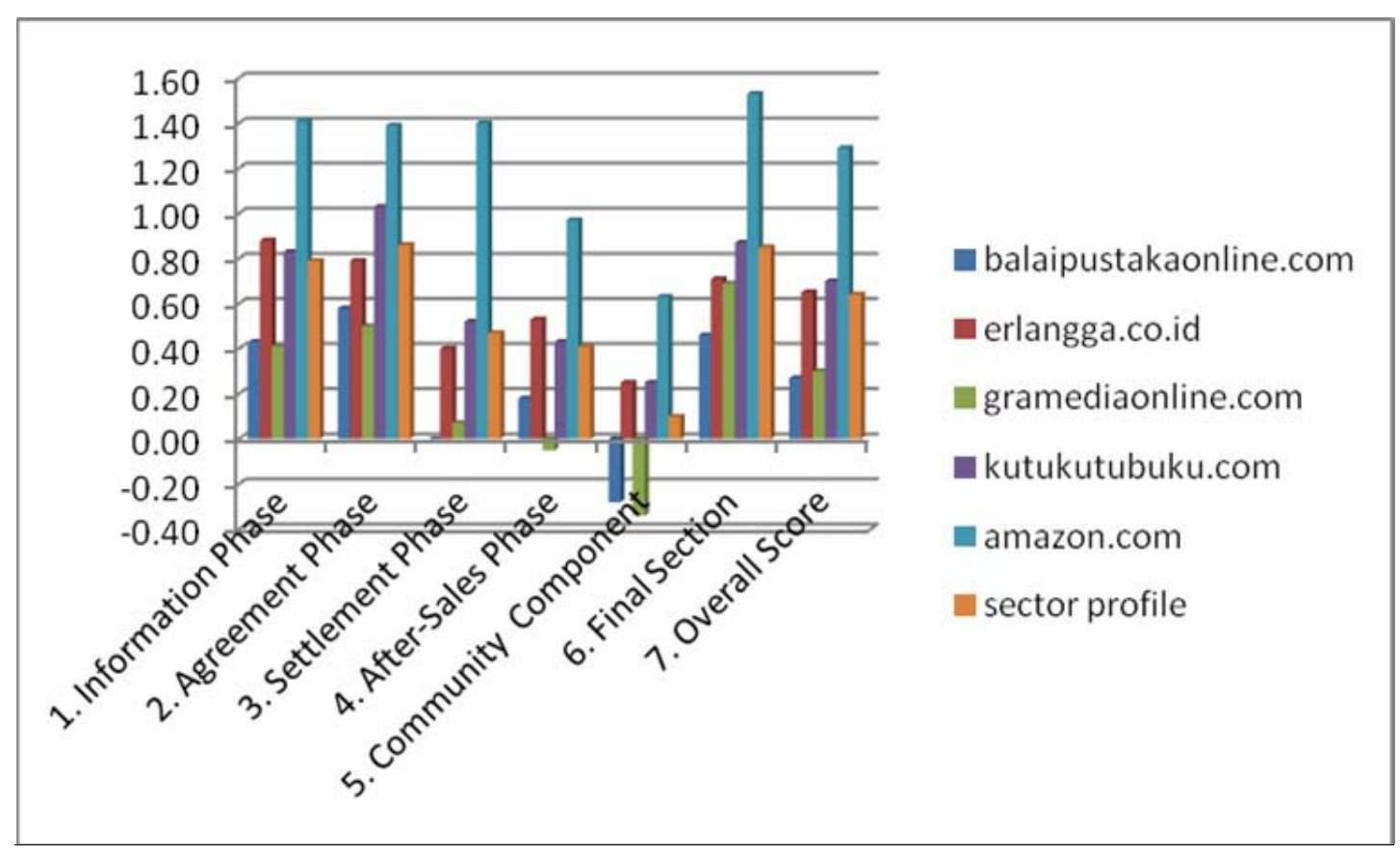

Gambar 5.2 Rangkuman Company Profile Penjualan Buku Online di Indonesia

Gambar 5.2 lebih jauh memperlihatkan hasil evaluasi web dalam setiap fase yang digunakan pada EWAM tool untuk seluruh situs web. Konsisten dengan Gambar 5.1, Gambar 5.2 mengindikasikan bahwa amazon.com (Standar De Facto) memperoleh nilai tertinggi di seluruh fase, kecuali Community Component (0.63). Sedangkan Information Phase (1.41), Agreement Phase (1.39), dan Settlement Phase (1.40) ketiga fase transaksi pada pasar elektronik telah dinilai memiliki kinerja yang baik oleh asesor (>1). After-Sales Phase (0.97) dan Final Section (1.53) tercermin pada kriteria-kriteria yang tercakup di dalamnya memiliki skor tertinggi. Kutukutubuku.com memiliki nilai tertinggi untuk situs web di Indonesia yang dievaluasi yaitu skor Agreement Phase (1.03) dan Final Section (0.87) adalah fase-fase yang mengalahkan kompetitor-kompetitor lainnya, hasil ini menjadikan kutukutubuku.com menjadi Best Practice Profile. Information Phase (0.88) skor tertinggi kedua dimiliki oleh erlangga.co.id mengalahkan kutukutubuku.com. Balaipustakaonline.com adalah merupakan situs web terburuk dalam evaluasi ini dengan skor keseluruhan (0.27), Settlement Phase (0.00) dan Community Component (-0.28) merupakan pencapaian yang buruk. Nilai fasefase yang rendah juga diperoleh oleh gramediaonline.com pada Settlement Phase (0.07), After-Sales Phase (-0.05), dan Community Component (-0.34) masing- 
masing menunjukkan kinerja yang buruk. Seperti diperlihatkan pada Gambar 5.2 bahwa penilaian umum, asesor tidak puas terhadap Community Component dari seluruh situs web yang dievaluasi, dan penilaian secara individual fase ini selalu menjadi yang terendah pada skornya. Maknanya adalah kecenderungan konsumen di Indonesia tidak tertarik bergabung ke dalam komunitas virtual. Kondisi ini bisa terjadi karena beberapa sebab antara lain: 1) buku bukan termasuk produk utama yang dibutuhkan oleh masyarakat di Indonesia (Asia Foundation, 2002), selain itu harga buku-buku juga masih relatif mahal, jadi tidak ada kebutuhan akan keterikatan di dalam komunitas virtual hanya untuk membeli sebuah buku, apalagi untuk menuliskan resensi terhadap buku tertentu secara gratis, menurut peneliti produk buku masih bersifat individual, pendapat komunitas untuk menurunkan harga buku juga belum tentu ditanggapi secara penuh oleh penerbit; 2) konsumen belum mempercayai apakah fokus utama ketersediaan isi dari komunitas merefleksikan kepentingan dari kelompok pembeli yang relevan atau bahkan hanya memberikan keuntungan bagi penjual saja; 3) pelanggan-pelanggan yang tergabung di dalam komunitas virtual belum mempercayai bahwa anggotaanggotanya memiliki kompetensi, apalagi jika jumlah anggotanya sedikit dan hanya anggota tertentu saja yang selalu mengirim informasi tanpa adanya umpan balik dari anggota lain; dan 4) Tidak terdapat akses ke komunitas virtual yang relevan, artinya pelanggan antusias untuk bergabung ke dalam komunitas virtual, namun akses tidak tersedia.

Tabel 5.3 Satu set data yang teragregasi balaipustakaonline.com

\begin{tabular}{|c|c|c|c|c|c|}
\hline \multirow{3}{*}{ 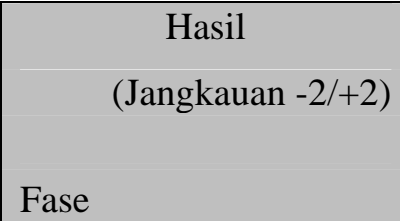 } & \multicolumn{3}{|c|}{ Company Profile } & \multirow{3}{*}{$\begin{array}{l}\text { Best Practice Profile } \\
\text { kutukutubuku.com } \\
\text { (BPP) }\end{array}$} & \multirow{3}{*}{$\begin{array}{l}\text { Sector Profile } \\
\text { (SCP) }\end{array}$} \\
\hline & & \multicolumn{2}{|c|}{ Selisih } & & \\
\hline & & ВРP & SCP & & \\
\hline Information Phase & 0.43 & -0.40 & -0.36 & 0.83 & 0.79 \\
\hline Agreement Phase & 0.58 & -0.45 & -0.28 & 1.03 & 0.86 \\
\hline Settlement Phase & 0.00 & -0.52 & -0.47 & 0.52 & 0.47 \\
\hline After-Sales Phase & 0.18 & -0.25 & -0.23 & 0.43 & 0.41 \\
\hline Community Component & -0.28 & -0.53 & -0.38 & 0.25 & 0.10 \\
\hline Final Section & 0.46 & -0.41 & -0.39 & 0.87 & 0.85 \\
\hline Overall Score & 0.27 & -0.43 & -0.37 & 0.70 & 0.64 \\
\hline
\end{tabular}


Tabel 5.3 sampai Tabel 5.6 dan Gambar 5.3 sampai Gambar 5.6 merupakan hasil analisis setiap fase yang memberikan perbandingan antara Company Profile, Best Practice Profile, dan Sector Profile tanpa memperhitungkan peringkat penting.

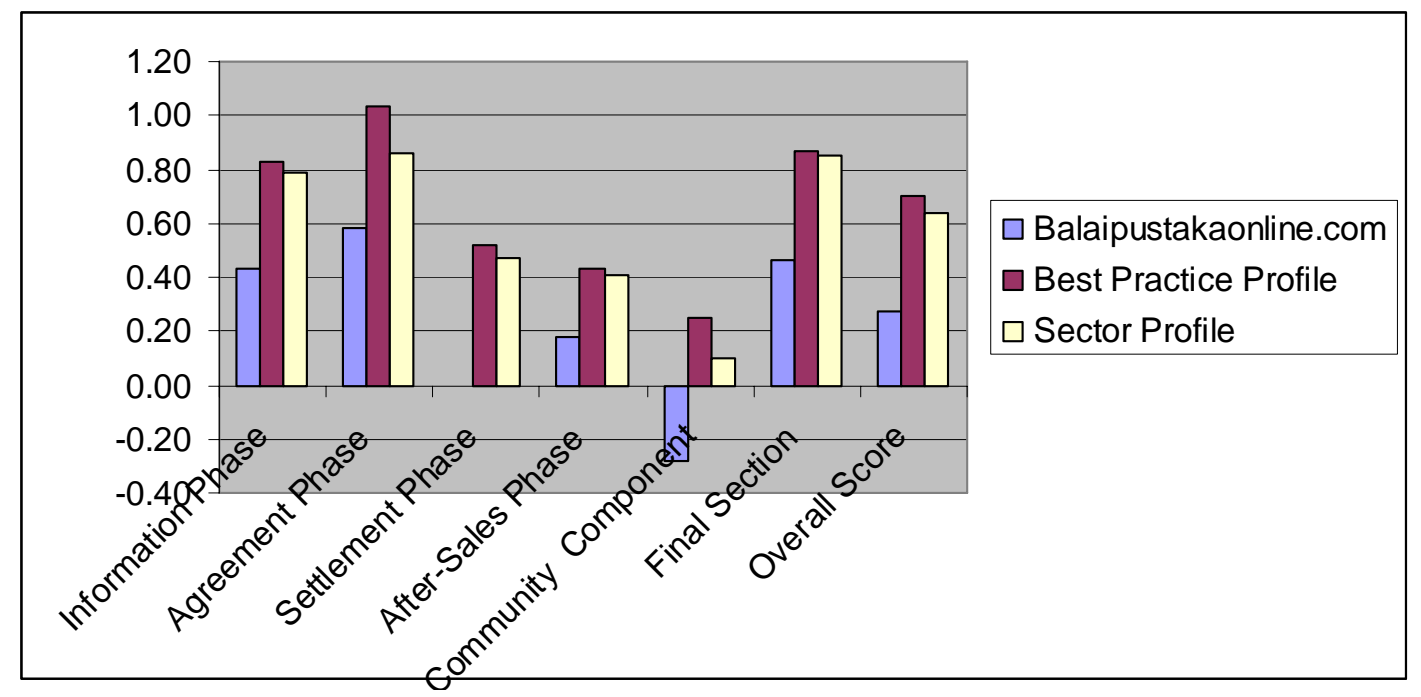

Gambar 5.3 Grafik Perbandingan balaipustakaonline.com, Best Practice profile, dan Sector Profile.

Situs web balaipustakaonline.com dinilai oleh 20 asesor. Gambar 5.3 di atas mengindikasikan bahwa balaipustakaonline.com mendapatkan nilai yang rendah di seluruh fase baik dibandingkan dengan Sector Profile apalagi dengan Best Practice Profile. Nilai keseluruhan dari situs web ini adalah (0.27).

Tabel 5.4 Satu set data yang teragregasi erlangga.co.id

\begin{tabular}{|c|c|c|c|c|c|}
\hline \multirow{3}{*}{$\begin{array}{c}\text { Hasil } \\
\text { (Jangkauan -2/+2) }\end{array}$} & \multicolumn{3}{|c|}{ Company Profile } & \multirow{3}{*}{$\begin{array}{l}\text { Best Practice Profile } \\
\text { kutukutubuku.com } \\
\text { (BPP) }\end{array}$} & \multirow{3}{*}{$\begin{array}{l}\text { Sector Profile } \\
\text { (SCP) }\end{array}$} \\
\hline & & \multicolumn{2}{|c|}{ Selisih } & & \\
\hline & & BPP & SCP & & \\
\hline Information Phase & 0.88 & 0.05 & 0.09 & 0.83 & 0.79 \\
\hline Agreement Phase & 0.79 & -0.24 & -0.07 & 1.03 & 0.86 \\
\hline Settlement Phase & 0.40 & -0.12 & -0.07 & 0.52 & 0.47 \\
\hline After-Sales Phase & 0.53 & 0.10 & 0.12 & 0.43 & 0.41 \\
\hline Community Component & 0.25 & 0.00 & 0.15 & 0.25 & 0.10 \\
\hline Final Section & 0.71 & -0.16 & -0.14 & 0.87 & 0.85 \\
\hline Overall Score & 0.65 & -0.05 & 0.01 & 0.70 & 0.64 \\
\hline
\end{tabular}




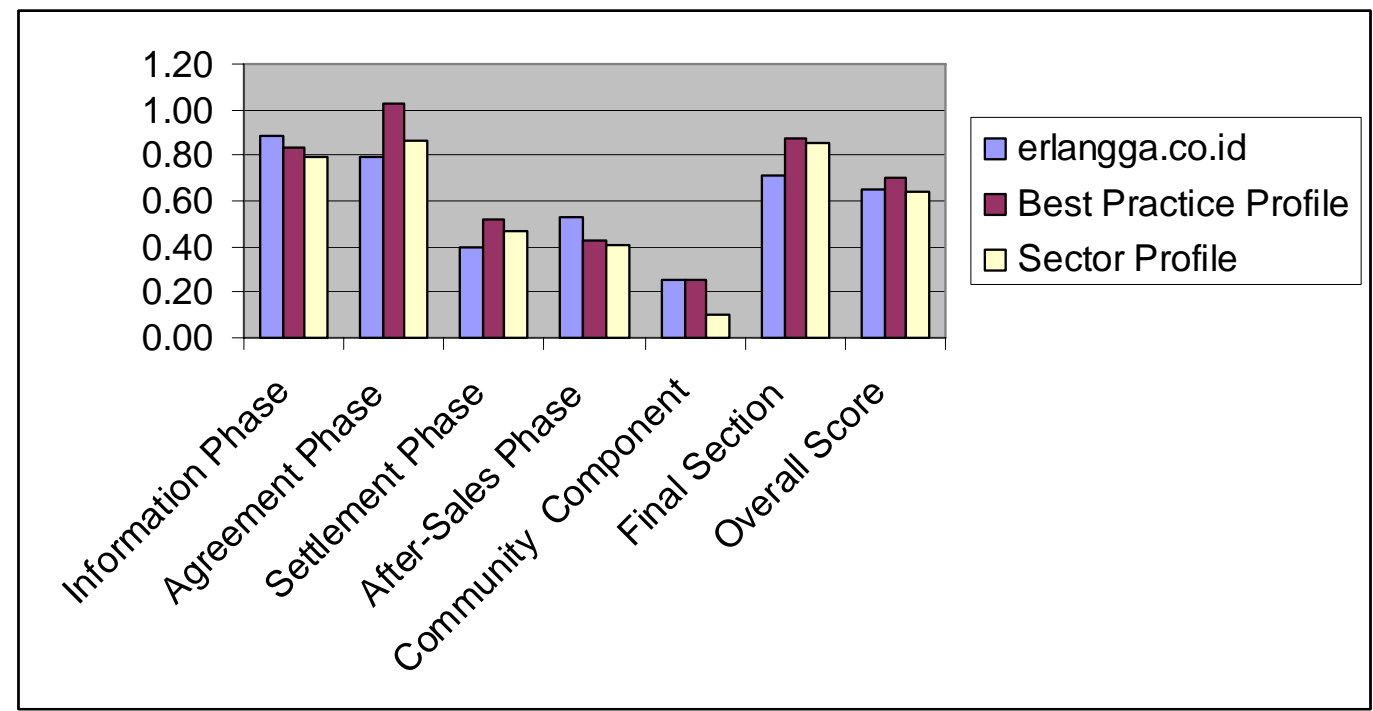

Gambar 5.4 Grafik perbandingan erlangga.co.id, Best Practice Profile, dan Sector Profile.

Berbeda dengan balaipustakaonline.com, erlangga.co.id memiliki kinerja yang lebih baik pada Information Phase (selisih SCP 0.09), After-Sales Phase (selisih SCP 0.12) dan Community Component (selisih SCP 0.15) dibandingkan dengan rata-rata sektor (SCP). Perhitungan secara keseluruhan situs web ini menempati urutan kedua setelah kutukutubuku.com (Best Practice Profile) dengan skor (0.65).

Tabel 5.5 Satu set data yang teragregasi gramediaonline.com

\begin{tabular}{|c|c|c|c|c|c|}
\hline \multirow{3}{*}{$\begin{array}{l}\text { Hasil } \\
\text { (Jangkauan -2/+2) }\end{array}$} & \multicolumn{3}{|c|}{ Company Profile } & \multirow{3}{*}{$\begin{array}{l}\text { Best Practice Profile } \\
\text { kutukutubuku.com } \\
\text { (BPP) }\end{array}$} & \multirow{3}{*}{$\begin{array}{c}\text { Sector Profile } \\
\text { (SCP) }\end{array}$} \\
\hline & & \multicolumn{2}{|c|}{ Selisih } & & \\
\hline & & BPP & SCP & & \\
\hline Information Phase & 0.41 & -0.42 & -0.38 & 0.83 & 0.79 \\
\hline Agreement Phase & 0.50 & -0.53 & -0.36 & 1.03 & 0.86 \\
\hline Settlement Phase & 0.07 & -0.45 & -0.40 & 0.52 & 0.47 \\
\hline After-Sales Phase & -0.05 & -0.48 & -0.46 & 0.43 & 0.41 \\
\hline Community Component & -0.34 & -0.59 & -0.44 & 0.25 & 0.10 \\
\hline Final Section & 0.69 & -0.18 & -0.16 & 0.87 & 0.85 \\
\hline Overall Score & 0.30 & -0.40 & -0.34 & 0.70 & 0.64 \\
\hline
\end{tabular}




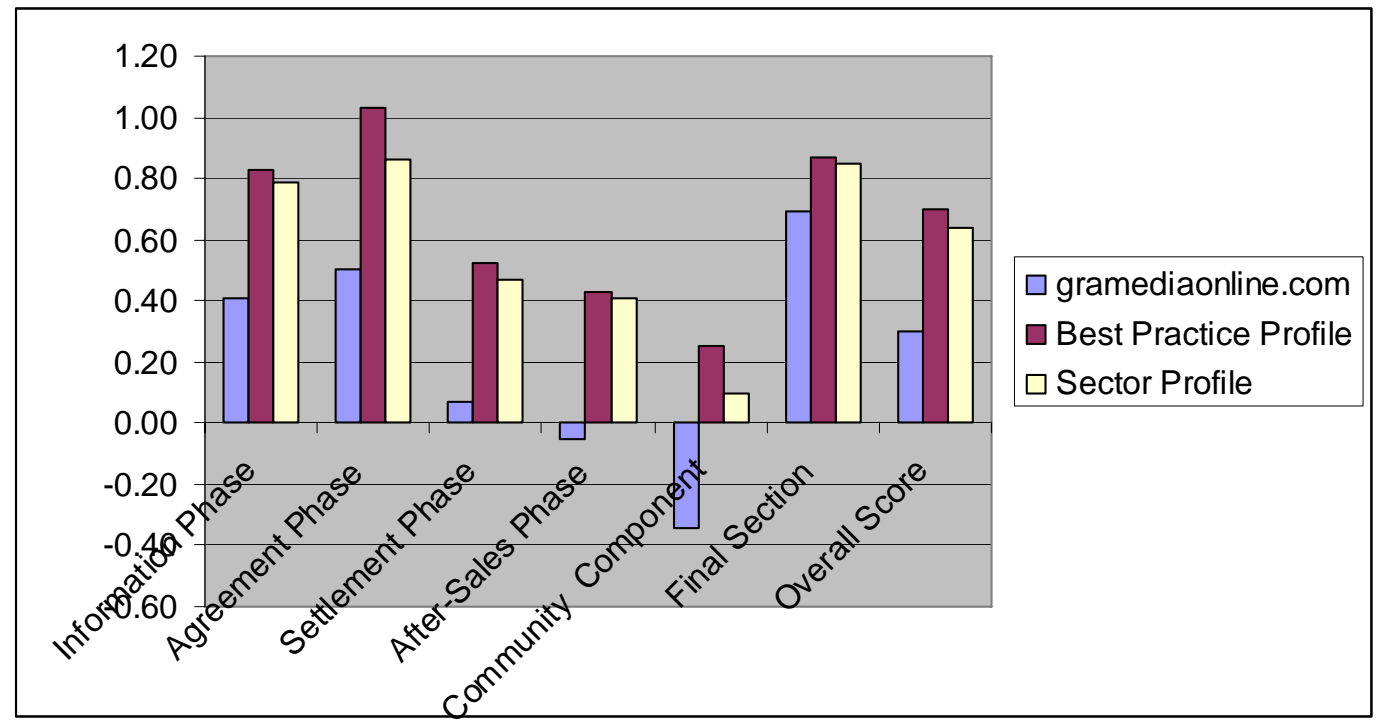

Gambar 5.5 Grafik Perbandingan gramediaonline.com, Best Practice Profile, dan Sector Profile.

PT. Gramedia terkenal sebagai toko buku fisik terlengkap di Indonesia, nilai skor total hanya terpaut selisih sebesar (0.03) selisih dari (0.30-0.27) dibandingkan dengan balaipustakaonline.com. Skor terendah terlihat pada Settlement Phase (0.07), After-Sales Phase (-0.05), dan Community Component (-0.34). Situs web ini terburuk kedua setelah balaipustakaonline.com.

Tabel 5.6 Satu set data yang teragregasi kutukutubuku.com

\begin{tabular}{|l|c|c|c|c|c|}
\hline \multicolumn{1}{|c|}{$\begin{array}{c}\text { Hasil } \\
\text { (Jangkauan -2/+2) }\end{array}$} & \multicolumn{2}{c|}{$\begin{array}{c}\text { Best Practice Profile } \\
\text { kutukutubuku.com }\end{array}$} & \multirow{2}{*}{$\begin{array}{c}\text { De Facto Standard } \\
\text { amazon.com }\end{array}$} & Sector Profile \\
Fase & & \multicolumn{2}{|c|}{ Selisih } & (DFS) & (SCP) \\
\cline { 3 - 4 } & DFS & SCP & & 0.79 \\
Information Phase & 0.83 & -0.58 & 0.04 & 1.41 & 0.86 \\
Agreement Phase & 1.03 & -0.36 & 0.17 & 1.39 & 0.47 \\
Settlement Phase & 0.52 & -0.88 & 0.05 & 1.40 & 0.41 \\
After-Sales Phase & 0.43 & -0.54 & 0.02 & 0.97 & 0.10 \\
Community Component & 0.25 & -0.38 & 0.15 & 0.63 & 0.85 \\
Final Section & 0.87 & -0.66 & 0.02 & 1.53 & 0.64 \\
Overall Score & 0.70 & -0.59 & 0.06 & 1.29 & \\
\hline
\end{tabular}




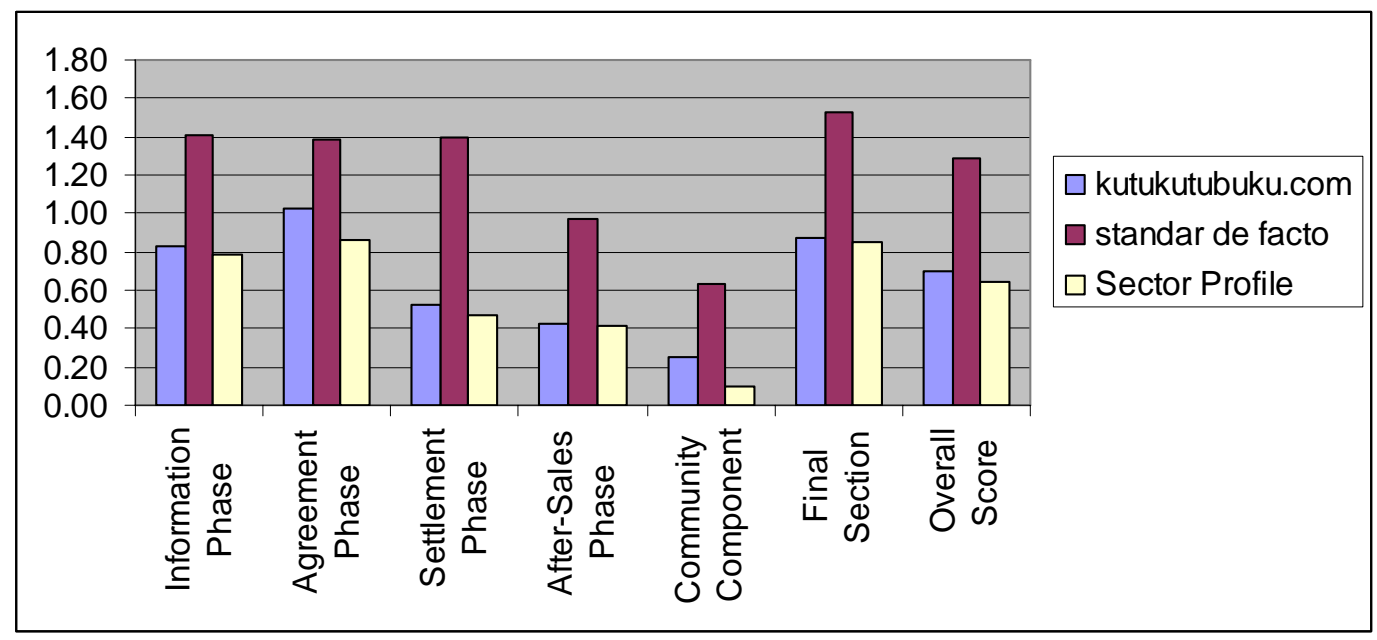

Gambar 5.6 Grafik Perbandingan kutukutubuku.com, Standar De Facto, dan Sector Profile.

Kutukutubuku.com adalah salah satu penjual buku yang murni menjalankan bisnisnya secara online yang dipilih pada studi ini. Skor seluruh fase situs web ini mengungguli rata-rata sektor, namun kalah secara keseluruhan dari amazon.com (Standar De Facto). Kutukutubuku.com memiliki skor tertinggi pada Agreement Phase (1.03) yang dinilai baik oleh asesor, nilai terendah terlihat pada fase Community Component (0.25) yang juga terjadi hasil yang sama pada seluruh situs web yang dievaluasi. Kutukutubuku.com menjadi situs web lokal terbaik (Best Practice Profile) berdasarkan hasil evaluasi tanpa memperhitungkan peringkat penting (importance).

Tabel 5.7 Peringkat Penting dari setiap kategori

\begin{tabular}{|l|c|}
\hline \multicolumn{1}{|c|}{ Fase } & $\begin{array}{c}\text { Peringkat Penting } \\
\text { (Jangkauan -2/+2) }\end{array}$ \\
\hline Information Phase & 1.47 \\
Agreement Phase & 1.45 \\
Settlement Phase & 1.35 \\
After-Sales Phase & 1.42 \\
Community Component & 0.74 \\
Final Section & 1.47 \\
\hline
\end{tabular}

Tabel 5.7 memperlihatkan ringkasan hasil evaluasi kriteria (hasil perhitungan lengkap lihat Lampiran 8 halaman 170) yang mana asesor menilai secara subyektif seberapa penting sebuah kriteria pada sektor penjualan buku online. 19 asesor berkontribusi dalam evaluasi kriteria melalui EWAM tool ini. 
Seluruh asesor menyatakan penting kriteria pada setiap fase (skala 1.00 menyatakan penting) berturut-turut Information Phase (1.47) dan Final Section (1.47), Agreement Phase (1.45), After-Sales Phase (1.42), Settlement Phase (1.35), dan pengecualian Community Component (0.74) dianggap tidak terlalu penting oleh asesor.

Peringkat penting memberikan petunjuk bahwa skor yang tinggi pada sebuah kriteria tertentu hasil evaluasi sebuah situs web, tidak akan bermanfaat jika ekspektasi konsumen rendah terhadap kriteria (hasil evaluasi kriteria) yang dinilai tersebut.

Gambar 5.7 didasarkan pada Tabel 5.8 memperlihatkan ringkasan skor penilaian situs web berdasarkan peringkat pentingnya. Amazon.com (1.32) memperoleh skor tertinggi (Standar De Facto), disusul oleh kutukutubuku.com (0.73) (Best Practice Profile) dan erlangga.co.id (0.67), kemudian gramediaonline.com (0.35) dan balaipustakaonline.com (0.31) mendapatkan peringkat terendah (Worst Practice Profile).

Tabel 5.8 Rangkuman evaluasi situs web dengan peringkat penting

\begin{tabular}{|l|c|c|c|c|c|c|c|}
\hline \multicolumn{1}{|c|}{ Fase } & $\begin{array}{c}\text { Peringkat } \\
\text { penting }\end{array}$ & $\begin{array}{c}\text { Balaipustaka } \\
\text { online }\end{array}$ & erlangga & $\begin{array}{c}\text { Gramedia } \\
\text { online }\end{array}$ & BPP & DFS & SCP \\
\hline $\begin{array}{l}\text { Information } \\
\text { Phase }\end{array}$ & 1.47 & 0.46 & 0.90 & 0.45 & 0.87 & 1.43 & 0.82 \\
\hline $\begin{array}{l}\text { Agreement } \\
\text { Phase }\end{array}$ & 1.45 & 0.58 & 0.79 & 0.51 & 1.03 & 1.41 & 0.86 \\
\hline $\begin{array}{l}\text { Settlement } \\
\text { Phase }\end{array}$ & 1.35 & 0.00 & 0.41 & 0.07 & 0.52 & 1.4 & 0.47 \\
\hline $\begin{array}{l}\text { After-Sales } \\
\text { Phase }\end{array}$ & 1.42 & 0.18 & 0.53 & -0.06 & 0.43 & 0.98 & 0.41 \\
\hline $\begin{array}{l}\text { Community } \\
\text { component }\end{array}$ & 0.74 & -0.27 & 0.25 & -0.35 & 0.25 & 0.63 & 0.10 \\
\hline Final Section & 1.47 & 0.48 & 0.71 & 0.72 & 0.88 & 1.53 & 0.86 \\
\hline $\begin{array}{l}\text { Overall } \\
\text { Score }\end{array}$ & $\mathbf{n . a .}$ & $\mathbf{0 . 3 1}$ & $\mathbf{0 . 6 7}$ & $\mathbf{0 . 3 5}$ & $\mathbf{0 . 7 3}$ & $\mathbf{1 . 3 2}$ & $\mathbf{0 . 6 7}$ \\
\hline
\end{tabular}

BPP: Best Practice Profile, DFS: De Facto Standard, SCP: Sector Profile 


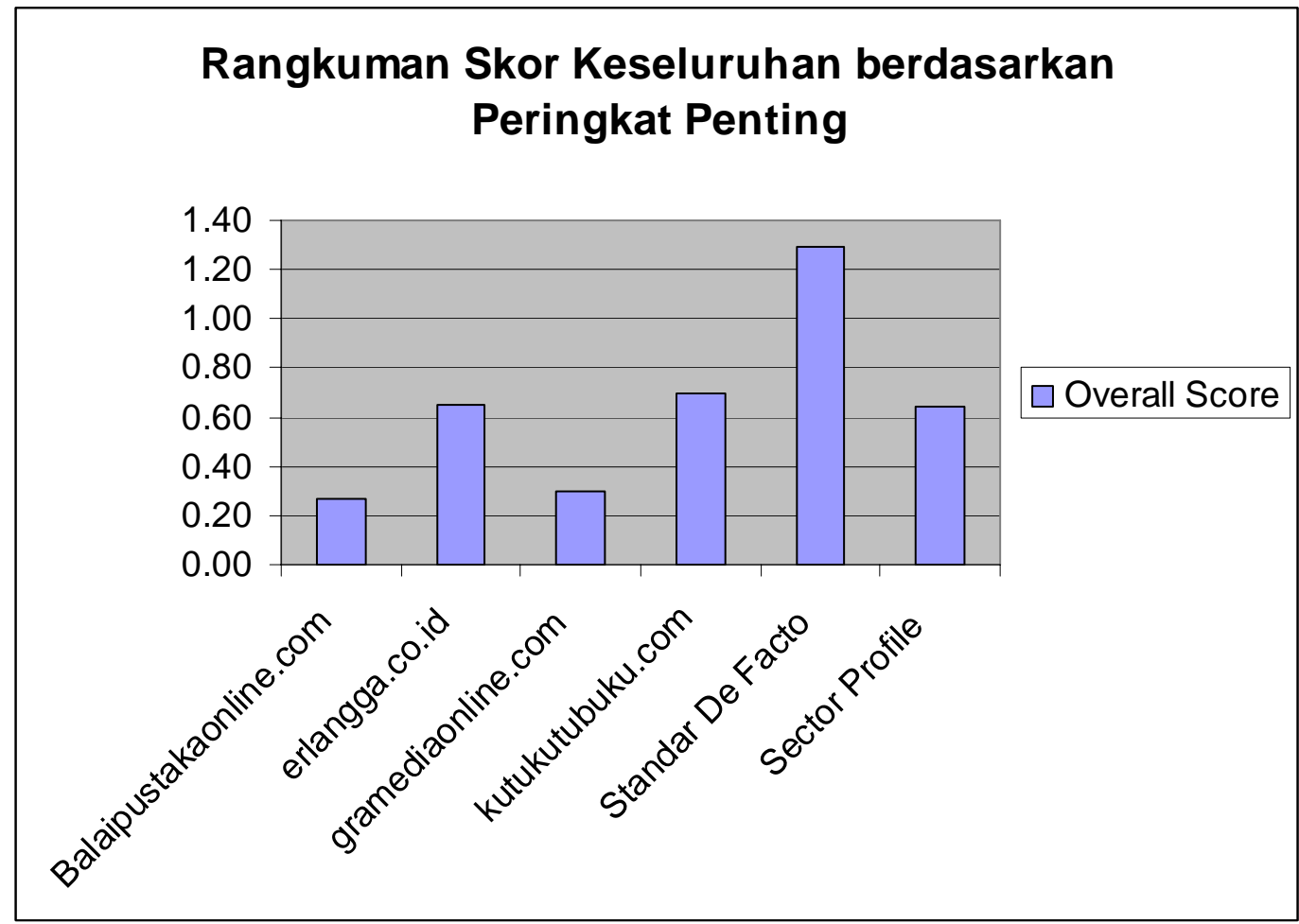

Gambar 5.7 Rangkuman penilaian situs web dengan peringkat pentingnya

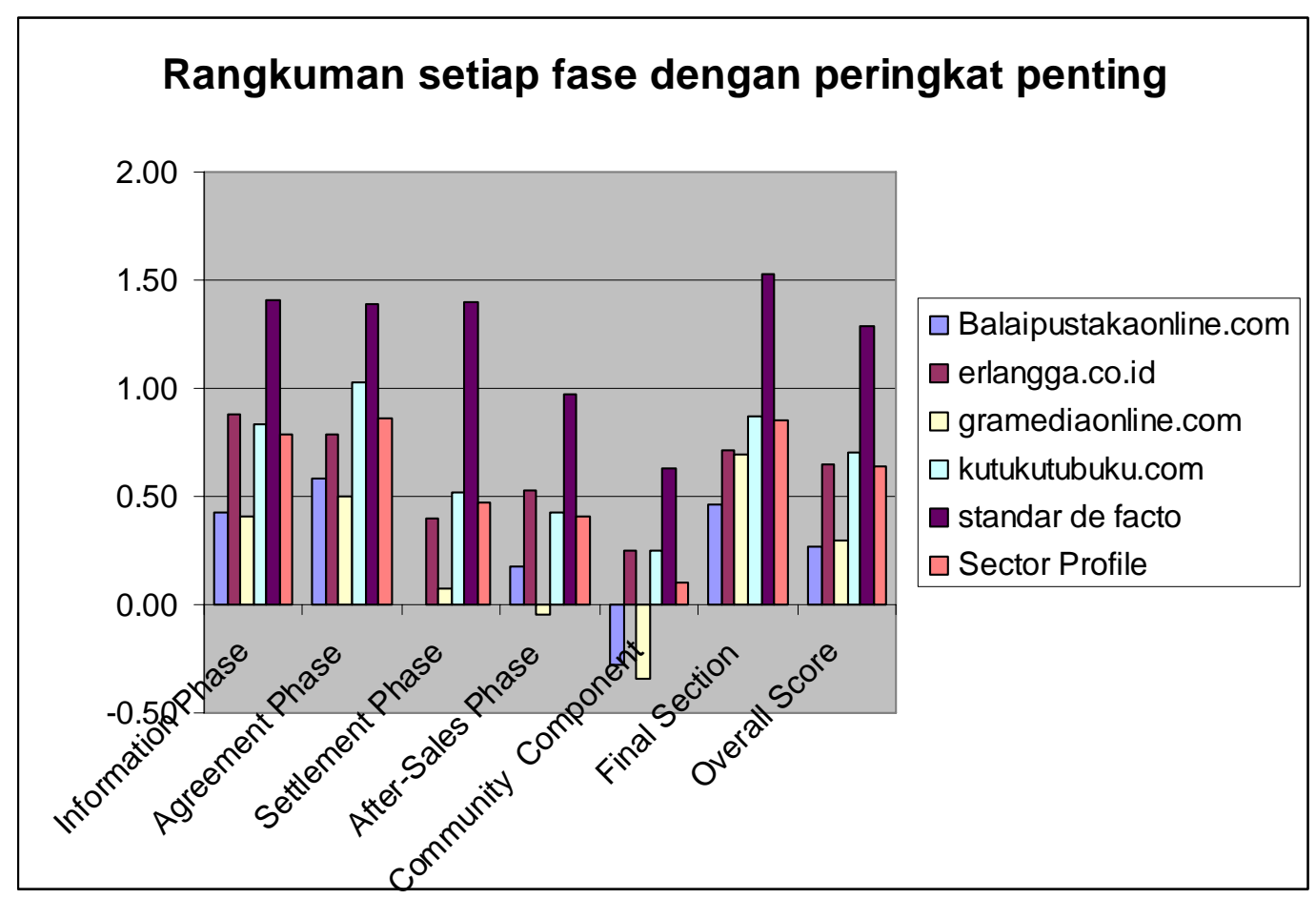

Gambar 5.8 Rangkuman penilaian Toko Buku Online per fase dengan

Peringkat Penting di Indonesia

Gambar 5.8 memperlihatkan lebih jauh rangkuman hasil evaluasi situs web dengan peringkat pentingnya pada setiap fase. Amazon.com sebagai situs web 
aplikasi e-commerce Standar De Facto memperoleh skor tertinggi di setiap fase. kutukutubuku.com memperoleh peringkat pertama sebagai situs web lokal yang diuji (Best Practice Profile) dan erlangga.co.id pada peringkat kedua, Balaipustakaonline.com peringkat ketiga, dan gramediaonline.com kembali mendapatkan nilai terendah berada di bawah rata-rata sektor.

Analisis kualitatif lebih jauh per fase akan diuraikan sebagai berikut:

- Pada Information Phase, kutukutubuku.com (Best Practice Profile) memperoleh penilaian yang baik untuk kriteria "Struktur Isi” (1.15) dan “Kuantitas Informasi” (1.20) artinya setiap asesor menilai penting kedua kriteria ini pada fase terkait. Pada kriteria "Kualitas Isi” kutukutubuku.com memperoleh nilai tertinggi (skor 1.20), kutukutubuku.com sangat perlu mempertahankan kriteria ini sebagai pelaku bisnis online murni. erlangga.co.id juga memperoleh skor yang tinggi pada tiga kriteria pertama "Kemudahan akses dari situs web dan produk-produknya” (skor 1.30), "Struktur Isi” (skor 1.21) dan "Kuantitas Informasi” (skor 1.21). Temuan juga menunjukkan bahwa kriteria "Sistem-sistem rekomendasi" tidak memuaskan bagi situs-situs web lokal.

- Pada Agreement Phase, menurut asesor kedua kriteria dalam fase ini penting (skor 1.45). Balaipustakaonline.com dan erlangga.co.id memperoleh nilai yang sama pada kriteria “Model-model dan metode-metode penetapan harga” (B: 0.55, E:0.55). gramediaonline.com dan balaipustakaonline.com menerima nilai rendah pada kedua kriteria "Desain dari prosedur pemesanan” (G: 0.57, B: 0.60) dan "Model-model dan metode-metode penetapan harga” (G: 0.30, B: 0.55), terlihat prosedur pemesanan cukup kompleks pada kedua situs web tersebut.

- Pada Settlement Phase, ketiga kriteria yang termasuk di dalam fase ini penting menurut asesor (skor 1.35). Perbandingan skor per kriteria berturut-turut untuk toko buku online balaipustakaonline.com, erlangga.co.id, kutukutubuku.com, dan gramediaonline.com adalah sebagai berikut: kriteria "Integrasi dari layanan-layanan umum” (B: 0.00, E: 0.27, K: 0.46, G: 0.18), “Integrasi dari aplikasi-aplikasi e-commerce” (B: -0.08, E: 0.27, K: 0.37, G: 0.17), “Perutean 
dan penelusuran” (B: -0.08, E: 0.08, K: 0.46, G: -0.18). Kriteria “Integrasi dari aplikasi-aplikasi e-commerce" menurut asesor tidak relevan untuk sektor penjualan buku online di Indonesia.

- Pada After-Sales Phase, menurut asesor kedua kriteria dalam fase ini penting (skor 1.42). Nilai terendah diperoleh gramediaonline.com untuk kriteria “Akses kepada dukungan pelanggan" (skor 0.04) dan "Kinerja dari dukungan pelanggan” (skor -0.14). Asesor menilai kedua kriteria ini tidak banyak diperhatikan oleh pelaku bisnis online, meskipun menurut asesor kriteria ini penting dalam mendukung transaksi online.

- Pada Community Component, terdapat empat kriteria yang berada dalam fase ini. Asesor menilai bahwa fase ini tidak terlalu penting untuk sektor penjualan buku online di Indonesia (skor 0.68). Perbandingan skor per kriteria berturutturut untuk toko buku online balaipustakaonline.com, erlangga.co.id, kutukutubuku.com, dan gramediaonline.com adalah sebagai berikut: kriteriakriteria “Akses ke sebuah komunitas virtual” (B: -0.21, E: 0.15, G: -0.40, K: 0.17), “Keuntungan dari relasi-relasi di dalam komunitas” (B: -0.07, E: -0.03, G: -0.22, K: 0.27 ), “Keuntungan dari ketersediaan isi di dalam komunitas” (B: -0.21, E: 0.40, G: -0.22, K: 0.14), dan "Pemberdayaan pelanggan yang dihasilkan dari komunitas” (B: -0.26, E: 0.17, G: -0.11, K: 0.10). Rendahnya nilai pada empat kriteria ini tidak terlalu mempengaruhi kinerja dari aplikasi $e$ commerce, karena ekspektasi konsumen pada fase ini juga rendah.

- Pada Final Section, terdapat tujuh kriteria yang tercakup yaitu "Ketersediaan sistem”, "Desain dari antarmuka pengguna”, "Meningkatkan produktivitas dengan menghemat waktu”, "Interaksi”, “Fungsi-fungsi personalisasi”, "Kepercayaan dari rekan bisnis (pemasok)", dan "Hal yang dapat dipercaya dari situs web dan situasi legal”. Seluruh asesor menilai penting fase ini. gramediaonline.com memperoleh nilai yang tinggi pada kriteria "Kepercayaan dari rekan bisnis (pemasok)” (skor 1.04), dan "Hal yang dapat dipercaya dari situs web dan situasi legal” (1.10). PT. Gramedia adalah salah satu penerbit dan penjual buku dan bekerja sama dengan banyak penerbit lain sehingga kedua kriteria tersebut harus terpenuhi, sedangkan kutukutubuku.com memperoleh skor yang mendekati baik pada kriteria "Hal yang dapat dipercaya 
dari situs web dan situasi legal” (0.95). kutukutubuku.com juga memperoleh nilai tertinggi diantara kompetitor-kompetitornya pada empat kriteria pertama, “Ketersediaan sistem” (skor 0.81), “Desain dari antarmuka pengguna” (skor 0.93), “Meningkatkan produktivitas dengan menghemat waktu” (skor 0.93), dan “Interaksi” (skor 0.81).

Hasil penilaian situs web amazon.com sebagai Standar De Facto adalah sebagai berikut:

- Pada Information Phase dengan skor peringkat penting (1.47), amazon.com memperoleh penilaian yang baik untuk kriteria "Struktur isi" (1.50) dan "Kuantitas informasi” (1.32) artinya setiap asesor menilai penting kedua kriteria ini pada fase terkait. Amazon.com menerima nilai tertinggi pada kriteria "Kemudahan akses dari situs web dan produkproduknya” (skor 1.59) dan situs ini mendapatkan nilai rendah pada kriteria "Menyampaikan manfaat-manfaat dari harga” (skor 0.96), meskipun demikian nilai ini mendekati skala (1.00) karena amazon.com konsisten berani memberikan harga 40\% lebih murah dari toko-toko fisik manapun.

- Pada Agreement phase dengan skor peringkat penting (1.45), amazon.com memperoleh skor tertinggi (skor 1.52) pada kriteria "Desain dari prosedur pemesanan”, sedangkan kriteria “Model-model dan metode-metode penetapan harga” (skor 0.90) mendekati nilai yang baik.

- Pada Settlement Phase dengan skor peringkat penting (1.35), amazon.com memperoleh penilaian yang baik menurut asesor pada kriteria-kriteria "Integrasi dari layanan-layanan umum” (skor 1.24), “Integrasi dari aplikasi-aplikasi e-commerce” (skor 1.14), dan "Perutean dan penelusuran” (skor 1.15).

- Pada After-Sales Phase dengan skor peringkat penting (1.42). amazon.com mendekati nilai yang baik pada kriteria-kriteria "Akses kepada dukungan pelanggan” (skor 0.81) dan “Kinerja dari dukungan pelanggan” (skor 0.86). 
- Pada Community Component dengan skor peringkat penting (0.74), amazon.com memperoleh hasil rendah untuk setiap kriteria dalam fase ini. Berikut ini penilaian kriteria-kriteria untuk amazon.com: “Akses ke sebuah komunitas virtual” (skor 0.44), “Keuntungan dari relasi-relasi dalam komunitas" (skor 0.54), “Keuntungan dari ketersediaan isi dalam komunitas” (skor 0.40), dan "Pemberdayaan pelanggan yang dihasilkan dari komunitas” (0.35).

- Pada Final Section dengan skor peringkat penting (1.47). Amazon.com mendapatkan nilai yang tinggi di setiap kriteria yaitu "Ketersediaan sistem” (skor 1.41), “Desain dari antarmuka pengguna” (skor 1.35), “Meningkatkan produktivitas dengan menghemat waktu” (skor 1.35), “Interaksi” (skor 1.35), “Fungsi-fungsi personalisasi” (skor 1.06), “Kepercayaan dari rekan bisnis (pemasok)” (skor 1.32), dan “Hal yang dapat dipercaya dari situs web dan situasi legal” (skor 1.45).

Jika dibandingkan dengan hasil penilaian situs web lokal terbaik (Best Practice Profile) kutukutubuku.com dengan keseluruhan skor (0.73) dan rata-rata sektor (Sector Profile) dengan keseluruhan skor (0.67), maka amazon.com (Standar De Facto) masih jauh mengungguli dengan total skor (1.32) di seluruh fase. Hasil ini menunjukkan bahwa perlu adanya perbaikan pada tampilan situs web lokal pada fase-fase dan lebih jauh lagi pada kriteria-kriteria yang dinilai penting oleh asesor, agar ekspektasi konsumen lokal pada sektor penjualan buku online di Indonesia bisa terpenuhi. Meskipun demikian pasti terdapat perbedaan perilaku konsumen di Indonesia dibandingkan dengan negara-negara lain. Amazon.com pertama kali membuka usaha toko buku online dengan mengambil segmen pasar di negaranya sendiri yaitu Amerika Serikat dengan fitur-fitur aplikasi e-commerce yang dimiliki dan dibuat sendiri oleh pendirinya Jeff Bezos. Keberhasilan usahanya kemudian dilanjutkan dengan memperluas segmen pasar di luar Amerika Serikat dengan membangun gudang-gudang berukuran besar untuk menyimpan produk-produk yang akan dijual, tujuan utamanya adalah untuk mempermudah konsumen dalam melakukan transaksi online dengan mendapatkan keuntungan dari penghematan waktu pengiriman barang dan biaya pengiriman barang. Dengan mengacu kepada 
pengalaman praktis (Standar De Facto) dari amazon.com, toko-toko buku online di Indonesia dapat mengadaptasi fitur-fitur aplikasi e-commerce yang diterapkan pada amazon.com yang berlaku umum sesuai dengan kriteria-kriteria yang ada pada metode EWAM, kemudian mengembangkan sendiri fitur-fitur aplikasi $e$ commerce yang unik dan hanya bisa diterapkan sesuai dengan ekspektasi dari konsumen di Indonesia.

Tabel 5.9 Satu set data yang teragregasi dengan peringkat penting: balaipustakaonline.com

\begin{tabular}{|l|c|c|c|c|c|c|}
\hline \multirow{2}{*}{ Hasil (Jangkauan -2/+2) } & \multicolumn{5}{|c|}{$\begin{array}{c}\text { Best Practice } \\
\text { Profile }\end{array}$} & $\begin{array}{c}\text { Sector } \\
\text { Profile }\end{array}$ \\
\cline { 1 - 2 } & Importance & & \multicolumn{2}{|c|}{ Selisih } & (BPP) & (SCP) \\
\hline Fase & & & BPP & SCP & & \\
\hline Information Phase & 1.47 & 0.46 & -0.41 & -0.36 & 0.87 & 0.82 \\
Agreement Phase & 1.45 & 0.58 & -0.45 & -0.28 & 1.03 & 0.86 \\
Settlement Phase & 1.35 & 0.00 & -0.52 & -0.47 & 0.52 & 0.47 \\
After-Sales Phase & 1.42 & 0.18 & -0.23 & -0.23 & 0.43 & 0.41 \\
Community component & 0.74 & -0.27 & -0.52 & -0.37 & 0.25 & 0.10 \\
Final Section & 1.47 & 0.48 & -0.40 & -0.38 & 0.88 & 0.86 \\
Overall Score & n.a. & 0.31 & -0.42 & -0.36 & 0.73 & 0.67 \\
\hline
\end{tabular}

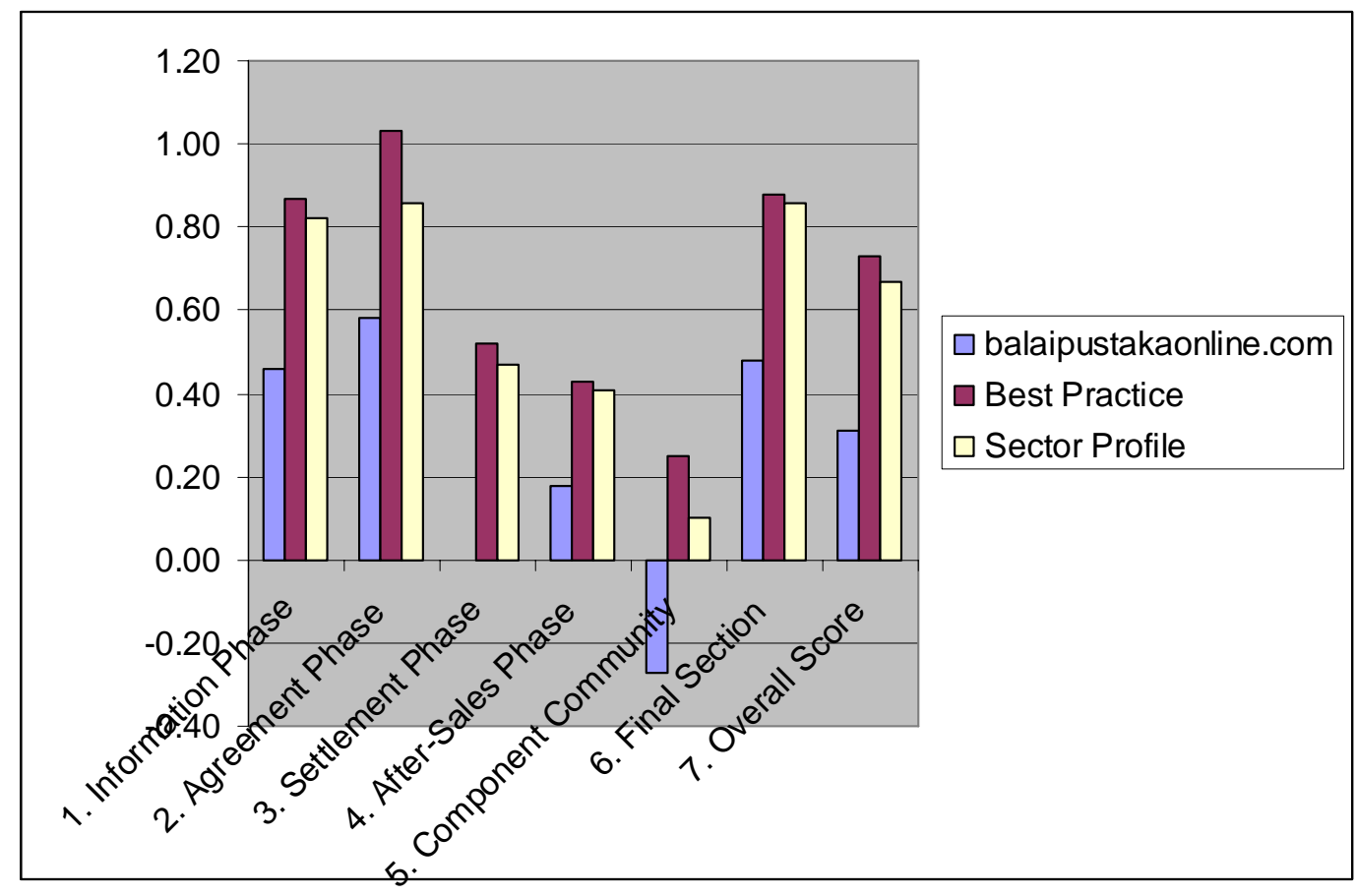

Gambar 5.9 Perbandingan balaipustakaonline.com, Best Practice dan Sector Profile dengan peringkat penting. 

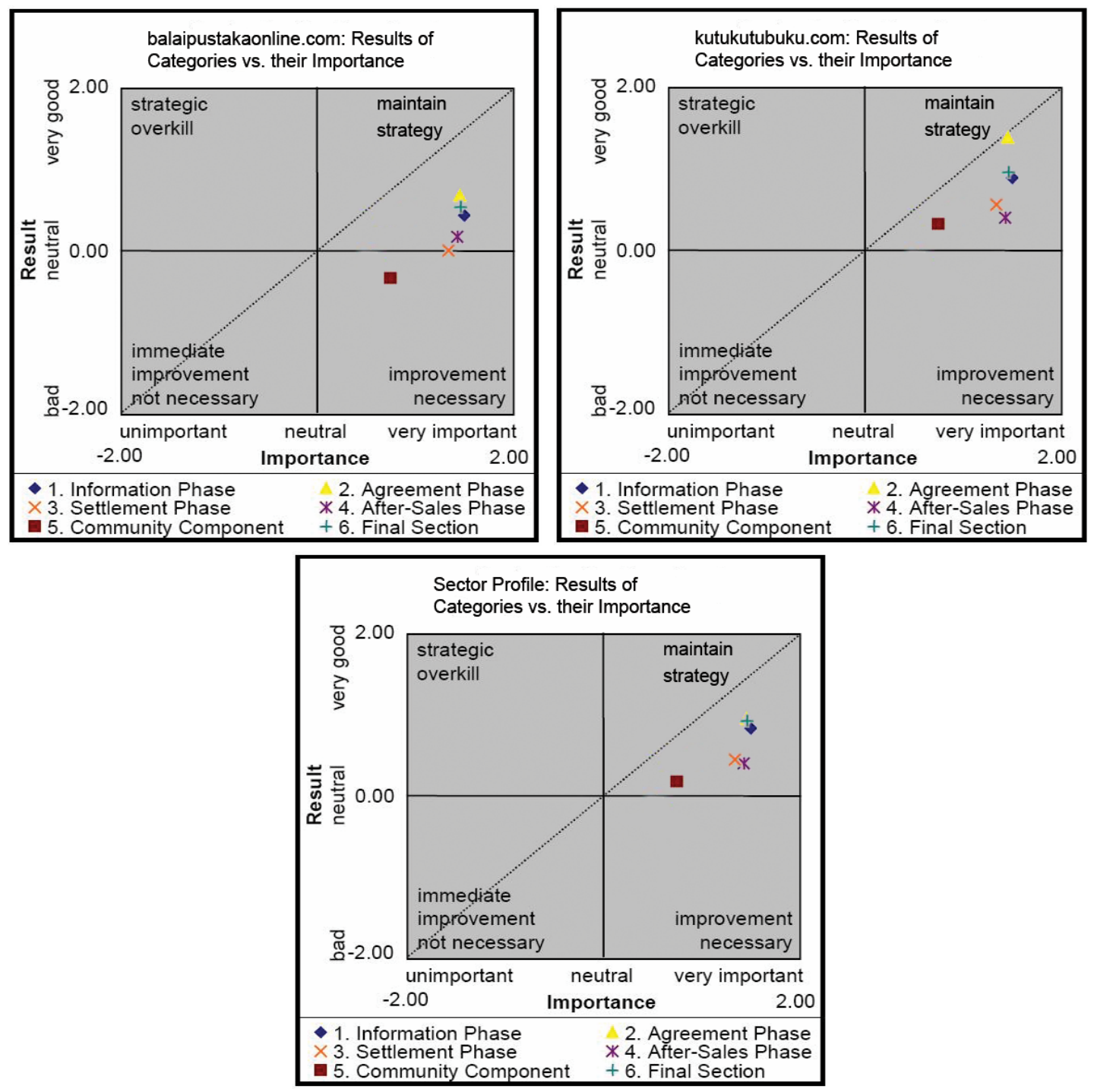

Gambar 5.10 Evaluasi strategi untuk balaipustakaonline.com, BPP, dan SCP

Gambar 5.10 memperlihatkan evaluasi strategi balaipustakaonline.com dibandingkan dengan kutukutubuku.com (Best Practice Profile) dan Sector Profile. Secara ideal setiap fase seharusnya berada pada posisi diagonal atau mendekati garis diagonal. Best Practice Profile secara keseluruhan setiap fasenya berada pada "maintain strategy", hanya satu fase yang mendekati diagonal yaitu Agreement Phase (1.03), sementara itu fase-fase lainnya menjauhi diagonal, meskipun demikian skor per fase dan skor keseluruhan lebih tinggi dibandingkan balaipustakaonline.com. Profil rata-rata sektor (Sector Profile) keseluruhan fasenya menjauhi diagonal, fase-fase yang penting menurut asesor yaitu Settlement Phase, After-Sales Phase dan Community component memperoleh skor 
jauh kurang dari separuhnya skala satu $(<1)$. Temuan ini mengindikasikan bahwa, rata-rata situs web lokal kriteria yang tercakup dalam fase-fase tersebut tidak memiliki kinerja yang baik. Akhirnya, berdasarkan grafik evaluasi strategi balaipustakaonline.com setiap fasenya sangat menjauhi diagonal, Community Component berada di wilayah strategi "improvement necessary", sedangkan Settlement Phase berada pada titik yang netral artinya posisi ini juga tidak mengindikasikan keadaan yang baik terpenuhinya kriteria sesuai ekspektasi konsumen. Jika dilihat lagi per kriteria "Integrasi dari layanan-layanan umum” (skor 0.00), "Integrasi dari aplikasi-aplikasi e-commerce" (skor -0.08), dan “Perutean dan penelusuran” (skor 0.08). Kriteria-kriteria ini harus diperbaiki segera, agar ekspektasi konsumen bisa tercapai. Secara umum penilaian situs web balaipustakaonline.com belum memenuhi ekspektasi dari konsumen.

Tabel 5.10 Satu set data yang teragregasi dengan peringkat penting: erlangga.co.id

\begin{tabular}{|c|c|c|c|c|c|c|}
\hline \multirow{3}{*}{$\begin{array}{l}\text { Hasil (Jangkauan -2/+2) } \\
\text { Fase }\end{array}$} & \multirow{3}{*}{ Importance } & \multicolumn{3}{|c|}{ Company Profile } & \multirow{3}{*}{$\begin{array}{l}\text { Best Practice } \\
\text { Profile } \\
\text { (BPP) }\end{array}$} & \multirow{3}{*}{$\begin{array}{l}\text { Sector } \\
\text { Profile } \\
\text { (SCP) }\end{array}$} \\
\hline & & & \multicolumn{2}{|c|}{ Selisih } & & \\
\hline & & & BPP & SCP & & \\
\hline Information Phase & 1.47 & 0.90 & 0.03 & 0.08 & 0.87 & 0.82 \\
\hline Agreement Phase & 1.45 & 0.79 & -0.24 & -0.07 & 1.03 & 0.86 \\
\hline Settlement Phase & 1.35 & 0.41 & -0.11 & -0.06 & 0.52 & 0.47 \\
\hline After-Sales Phase & 1.42 & 0.53 & 0.10 & 0.12 & 0.43 & 0.41 \\
\hline Community component & 0.74 & 0.25 & 0.00 & 0.15 & 0.25 & 0.10 \\
\hline Final Section & 1.47 & 0.71 & -0.17 & -0.15 & 0.88 & 0.86 \\
\hline Overall Score & n.a. & 0.67 & -0.06 & 0.00 & 0.73 & 0.67 \\
\hline
\end{tabular}

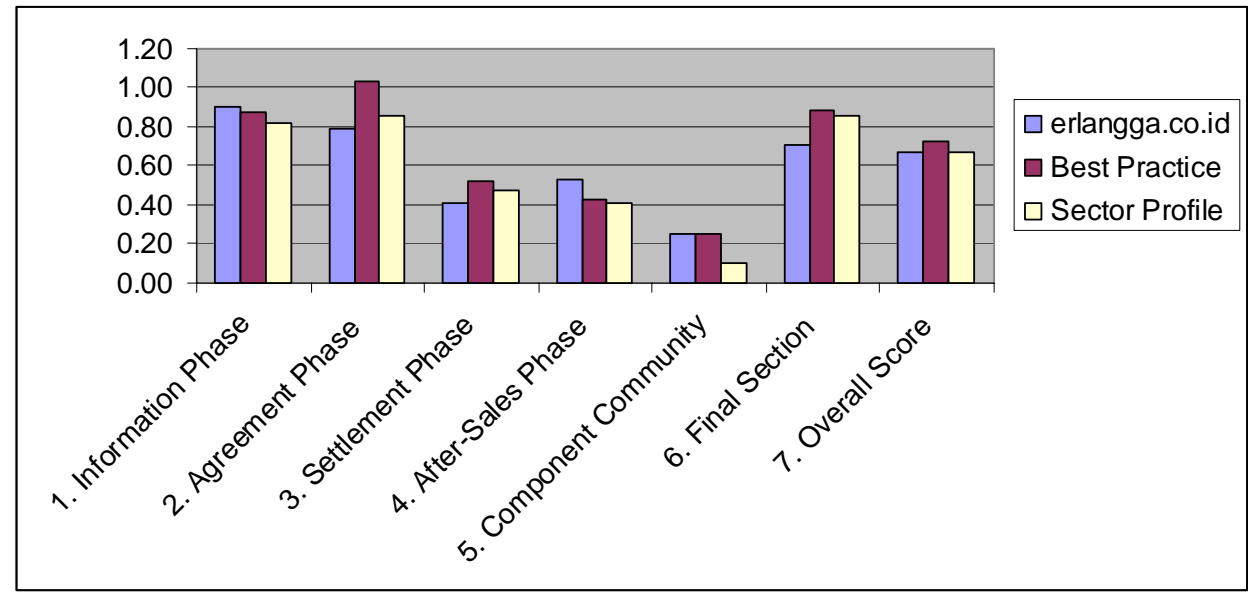

Gambar 5.11 Perbandingan erlangga.co.id, BPP dan SCP dengan peringkat penting 

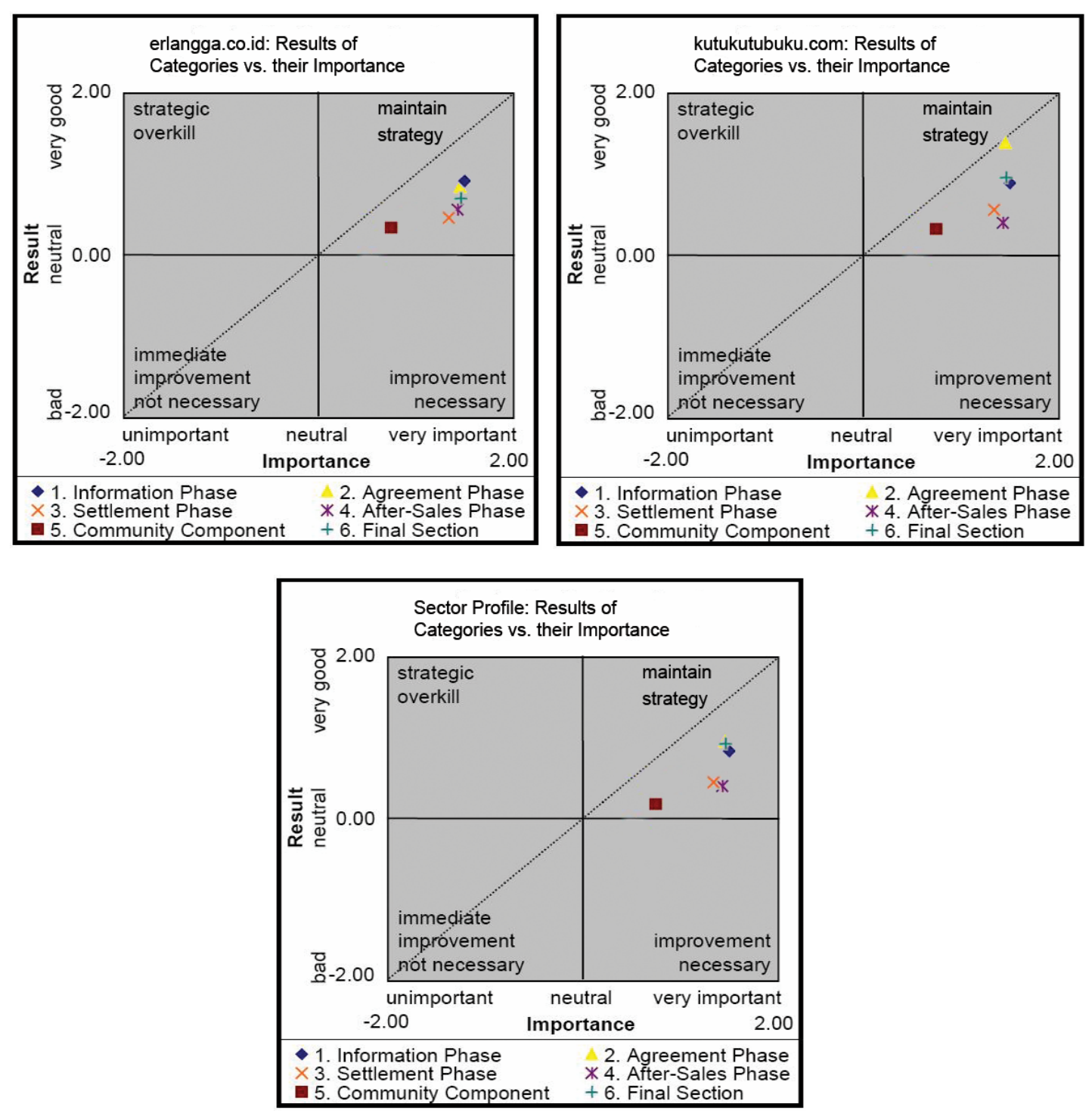

Gambar 5.12 Evaluasi strategi erlangga.co.id, BPP, dan SCP

Erlangga.co.id merupakan penerbit yang komitmen kepada visi dan misinya mengembangkan buku-buku pelajaran dan saat ini juga sudah memperluas tematema bukunya kepada bisnis dan pengembangan kepribadian. Evaluasi strategi menunjukkan bahwa secara keseluruhan setiap fase masih menjauhi diagonal. Meskipun berada pada wilayah "maintain strategy", Community Component kembali menunjukkan nilai yang rendah pada situs web lokal, memang asesor tidak menilai cukup penting fase ini bagi toko buku online di Indonesia, namun untuk perbaikan ke depan perlu juga dipertimbangkan. Settlement Phase dan After-Sales Phase juga mengindikasikan kondisi yang sama yaitu belum memenuhi ekspektasi dari konsumen. Jika dilihat lebih jauh skor kriteria pada 
Settlement Phase, “Integrasi dari layanan-layanan umum” (skor 0.27), “Integrasi dari aplikasi-aplikasi e-commerce” (skor 0.27), dan “Perutean dan penelusuran” (skor 0.49). Sedangkan After-Sales Phase, kriteria yang tercakup “Akses kepada dukungan pelanggan” (skor 0.63) dan “Kinerja dari dukungan pelanggan” (skor 0.27). Hanya tiga kriteria pertama pada Information Phase yang menunjukkan kinerja yang baik, "Kemudahan Akses dari Situs web dan Produk-produknya” (skor 1.30) "Struktur Isi” (skor 1.21), “Kuantitas Informasi” (skor 1.21), dan “Kualitas isi (skor 0.91). “Desain dari prosedur pemesanan” (skor 0.81) pada salah satu kriteria dalam Agreement Phase. Kriteria-kriteria yang tersebar dalam fase-fase yang belum disebutkan memperoleh nilai yang lebih rendah dari yang telah disebutkan. Sehingga bisa diindikasikan bahwa situs web secara keseluruhan belum memenuhi ekspektasi dari konsumen.

Tabel 5.11 Satu set data yang teragregasi dengan perangkat penting: www.gramediaonline.com

\begin{tabular}{|c|c|c|c|c|c|c|}
\hline \multirow{3}{*}{$\begin{array}{l}\text { Hasil(Jangkauan -2/+2) } \\
\text { Fase }\end{array}$} & \multicolumn{4}{|c|}{ Company Profile } & \multirow{3}{*}{$\begin{array}{l}\text { Best Practice } \\
\text { Profile } \\
\text { (BPP) }\end{array}$} & \multirow{3}{*}{$\begin{array}{l}\text { Sector } \\
\text { Profile } \\
\text { (SCP) }\end{array}$} \\
\hline & \multicolumn{2}{|l|}{ Importance } & \multicolumn{2}{|c|}{ Selisih } & & \\
\hline & & & BPP & SCP & & \\
\hline Information Phase & 1.47 & 0.45 & -0.42 & -0.37 & 0.87 & 0.82 \\
\hline Agreement Phase & 1.45 & 0.51 & -0.52 & -0.35 & 1.03 & 0.86 \\
\hline Settlement Phase & 1.35 & 0.07 & -0.45 & -0.40 & 0.52 & 0.47 \\
\hline After-Sales Phase & 1.42 & -0.06 & -0.49 & -0.47 & 0.43 & 0.41 \\
\hline Community component & 0.74 & -0.35 & -0.60 & -0.45 & 0.25 & 0.10 \\
\hline Final Section & 1.47 & 0.72 & -0.16 & -0.14 & 0.88 & 0.86 \\
\hline Overall Score & n.a. & 0.35 & -0.38 & -0.32 & 0.73 & 0.67 \\
\hline
\end{tabular}




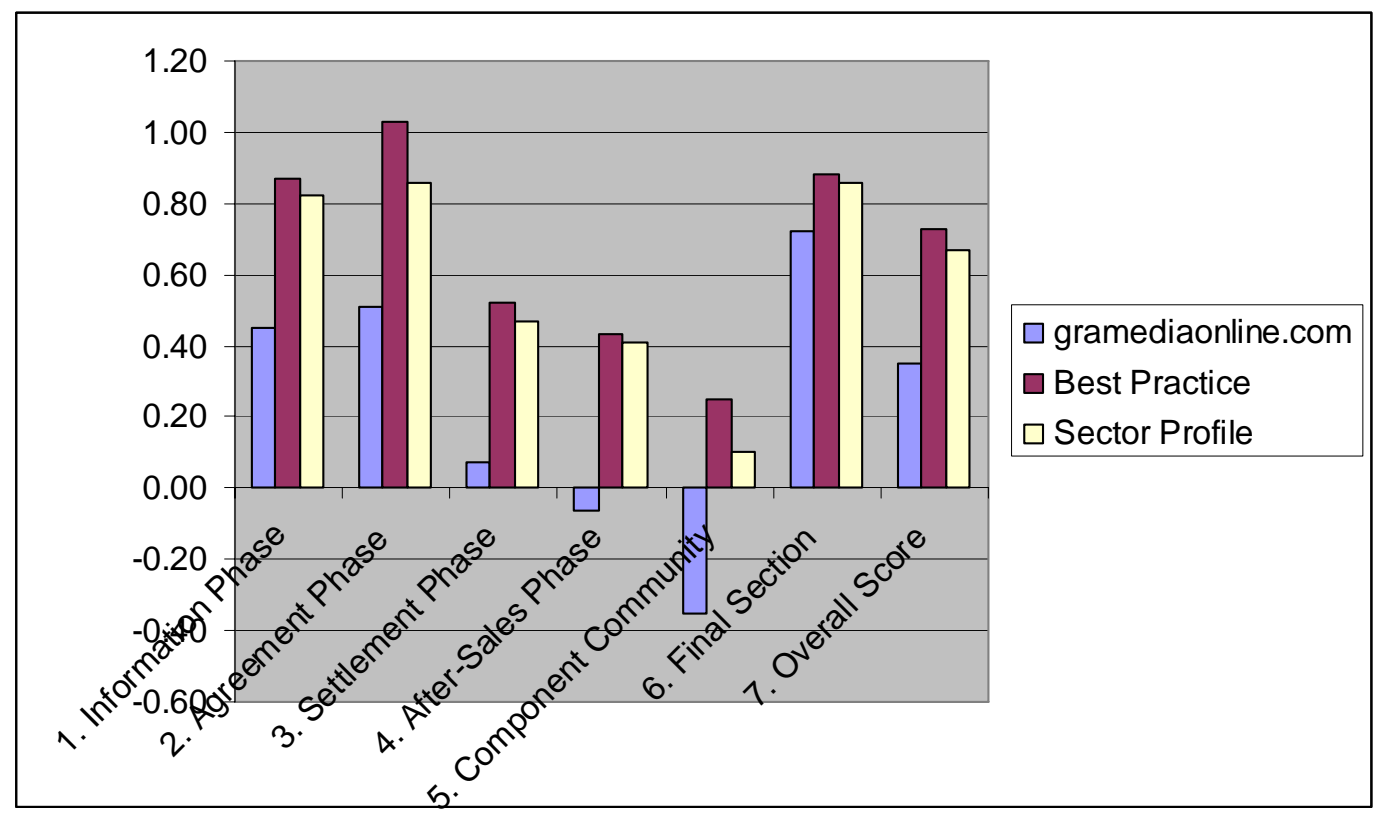

Gambar 5.13 Perbandingan gramediaonline.com, BPP dan SCP dengan peringkat penting
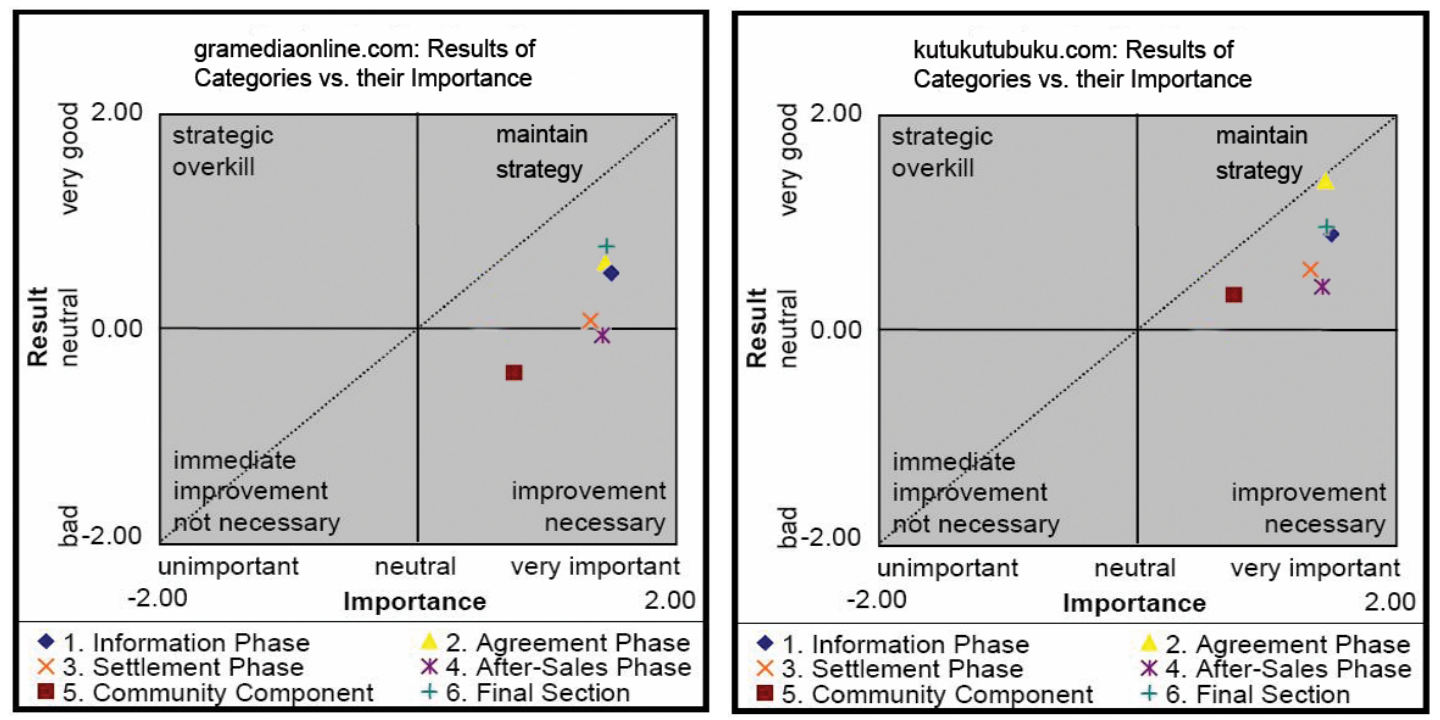


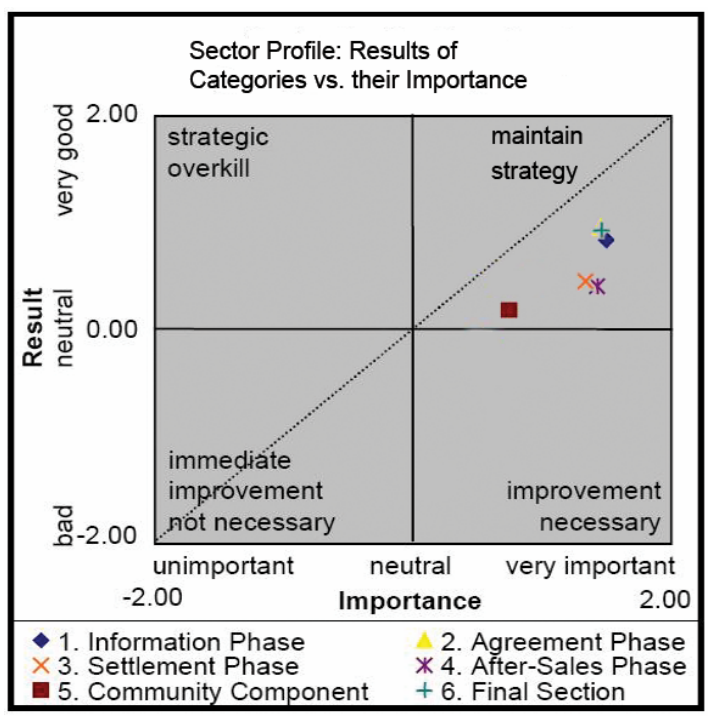

Gambar 5.14 Evaluasi strategi untuk gramediaonline.com, BPP, dan SCP

Berdasarkan grafik evaluasi strategi gramediaonline.com setiap fasenya sangat menjauhi diagonal, Community Component dan Settlement Phase berada di wilayah strategi "improvement necessary", Jika dilihat lagi per kriteria pada Settlement Phase "Integrasi dari layanan-layanan umum” (skor 0.18), “Integrasi dari aplikasi-aplikasi e-commerce" (skor 0.17), dan "Perutean dan penelusuran” (skor -0.18) nilai ini sangat jauh dari dapat dikatakan baik sesuai skala (skala 1 adalah baik). Kriteria yang menunjukkan nilai tertinggi adalah pada Information Phase "Kemudahan akses dari situs web dan produk-produknya” (skor 1.05), “Ketersedian sistem” (skor 0.75), “Kepercayaan dari rekan bisnis (pemasok)” (skor 1.04), dan "Hal yang dapat dipercaya dari situs web dan situasi legal” (skor 1.10) dari Final Section menduduki nilai yang cukup baik. Kriteria-kriteria ini (skala $>1$ ) harus dipertahankan dan ditingkatkan lagi, Sedangkan kriteria yang tidak disebutkan harus segera dioptimalkan agar sesuai dengan harapan konsumen. Saat ini secara umum penilaian situs web gramediaonline.com belum memenuhi ekspektasi dari konsumen (0.35). 
Tabel 5.12 Satu set data yang teragregasi kutukutubuku.com dengan peringkat penting

\begin{tabular}{|c|c|c|c|c|c|c|}
\hline \multirow{3}{*}{$\begin{array}{l}\text { Hasil (Jangkauan -2/+2) } \\
\text { Fase }\end{array}$} & & \multicolumn{3}{|c|}{ Company Profile } & \multirow{3}{*}{$\begin{array}{l}\text { De Facto } \\
\text { Standard } \\
\text { (DFS) }\end{array}$} & \multirow{3}{*}{$\begin{array}{l}\text { Sector } \\
\text { Profile } \\
\text { (SCP) }\end{array}$} \\
\hline & \multirow[t]{2}{*}{ Importance } & & \multicolumn{2}{|c|}{ Selisih } & & \\
\hline & & & BPP & SCP & & \\
\hline Information Phase & 1.47 & 0.87 & -0.56 & 0.05 & 1.43 & 0.82 \\
\hline Agreement Phase & 1.45 & 1.03 & -0.38 & 0.17 & 1.41 & 0.86 \\
\hline Settlement Phase & 1.35 & 0.52 & -0.88 & 0.05 & 1.40 & 0.47 \\
\hline After-Sales Phase & 1.42 & 0.43 & -0.55 & 0.02 & 0.98 & 0.41 \\
\hline Community component & 0.74 & 0.25 & -0.38 & 0.15 & 0.63 & 0.10 \\
\hline Final Section & 1.47 & 0.88 & -0.65 & 0.02 & 1.53 & 0.86 \\
\hline Overall Score & n.a. & 0.73 & -0.59 & 0.06 & 1.32 & 0.67 \\
\hline
\end{tabular}

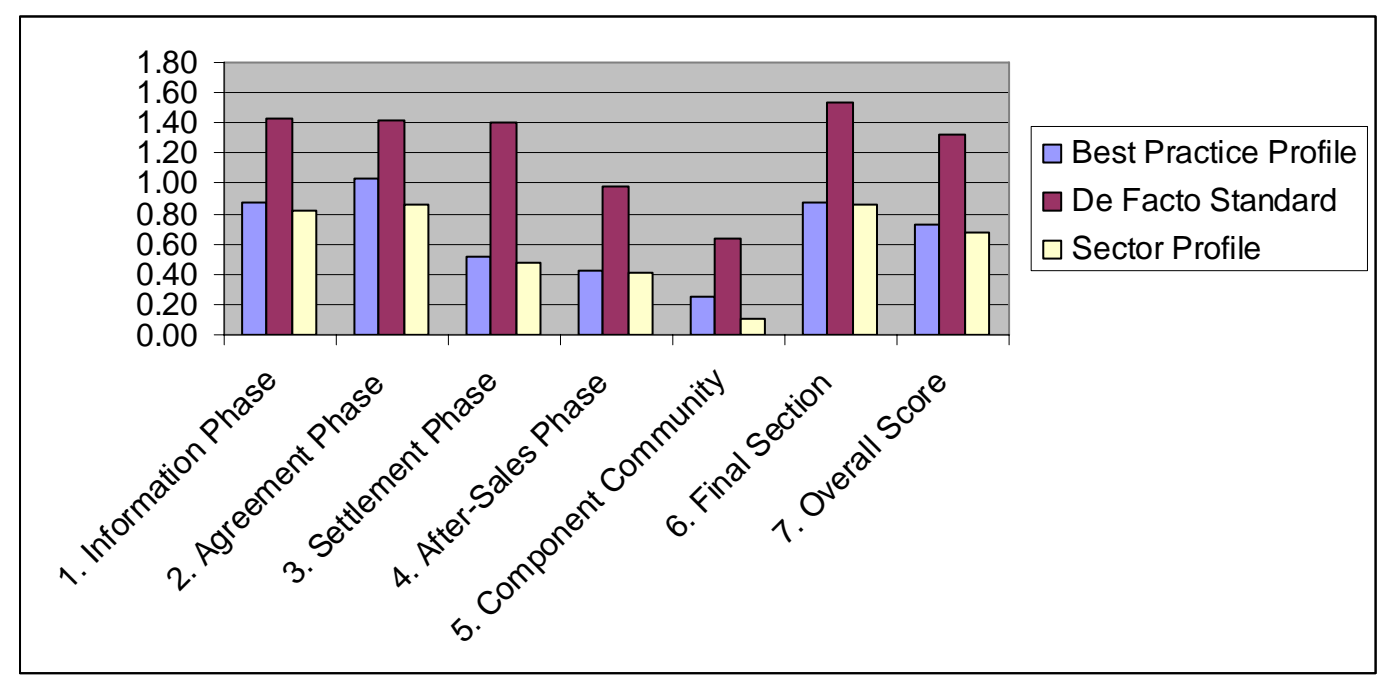

Gambar 5.15 Perbandingan kutukutubuku.com, DFS dan SCP dengan peringkat penting
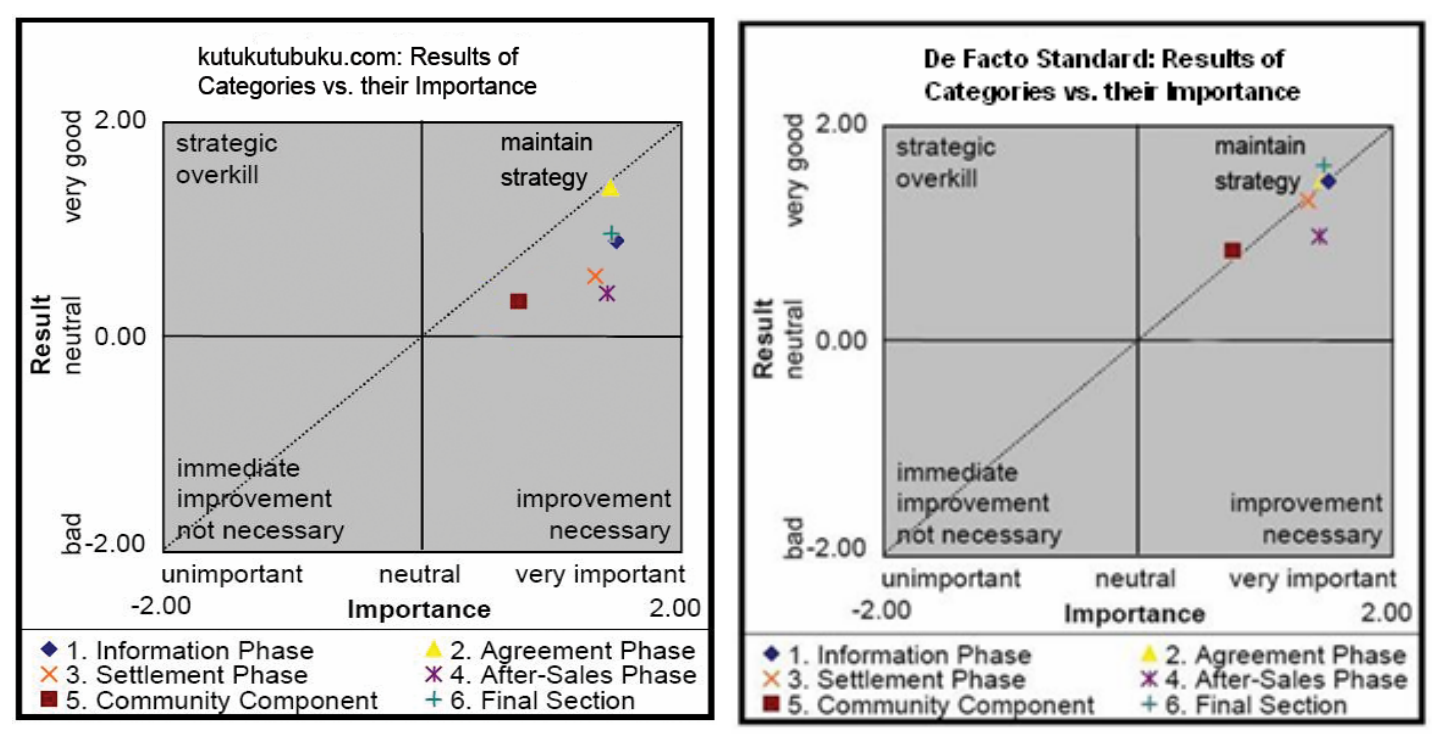


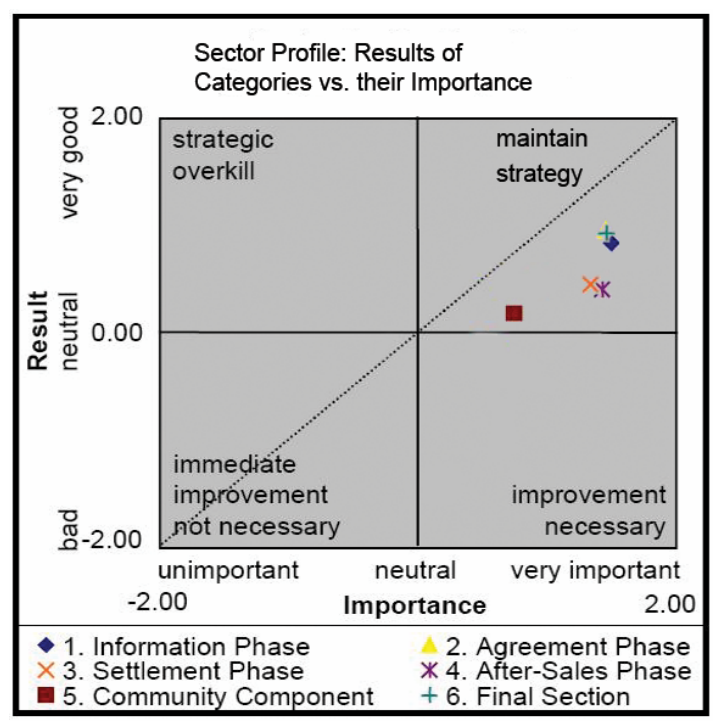

Gambar 5.16 Evaluasi strategi untuk kutukutubuku.com, DFS,dan SCP

Bagian terakhir dari evaluasi strategi adalah pada toko buku online kutukutubuku.com. Amazon.com (Standar De Facto) sebagian besar fase mendekati garis diagonal bahkan fase Final Section melampaui ke atas dari garis diagonal, hanya After-Sales Phase yang menjauhi garis diagonal, amazon.com berada pada wilayah strategi "maintain strategy" artinya perlu mempertahankan hasil yang baik dari terpenuhinya kriteria yang sesuai dengan ekspektasi konsumen. Sementara itu, jika dibandingkan dengan rata-rata sektor (Sector Profile) kutukutubuku.com mengungguli nilai pada seluruh fasenya. Agreement Phase memperoleh nilai tertinggi (skor 1.03), disusul dengan Final Section (0.88) dan Information Phase (0.87), namun demikian gambaran grafik menunjukkan penyebaran titik koordinat yang tidak fokus tapi menyebar dan cenderung menjauhi diagonal. Community Component, Settlement Phase, dan After-Sales Phase merupakan fase-fase yang cenderung menjauhi diagonal. Jika dilihat lebih jauh kriteria-kriteria “Akses ke sebuah komunitas virtual” (skor 0.17), “Keuntungan dari relasi-relasi di dalam komunitas” (skor 0.27), “Keuntungan dari ketersediaan isi di dalam komunitas” (skor 0.14), dan "Pemberdayaan pelanggan yang dihasilkan dari komunitas” (0.10) pada Community Component tidak menunjukkan performa yang baik. Kriteria-kriteria "Integrasi dari layananlayanan umum” (skor 0.46), "Integrasi dari aplikasi-aplikasi e-commerce” (skor 0.37), dan "Perutean dan penelusuran” (skor 0.46) pada Settlement Phase, dan 
kriteria-kriteria yang tercakup pada After Sales Phase, “Akses kepada dukungan pelanggan” (skor 0.46) dan “Kinerja dari dukungan pelanggan” (skor 0.26), kedua fase terakhir juga tidak mengindikasikan performa yang baik. Sehingga di setiap kriteria pada Settlement Phase dan After-Sales Phase perlu ditingkatkan pemenuhan kriteria agar sesuai dengan ekspektasi konsumen. Meskipun kutukutubuku.com (Best Practice Profile) dalam riset ini menempati urutan pertama dengan skor tertinggi, namun hasil analisis kualitatif berdasarkan kepada skor setiap kriteria, fase, dan keseluruhan belum bisa memenuhi ekspektasi dari konsumen.

\subsection{Analisis Statistik Deskriptif}

Analisis Statistik Deskriptif evaluasi situs web e-commerce pada sektor penjualan buku online dengan 20 asesor untuk 4 situs web lokal dan 1 situs web Standar De Facto diperlihatkan pada Tabel 5.13 di bawah ini:

Tabel 5.13 Analisis Statistik Deskriptif dari hasil kuesioner dengan EWAM tool

\begin{tabular}{|c|c|c|c|c|c|c|c|c|c|}
\hline \multicolumn{10}{|c|}{ Statistics } \\
\hline & \multicolumn{2}{|c|}{$\mathrm{N}$} & \multirow[b]{2}{*}{ Mean } & \multirow[b]{2}{*}{ Median } & \multirow[b]{2}{*}{ Mode } & \multirow{2}{*}{$\begin{array}{c}\text { Std. } \\
\text { Deviation }\end{array}$} & \multirow[b]{2}{*}{ Range } & \multirow[b]{2}{*}{ Minimum } & \multirow[b]{2}{*}{ Maximum } \\
\hline & Valid & Missing & & & & & & & \\
\hline Situs Web & 100 & 0 & 3.00 & 3.00 & $1^{a}$ & 1.421 & 4 & 1 & 5 \\
\hline $\begin{array}{l}\text { Kemudahan akses } \\
\text { dari situs web dan } \\
\text { produk-produknya } \\
\text { (EOU01) }\end{array}$ & 97 & 3 & 1.15 & 1.00 & 1 & .972 & 4 & -2 & 2 \\
\hline Struktur isi (EOU02) & 97 & 3 & 1.15 & 1.00 & 1 & .795 & 3 & -1 & 2 \\
\hline $\begin{array}{l}\text { Kuantitas informasi } \\
\text { (EOU03) }\end{array}$ & 97 & 3 & 1.09 & 1.00 & 1 & .879 & 4 & -2 & 2 \\
\hline $\begin{array}{l}\text { Kualitas isi } \\
\text { (USEF01) }\end{array}$ & 97 & 3 & .99 & 1.00 & 1 & .995 & 4 & -2 & 2 \\
\hline $\begin{array}{l}\text { Menyampaikan } \\
\text { manfaat-manfaat } \\
\text { dari harga (USEF02) }\end{array}$ & 97 & 3 & .70 & 1.00 & 1 & 1.192 & 4 & -2 & 2 \\
\hline $\begin{array}{l}\text { Membundel produk- } \\
\text { produk dan layanan- } \\
\text { layanannya } \\
\text { (USEF03) }\end{array}$ & 97 & 3 & .52 & 1.00 & 1 & 1.243 & 4 & -2 & 2 \\
\hline $\begin{array}{l}\text { Sistem-sistem } \\
\text { rekomendasi } \\
\text { (USEF04) }\end{array}$ & 97 & 3 & .27 & 1.00 & 1 & 1.295 & 4 & -2 & 2 \\
\hline $\begin{array}{l}\text { Menggunakan } \\
\text { hypermedia } \\
\text { (USEF05) }\end{array}$ & 97 & 3 & .42 & 1.00 & 1 & 1.306 & 4 & -2 & 2 \\
\hline $\begin{array}{l}\text { Desain dari } \\
\text { prosedur } \\
\text { pemesanan } \\
\text { (EOU04) }\end{array}$ & 97 & 3 & .99 & 1.00 & 1 & .896 & 3 & -1 & 2 \\
\hline
\end{tabular}


Tabel 5.13 Lanjutan

\begin{tabular}{|c|c|c|c|c|c|c|c|c|c|}
\hline & \multicolumn{2}{|c|}{$\mathrm{N}$} & \multirow[b]{2}{*}{ Mean } & \multirow[b]{2}{*}{ Median } & \multirow[b]{2}{*}{ Mode } & \multirow{2}{*}{$\begin{array}{c}\text { Std. } \\
\text { Deviation }\end{array}$} & \multirow[b]{2}{*}{ Range } & \multirow[b]{2}{*}{ Minimum } & \multirow[b]{2}{*}{ Maximum } \\
\hline & Valid & Missing & & & & & & & \\
\hline $\begin{array}{l}\text { Model-model dan } \\
\text { metode-metode } \\
\text { penetapan harga } \\
\text { (USEF06) }\end{array}$ & 97 & 3 & .72 & 1.00 & 1 & .997 & 4 & -2 & 2 \\
\hline $\begin{array}{l}\text { Integrasi dari } \\
\text { layanan-layanan } \\
\text { umum (EOU05) }\end{array}$ & 97 & 3 & .51 & 1.00 & 1 & 1.226 & 4 & -2 & 2 \\
\hline $\begin{array}{l}\text { Integrasi dari } \\
\text { aplikasi-aplikasi e- } \\
\text { commerce } \\
\text { (USEF07) }\end{array}$ & 97 & 3 & .44 & 1.00 & 1 & 1.283 & 4 & -2 & 2 \\
\hline $\begin{array}{l}\text { Perutean dan } \\
\text { penelusuran } \\
\text { (USEF08) }\end{array}$ & 97 & 3 & .47 & 1.00 & 1 & 1.308 & 4 & -2 & 2 \\
\hline $\begin{array}{l}\text { Akses kepada } \\
\text { dukungan } \\
\text { pelanggan (EOU06) }\end{array}$ & 97 & 3 & .49 & 1.00 & 1 & 1.209 & 4 & -2 & 2 \\
\hline $\begin{array}{l}\text { Kinerja dari } \\
\text { dukungan } \\
\text { pelanggan } \\
\text { (USEF09) }\end{array}$ & 97 & 3 & .32 & 1.00 & 1 & 1.279 & 4 & -2 & 2 \\
\hline $\begin{array}{l}\text { Akses ke sebuah } \\
\text { komunitas virtual } \\
\text { (EOU07) }\end{array}$ & 97 & 3 & .06 & 1.00 & 1 & 1.273 & 4 & -2 & 2 \\
\hline $\begin{array}{l}\text { Keuntungan dari } \\
\text { relasi-relasi di dalam } \\
\text { komunitas (USEF10) }\end{array}$ & 97 & 3 & .12 & 1.00 & 1 & 1.269 & 4 & -2 & 2 \\
\hline $\begin{array}{l}\text { Keuntungan dari } \\
\text { ketersediaan isi di } \\
\text { dalam komunitas } \\
\text { (USEF11) }\end{array}$ & 97 & 3 & .09 & 1.00 & 1 & 1.259 & 4 & -2 & 2 \\
\hline $\begin{array}{l}\text { Pemberdayaan } \\
\text { pelanggan yang } \\
\text { dihasilkan dari } \\
\text { komunitas (USEF12) }\end{array}$ & 97 & 3 & .09 & .00 & 1 & 1.331 & 4 & -2 & 2 \\
\hline $\begin{array}{l}\text { Ketersediaan sistem } \\
\text { (EOU08) }\end{array}$ & 97 & 3 & .99 & 1.00 & 1 & .995 & 4 & -2 & 2 \\
\hline $\begin{array}{l}\text { Desain dari } \\
\text { antarmuka } \\
\text { pengguna (EOU09) }\end{array}$ & 97 & 3 & .91 & 1.00 & 1 & 1.100 & 4 & -2 & 2 \\
\hline $\begin{array}{l}\text { Meningkatkan } \\
\text { produktivitas dengan } \\
\text { menghemat waktu } \\
\text { (USEF13) }\end{array}$ & 97 & 3 & .96 & 1.00 & 1 & 1.020 & 4 & -2 & 2 \\
\hline Interaksi (USEF14) & 97 & 3 & .80 & 1.00 & 1 & 1.151 & 4 & -2 & 2 \\
\hline $\begin{array}{l}\text { Fungsi-fungsi } \\
\text { personalisasi } \\
\text { (USEF15) }\end{array}$ & 97 & 3 & .41 & 1.00 & -1 & 1.297 & 4 & -2 & 2 \\
\hline $\begin{array}{l}\text { Kepercayaan dari } \\
\text { rekan bisnis } \\
\text { (pemasok) } \\
\text { (TRUST1) }\end{array}$ & 97 & 3 & .93 & 1.00 & 1 & .992 & 4 & -2 & 2 \\
\hline $\begin{array}{l}\text { Hal yang dapat } \\
\text { dipercaya dari situs } \\
\text { web dan situasi } \\
\text { legal (TRUST2) }\end{array}$ & 97 & 3 & .95 & 1.00 & 1 & 1.064 & 4 & -2 & 2 \\
\hline
\end{tabular}

a. Multiple modes exist. The smallest value is shown

Terdapat beberapa kesimpulan yang bisa digambarkan pada Tabel 5.13. Situs web pada kolom N valid bernilai 100 (5 situs web x 20 asesor) artinya bahwa 5 situs web (4 situs web lokal dan 1 situs web standar De Facto) seluruhnya dievaluasi 
oleh asesor, Mean (rata-rata hitung) bernilai 3; Median (nilai tengah) bernilai 3; Mode (pemunculan nilai terbanyak) nilai $1^{\text {a }}$ diartikan ditemukannya lebih dari satu nilai terbanyak, nilai yang ditampilkan saat ini adalah nilai terkecilnya; simpangan baku (Standard Deviation) nilai 1.421 menunjukkan derajat konsensus yang luas dari asesor artinya banyak asesor yang memiliki pendapat yang sangat bervariasi atau kurang fokus; Range (jangkauan) dari nilai tertinggi ke nilai terendah yaitu 51 = 4; Minimum (nilai terkecil) bernilai 1 dan Maximum (nilai tertinggi) bernilai 5 . Kolom kriteria N valid bernilai 97 dan missing bernilai 3 artinya bahwa terdapat tiga situs web yang tidak dievaluasi oleh asesor. Kriteria "Struktur isi (EOU2)" satu-satunya kriteria yang tidak pernah memperlihatkan nilai yang rendah. Mean (1.15) menunjukkan "Situs web terstruktur dengan baik untuk kelima toko buku online“; Simpangan baku (Standard Deviation) (0.795) nilai < 1.00 menunjukkan sebagian besar asesor sepakat bahwa "Situs web memang terstruktur dengan baik“; Minimum (-1) menunjukkan tidak ada satupun dari asesor yang menyatakan bahwa situs web sangat tidak terstruktur. Kenyataannya, meskipun balaipustakaonline.com merupakan situs web yang terburuk, tetapi memiliki situs web yang terstruktur. Kriteria "Kemudahan akses dari situs web dan produkproduknya (EOU01)” dan “Kuantitas informasi (EOU03)” juga memperlihatkan hasil yang baik dari asesor terhadap situs web yang dinilai. Kriteria "Akses ke sebuah komunitas virtual (EOU7)” memperoleh penilaian yang terendah dari asesor dengan derajat konsensus sebesar 1.273, artinya asesor banyak yang tidak sepakat pada kriteria tersebut. Missing menunjukkan terdapat situs web yang tidak dievaluasi oleh asesor (hanya 19 orang) yaitu amazon.com (Standar De Facto), erlangga.co.id, dan gramediaonline.com. Kebanyakan distribusi kriteria yang lain menunjukkan ketidaksepakatan dari asesor.

Uraian Analisis Statistik Deskriptif di atas dapat dirangkum sebagai berikut:

- 5 situs web secara keseluruhan dinilai oleh 20 asesor yang berpartisipasi (Valid: 100; Missing: 0),

- Terdapat kriteria pada 3 situs web yang tidak dinilai oleh asesor (Valid: 97; Missing: 3),

- Asesor sepakat dari 4 situs web lokal dan 1 situs web Standar De Facto pada penelitian ini menunjukkan situs web terstruktur dengan baik, situs 
web mudah diakses, produk-produknya dengan mudah dapat ditemukan, dan informasi yang ditampilkan proporsional. Pengembang perangkat lunak pada situs web terkait perlu mempertahankan kinerja pada kriteriakriteria tersebut dan perlu meningkatkan lagi di masa depan agar tetap sesuai dengan ekspektasi konsumen,

- Peneliti mencatat terdapat 5 kriteria dengan kinerja terburuk menurut penilaian asesor yaitu 4 kriteria pada fase Community Component dan 1 kriteria pada Information Phase. Kriteria yang termasuk dalam fase Community Component adalah "Akses ke sebuah komunitas virtual (EOU07) (Mean 0.06)”, ”Keuntungan dari relasi-relasi di dalam komunitas (USEF10) (Mean 0.12)”, ”Keuntungan dari ketersediaan isi di dalam komunitas (USEF11) (Mean 0.09)", dan "Pemberdayaan pelanggan yang dihasilkan dari komunitas (USEF12) (Mean 0.09)”. Hasil Analisis Deskriptif ini mendukung hasil analisis kualitatif dari evaluasi kriteria bahwa asesor menilai tidak penting fase Community Component skor (0.74) pada sektor toko buku online. Pengembang perangkat lunak untuk kondisi saat ini tidak perlu fokus meningkatkan kinerja aplikasi $e$ commerce untuk kriteria di dalam fase Community Component ini, karena ekspektasi konsumen rendah, meskipun derajat konsensus dari asesor bervariasi (Std. Deviation: (EOU07: 1.273), (USEF10: 1.269), (USEF11: 1.259), dan (USEF12: 1.331)), namun nilai rata-ratanya (Mean) tetap cenderung rendah. Terdapat satu kriteria pada Information Phase yang menunjukkan kinerja sangat buruk yaitu "Sistem-sistem rekomendasi (USEF04) (Mean 0.27)”, kriteria ini memberikan rekomendasirekomendasi yang diotomatisasi bagi pelanggan-pelanggan dalam bentuk cross-and up-selling dan collaborative filtering yang diturunkan dari situasi pembelian yang umum dan riwayat transaksi mereka. Menurut peneliti fitur ini belum diintegrasikan pada aplikasi e-commerce yang dinilai untuk 4 situs web lokal sehingga nilainya rendah, namun perlu diperhatikan bahwa hasil evaluasi kriteria menunjukkan bahwa asesor menilai penting kriteria pada Information Phase (1.47) artinya bahwa fitur untuk kriteria "Sistem-sistem rekomendasi (USEF04)” ini perlu dibuat. 


\section{BAB 6 \\ KESIMPULAN DAN SARAN}

Bab ini menguraikan beberapa kesimpulan dan saran-saran yang diperoleh berdasarkan hasil analisis dari bab-bab sebelumnya.

\subsection{Kesimpulan}

Hasil analisis kelima situs web, berdasarkan penilaian evaluasi kriteria dan situs web dengan peringkat pentingnya adalah sebagai berikut: amazon.com (Standar De Facto) (1.32), kutukutubuku.com (Best Practice Profile) (0.73), erlangga.co.id (0.67), gramediaonline.com (0.35), balaipustakaonline.com (0.31). Skala penilaian memiliki jangkauan $(-2 /+2)$ yaitu nilai +1 (baik), nilai +2 (sangat baik), nilai -1 (buruk), sedangkan nilai -2 (sangat buruk). Hanya amazon.com yang memperoleh nilai $>+1$, tertinggi berdasarkan riset ini. Meskipun amazon.com memiliki nilai tertinggi, namun pada penelitian ini hanya dijadikan sebagai Standar De Facto, nilai yang baik secara keseluruhan artinya memenuhi ekspektasi konsumen. kutukutubuku.com (0.73) menjadi situs web lokal terbaik berdasarkan penilaian dan menjadi Best Practice Profile, sedangkan balaipustakaonline.com (0.31) menjadi situs web terburuk (Worst Practice Profile). Meskipun kutukutubuku.com memperoleh nilai tertinggi untuk situs web lokal, namun skala nilai $(+1)$ belum tercapai. Hasil rangkuman dan detail analisis mengindikasikan bahwa keempat situs lokal balaipustakaonline.com, erlangga.co.id, gramediaonline.com, dan kutukutubuku.com belum memenuhi ekspektasi dari konsumen-konsumen di Indonesia.

Analisis dari hasil evaluasi kriteria diperoleh skor setiap fase seperti berikut: Information Phase (1,47), Agreement Phase (1,45), Settlement Phase (1,35), After-Sales Phase (1,42), Community Component (0,68), dan Final Section $(1,47)$. Community Component $(0,68)$ memperoleh nilai terendah artinya konsumen tidak menganggap keberadaan komunitas penting bagi sektor penjualan buku online, sedangkan konsumen menganggap penting kelima fase yang lain. Hasil penelitian 
sebelumnya yang dilakukan oleh Leimstoll, Kurnia, dan Schubert (2005b) pada sektor toko buku online di Australia dan Swiss juga mengindikasikan bahwa Community Component selalu memperoleh nilai terendah. Asesor secara umum tidak merasa puas dengan Community Component pada seluruh situs web yang dievaluasi. Asesor menyebutkan di dalam catatan kualitatif mereka bahwa mereka tidak tertarik untuk berkontribusi dalam komunitas namun lebih memilih berselancar sendiri ke situs-situs web untuk mencari informasi yang mereka inginkan. Penelitian pada tesis ini dari hasil analisis yang diuraikan pada bab 5 juga menunjukkan bahwa Community Component memperoleh nilai terendah pada hasil evaluasi seluruh situs web dan evaluasi kriteria. Bergabung di dalam sebuah komunitas virtual membutuhkan akses Internet yang terus-menerus dan juga menyita waktu yang lebih banyak bagi konsumen untuk berkontribusi. Berdasarkan survei Asia Foundation (2002) menunjukkan bahwa buku-buku bukan termasuk sebagai produk yang bernilai tinggi. Ragam tulis dan baca dari masyarakat Indonesia yang masih rendah juga bisa menjadi salah satu penyebab kurangnya ketertarikan mereka bergabung pada komunitas virtual terutama yang berkaitan dengan buku dan ditambah lagi kebanyakan situs web yang diteliti juga belum mendukung fasilitas untuk terciptanya komunitas bagi pelangganpelanggannya.

\subsection{Saran}

Berikut ini rekomendasi-rekomendasi yang perlu diperhatikan oleh situs-situs web yang diteliti agar dapat memenuhi ekspektasi dari konsumen:

- Rekomendasi: balaipustakaonline.com

Berdasarkan grafik evaluasi strategi balaipustakaonline.com setiap fasenya sangat menjauhi diagonal, Community Component berada di wilayah strategi "improvement necessary", sedangkan Settlement Phase berada pada titik yang netral artinya posisi ini juga tidak mengindikasikan keadaan yang baik terpenuhinya kriteria sesuai ekspektasi konsumen. Jika dilihat lagi per kriteria “Integrasi dari layanan-layanan umum” (skor 0.00), “Integrasi dari aplikasi-aplikasi e-commerce” (skor -0.08), dan "Perutean 
dan penelusuran” (skor 0.08). Kriteria-kriteria ini harus diperbaiki segera, agar ekspektasi konsumen bisa tercapai. Secara umum penilaian situs web balaipustakaonline.com belum memenuhi ekspektasi dari konsumen (0.31).

- Rekomendasi: erlangga.co.id

Erlangga.co.id merupakan penerbit yang komitmen kepada visi dan misinya mengembangkan buku-buku pelajaran dan saat ini juga sudah memperluas tema-tema bukunya kepada bisnis dan pengembangan kepribadian. Evaluasi strategi menunjukkan bahwa secara keseluruhan setiap fase masih menjauhi diagonal. Meskipun berada pada wilayah "maintain strategy", Community Component kembali menunjukkan nilai yang rendah pada situs web lokal, meskipun asesor tidak menilai cukup penting fase ini bagi toko buku online di Indonesia, namun untuk perbaikan ke depan perlu juga dipertimbangkan. Jika dilihat lebih jauh skor kriteria pada Settlement Phase, "Integrasi dari layanan-layanan umum” (skor 0.27), "Integrasi dari aplikasi-aplikasi e-commerce” (skor 0.27), dan "Perutean dan penelusuran” (skor 0.49), sedangkan pada AfterSales Phase kriteria yang tercakup adalah “Akses kepada dukungan pelanggan” (skor 0.63) dan “Kinerja dari dukungan pelanggan” (skor 0.27). Hanya tiga kriteria pertama pada Information Phase yang menunjukkan kinerja yang baik yaitu "Kemudahan akses dari situs web dan produk-produknya” (skor 1.30) "Struktur Isi” (skor 1.21), “Kuantitas informasi” (skor 1.21), dan "Kualitas isi” (skor 0.91). "Desain dari prosedur pemesanan” (skor 0.81) pada salah satu kriteria di dalam Agreement Phase juga mendekati kinerja yang baik. Kriteria-kriteria yang tersebar dalam fase-fase yang belum disebutkan memperoleh nilai yang lebih rendah. Kinerja situs web perlu ditingkatkan dengan mengoptimalkan kriteria-kriteria dengan skor rendah. Situs web secara keseluruhan belum memenuhi ekspektasi dari konsumen (0.67). 
- Rekomendasi: gramediaonline.com

Berdasarkan grafik evaluasi strategi pada situs web gramediaonline.com setiap fasenya sangat menjauhi diagonal, artinya ekspektasi konsumen kepada kinerja situs web gramediaonline.com yang tinggi tidak sesuai dengan kenyataan yang terjadi, Community Component dan Settlement Phase berada di wilayah strategi "improvement necessary", Jika dilihat lagi per kriteria pada Settlement Phase "Integrasi dari layanan-layanan umum” (skor 0.18), “Integrasi dari aplikasi-aplikasi e-commerce” (skor 0.17), dan "Perutean dan penelusuran” (skor -0.18) nilai ini sangat jauh dari dapat dikatakan baik sesuai skala (skala 1 adalah baik). Kriteria yang menunjukkan nilai tertinggi adalah pada Information Phase yaitu pada kriteria "Kemudahan akses dari situs web dan produk-produknya" (skor 1.05), "Ketersediaan sistem” (skor 0.75). Sedangkan pada Final Section yaitu pada kriteria "Kepercayaan dari rekan bisnis (pemasok)” (skor 1.04), dan "Hal yang dapat dipercaya dari situs web dan situasi legal” (skor 1.10) memperoleh nilai yang baik. Kriteria-kriteria ini (skala $>1$ ) harus dipertahankan dan ditingkatkan lagi, sedangkan kriteria yang tidak disebutkan yaitu kriteria dengan skor yang rendah harus segera dioptimalkan agar sesuai dengan harapan konsumen. Saat ini secara umum penilaian situs web gramediaonline.com belum memenuhi ekspektasi dari konsumen (0.35).

- Rekomendasi: kutukutubuku.com

Bagian terakhir dari evaluasi strategi adalah pada toko buku online kutukutubuku.com, dibandingkan dengan rata-rata sektor (Sector Profile) kutukutubuku.com mengungguli nilai pada seluruh fasenya. Agreement Phase memperoleh nilai tertinggi (skor 1.03), disusul dengan Final Section (0.88) dan Information Phase (0.87), namun demikian gambaran grafik menunjukkan penyebaran titik koordinat yang tidak fokus tapi menyebar dan cenderung menjauhi diagonal artinya ekspektasi konsumen kepada kinerja situs web kutukutubuku.com tinggi, namun kenyataan yang terjadi tidak demikian. Community Component, Settlement Phase, dan After-Sales 
Phase merupakan fase-fase yang cenderung menjauhi diagonal. Jika dilihat lebih jauh kriteria-kriteria “Akses ke sebuah komunitas virtual” (skor 0.17), "Keuntungan dari relasi-relasi di dalam komunitas" (skor 0.27), “Keuntungan dari ketersediaan isi di dalam komunitas” (skor 0.14), dan "Pemberdayaan pelanggan yang dihasilkan dari komunitas" (0.10) pada Community Component tidak menunjukkan performa yang baik. Kriteria-kriteria “Integrasi dari layanan-layanan umum” (skor 0.46), “Integrasi dari aplikasi-aplikasi e-commerce” (skor 0.37), dan "Perutean dan penelusuran” (skor 0.46) pada Settlement Phase, dan kriteria-kriteria yang tercakup pada After Sales Phase yaitu "Akses kepada dukungan pelanggan” (skor 0.46) dan “Kinerja dari dukungan pelanggan” (skor 0.26), kedua fase terakhir juga tidak mengindikasikan performa yang baik. Sehingga di setiap kriteria pada Settlement Phase dan After-Sales Phase perlu ditingkatkan pemenuhan kriteria agar sesuai dengan ekspektasi konsumen. Meskipun kutukutubuku.com dalam riset ini menempati urutan pertama dengan skor tertinggi dan menjadi Best Practice Profile, namun hasil analisis kualitatif berdasarkan kepada skor setiap kriteria, fase, dan skor keseluruhan belum bisa memenuhi ekspektasi dari konsumen (0.73).

\subsection{Keterbatasan}

Peneliti menyadari bahwa studi empiris dengan sekumpulan sampel 20 orang asesor hanya dapat merefleksikan gambaran terbatas di dalam sebuah sektor. Penilaian aplikasi e-commerce secara keseluruhan oleh 20 orang dari Indonesia tidaklah bisa mewakili ribuan pengguna web di Indonesia dalam transaksi B2C. Meskipun demikian EWAM adalah proses yang membutuhkan pengetahuan yang tinggi sehingga peneliti tidak bisa meminta sampel secara acak dari orang yang akan melakukan evaluasi. Oleh karena itu situs web yang diuji juga dipilih per sektor untuk menghindari bias yang mungkin terjadi dan diseleksi sebagai pelaku-pelaku bisnis yang serius dalam menjalankan bisnis toko buku online. 
Keberhasilan riset ini sangat ditentukan oleh pemahaman instruksi yang dipelajari oleh asesor pada EWAM tool, keterlibatan asesor secara menyeluruh dan mendalam dalam melakukan penilaian situs web dan evaluasi kriteria pada seluruh fase dalam EWAM, pengalaman asesor sebelumnya dalam transaksi elektronik, dan ketelitian dalam melakukan analisis kualitatif dan kuantitatif deskriptif dengan memperhatikan berbagai aspek dari profil sektor yang dievaluasi dan hukum transaksi elektronik yang berlaku pada saat riset dilakukan.

Penelitian lanjutan bisa dilakukan dengan mengambil beberapa situs web $e$ commerce dalam sektor yang sama yang dipilih secara selektif minimal tiga situs sampai maksimal tujuh situs web (Leimstoll, 2009), semakin banyak hasil evaluasi akan menghasilkan semakin banyak informasi sehingga memberikan petunjuk kriteria-kriteria pada fase-fase tertentu dapat memberikan kontribusi yang lebih besar kepada ekspektasi konsumen. 


\section{DAFTAR PUSTAKA}

Asia Foundation (2002). SMEs and E-Commerce. URL:

http://asiafoundation.org/pdf/SMEsurvey_Indo.pdf. Diakses tanggal 16

Oktober 2009

BPS (2006). Berita Resmi Statistik No. 42/IX/14 Agustus 2006, ’Profil Pemanfaatan Teknologi Informasi oleh Masyarakat. Hasil Survey Sosial Ekonomi Nasional (Susenas) 2005. URL:

http://www.bps.go.id/brs_file/profilti-14agt06.pdf?. Diakses tanggal 14 September 2009

Davis \& Venkatesh (2000). A theoretical extension of the technology acceptance model: Four longitudinal field studies. Management Science. Linthicum: Feb 2000. Vol. 46, Iss. 2; p. 186 (19 pages) URL: http://proquest.umi.com/pqdweb. Tanggal akses 12 November 2009

Deitel H. M., Deitel P.J., and Steinbuhler K. (2001), e-Business \& e-Commerce for Managers, Prentice-Hall, Inc. Upper Saddle River, New Jersey 07458

DigitSmith (2006). E-Commerce Definition. URL:

http://www.digitsmith.com/ecommerce-definition.html. Diakses tanggal 17 Oktober 2009.

Eshun, Elizabeth D. \& Taylor, Theresa (2009). Internet and E-commerce Adoption among SME Non-Traditional Exporters Case Studies of Ghananian Handicraft Exporters. Master Thesis. URL: http://epubl.luth.se/16530187/2009/036/LTU-PB-EX-09036-SE.pdf. Diakses tanggal 10 Juli 2009

ITU (2002). Kretek Internet: Indonesia Case Study. International Telecommunication Union, Geneva, Switzerland. URL: http://www.itu.int/ITU-D/ict/cs/indonesia/material/IDN\%20CS.ZIP. Diakses tanggal 16 Oktober 2009 
Ketel \& Nelson (2008). E-Commerce. URL:

http://searchcio.techtarget.com/sDefinition/0,sid182_gci212029,00.html.

Diakses tanggal 17 Oktober 2009

Kurnia, Schubert, Leimstoll (2005b). An Evaluation of Australian and Swiss E-

Shops in the Grocery Sector, Proceedings of the 38th HICSS Conference,

Hawaii, 2005. URL: http://bas.uni-

koblenz.de/bas/publications.nsf/c5afffd09db54d89c12572180036e1b1/c71d7d

a9f4af8454c1257359004908c0/\$FILE/HICSS_kurnia_et_al_copyright.pdf.

Diakses tanggal 10 Oktober 2009

Kurnia \& Schubert (2004). An Evaluation of On-line Grocery Services in

Australia from a Consumers' Viewpoint. Proceedings of the Twelfth

CollECTeR Workshop on eCommerce, 7./8. May, 2004, Adelaide, Australia.

URL: http://bas.uni-

koblenz.de/bas/publications.nsf/c5afffd09db54d89c12572180036e1b1/29e5

7225ac2257f0c1257359004908a7/\$FILE/Collecter2004_final.pdf.

Diakses tanggal 10 Oktober 2009

Leimstoll, Kurnia \& Schubert (2005a). Selling Books Online: An Evaluation of Australian and Swiss E-Shops, Proceedings of the 18th Bled eConference, eIntegration in Action, Bled, Slovenia, June 6-8 2005. URL: http://bas.unikoblenz.de/bas/publications.nsf/c5afffd09db54d89c12572180036e1b1/833f18 01ba656351c1257359004908ce/\$FILE/40_Leimstoll_Kurnia_Schubert.pdf. Diakses tanggal 10 Oktober 2009

Leimstoll (2009). Communication via e-mail on December $11^{\text {th }}$ and $21^{\text {st }} 2009$

Malhotra \& Galletta (1999). Extending the Technology Acceptance Model to Account for Social Influence: Theoretical Bases and Empirical Validation. Proceedings of the 32nd Hawaii International Conference on System Sciences - 1999. URL: http://www.brint.org/technologyacceptance.pdf. Diakses tanggal 12 November 2009 
Merwe \& Bekker (2003). A Framework and methodology for evaluating ecommerce Web sites. Internet Research; 2003; 13, 5; ABI/INFORM Global. pg. 330. URL: http://proquest.umi.com/pqdweb. Diakses tanggal 10 November 2009.

Purbo, Onno W. (2001). E-Commerce Empowerment for SMEs: Indonesia Case. URL: http://bebas.vlsm.org/v11/onno-eng-1/application/e-commerce/ecommerce-empowerment-for-sme-indonesia-case-01-2001.rtf. Diakses tanggal 17 Oktober 2009.

Schubert (2003). Extended Web Assessment Method (EWAM) - Evaluation of Electronic Commerce Applications from the Customer's Viewpoint, in: International Journal of Electronic Commerce, Vol. 7, No. 2, Winter 20022003. URL: http://bas.unikoblenz.de/bas/publications.nsf/a3f18119c0cb8fe3c12572180036eb5c/5f406 6937bf8a021c1257359004908cc/\$FILE/schubert_ijec_2003.pdf. Diakses tanggal 12 Nov. 2009

Schubert \& Dettling (2002). Extended Web Assessment Method (EWAM) Evaluation Of E-Commerce Applications From The Customer's Viewpoint. Proceedings of the 35th HICSS Conference, Hawaii, 2002. URL: http://bas.unikoblenz.de/bas/publications.nsf/c5afffd09db54d89c12572180036e1b1/f8353 f99cac707ecc1257359004908d6/\$FILE/INCRM04_copyright.pdf. Diakses tanggal 10 Oktober 2009

Schubert \& Leimstoll (2001). The Extended Web Assessment Method (EWAM) applied: do websites for consumer goods stand the test?. Schoop, Mareike; Walczuch, Rita (Hrsg.), Eighth Research Symposium on Emerging Electronic Markets RSEEM 01, 16 - 18 September 2001, Maastricht, The Netherlands, Workshop Papers, S. 53-59, Maastricht: International Institute of Infonomics, 2001. URL: http://bas.unikoblenz.de/bas/publications.nsf/c5afffd09db54d89c12572180036e1b1/ecda9 
19da2ef6f08c1257359004908c9/\$FILE/The\%20Extended\%20Web\%20Asse ssment\%20Method\%20Applied.pdf. Diakses tanggal 10 Oktober 2009

Schubert \& Selz (2001). Measuring the effectiveness of e-commerce Web sites. Barnes, Stuart; Hunt, Brian (Hrsg.), E-Commerce and V-Business: Business Models for Global Success, S. 83-102, Oxford: Butterworth-Heinemann, 2001. URL: http://bas.unikoblenz.de/bas/publications.nsf/c5afffd09db54d89c12572180036e1b1/9578 8907e43283d0c1257359004908c4/\$FILE/webassessment.pdf. Diakses tanggal 10 Oktober 2009

Schubert \& Dettling (2001). Web site evaluation: Do Web applications meet user expectations? Music, consumer goods and e-banking on the test bed. Proceedings of the 14th International Bled Electronic Commerce Conference, Bled, Slovenia, June 25-56, 2001. URL: http://bas.unikoblenz.de/bas/publications.nsf/c5afffd09db54d89c12572180036e1b1/a64f7038 e353a0e3c1257359004908a9/\$FILE/24_Schubert_Dettling_Proceedings.pdf. Diakses tanggal 12 Oktober 2009

Selz \& Schubert (1998). Web Assessment - A Model for the Evaluation and Assessment of Successful Electronic Commerce Applications. Proceedings of the 31st HICSS Conference, Hawaii, "Internet and the Digital Economy Track", Vol. IV, 1998, S. 222-231. URL: http://bas.unikoblenz.de/bas/publications.nsf/c5afffd09db54d89c12572180036e1b1/24a530 fd64a71c8dc1257359004908ac/\$FILE/wahicss98.pdf. Diakses tanggal 10 Oktober 2009

Selz \& Schubert (1997). Web Assessment: Applied to the Agreement and Settlement Phase. Proceedings of the 4th Emerging Markets Symposium, Maastricht, September 1997. URL: http://bas.unikoblenz.de/bas/publications.nsf/c5afffd09db54d89c12572180036e1b1/a267 0f5e5a8642efc125735900490885/\$FILE/9709_dsepsc_maastricht.pdf. Diakses tanggal 5 Oktober 2009 
Schubert, Leimstoll, \& Risch (2006). Classification of Personalization Functions for E-Commerce Applications. Collector 2006. URL:

http://www.collecter2006.unisa.edu.au/Paper\%204\%20Daniel\%20Risch.pdf. Diakses tanggal 12 November 2009

World Internet Users and Population Stats. URL:

http://www.internetworldstats.com/stats.htm. Diakses tanggal 14 September 2009

Yin (2003). Case Study Research: Design and Methods, Third Edition. Sage Publications, Inc. 2455 Teller Road Thousand Oaks, California 91320 


\section{LAMPIRAN}

\section{Lampiran 1 Daftar Singkatan}

$\begin{array}{ll}\text { AMPS } & \text { : Advanced Mobile Phone System } \\ \text { BPP } & \text { : Best Practice Profile } \\ \text { B2B } & \text { : Business to Business } \\ \text { B2C } & \text { : Business to Customer } \\ \text { C2B } & \text { : Customer to Business } \\ \text { C2C } & \text { : Customer to Customer } \\ \text { CCEM } & \text { : Competence Center for Electronic Markets } \\ \text { CoD } & \text { : Cash on Delivery } \\ \text { DFS } & \text { : De Facto Standard } \\ \text { EWAM } & \text { : Extended Web Assessment Method } \\ \text { GSM } & \text { : Global System for Mobile Communications } \\ \text { ICT } & \text { : Information and Communication Technology } \\ \text { IDR } & \text { : Indonesian Rupiah } \\ \text { ISP } & \text { : Internet Service Provider } \\ \text { NMT } & \text { : Nordic Mobile Telephony } \\ \text { SCP } & \text { : Sector Profile } \\ \text { TAM } & \text { : Technology Acceptance Model } \\ \text { TRA } & \text { : Theory of Reasoned Action } \\ \text { UKM } & \text { : Usaha Kecil dan Menengah } \\ \text { URL } & \text { : Uniform Resource Locater } \\ \text { VoIP } & \text { : Voice over Internet Protocol }\end{array}$




\section{Lampiran 2 Formulir Evaluasi Kriteria}

\section{Formulir Evaluasi Kriteria}

Dengan formulir ini Anda mengevaluasi pentingnya setiap kriteria EWAM. Silahkan menyatakan seberapa penting sebuah kriteria bagi sektor yang Anda analisis. Didalam formulir ini pilihan Anda dan artinya selalu berkorespondensi dengan pola berikut:

\begin{tabular}{|c|l|}
\hline Pilihan Anda & Arti \\
\hline++ & Sangat penting \\
\hline+ & Penting \\
\hline- & Kurang penting \\
\hline-- & Tidak penting \\
\hline n.r. & Kriteria tidak dapat diterapkan, tidak relevan \\
\hline
\end{tabular}

Mohon dicatat bahwa Anda bisa menyerahkan formulir evaluasi kriteria hanya setelah mengevaluasi setiap kriteria. Kembali lagi diingatkan, topik-topik Bantuan menjelaskan setiap fase dan setiap kriteria yang menjadi hak Anda.

Jika Anda ingin mencetak kriteria EWAM, silahkan gunakan PDF berikut $\mathrm{Q}^{(566 \mathrm{~KB})}$.

\section{Formulir Evaluasi Kriteria}

Formulir ini menilai pentingnya kriteria EWAM pada sektor Anda

* Required

\section{Sektor:}

Masukkan sektor yang akan dinilai dalam studi ini menilai toko buku online

Penjualan buku online:

\section{Catatan Penting:}

Sebelum Anda mengevaluasi sebuah kriteria, silahkan selalu membaca topik bantuan. Hal ini menjamin bahwa evaluasi Anda dapat dibandingkan dengan evaluasi-evaluasi dari asesor lain. 


\section{Fase Informasi (Information \\ Phase) *}

Didalam Fase Informasi konsumen menginformasikan diri mereka sendiri mengenai produk-produk dan layanan-layanan. Mereka mencari pemasok-pemasok dan persyaratan-persyaratannya

\begin{tabular}{|c|c|c|c|c|c|}
\hline & ++ & + & - & -- & n.r. \\
\hline $\begin{array}{r}\text { Kemudahan akses } \\
\text { dari situs web dan } \\
\text { produk-produknya } \\
\text { (EOU01) }\end{array}$ & 0 & 0 & 0 & 0 & 0 \\
\hline Struktur isi (EOU02) & 0 & 0 & 0 & 0 & 0 \\
\hline $\begin{array}{r}\text { Kuantitas informasi } \\
\text { (EOU03) }\end{array}$ & 0 & 0 & 0 & 0 & 0 \\
\hline Kualitas isi (USEF01) & 0 & 0 & 0 & 0 & 0 \\
\hline $\begin{array}{r}\text { Menyampaikan } \\
\text { manfaat-manfaat dari } \\
\text { harga (USEF02) }\end{array}$ & 0 & 0 & 0 & 0 & 0 \\
\hline $\begin{array}{l}\text { Membundel produk- } \\
\text { produk dan layanan- } \\
\text { layanannya (USEF03) }\end{array}$ & 0 & 0 & 0 & 0 & 0 \\
\hline $\begin{array}{r}\text { Sistem-sistem } \\
\text { rekomendasi } \\
\text { (USEF04) }\end{array}$ & 0 & 0 & 0 & 0 & 0 \\
\hline $\begin{array}{l}\text { Menggunakan } \\
\text { hypermedia } \\
\text { (USEF05) }\end{array}$ & 0 & 0 & 0 & 0 & 0 \\
\hline
\end{tabular}

\section{Fase Kesepakatan (Agreement}

Phase) *

Sasaran utama pada fase kesepakatan adalah proses pemesanan secara keseluruhan. Pelanggan memilih produk-produk yang diinginkan dan menegosiasikan harga dan persyaratan-persyaratannya dengan pemasok. Fase kesepakatan diakhiri dengan sebuah kontrak penjualan yang mengatur spesifikasi-spesifikasi produk juga persyaratan-persyaratan pembayaran dan cara pengirimannya.

\begin{tabular}{|cccccc}
\hline & ++ & + & - & -- & n.r. \\
\hline $\begin{array}{r}\text { Desain dari prosedur } \\
\text { pemesanan (EOUD4) }\end{array}$ & 0 & 0 & 0 & 0 & 0 \\
\hline $\begin{array}{r}\text { Model-model dan } \\
\text { metode-metode } \\
\text { penetapan harga } \\
(\text { USEFO6) }\end{array}$ & 0 & 0 & 0 & 0 & 0 \\
\hline
\end{tabular}




\section{Fase Penyelesaian (Settlement} Phase) *

Selama Fase Penyelesaian produk-produk yang dipesan dikirim kepada konsumen dan proses pembayaran dipenuhi. Layanan-layanan umum dan integrasi sistem-sistem informasi dari pemasokpemasok dan konsumen-konsumen dapat mendukung proses ini secara efektif. Fungsi-fungsi perutean dan penelusuran memungkinkan untuk mengecek terpenuhinya proses ini.

\begin{tabular}{|c|c|c|c|c|c|}
\hline & ++ & + & - & -- & n.r. \\
\hline $\begin{array}{r}\text { Integrasi dari layanan- } \\
\text { layanan umum } \\
\text { (EOU05) }\end{array}$ & 0 & 0 & 0 & 0 & 0 \\
\hline $\begin{array}{r}\text { Integrasi dari aplikasi- } \\
\text { aplikasi e-commerce } \\
\text { (USEF07) }\end{array}$ & 0 & 0 & 0 & 0 & 0 \\
\hline $\begin{array}{r}\text { Perutean dan } \\
\text { penelusuran } \\
\text { (USEF08) }\end{array}$ & 0 & 0 & 0 & 0 & 0 \\
\hline
\end{tabular}

\section{Fase Setelah-Penjualan} (After-Sales Phase) *

Tergantung pada definisi istilah, Fase After-Sales adalah bukan bagian dari proses transaksi didalam arti kata yang sebenarnya. Fase ini mengikuti proses transaksi dengan tujuan utama membangun hubungan jangka panjang kepada pelanggan dengan melayani pelanggannya dengan baik.

\begin{tabular}{|cccccc|}
\hline & ++ & + & - & -- & n.r. \\
\hline $\begin{array}{r}\text { Akses kepada } \\
\text { dukungan pelanggan } \\
\text { (EOUD6) }\end{array}$ & 0 & 0 & 0 & 0 & 0 \\
\hline $\begin{array}{r}\text { Kinerja dari dukungan } \\
\text { pelanggan (USEF09) }\end{array}$ & 0 & 0 & 0 & 0 & 0 \\
\hline
\end{tabular}




\section{Komponen Komunitas (Community Component) *}

Komponen Komunitas terdiri dari empat kriteria evaluasi, menilai manfaat-manfaat dari komunitaskomunitas virtual. Komunitas-komunitas virtual menyediakan kesempatan untuk membangun hubungan antara pelanggan-pelanggan dan calon pembeli. Hubungan ini penting dalam mendukung pertukaran informasi dan pengalaman-pengalaman antara anggota-anggota komunitas.

\begin{tabular}{|cccccc|}
\hline & ++ & + & - & -- & n.r. \\
\hline $\begin{array}{r}\text { Akses ke sebuah } \\
\text { komunitas virtual } \\
\text { (EOUD7) }\end{array}$ & 0 & 0 & 0 & 0 & 0 \\
\hline $\begin{array}{r}\text { Keuntungan dari } \\
\text { relasi-relasi didalam } \\
\text { komunitas (USEF10) }\end{array}$ & 0 & 0 & 0 & 0 & 0 \\
$\begin{array}{r}\text { Keuntungan dari } \\
\text { ketersediaan isi }\end{array}$ & 0 & 0 & 0 & 0 & 0 \\
$\begin{array}{r}\text { didalam komunitas } \\
\text { (USEF11) }\end{array}$ & 0 & 0 & 0 & 0 & 0 \\
\hline $\begin{array}{r}\text { Pemberdayaan } \\
\text { pelanggan yang } \\
\text { dihasilkan dari }\end{array}$ & & & & \\
\hline komunitas (USEF12)
\end{tabular}

\section{Bagian Akhir (Final Section) *}

Di bawah judul "Bagian Akhir (Final Section)" kriteria evaluasi yang berbeda dikelompokan, Kriteriakriteria tersebut relevan kepada lebih dari satu fase. Kriteria-kriteria ini direlasikan kepada desain antarmuka pengguna dan kepada aspek "kepercayaan (trust)".

\begin{tabular}{rccccc}
\hline & ++ & + & - & -- & n.r. \\
\hline $\begin{array}{r}\text { Ketersediaan sistem } \\
\text { (EOU08) }\end{array}$ & 0 & 0 & 0 & 0 & 0 \\
\hline $\begin{array}{r}\text { Desain dari } \\
\text { antarmuka penguna } \\
\text { (EOUD) }\end{array}$ & 0 & 0 & 0 & 0 & 0 \\
$\begin{array}{r}\text { Meningkatkan } \\
\text { produktivitas dengan } \\
\text { menghemat waktu } \\
\text { (USEF13) }\end{array}$ & 0 & 0 & 0 & 0 & 0 \\
$\begin{array}{r}\text { Interaksi (USEF14) } \\
\begin{array}{r}\text { Fungsi-fungsi } \\
\text { personalisasi } \\
\text { (USEF15) }\end{array}\end{array}$ & 0 & 0 & 0 & 0 & 0 \\
\hline $\begin{array}{r}\text { Kepercayaan dari } \\
\text { rekan bisnis }\end{array}$ & 0 & 0 & 0 & 0 & 0 \\
$\begin{array}{r}\text { (pemasok) (TRUST1) } \\
\text { Hal yang dapat }\end{array}$ & 0 & 0 & 0 & 0 \\
$\begin{array}{r}\text { dipercaya dari situs } \\
\text { web dan situasi legal } \\
\text { (TRUST2) }\end{array}$ & 0 & 0 & 0 & 0 & 0 \\
\hline
\end{tabular}


Pengalaman Internet Anda: *

(Silahkan pilih) M

Silahkan tuliskan nama Anda (nama depan, nama belakang) dan nama user-EWAM Anda:

\section{Nama : *}

(Nama depan dan nama belakang)

Nama user: *

Pilih dari daftar sesuai nama user Anda

Alamat e-mail Anda:

Submit 


\title{
Lampiran 3 Formulir Evaluasi Situs Web
}

\section{Formulir Evaluasi Situs Web}

\begin{abstract}
Formulir Evaluasi Situs Web, Menilai Kehebatan Situs Web
Dengan formulir EWAM interaktif Anda menganalisis dan menilai situs-situs web e-commerce. Penilaian Anda berdasarkan kepada 26 kriteria yang didefinisikan sebelumnya yang dikelompokkan kedalam fase-fase transaksi dari pasar elektronika (Fase Informasi (Information Phase), Fase Kesepakatan (Agreement Phase), Fase Penyelesaian (Settlement Phase), dan Fase Setelah-Penjualan (After-Sales Phase)). Sebagai tambahan, beberapa kriteria membangun dua kelompok lain: Komponen Komunitas (Community Component) dan Bagian Akhir (Final Section). Topik-topik Bantuan menjelaskan setiap fase dan setiap kelompok dari kriteria.
\end{abstract}

Kriteria adalah milik satu dari kategori-kategori "Ease of Use" (EOU01-08), "Usefulness" (USEF01-15) atau "Trust" (TRUST1-2). Penjelasan detail dari sebuah kriteria, silahkan klik kriteria. Mohon dicatat bahwa Anda bisa menyerahkan formulir evaluasi hanya setelah mengevaluasi setiap kriteria.

Jika Anda ingin mencetak kriteria EWAM, silahkan menggunakan PDF berikut ini (565 KB).

Situs web aplikasi e-commerce yang akan dievaluasi yaitu:

- Situs web 1: http://www,amazon.com (Toko Buku Online)

- Situs web 2: http://www.gramediaonline.com (Gramedia Online)

- Situs web 3: http://www,erlangga.co.id (Penerbit Erlangga)

- Situs web 4: http://balaipustakaonline.com (Penerbit Balai Pustaka)

- Situs web 5: http://www.kutukutubuku.com (Toko buku Online)

Klik pada daftar link situs web yang akan dievaluasi di atas dan lengkapi Formulir Penilaian Situs Web di bawah ini:

\section{Formulir Penilaian Situs Web}

Formulir ini menilai kehebatan dari situs-situs web yang dievaluasi

* Required

URL dari situs Web yang akan dinilai: *

Pilih situs buku yang akan dinilai $\mathrm{Y}$

\section{Sektor:}

Masukkan sektor yang akan dinilai dalam studi ini menilai toko buku online Penjualan buku online [

\section{Catatan Penting:}

Sebelum Anda mengevaluasi sebuah kriteria, silahkan selalu membaca topik bantuan. $\mathrm{Hal}$ ini menjamin bahwa evaluasi Anda dapat dibandingkan dengan evaluasi-evaluasi dari asesor lain. 


\begin{tabular}{|c|c|c|c|c|c|}
\hline $\begin{array}{l}\text { 1. Fase Informasi (I } \\
\text { Didalam Fase Inform } \\
\text { produk-produk dan la } \\
\text { persyaratan-persyara }\end{array}$ & $\begin{array}{l}\text { on } \mathbf{P} \\
\text { men } \\
\text { anar }\end{array}$ & $\begin{array}{l}\text { * } \\
\text { inforr } \\
\text { eka } r\end{array}$ & $\begin{array}{l}\text { an dir } \\
\text { ri per }\end{array}$ & -pen & $\begin{array}{l}\text { mengenai } \\
\text { dan }\end{array}$ \\
\hline & ++ & + & - & -- & n.r. \\
\hline $\begin{array}{r}\text { Kemudahan akses } \\
\text { dari situs web dan } \\
\text { produk-produknya } \\
\text { (EOU01) }\end{array}$ & 0 & 0 & 0 & 0 & 0 \\
\hline $\begin{array}{l}\text { Struktur isi } \\
\text { (EOU02) }\end{array}$ & 0 & 0 & 0 & 0 & 0 \\
\hline $\begin{array}{r}\text { Kuantitas informasi } \\
\text { (EOU03) }\end{array}$ & 0 & 0 & 0 & 0 & 0 \\
\hline $\begin{array}{l}\text { Kualitas isi } \\
\text { (USEF01) }\end{array}$ & 0 & 0 & 0 & 0 & 0 \\
\hline $\begin{array}{l}\text { Menyampaikan } \\
\text { manfaat-manfaat } \\
\text { dari harga } \\
\text { (USEF02) }\end{array}$ & 0 & 0 & 0 & 0 & 0 \\
\hline $\begin{array}{r}\text { Membundel } \\
\text { produk-produk dan } \\
\text { layanan- } \\
\text { layanannya } \\
\text { (USEF03) }\end{array}$ & 0 & 0 & 0 & 0 & 0 \\
\hline $\begin{array}{r}\text { Sistem-sistem } \\
\text { rekomendasi } \\
\text { (USEF04) }\end{array}$ & 0 & 0 & 0 & 0 & 0 \\
\hline $\begin{array}{l}\text { Menggunakan } \\
\text { hypermedia } \\
\text { (USEF05) }\end{array}$ & 0 & 0 & 0 & 0 & 0 \\
\hline
\end{tabular}

\section{Fase Kesepakatan (Agreement Phase) *}

Sasaran utama pada fase kesepakatan adalah proses pemesanan secara keseluruhan. Pelanggan memilih produk-produk yang diinginkan dan menegosiasikan harga dan persyaratan-persyaratannya dengan pemasok. Fase kesepakatan diakhiri dengan sebuah kontrak penjualan yang mengatur spesifikasi-spesifikasi produk juga persyaratan-persyaratan pembayaran dan cara pengirimannya.

$\begin{array}{rccccc}\begin{array}{r}\text { Desain dari } \\ \text { prosedur }\end{array} & ++ & + & - & -- & \text { n.r. } \\ \begin{array}{r}\text { pemesanan } \\ \text { (EOUD4) }\end{array} & 0 & 0 & 0 & 0 & 0 \\ \begin{array}{r}\text { Model-model dan } \\ \text { metode-metode }\end{array} & 0 & 0 & 0 & 0 & 0 \\ \begin{array}{r}\text { penetapan harga } \\ \text { (USEFO6) }\end{array} & & & & & \end{array}$




\section{Fase Penyelesaian (Settlement Phase) *}

Selama Fase Penyelesaian produk-produk yang dipesan dikirim kepada konsumen dan proses pembayaran dipenuhi. Layanan-layanan umum dan integrasi sistemsistem informasi dari pemasok-pemasok dan konsumen-konsumen dapat mendukung proses ini secara efektif. Fungsi-fungsi perutean dan penelusuran memungkinkan untuk mengecek terpenuhinya proses ini.

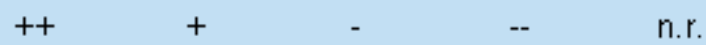

$\begin{array}{rlllll}\begin{array}{r}\text { Integrasi dari } \\ \text { layanan-layanan } \\ \text { umum (EOU05) }\end{array} & 0 & 0 & 0 & 0 & 0 \\ \begin{array}{r}\text { Integrasi dari } \\ \text { aplikasi-aplikasi } \\ \text { e-commerce } \\ \text { (USEF07) }\end{array} & 0 & 0 & 0 & 0 & 0 \\ \begin{array}{r}\text { Perutean dan } \\ \text { penelusuran } \\ \text { (USEF08) }\end{array} & 0 & 0 & 0 & 0 & 0\end{array}$

\section{Fase Setelah-Penjualan (After-Sales Phase) *}

Tergantung pada definisi istilah, Fase After-Sales adalah bukan bagian dari proses transaksi didalam arti kata yang sebenarnya. Fase ini mengikuti proses transaksi dengan tujuan utama membangun hubungan jangka panjang kepada pelanggan dengan melayani pelanggannya dengan baik.
$++$
$+$
$\begin{array}{ll}- & \text { n.r. }\end{array}$

Akses kepada dukungan pelanggan (EOUD6)

O

O

O

O

0

Kinerja dari

dukungan

pelanggan

(USEF09) 


\section{Komponen Komunitas (Community Component) *}

Komponen Komunitas terdiri dari empat kriteria evaluasi, menilai manfaat-manfaat dari komunitas-komunitas virtual. Komunitas-komunitas virtual menyediakan kesempatan untuk membangun hubungan antara pelanggan-pelanggan dan calon pembeli. Hubungan ini penting dalam mendukung pertukaran informasi dan pengalamanpengalaman antara anggota-anggota komunitas.

\begin{tabular}{|c|c|c|c|c|c|}
\hline & ++ & + & - & -- & n.r. \\
\hline $\begin{array}{r}\text { Akses ke sebuah } \\
\text { komunitas virtual } \\
\text { (EOU07) }\end{array}$ & 0 & 0 & 0 & 0 & 0 \\
\hline $\begin{array}{r}\text { Keuntungan dari } \\
\text { relasi-relasi } \\
\text { didalam komunitas } \\
\text { (USEF10) }\end{array}$ & 0 & 0 & 0 & 0 & 0 \\
\hline $\begin{array}{r}\text { Keuntungan dari } \\
\text { ketersediaan isi } \\
\text { didalam komunitas } \\
\text { (USEF11) }\end{array}$ & 0 & 0 & 0 & 0 & 0 \\
\hline $\begin{array}{r}\text { Pemberdayaan } \\
\text { pelanggan yang } \\
\text { dihasilkan dari } \\
\text { komunitas } \\
\text { (USEF12) }\end{array}$ & 0 & 0 & 0 & 0 & 0 \\
\hline
\end{tabular}




\begin{tabular}{|c|c|c|c|c|c|}
\hline \multicolumn{6}{|c|}{$\begin{array}{l}\text { Di bawah judul "Bagian Akhir (Final Section)" kriteria evaluasi yang berbeda } \\
\text { dikelompokan, Kriteria-kriteria tersebut relevan kepada lebih dari satu fase. Kriteria- } \\
\text { kriteria ini direlasikan kepada desain antarmuka pengguna dan kepada aspek } \\
\text { "kepercayaan (trust)". }\end{array}$} \\
\hline & ++ & + & - & -- & n.r. \\
\hline $\begin{array}{l}\text { Ketersediaan } \\
\text { sistem (EOU08) }\end{array}$ & 0 & 0 & 0 & 0 & 0 \\
\hline $\begin{array}{r}\text { Desain dari } \\
\text { antarmuka } \\
\text { pengguna (EOU09) }\end{array}$ & 0 & 0 & 0 & 0 & 0 \\
\hline $\begin{array}{r}\text { Meningkatkan } \\
\text { produktivitas } \\
\text { dengan } \\
\text { menghemat waktu } \\
\text { (USEF13) }\end{array}$ & 0 & 0 & 0 & 0 & 0 \\
\hline Interaksi (USEF14) & 0 & 0 & 0 & 0 & 0 \\
\hline $\begin{array}{l}\text { Fungsi-fungsi } \\
\text { personalisasi } \\
\text { (USEF15) }\end{array}$ & 0 & 0 & 0 & 0 & 0 \\
\hline $\begin{array}{r}\text { Kepercayaan dari } \\
\text { rekan bisnis } \\
(\text { pemasok) } \\
(\text { TRUST1) }\end{array}$ & 0 & 0 & 0 & 0 & 0 \\
\hline $\begin{array}{l}\text { Hal yang dapat } \\
\text { dipercaya dari } \\
\text { situs web dan } \\
\text { situasi legal } \\
\text { (TRUST2) }\end{array}$ & 0 & 0 & 0 & 0 & 0 \\
\hline
\end{tabular}


Pengalaman Internet Anda: *

(Silahkan pilih)

Silahkan tuliskan nama Anda (nama depan, nama belakang) dan nama user-EWAM Anda:

Nama : *

(Nama depan dan nama belakang)

Nama user: *

Pilih dari daftar sesuai nama user Anda M

Alamat e-mail Anda:

Submit 
Lampiran 4 Tampilan EWAM Tool

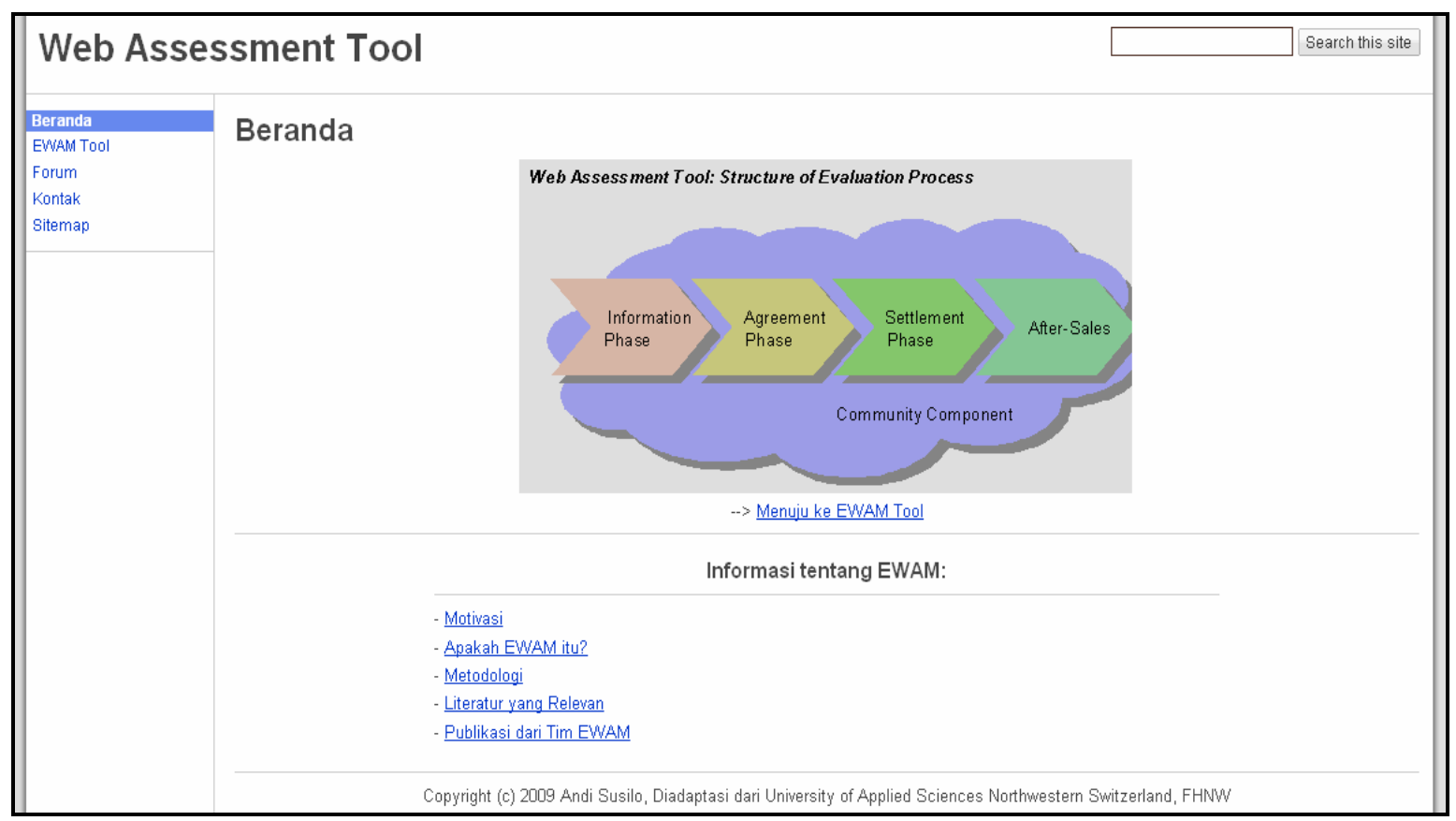

\begin{tabular}{|c|c|c|c|}
\hline \multicolumn{3}{|c|}{ Web Assessment Tool } & Search this site \\
\hline $\begin{array}{l}\text { Beranda } \\
\text { EWAM Tool }\end{array}$ & \multicolumn{3}{|c|}{ EWAM Tool } \\
\hline $\begin{array}{l}\text { Forum } \\
\text { Kontak } \\
\text { Sitemap }\end{array}$ & \multirow{2}{*}{\multicolumn{3}{|c|}{$\begin{array}{l}\text { Mulai dengan evaluasi Anda } \\
\text { EWAM didasarkan kepada dua formulir vealuasi interaktiff. Pergunakanlah formulirformulir ini untuk penilaian Anda kepada situs-situs web yang akan diuji. Jika } \\
\text { Anda ingin diinformasikan mengenai hasil dari studi ini, mohon lengkapi alamat e-mail Anda di bagian akhir dari formulir evaluasi. Ketika menggunakan EWAM, } \\
\text { mohon ikutilah rekomendasi-rekomendasi yang diberikan. } \\
\text { Rekomendasi-rekomendasi bagi analisis sebuah situs web dengan EWAM: }\end{array}$}} \\
\hline \multirow[t]{6}{*}{ Edit sidebar } & & & \\
\hline & Tahap 1 & Silahkan membaca INSTRUKSI untuk menggunakan formulir evaluasi pertama kali & $\underline{\text { INSTRUKSI }}$ \\
\hline & Tahap 2 & Lengkapilah FORMULIR EVALUASI SITUS WEB untuk setiap situs web yang dinilai & $\begin{array}{l}\text { FORMULIR EVALUASI } \\
\text { SITUS WEE }\end{array}$ \\
\hline & Tahap 3 & $\begin{array}{l}\text { Setelah itu, silahkan mengisi FORMULIR EVALUASI KRITERIA dan berikanlah kepada kami pendapat Anda } \\
\text { makna pentingnya kriteria secara tunggal bagi sektor yang Anda nilai }\end{array}$ & $\begin{array}{l}\text { FORMULIR EVALUASI } \\
\text { KRITERIA }\end{array}$ \\
\hline & \multicolumn{3}{|c|}{$<$ - kembali } \\
\hline & \multicolumn{3}{|c|}{ Copyright (c) 2009 Andi Susilo, Diadaptasi dari University of Applied Sciences Northwestern Switzerland, FHNW } \\
\hline
\end{tabular}




\section{Lampiran 5 Kriteria Penilaian Web}

\section{EOU01 Kemudahan akses dari situs web dan produk-produknya}

Pertanyaan: Apakah mudah untuk menemukan situs web?

\begin{tabular}{|c|c|} 
Pilihan Anda & Arti yang mungkin \\
\hline++ & Sangat mudah ditemukan, URL sangat mudah diingat \\
\hline+ & Mudah ditemukan, URL mudah diingat \\
\hline- & Sulit untuk ditemukan, URL sulit diingat \\
\hline-- & Sangat sulit untuk ditemukan, URL sangat sulit diingat \\
\hline n.r. & Kriteria tidak dapat diterapkan, tidak relevan
\end{tabular}

Deskripsi:

1. Gunakan metatags

Sebuah prasyarat bagi keberhasilan aktivitas e-commerce adalah bahwa kelompok target konsumen dapat menemukan penawaran dengan mudah. Pencarian biasanya dilakukan dengan sebuah search engine. Entri pada search engine diarahkan oleh yang sering disebut "metatags", yaitu mendeskripsikan isi dari sebuah situs web. Sebagai tambahan kepada deskripsi yang penuh arti, metatags ini adalah berada di atas semua kata-kata kuncinya. Sehingga pelanggan bisa menemukan situs web, kriteria pencarian dari pembeli potensial manapun seharusnya bisa diantisipasi.

\section{Gunakan nama merk}

Ketika sedang mencari penawaran-penawaran di Internet, mesin-mesin pencari dan agen-agen perangkat lunak memiliki sebuah aturan agar tidak boleh menguntungkan merk tertentu apapun. Sebagai konsekuensinya pemasok-pemasok dengan sebuah merk yang lemah tidak perlu merasa rugi jika seorang pengguna dengan tanpa mengenal merk mencari dari sebuah mesin atau agen. Bagaimanapun juga, jika pemasok-pemasok memiliki merk yang kuat, mereka seharusnya juga mengambil keuntungan dari Internet. Misalnya mereka dapat menggunakan URL yang mengikutsertakan nama merk mereka (misalnya www.aeroflyhobbies.com dengan sebuah link ke situs web FASI). Kondisi ini diasumsikan bahwa pengguna-pengguna akan memasukkan nama merk yang dikenal ke dalam browser mereka sebagai sebuah Uniform Resource Locater (URL).

Situasi ideal dapat terlihat seperti ini:

- $\quad$ Alamat Internet (URL) mudah diingat dan sederhana ketika diketikkan.

- Penawaran akan dikenal dengan mengarahkan mesin-mesin pencari atau agen-agen perangkat lunak.

- Mekanisme-mekanisme Pull: penawaran dari sebuah pemasok dikaitkan ke area-area yang lain di dalam WWW saat kelompok target bergerak. Ini membutuhkan pemasok untuk mengenal profil yang tepat dari target pasarnya.

- Penawaran Internet membangun sebuah kekuatan, merk yang dikenal. 


\section{EOU02 Struktur isi}

Pertanyaan: Bagaimana Anda mengevaluasi struktur isi?

\begin{tabular}{|c|c|}
\hline Pilihan Anda & Arti yang mungkin \\
\hline++ & Isi terstruktur dengan sangat baik \\
\hline+ & Isi terstruktur dengan baik \\
\hline- & Isi kurang terstruktur \\
\hline-- & Isi sangat tidak terstruktur \\
\hline n.r. & Kriteria tidak dapat diterapkan, tidak relevan \\
\hline
\end{tabular}

Deskripsi:

Kriteria "struktur isi" meliputi presentasi sama baiknya dengan logika dibelakang konstruksi situs web. Pemasok dihadapi dengan tantangan mempresentasikan seorang pengunjung dengan situs web yang terstruktur dengan baik dengan penataan isi yang jelas. Padahal pengguna baru seharusnya bisa menemukan cara mereka di sekitarnya secara cepat, pengguna-pengguna yang lebih berpengalaman seharusnya diberikan kesempatan untuk menyesuaikan situsnya dengan kebutuhan-kebutuhan individual mereka (misalnya memilih elemen-elemen yang dibutuhkan pada homepage).

Situasi ideal bisa kelihatan seperti ini:

- Pengunjung menemukan isi yang secara jelas diletakkan dari perspektif individual mereka.

- Manfaat-manfaat spesial dari sebuah situs web kepada pelanggan: Produk-produk baru, penawaran-penawaran dan persyaratan-persyaratan khusus yang bisa dilihat secara langsung.

- Bantuan navigasi membuat akses kepada isi menjadi lebih mudah. Contoh: Produkproduk bisa ditata kedalam kategori-kategori kelompok-kelompok produk, harga atau konteks ("ulang tahun anak-anak").

- Informasi inti tentang isu-isu penting kepada pengunjung ditempatkan secara baik, dan bisa ditemukan dengan mudah dan cepat; informasi detail tambahan bisa dipanggil secara cepat.

- Fungsi-fungsi pencarian pada situs bekerja cepat dan efektif.

- Informasi mengenai perusahaan (organisasi, lokasi, kontak, dan lain-lain) siap untuk diakses. 


\section{EOU03 Kuantitas informasi}

Pertanyaan: Bagaimana mengevaluasi kuantitas informasi yang disediakan?

\section{Pilihan Anda Arti yang mungkin}

$++\quad$ Kuantitas informasi sangat baik terukur.

$+\quad$ Kuantitas informasi terukur dengan baik.

Halaman-halaman yang dimuat terlalu banyak secara terpisah, atau sesekali terdapat kekurangan informasi.

Halaman-halaman secara umum dimuat terlalu banyak, atau terdapat sebuah kekurangan yang secara umum dari informasi.

n.r. $\quad$ Kriteria tidak dapat diterapkan, tidak relevan

Deskripsi:

Di Internet hampir tidak ada batasan kepada informasi ketika sebuah pemasok bisa menyediakannya. Bagaimanapun juga, sebagai tambahan mendeskripsikan produk-produk dan layanan-layanan perusahaan, maksudnya adalah agar tidak menuju ke setiap kemungkinan isu dalam detail terkecil. Pemasok dihadapi dengan tantangan menyediakan kepada pengunjungpengunjungnya kuantitas informasi yang masuk akal. Pengunjung-pengunjung seharusnya menerima seluruh informasi yang relevan tanpa dibanjiri terlalu banyak.

Untuk mengukur jumlah yang benar dari informasi sangat sulit, ketika pengunjung-pengunjung membutuhkan perbedaan jumlah informasi tergantung kepada kondisi pengetahuan mereka sendiri dan situasi khusus mereka.

Situasi ideal bisa kelihatan seperti berikut ini:

- Kebutuhan-kebutuhan informasi dari pengunjung bisa terpenuhi tanpa harus dengan membanjiri informasi.

- Perusahaan dan layanan-layanan dan produk-produknya dideskripsikan dalam detail yang mencukupi atau sesuai.

- Jumlah informasi terukur sehingga pengunjung-pengunjung tidak kehilangan gambaran ikhtisarnya. 


\section{USEF01 Kualitas isi}

Pertanyaan: Apakah kualitas isi sesuai dengan ekspektasi-ekspektasi Anda?

\begin{tabular}{cl} 
Pilihan Anda & Arti yang mungkin \\
\cline { 2 - 2 }++ & Kualitas isi sangat baik \\
\hline+ & Kualitas isi baik \\
- & Kualitas isi buruk \\
-- & Kualitas isi sangat buruk \\
n.r. & Kriteria tidak dapat diterapkan, tidak relevan
\end{tabular}

Deskripsi:

Konsumen-konsumen online mengunjungi sebuah situs web karena mereka mengharapkan sebuah isi tertentu. Mereka mencari informasi, yang ingin ditunjukkan atau ingin menyelesaikan sebuah transaksi. Tugas pemasok adalah untuk menyajikan kepada pengunjung isi yang dipersiapkan dengan baik dan penuh arti.

Menyajikan informasi pada Internet adalah secara normal lebih murah daripada menyajikannya secara tercetak. Lebih jauh, informasi online bisa dimutakhirkan dengan lebih mudah dan cepat. Konsekuensinya, tanpa terlalu banyak biaya dan usaha kepada pemasok, pelanggan bisa menurunkan keuntungan-keuntungan tambahan dari detailnya, dan di atas semuanya itu, deskripsi yang dimutakhirkan secara berkesinambungan dari produk-produk dan layanan-layanan. Petunjukpetunjuk yang teratur kepada pemutakhiran isi yang penting memberi semangat kepada pelanggan untuk kembali kepada situs web.

Situasi ideal bisa dilihat seperti berikut:

- Kualitas isi tinggi: Sebuah deskripsi yang tanpa cacat dari perusahaan dan layananlayanan dan produk-produknya harus secara berkesinambungan dimutakhirkan.

- Foto-foto dan gambar-gambar digunakan secara bijaksana untuk membuat deskripsideskripsi lebih visual.

- Isi berisi informasi penting tambahan yang dibandingkan dengan sumber-sumber lain.

- Perbandingan harga dengan kompetitor menawarkan kemungkinan-kemungkinan. 


\section{USEF02 Menyampaikan manfaat-manfaat dari harga}

Pertanyaan: Apakah keuntungan-keuntungan biaya pemasok dalam terminologi harga yang lebih murah disampaikan kepada pelanggan?

\begin{tabular}{cc} 
Pilihan Anda & Arti yang mungkin \\
\hline++ & Harga secara jelas lebih murah daripada di dalam toko "bricks-and-mortar”. \\
+ & Harga sedikit lebih rendah daripada di dalam toko "bricks-and-mortar”. \\
- & Manfaat-manfaat biaya tidak disampaikan kepada pelanggan. \\
-- & Harga yang lebih tinggi daripada toko "bricks-and-mortar”. \\
n.r. & Kriteria tidak diterapkan, tidak relevan.
\end{tabular}

Deskripsi:

Bisnis online seringkali mengarah kepada keuntungan biaya; membuat sebuah penawaran online pada umumnya lebih murah daripada membuka toko "bricks-and-mortar". Keuntungankeuntungan biaya didasarkan kepada tabungan pada premis-premis dan karyawan-karyawan dalam area penjualan. Presentasi isi pada Internet jauh lebih murah daripada versi tercetak. Dengan barang-barang virtual (misalnya perangkat lunak) distribusi biaya lebih murah lagi.

Pengurangan biaya potensial bisa digunakan oleh pemasok untuk memperbaiki hasil operasinya, atau, sebagai alternatif bisa disampaikan kepada pelanggan. Perusahaan apapun ingin mempertahankan pelanggan-pelanggannya dengan sukses dan akan melakukannya dengan baik untuk menyampaikan keuntungan-keuntungan harga yang lebih murah kepada mereka.

Situasi ideal bisa terlihat seperti berikut:

- Keuntungan-keuntungan biaya diabndingkan dengan toko-toko fisik yang disampaikan kepada pelanggan dalam bentuk harga-harga yang lebih murah.

- Biaya-biaya surat tidak membuat pembelian secara online lebih mahal daripada toko-toko fisik. 


\section{USEF03 Pembundelan produk-produk dan layanan-layanan}

Pertanyaan: Dapatkah produk-produk dan layanan-layanan berguna untuk dibundel secara bersama?

\begin{tabular}{cl} 
Pilihan Anda & Arti yang mungkin \\
\hline++ & Pembundelan produk-produk dan layanan-layanan sangat baik \\
\hline+ & Pembundelan produk-produk dan layanan-layanan dilakukan dengan baik \\
\hline- & Pembundelan sulit dilakukan pada produk-produk dan layanan-layanan \\
-- & $\begin{array}{l}\text { Tidak ada pembundelan produk-produk dan layanan-layanan, meskipun } \\
\text { diinginkan }\end{array}$ \\
& $\begin{array}{l}\text { Kriteria tidak diterapkan, tidak relevan (Pembundelan tidak perlu } \\
\text { dipertimbangkan.) }\end{array}$
\end{tabular}

Deskripsi:

Pada pembelian sebuah produk seorang pelanggan sering memperoleh layanan-layanan yang saling melengkapi. Juga produk-produknya sendiri sering terdiri dari beberapa bagian dari produkproduk atau komponen-komponen yang dibundel bersama-sama untuk memenuhi kebutuhankehutuhan pelanggannya. Penawaran ini bisa juga dibuat oleh pemasok pihak ketiga (misalnya ketika Anda membeli sebuah mobil apakah Anda membutuhkan asuransi atau bantuan keuangan?)

Situs-situs web yang baik menawarkan pelanggan-pelanggannya bantuan dalam meletakkan produk-produk mereka bersama-bersama dan memilih layanan-layanan komplementer (juga oleh pemasok-pemasok pihak ketiga). Diantaranya bantuan-bantuan yang digunakan adalah, misalnya, konfigurasi-konfigurasi produk, tool-tool perencanaan, daftar produk, memunculkan gambargambar atau sebuah presentasi dari produk di dalam isi situs web.

Sebuah prasyarat agar pembundelan berfungsi dengan baik adalah pertama-tama penawaran yang cocok antara produk-produk dan layanan-layanan komplementernya, seluruhnya harus dengan deskripsi yang mudah dipahami. Kalkulasi-kalkulasi harga secara online dan penawaran untuk kombinasi-kombinasi produk spesial ("Belilah dua produk dengan hanya Rp. 200.000,-") memfasilitasi keputusan pelanggan. Cara ini juga membantu ketika kombinasi-kombinasi produk tidak memungkinkan dan kurang baik diarahkan kepada pelanggan atau ketika perhatian mereka digambarkan kepada pelengkap yang masuk akal (cross-selling). Seringkali cara ini menjadi rekomendasi yang bermanfaat bagi pelanggan ketika membeli produk yang berkualitas tinggi dan mahal (up-selling).

Situasi ideal bisa terlihat seperti ini:

- $\quad$ Penawaran meliputi produk-produk dan layanan-layanan pelengkap.

- Jangkauan dilengkapi oleh layanan-layanan yang ditawarkan oleh pihak ketiga.

- Harga-harga dan persyaratan-persyaratan dari pemasok pihak ketiga yang terintegrasi dideskripsikan dengan cara yang mudah dipahami.

- Pelanggan-pelanggan bisa meletakkan bersama-sama produk mereka sendiri atau layanan menurut harapan mereka (konfigurasi).

- Konfigurasi-konfigurasi produk, daftar pengecekan, sistem-sistem perencanaan dan lainlain, membantu pemilihan produk-produk dan komponen-komponen. 


\section{USEF04 Sistem-sistem rekomendasi}

Pertanyaan: Seberapa baik sistem-sistem rekomendasi pada fungsi situs web?

\begin{tabular}{|c|c|} 
Pilihan Anda & Arti-arti yang mungkin \\
\hline+ & $\begin{array}{l}\text { Sistem-sistem rekomendasi sangat baik; kualitas dari rekomendasi- } \\
\text { rekomendasi meningkat menurut panjang dan intensitas dari hubungan } \\
\text { pelanggan }\end{array}$ \\
\hline+ & Sistem-sistem rekomendasi yang baik \\
- & Sistem-sistem rekomendasi ada \\
-- & Tidak ada sistem-sistem rekomendasi, meskipun diinginkan \\
n.r. & $\begin{array}{l}\text { Kriteria tidak diterapkan, tidak relevan (Sistem-sistem rekomendasi tidak bisa } \\
\text { dipertimbangkan) }\end{array}$
\end{tabular}

Deskripsi:

Rekomendasi-rekomendasi yang diotomatisasi bagi pelanggan-pelanggan dipicu dalam bentuk cross- and up-selling sama baiknya dengan collaborative filtering. Rekomendasi-rekomendasi cross- and up-selling diturunkan dari situasi pembelian yang umum dari pelanggan-pelanggan dan riwayat transaksi mereka. Dalam rangka memicu rekomendasi-rekomendasi bagi personalised cross-selling, informasi lebih jauh mengenai pelanggan, misalnya dari kecenderungan profil, profil sosio demografis atau profil interaksi perlu juga diperhitungkan.

Dengan collaborative filtering informasi pribadi dari pengguna-pengguna lain juga digunakan untuk membuat rekomendasi-rekomendasi. Pelanggan diperlihatkan dengan apa yang pelanggan lain lihat dengan kecenderungan sama yang telah dibeli. Basis ini juga merupakan informasi dari profil-profil pengguna, dalam hal mana profil-profil dari pengguna-pengguna lain juga memiliki pengaruh yang dapat dipertimbangkan pada rekomendasi.

Sementara evaluasi pribadi dari pengguna (kecenderungan profil) bisa dipertimbangkan sebagai statis secara relatif, analisis-analisis log file mengungkapkan informasi yang dinamis (profil interaksi). Kombinasi dari beberapa jenis profil mengarah secara umum kepada rekomendasirekomendasi terbaik, dalam hal mana kenaikan informasi yang dinamis memperbaiki kualitas rekomendasi-rekomendasi.

SItuasi ideal bisa terlihat seperti ini:

- Instrumen-instrumen cross- and up-selling menyerahkan proposal-proposal pelengkap kepada produk utama.

- Sistem-sistem collaborative filter menawarkan rekomendasi-rekomendasi produk surefire yang muncul kepada ekspektasi-ekspektasi pelanggan.

- Kualitas rekomendasi-rekomendasi meningkat dengan panjang dan intensitas dari hubungan pelanggan. 


\section{USEF05 Pemakaian Hypermedia}

Pertanyaan: Efek-efek apakah yang Anda dapatkan pada penggunaan hypermedia?

$\begin{array}{ll}\text { Pilihan Anda } & \text { Arti-arti yang mungkin } \\ ++ & \text { Penggunaan hypermedia sangat baik } \\ + & \text { Penggunaan hypermedia yang baik } \\ - & \text { Penggunaan hypermedia tidak memuaskan } \\ -- & \text { Penggunaan hypermedia tidak mencukupi } \\ \text { n.r. } & \text { Kriteria tidak diterapkan, tidak relevan }\end{array}$

Deskripsi:

Hypermedia muncul melalui kombinasi dari hypertext dan elemen-elemen multimedia. Kami berbicara multimedia ketika setidaknya dua media yang didukung komputer yang berbeda (teks, suara, animasi grafis, dan video) dikaitkan bersama-sama.

Presentasi-presentasi produk pada Internet secara efektif didukung oleh penggunaan situs-situs web multimedia (hypermedia). Sebagai sebuah contoh, urutan-urutan video memperlihatkan sebuah produk saat digunakan mampu secara efektif menggantikan teks dan foto-foto. Contoh yang lebih jauh adalah urutan-urutan audio yang memainkan penjelasan produk, interview dengan pengguna-pengguna atau cuplikan-cuplikan musik.

Situasi ideal bisa terlihat seperti ini:

- Kualitas: hypermedia yang digunakan secara teknis sangat baik dipersiapkan.

- Fungsionalitas: hypermedia yang digunakan menawarkan kepada pengguna sebuah keuntungan tambahan yang nyata.

- Kuantitas: Keragaman dari penggunaan hypermedia sesuai dengan kebutuhan-kebutuhan pengguna ("Media Richness" yang memadai). 


\title{
EOU04 Desain dari prosedur pemesanan
}

Pertanyaan: Apakah prosedur pemesanan sederhana dan jelas?

\author{
Pilihan Anda Arti yang mungkin \\ ++ $\quad$ Prosedur pemesanan sangat sederhana dan sangat jelas. \\ $+\quad$ Prosedur pemesanan sederhana dan jelas. \\ Prosedur pemesanan rumit dan tidak jelas. \\ -- $\quad$ Prosedur pemesanan sangat rumit dan benar-benar tidak jelas. \\ n.r. $\quad$ Kriteria tidak dapat diterapkan, tidak relevan
}

Deskripsi:

Prosedur pemesanan memerlukan beberapa tahap: dari memilih produk, menemukan harga dan memilih metode pembayaran untuk memutuskan bentuk distribusi yang diinginkan.

Situasi ideal bisa terlihat seperti ini:

- $\quad$ Setiap tahap dijelaskan kepada pelanggan dengan cara yang presisi dan dapat dipahami. Pelanggan-pelanggan berada di seluruh waktu yang jelas ketika mereka berada dalam prosedur dan konsekuensi dari tahap berikutnya. Kembali melanjutkan prosedur pemesanan atau membatalkannya adalah tidak sulit.

- "Accept Buttons" adalah selalu diposisikan sebagai data sesuai dengan kontraknya (misalnya persyaratan-persyaratan jual-beli, persyaratan pembayaran, harga dan lain-lain) bisa dilihat dan harus diaktivasi.

- $\quad$ Setelah prosedur pemesanan tingkat pertama dipersingkat ketika pelanggan tidak harus mendefinisikan metode pembayaran dan distribusi pada setiap pembelian yang baru (misalnya "One-Click-Ordering").

- Negosiasi harga - sebisa mungkin - dapat dijalankan dengan mudah dan dengan cara yang dimengerti. Hal ini juga berlaku bagi pemasok-pemasok dari layanan-layanan tambahannya, jika tersedia.

- Pemasok menawarkan beberapa cara yang berbeda terhadap pemesanan dari pelangganpelanggan yang memilih metode yang lebih mereka sukai (misalnya email order, onlineform, shopping basket). 


\section{USEF06 Model-model dan metode-metode penetapan harga}

Pertanyaan: Apakah model-model pengaturan harga diterapkan dan metode-metode harga yang tersedia mengarah kepada harga-harga individual dan adil?

\begin{tabular}{|c|c|} 
Pilihan Anda & Arti-arti yang mungkin \\
\hline++ & Harga cocok, individual dan adil, tergantung kepada profil pelanggan \\
\hline+ & Harga sesuai dipertimbangkan \\
\hline- & Harga tidak sesuai dipertimbangkan \\
\hline-- & Harga terlalu umum dan tidak adil \\
\hline n.r. & Criterion not applicable, not relevant \\
\hline
\end{tabular}

Deskripsi:

1. Metode-metode pemberian harga

Dalam Internet, beragam mekanisme penentuan harga diterapkan; rekomendasi-rekomendasi harga yang tetap dari pemasok, negosiasi individual antara pembeli dan penjual, lelang dari sisipenjualan (seorang penjual bernegosiasi dengan banyak pembeli, dengan penjual menentukan waktu dan minimal penawaran), lelang dari sisi-pembelian (Seorang pembeli menerima penawaran-penawaran dari sejumlah penjual-penjual), dan sistem-sistem pasar bursa. Mekanisme ini tidak semuanya cocok untuk setiap produk. Sudah menjadi tugas pemasok untuk memilih kesepakatan mekanisme harga yang cocok dan untuk menawarkan kepada pelanggannya.

Metode-metode penentuan harga penting untuk diperoleh. Dengan bantuan sistem-sistem agen intelijen, konsumen bisa mendapatkan informasi pada jaringan mengenai produk-produk dan harga dan menyetel perbandingan harga elektronik. Dengan tingkat kenaikan informasi ini konsumenkonsumen menjadi kurang siap untuk membeli pada harga yang berlebihan atau tidak adil.

2. Model-model pengaturan harga pelanggan individual

Tergantung kepada kebiasaan membeli mereka, pelanggan bisa ditawarkan harga-harga individual, berdasarkan kepada frekuensi pembelian mereka, pergantian atau isi dari keranjang belanja. Sistem-sistem diskon memungkinkan untuk memberikan hadiah kepada pengguna yang teratur dengan pengurangan-pengurangan harga khusus atau voucher.

Situasi ideal bisa terlihat seperti ini:

- Metode-metode penentuan harga yang ditawarkan adalah sesuai dengan transaksi dan hasilnya dengan harga yang adil.

- Model pengesetan harga adalah sesuai kepada transaksi. Jika, misalnya, pelanggan membutuhkan sebuah buku dengan segera, mereka tidak akan dipersiapkan untuk menunggu selama tiga minggu sampai harga ditetapkan melalui lelang. Disini pelanggan mengharapkan harga tetap yang kompetitif tersedia saat itu juga.

- Pelanggan-pelanggan reguler yang mendapatkan keuntungan dari reduksi-reduksi harga individual, berdasarkan kepada profil pelanggan. 


\section{EOU05 Integrasi dari layanan-layanan umum}

Pertanyaan: Apakah mudah memilih layanan-layanan umum?

\begin{tabular}{|c|c|}
\hline Plihan Anda & Arti yang mungkin \\
\hline++ & $\begin{array}{l}\text { Layanan-layanan umum terintegrasi dengan baik dan bisa dengan sangat } \\
\text { mudah dipilih. }\end{array}$ \\
\hline+ & Layanan-layanan umum diintegrasikan dan bisa dipilih dengan mudah. \\
\hline- & Layanan-layanan umum hanya bisa dipilih dengan kesulitan. \\
\hline-- & Layanan-layanan tidak terintegrasi, meskipun diinginkan. \\
\hline n.r. & $\begin{array}{l}\text { Kriteria tidak dapat diterapkan, tidak relevan (Layanan-layanan umum tidak } \\
\text { masuk akal) }\end{array}$ \\
\hline
\end{tabular}

Deskripsi:

Layanan-layanan umum adalah modul-modul perangkat lunak yang mendukung sebuah prosedurprosedur transaksi elektronika. Dalam e-commerce melibatkan layanan-layanan khusus bagi prosedur pembayaran dan logistik-logistik. Layanan-layanan umum didasarkan kepada standarstandar, yang memfasilitasi integrasi mereka kedalam beragam platform. Sebuah pilihan sederhana dari layanan-layanan berarti bahwa mereka terintegrasi secara baik kedalam prosedur-prosedur dan bahwa pembeli bisa memilih antara beberapa layanan.

Situasi ideal bisa dilihat seperti ini:

- Pelanggan-pelanggan bisa membayar lebih mudah dan bisa memilih cara-cara pembayaran yang disukai: kartu kredit (Visa, Mastercard, dan lain-lain), bill with payingin slip, check, payment collect/COD, dan payment by mobile.

- Pilihan sederhana dan individual dari rekanan distribusi yang disukai (Post, UPS, FedEx, dan lain-lain.) dan tanggal pengirimannya.

- Seluruh persyaratan menghasilkan pilihan kanal-kanal distribusi, tanggal pengiriman, dan cara pembayaran terdokumentasi secara komprehensif. 


\section{USEF07 Integrasi dari aplikasi-aplikasi e-commerce}

Pertanyaan: Dapatkah aplikasi-aplikasi e-commerce diintegrasikan kedalam sistem-sistem pelanggan?

\section{Pilihan Anda Arti-arti yang mungkin}

$++$

$+$

$-$

$--$

n.r.
Kesempatan yang sangat baik untuk mengintegrasikan kedalam sistem-sistem informasi pelanggan

Kesempatan yang baik untuk mengintegrasikan kedalam sistem-sistem informasi pelanggan

Kesempatan yang tidak mencukupi untuk mengintegrasikan kedalam sistemsistem informasi pelanggan

Tidak ada kesempatan untuk mengintegrasikan kedalam sistem-sistem informasi pelanggan, meskipun diinginkan

Kriteria tidak dapat diterapkan, tidak relevan (Integrasi tidak akan dipertimbangkan.)

\section{Deskripsi:}

Salah satu dari keuntungan-keuntungan utama Internet dilahirkan dari produktivitas yang tinggi dari prosedur-prosedur transaksi. Seberapa besar efisiensi sebuah transaksi bisa disetel tergantung kepada besarnya lingkup dari mengkoordinasikan sistem-sistem dari pemasok dan pembeli. Integrasi dari Internet menawwarkan kedalam sistem Enterprise Resource Planning (ERP) pelanggan, misalnya, bisa membuat keseluruhan proses transaksi dari sisi pelanggan lebih mudah, kepada penempatan pemesanan, melalui tanda terima barang-barang yang dibeli kepada pengecekan dan penyelesaian dari faktur (tagihan).

Situasi ideal terlihat seperti ini:

- Data penagihan dan pemesanan ditransmisikan secara elektronik atau tersedia untuk diunduh.

- B2C: informasi tentang logistik-logistik (catatan pengiriman, jenis, dan tanggal) dan pembayaran (tagihan-tagihan (faktur), rata-rata pembayaran, dan statistik-statistik) ditransmisikan dalam bentuk elektronik dan memasuki kepada aplikasi-aplikasi lokal pelanggan (misalnya MS Office, MS Money) in dalam bentuk tanda terima elektronik.

- $\quad$ B2B: aplikasi e-commerce penjual dapat berguna diintegrasikan kedalam sistem ERP pelanggan. 


\section{USEF08 Perutean dan penelusuran}

Pertanyaan: Bisakah order ditelusuri seluruhnya?

\begin{tabular}{cl} 
Pilihan Anda & Arti-arti yang mungkin \\
\hline++ & Layanan-layanan perutean dan penelusuran sangat baik \\
\hline+ & Layanan-layanan perutean dan penelusuran baik \\
\hline- & Layanan-layanan perutean dan penelusuran tidak memuaskan \\
\hline- & Tidak ada layanan-layanan perutean dan penelusuran, meskipun diinginkan \\
n.r. & $\begin{array}{l}\text { Kriteria tidak dapat diterapkan, tidak relevan (Layanan-layanan perutean dan } \\
\text { penelusuran tidak akan dipertimbangkan.) }\end{array}$
\end{tabular}

Deskripsi:

Konsep "tracking (perutean)" berarti setiap tingkat dari pemesanan, antara penempatan pemesanan dan pengiriman barang-barang kepada penerima. Dengan "tracing (penelusuran) kita artikan sebagai kebalikan dari order setelah tanda terima barang. Secara umum, merupakan keuntungan yang besar kepada pemasok dan pelanggan sama jika perutean dan penelusuran ditawarkan. Hal ini memungkinkan pelanggan untuk menanyakan informasi mengenai samapi tingkat mana pemesanan telah dicapai dan status pengiriman barang-barangnya sendiri. Ini memberikan fasilitas perencanaan pelanggan dan menghemat pembeli dan penjual pada kebutuhan konsumsi waktu.

Situasi ideal bisa terlihat seperti ini:

- $\quad$ Perutean dan penelusuran tersedia online.

- Data pemesanan pribadi mudah diakses, handal dan mudah dipahami. 


\section{EOU06 Akses kepada dukungan pelanggan}

Pertanyaan: Seberapa mudah akses kepada dukungan pelanggan?

\begin{tabular}{|c|c|}
\hline Pilihan Anda & Arti yang mungkin \\
\hline++ & Sangat mudah untuk mengakses dukungan pelanggan \\
\hline+ & Mudah untuk mengakses dukungan pelanggan \\
\hline- & Sulit untuk mengakses dukungan pelanggan \\
\hline-- & Tidak ada akses ke dukungan pelanggan, meskipun diinginkan \\
\hline n.r. & $\begin{array}{l}\text { Kriteria tidak dapat diterapkan, tidak relevan (Akses ke dukungan pelanggan } \\
\text { menjadi tidak penting.) }\end{array}$ \\
\hline
\end{tabular}

Deskripsi:

Kriteria ini mengukur "ease of use" dari dukungan pelanggan pada sebuah situs web. Ini berarti mengevaluasi apakah informasi mengenai kemampuan akses dari dukungan pelanggan (contact data, opening times) tersedia dan apakah dapat diakses melalui beragam kanal-kanal (email, telephone, letter). Hal ini tepatnya ketika masalah-masalah muncul bahwa pelanggan e-commerce juga perlu untuk bisa menentukan arah, kontak fisik dengan perwakilan perusahaan. Bagaimanapun juga, hal ini sering terlupakan.

Kualitas dari dukungan pelanggan diukur dengan kriteria "Kinerja dukungan pelanggan” (USEF09).

Situasi ideal dapat terlihat seperti ini:

- $\quad$ Dukungan pelanggan bisa mengakses dengan mudah pada situs web.

- Dukungan pelanggan tersedia sepanjang waktu.

- Dukungan pelanggan bisa diakses melalui email, telepon dan surat/faks.

- Dukungan pelanggan menggunakan media yang sama, misalnya email dijawab dengan email, pemanggilan telepon dijawab juga dengan telepon, dan seterusnya. 


\section{USEF09 Kinerja dukungan pelanggan}

Pertanyaan: Seberapa puaskah Anda dengan kualitas dukungan pelanggan?

\begin{tabular}{|c|c|}
\hline Pilihan Anda & Arti-arti yang mungkin \\
\hline++ & Dukungan pelanggan yang sangat membantu \\
\hline+ & Dukungan pelanggan yang membantu \\
\hline- & Dukungan pelanggan yang kurang membantu \\
\hline-- & Tidak ada dukungan pelanggan \\
\hline n.r. & $\begin{array}{l}\text { Kriteria tidak dapat diterapkan, tidak relevan (dukungan pelanggan tidak } \\
\text { perlu dipertimbangkan) }\end{array}$ \\
\hline
\end{tabular}

Deskripsi:

Kriteria ini mengukur usefulness dari dukungan pelanggan pada situs web. Pekerjaan dari dukungan pelanggan (customer support) membantu pelanggan dengan pertanyaan-pertanyaan dan masalah-masalah yang muncul setelah pembelian sebuah produk. Pengaturan prosedur-prosedur pengembalian, keluhan-keluhan, dan jika perlu, perbaikan barang semuanya merupakan bagian dari dukungan pelanggan.

Pengalaman memperlihatkan bahwa konsumen-konsumen online mengatur toko yang lebih besar oleh kepedulian dan nasehat dari pelanggan yang baik. Dukungan pelanggan oleh sebab itu memainkan aturan-aturan penting bagi sebuah keputusan pembelian. Dari sudut pandang pemasok, dukungan pelanggan berkontribusi ke arah "educating" pelanggan. Informasi tambahan (dalam bentuk buku pegangan online, bantuan koreksi kesalahan, pustaka-pustaka online, perangkat lunak yang bisa diunduh, dan lain-lain) mengenai produk-produk dan layanan-layanan meningkatkan kemampuan-kemampuan pelanggan dam oleh karena itu berkontribusi kepada kesetiaan pelanggan.Sebuah perubahan pemasok akan melibatkan pelanggan dalam menginvestasikan lebih banyak waktu dan energi dalam membagun kemampuan-kemampuan mereka. Oleh karena itu mengapa kualitas dukungan pelanggan memiliki peningkatan pengaruh pada hubungan pelanggan dan kesetiaan.

Akses kepada dukungan pelanggan dievaluasi oleh kriteria "Access to customer support (Akses kepada dukungan pelanggan) (EOU06)”

Situasi ideal bisa terlihat seperti ini:

- Dukungan pelanggan bereaksi secara cepat dan handal kepada pertanyaan-pertanyaan pelanggan.

- Pelanggan menerima seluruh informasi yang mereka butuhkan untuk menggunakan produk yang diperoleh.

- Sebuah hubungan individual muncul antara pembeli dan dukungan pelanggan. Pelanggan memiliki kesan atau rasa bahwa pertanyaan-pertanyaan mereka sedang ditangani secara pribadi.

- Pelanggan menerima informasi yang tidak diminta (Tetapi selama diinginkan) mengenai produk-produk dan informasi yang diperbaharui (misalnya dalam bentuk suratkabar yang dipersonalisasi). 


\section{EOU07 Akses kepada komunitas virtual}

Pertanyaan: Apakah ada akses kepada komunitas virtual dan apakah mudah menemukannya?

\begin{tabular}{cl} 
Pilihan Anda & Arti yang mungkin \\
\hline++ & Akses yang sangat mudah dan cepat ke komunitas virtual \\
\hline+ & Kemudahan akses ke komunitas virtual \\
\hline- & Sulit untuk mengakses ke komunitas virtual \\
-- & Tidak ada akses ke komunitas virtual, meskipun diinginkan \\
n.r. & $\begin{array}{l}\text { Kriteria tidak dapat diterapkan, tidak relevan (Komunitas virtual tidak bisa } \\
\text { dipertimbangkan) }\end{array}$
\end{tabular}

Deskripsi:

"A Community is a group of like-minded people who band together for frequent interaction because it is mutually beneficial and provides a sense of safety and a sense of identity."

Daniel Janal (2000)*)

Dalam hubungan-hubungan sosial komunitas virtual, mengembangkan melalui media elektronika tanpa peduli waktu dan tempat adalah berada di garis depan. Komunitas virtual bisa dikembangkan sebagai platform yang terpisah dari pemasok-pemasok, atau mereka terikat secara dekat dengan situs web komersial. Pelanggan seharusnya ditawarkan akses termudah yang paling mungkin ke komunitas. Permasalahan-permasalahan yang muncul pada komunitas seharusnya memiliki relasi atau hubungan langsung kepada penawaran-penawaran e-commerce (Misalnya tema "memasak" dikaitkan ke toko-toko makanan)

Situasi ideal bisa terlihat seperti ini:

- Akses ke komunitas virtual yang relevan ditawarkan.

- Komunitas yang relevan terintegrasi secara langsung dengan penawaran dan maka mudah untuk ditemukan.

*) Janal, Daniel S. (2000): Dan Janal's Guide to Marketing on the Internet - Getting People to Visit, Buy, and Become Customers for Life. New York, Chichester: Wiley, 2000. 


\section{USEF10 Memperoleh keuntungan dari relasi-relasi di dalam komunitas}

Pertanyaan: Bagaimana Anda mengevaluasi kualitas dan kuantitas dari relasi-relasi di dalam komunitas virtual?

\begin{tabular}{|ll} 
Pilihan Anda & Arti-arti yang mungkin \\
\hline++ & Relasi-relasi yang sangat baik \\
\hline+ & Relasi-relasi yang baik \\
\hline- & Relasi-relasi yang kurang baik \\
-- & Relasi-relasi yang sangat buruk \\
\hline n.r. & Kriteria tidak dapat diterapkan, tidak relevan
\end{tabular}

Deskripsi:

Sementara terdapat komunitas-komunitas virtual di dalam Internet ketika mendapatkan waktu luang dan hubungan pribadi selama bertahun-tahun, peningkatan keuntungan dari WWW untuk tujuan komersial telah mengarah kepada munculnya apa yang disebut dengan komunitas transaksi atau bisnis. Komunitas ini menempatkan penekanan mereka kepada bantuan dalam memilih dan mengakuisisi produk-produk dan layanan-layanan.

Keuntungan komunitas bagi anggota-anggotanya bergantung kepada kualitas dan kuantitas relasirelasi ini. Semakin banyak pelanggan yang secara aktif berpartisipasi di dalam forum, semakin besar pula keuntungan individual-individual dari pengetahuan dan pengalaman yang diakumulasikan bersama yang lain. Ketika mengevaluasi kualitas dari relasi-relasi faktor utamanya adalah apakah komunitas dipertimbangkan dapat dipercaya dan anggota-anggotanya memilik kompetensi. Model-model dari komunitas yang bisa dijadikan contoh dikenal dari bidang pemrograman perangkat lunak, dalam bentuk kelompok-kelompok dukungan bagi programmerprogrammer yang saling membantu satu sama lain dengan masalah-masalah pemrograman mereka. Dalam serangkaian waktu, anggota-anggota saling berbagi pengetahuan satu sama lain dan mengidentifikasi anggota yang lain dari siapa mereka secara teratur menerima informasi. Kepercayaan kepada sebuah komunitas meningkat dengan berjalannya waktu.

Di samping komunitas-komunitas yang berorientasi kepada tugas terdapat juga komunitas terbuka sehingga seseorang bisa mendapatkan keuntungan. Contoh terbaik adalah situs web Amazon.com, yaitu pembaca bisa meninggalkan pendapat mereka dari sebuah buku. Lebih dulu, pelanggan Amazon mengembangkan sebuah perasaan apakah sebuah komentar dari pembaca tertentu bisa diandalkan atau tidak.

Situasi ideal dapat terlihat seperti ini:

- $\quad$ Terdapat jumlah yang cukup dari anggota-anggota yang terdaftar di dalam komunitas.

- Sebuah jaringan dari relasi-relasi yang dapat dipercaya ada di dalam sebuah komunitas.

- Relasi-relasi menawarkan bantuan-bantuan yang bernilai dengan pertanyaan-pertanyaan dan masalah-masalah. 
- Komunitas menawarkan kesempatan untuk menghubungi ahli-ahli dan pribadi-pribadi lainnya yang sangat sulit untuk bisa dijangkau.

- Anggota-anggota komunitas saling menghargai satu sama lain dan mempunyai rasa memiliki dan rasa aman.

- Aturan-aturan tingkah laku di dalam komunitas harus jelas diletakkan dan dipatuhi baik oleh penyelenggara komunitas atau oleh organisasi yang dimiliki oleh pengguna (netiquette). 


\section{USEF11 Memperoleh keuntungan dari ketersediaan isi di dalam komunitas}

Pertanyaan: Bagaimana Anda mengevaluasi ketersediaan isi di dalam komunitas virtual?

$$
\begin{array}{|c|c|}
\text { Pilihan Anda } & \text { Arti-arti yang mungkin } \\
\hline++ & \text { Ketersediaan isi yang sangat baik di dalam komunitas } \\
\hline+ & \text { Ketersediaan isi yang baik di dalam komunitas } \\
\hline- & \text { Ketersediaan isi yang kurang baik di dalam komunitas } \\
\hline-- & \text { Ketersediaan isi yang sangat buruk di dalam komunitas } \\
\hline \text { n.r. } & \text { Kriteria tidak dapat diterapkan, tidak relevan }
\end{array}
$$

Deskripsi:

Selain kepercayaan di dalam komunitas dan kualitas dari relasi-relasi (Kriteria "Profiting from relations"), isi di atas semuanya merupakan faktor yang menentukan apakah pengguna Internet memakai fungsi-fungsi yang ditawarkan oleh komunitas atau tidak.

Dengan cara ini komunitas melayani di satu sisi sebagai sumber informasi di sisi lain sebagai sebuah penyaring informasi. Khususnya kemudian, penyaringan informasi dan presentasi pribadi bagi sebuah pelanggan individu adalah menjadi lebih penting dengan peningkatan melimpahnya informasi di dalam Internet.

Situasi ideal bisa terlihat seperti ini:

- Fokus utama dari komunitas merefleksikan kepentingan dari kelompok pembeli yang relevan (kelompok target).

- Komunitas adalah sebuah repositori dari pengetahuan yang dispesialisasikan ketika seorang anggota hanya bisa memperolehnya di dalam komunitas.

- Selain isi yang dipublikasikan secara resmi, anggota-anggota komunitas menghasilkan kontribusi-kontribusi yang bernilai bagi mereka sendiri.

- Komunitas menawarkan informasi yang benar dan komprehensif dari sebuah lingkup yang luas dari sumber-sumber yang berbeda (termasuk kompetitor pemasok).

- Sebuah pertukaran informasi yang tepat mengambil tempat antara anggota-anggotanya (tidak ada informasi yang berlebihan maupun membosankan). 


\section{USEF12 Pemberdayaan pelanggan yang dihasilkan oleh komunitas}

Pertanyaan: Apakah komunitas menghasilkan pemberdayaan pelanggan dan keuntungan bagi pelanggan?

\begin{tabular}{cl} 
Pilihan Anda & Arti-arti yang mungkin \\
++ & Komunitas virtual menghasilkan pemberdayaan pelanggan yang kuat \\
\hline+ & Komunitas virtual menghasilkan pemberdayaan pelanggan \\
- & Komunitas virtual tidak menghasilkan pemberdayaan pelanggan \\
-- & Komunitas virtual mengarah kepada harga yang lebih mahal \\
n.r. & Kriteria tidak dapat diterapkan, tidak relevan
\end{tabular}

Deskripsi:

Di dalam komunitas virtual sejumlah besar pelanggan terikat bersama-sama. Pelanggan-pelanggan bersama-sama berada pada posisi untuk memanfaatkan pengaruh yang bisa dipertimbangkan pada pemasok, yang dikenal sebagai "customer empowerment", atau "the customer has a vote". Ini menganugerahkan manfaat-manfaat tambahan pada anggota-anggota komunitas, khususnya ketika kemudian diteruskannya pemenuhan permintaan, mempercepat pengembangan produk, atau mendapatkan harga yang rendah dan kinerja meningkat.

Komunitas juga membantu secara tidak langsung dalam meningkatkan pemberdayaan; ketersediaan informasi mengenai harga sesuai juga dengan kinerja beragam pemasok yang mengurangi informasi dari satu sisi dan meningkatkan transparansi pasar. Ini memungkinkan pelanggan untuk mengalokasikan harga terendah dan pemasok yang paling handal dengan usaha yang relatif kecil. Misalnya: www.priceline.com, www.teures-billiger.de, preissuchmaschine.de.

Sebagai hasil dari jatuhnya biaya-biaya informasi sekarang dan kemudian disebut dengan munculnya "reverse markets". Pelanggan-pelanggan di dalam pasar ini merumuskan kebutuhankebutuhan individual mereka atas produk-produk dan layanan-layanan dan dengan demikian mengatur proses-proses produksi dan transaksi yang utama. Penjual-penjual dan produsenprodusen kemudian mempunyai tugas melengkapi kebutuhan-kebutuhan pelanggan kepada kepuasan yang diinginkan oleh mereka.

Situasi ideal bisa terlihat seperti ini:

- Komunitas mengerjakan tugas dari perlindungan konsumen dan bertindak sebagai perantara antara konsumen dan pemasok.

- Komunitas mengarah kepada transparansi pasar yang lebih besar dan memperlihatkan rip-off dan penipu-penipu.

- Komunitas yang membeli menerima kuatitas diskon. Misalnya: www.wechselstube.ch 


\section{EOU08 Ketersediaan sistem}

Pertanyaan: Apakah ketersediaan situs web tidak dapat diinterupsi selama 24 jam?

\begin{tabular}{cl} 
Pilihan Anda & Arti yang mungkin \\
\hline++ & Situs web tersedia secara permanen \\
\hline+ & Halaman-halaman tertentu kadang-kadang tidak tersedia \\
\hline- & Halaman-halaman tertentu sering tidak tersedia \\
-- & Keseluruhan situs web sering tidak tersedia \\
n.r. & Kriteria tidak tersedia, tidak relevan
\end{tabular}

Deskripsi:

Kesempatan untuk membeli selama bergeraknya jarum jam adalah sebuah penawaran yang menarik dan salah satu keunggulan-keunggulan esensial dibandingkan dengan sebuah toko brickand-mortar. Sebuah prasyarat bagi ketersediaan secara permanen sebuah toko adalah sebuah infrastruktur teknis yang bisa diandalkan.

Situasi ideal bisa terlihat seperti ini:

- Informasi produk dan pemesanan bisa ditelepon kapanpun.

- $\quad$ Pesanan-pesanan bisa ditempatkan selama 24 jam sehari 7 hari seminggu. 


\section{EOU09 Desain antarmuka pengguna}

Pertanyaan: Bagaimana Anda mengevaluasi desain antarmuka pengguna?

\begin{tabular}{|cl} 
Pilihan Anda & Arti yang mungkin \\
\hline++ & Antarmuka pengguna yang sangat bagus \\
\hline+ & Antarmuka pengguna bagus \\
\hline- & Antarmuka pengguna buruk \\
\hline-- & Antarmuka pengguna sangat buruk \\
\hline n.r. & Kriteria tidak dapat diterapkan, tidak relevan
\end{tabular}

Deskripsi:

Antarmuka pengguna adalah lebih baik dideskripsikan sebagai "point of contact” antara orang dan aplikasi e-commerce. Antarmuka pengguna merepresentasikan informasi digital ke pelanggan dalam bentuk yang mereka bisa mengerti. Sebuah desain yang distandarisasi dan konsisten meningkatkan pemanggilan kembali nilai. Juga secara umum merupakan keunggulan jika desain mencerminkan materi iklan yang ada. Karena posisi utamanya dalam hubungan dengan pelanggan, antarmuka pengguna adalah sangat penting.

Berharga untuk dicatat bahwa meningkatnya tingkat penggunaan Internet di masa depan yang bisa diketahui sebelumnya terutama akan menjadi pengguna-pengguna yang memiliki hanya sedikit pengetahuan teknis. Dengan demikian perlu untuk memperbaiki ease of use pada situs-situs Internet, sejak itu pengguna-pengguna ingin menavigasikan melalui halaman-halaman dengan cara yang paling sederhana.

Penawaran-penawaran e-commerce bisa dipanggil dimanapun di dunia. Sebuah antarmuka pengguna yang baik juga meningkat melalui sebuah pilihan bahasa yang disesuaikan ke sebuah kelompok target. Teks-teks memperhitungkan kondisi-kondisi kultural dan lokal dengan benar (tata bahasa, sintaks, dan isi)

Situasi ideal bisa terlihat seperti ini:

- Antarmuka mudah digunakan.

- Desain distandarisasi dan konsisten.

- Navigasi mudah dan intuitif.

- Desain cocok untuk kebutuhan-kebutuhan dari pengunjung yang pertama kali datang dan menginspirasikan pengguna untuk mengklik lebih jauh kedalam situs web.

- Fungsi-fungsi bantuan (Help) tersedia secara permanen dan mudah digunakan.

- Komponen-komponen antarmuka tidak memicu masalah-masalah kompatibilitas apapun bagi pengguna.

- Aspek-aspek global dimasukkan sebagai pertimbangan. 


\section{USEF13 Meningkatkan produktivitas dengan menghemat waktu}

Pertanyaan: Dapatkah Anda menghemat waktu dengan menggunakan situs web?

\begin{tabular}{|c|c|} 
Pilihan Anda & Arti-arti yang mungkin \\
\hline++ & Penghematan waktu yang sangat besar \\
\hline+ & Sedikit menghemat waktu \\
\hline- & Tidak ada waktu yang dihemat \\
\hline-- & Kehilangan waktu \\
\hline n.r. & Kriteria tidak dapat diterapkan, tidak relevan \\
\hline
\end{tabular}

Deskripsi:

Mengunjungi sebuah situs web bisa memberikan keuntungan kepada pelanggan-pelanggan dengan menghemat waktu mereka. Memenangkan waktu berarti tidak harus pergi ke sebuah toko "bricksand-mortar" atau menempatkan pemesanan melalui telepon. Bagaimanapun juga, menghemat waktu seharusnya tidak dibatalkan oleh kerumitan, juga interaksi yang lambat dengan situs web.

Oleh karena itu kriteria ini mengukur seberapa cepat seorang pelanggan berhasil mengatur sebuah transaksi. Sebuah contoh yang bagus dari penghematan waktu adalah Amazon's 1-Click shopping, Anda hanya membutuhkan beberapa klik untuk membeli sebuah buku. Di hampir semua kasus sebuah prasyarat untuk menghemat waktu adalah pemasok memiliki profil pelanggan. Sehingga waktu yang dihemat hanya bisa dievaluasi secara layak dari pelanggan-pelanggan reguler.

Penghematan waktu juga dipengaruhi oleh waktu respons dan pemuatan sebuah situs web. Situs web yang dirancang secara teliti dengan waktu pemuatan yang lama adalah merupakan sebuah kerugian. Ini membutuhkan perancang web untuk mempertimbangkan keunggulan-keunggulan dan latar belakangnya dengan sangat hati-hati (misalnya ukuran dan jumlah gambar atau animasi yang diterapkan).

Akhirnya, penghematan waktu bisa juga dihasilkan dari kecepatan pengiriman. Pemesanan secara langsung dari distributor, yang memiliki stok produk adalah seringkali lebih cepat daripada pemesanan dari toko tradisional, yang kemudian juga harus menempatkan sebuah pemesanan secara grosir.

Situasi ideal bisa terlihat seperti ini:

- Bandingkan dengan pembelian secara tradisional (toko, telepon), dan juga bandingkan dengan situs-situs web yang lain, situs web memungkinkan pelanggan untuk menghemat waktu mereka dalam seluruh fase transaksi.

- Waktu respons dan pemuatan dari situs web adalah cepat atau setidaknya dapat diterima. 


\section{USEF14 Interaksi}

Pertanyaan: Bagaimana Anda menyebut sebuah situs web ”interaktif”?

\begin{tabular}{|c|c|}
\hline Pilihan Anda & Arti-arti yang mungkin \\
\hline++ & Interaksi yang sangat baik \\
\hline+ & Interaksi yang baik \\
\hline- & Interaksi yang terlalu banyak atau terlalu sedikit \\
\hline-- & Interaksi yang jauh terlalu banyak dan jauh terlalu sedikit \\
\hline n.r. & Kriteria tidak dapat diterapkan, tidak relevan \\
\hline
\end{tabular}

Deskripsi:

Satu keunggulan yang paling penting dari Internet dibandingkan dengan media lain adalah kealamiahan interaktifnya. Pada Internet setiap bisnis berada pada kontak langsung dengan pelanggan-pelanggannya. Kealamiahan interaktif bisa bereaksi kepada kebutuhan-kebutuhan pelanggan dan mengangkat relasi pelanggan. Interaksi memberikan pelanggan kesempatan untuk mempengaruhi setiap tingkat dari proses transaksi.

Situasi ideal bisa terlihat seperti ini:

- Situs web dirancang untuk berinteraksi. Pelanggan dapat memilih dari beragam pilihanpilihan prosedur tergantung kepada kebutuhan-kebutuhan mereka.

- Bagi produk-produk yang membutuhkan sebuah nasehat dari seorang konsultan tersedia online chatroom atau konfigurator online yang membantu meletakkan sebuah produk yang rumit bersama-sama secara interaktif (misalnya melengkapi sebuah mobil untuk memesan). 


\section{USEF15 Fungsi-fungsi personalisasi}

Pertanyaan: Dapatkan situs web cocok dengan kebutuhan-kebutuhan individual Anda atau operator menawarkan Anda informasi yang dibuat sesuai untuk Anda?

\begin{tabular}{cl} 
Pilihan Anda & Arti-arti yang mungkin \\
\hline++ & Fungsi-fungsi personalisasi yang sangat baik \\
\hline+ & Fungsi-fungsi personalisasi yang baik \\
\hline- & Fungsi-fungsi personalisasi yang kurang baik \\
\hline- & Tidak ada fungsi-fungsi personalisasi, meskipun diinginkan \\
n.r. & $\begin{array}{l}\text { Kriteria tidak dapat diterapkan, tidak relevan (Personalisasi tidak } \\
\text { diperhitungkan.) }\end{array}$
\end{tabular}

Deskripsi:

Aplikasi-aplikasi e-commerce dengan fungsi-fungsi personalisasi menyediakan informasi pada layar yang dibuat sesuai kepada kebutuhan-kebutuhan spesifik dari kelompok-kelompok pengguna atau pengguna tunggal (pelanggan). Personalisasi berdasarkan kepada informasi yang diminta dari pelanggan atau menarik kesimpulan dari tingkat laku mereka dan disimpan di dalam profil pelanggan atau pengguna. *) Dengan menggunakan informasi yang secara spesifik dimaksudkan kepada pelanggan-pelanggan, fungsi-fungsi personalisasi mengembangkan dialog pribadi dengan mereka, dengan demikian mengikat mereka lebih dekat kepada pemasok.

Banyak pengguna-pengguna saat ini mengambil fungsi-fungsi personalisasi begitu saja; pelanggan-pelanggan dialamati secara pribadi setelah mengulangi kunjungan ke sebuah situs web dan tidak harus memiliki kunci dalam detail alamat dan bank mereka setiap pembelian yang baru. Mereka dapat memilih informasi mana yang mereka inginkan pada sebuah situs web. Di samping trik-trik personalisasi yang sederhana ini, konsepnya mencakup sebuah kemungkinankemungkinan yang kaya, misalnya diferensiasi spesifik pelanggan dari kualitas dan harga, iklan yang bisa disesuaikan, laporan berkala individual, personalised cross-selling dan collaborative filtering (lihat kriteria "sistem-sistem rekomendasi”).

Manfaat-manfaat kepada pelanggan muncul secara prinsip dari pilihan spesifik dan adaptasi informasi. Dengan cara ini, pelanggan-pelanggan memiliki akses yang lebih cepat kepada informasi yang lebih baik. Dalam fase kesepakatan (agreement phase), proses pemesanan bisa diselesaikan jauh lebih cepat jika kecenderungan pribadi pelanggan-pelanggan dan data mengenai metode-metode harga, pembayaran, dan pengiriman telah direkam.

Situasi ideal bisa terlihat seperti ini:

- $\quad$ Pelanggan bisa memasuki situs web secara pribadi.

- Isi pada situs web bisa secara terpisah dipilih dan ditata oleh pelanggan.

- Ketika mereka mengunjungi ulang situs web, pelanggan tidak harus memiliki kunci lagi secara detail (seperti alamat, informasi pembayaran, kecenderungan dan lain-lain) mereka sudah diberikan.

- Pelanggan-pelanggan bisa memiliki akses kepada order-order mereka sebelumnya (ordering history).

- Pelanggan-pelanggan menerima rekomendasi mengenai produk-produk dan asesorisasesoris berdasarkan kepada pembelian-pembelian atau kecenderungan-kecenderungan 
mereka sebelumnya.

- Seluruhnya berada pada fungsi-fungsi personalisasi yang bekerja dengan baik sehingga fungsi-fungsi tersebut mempercepat pengambilan keputusan dan prosedur-prosedur pemesanan.

*) Jenis-jenis profil pelanggan yang didaftarkan seperti berikut ini:

\begin{tabular}{|c|c|}
\hline Profile & Content \\
\hline \multicolumn{2}{|l|}{ Explicit profiles } \\
\hline $\begin{array}{l}\text { Identification } \\
\text { Profile }\end{array}$ & $\begin{array}{l}\text { user name, role, contact information, personal browser settings, address, } \\
\text { payment informati on, IP-address, etc. }\end{array}$ \\
\hline $\begin{array}{l}\text { Preference } \\
\text { Profile }\end{array}$ & self-revealed preferences (product meta data) \\
\hline $\begin{array}{l}\text { Socio-economic } \\
\text { Profile } \\
\text { Ratings }\end{array}$ & $\begin{array}{l}\text { self-categorization in predefined classes (age, gender, hobbies, etc.) } \\
\text { three types of ratings: of products, of reviews, of pages [scale e.g.: I } \\
\text { like it - not for me] }\end{array}$ \\
\hline Relationships & Relationships to other users/customers [e.g. "soul si sters"] \\
\hline Reviews/Opinions & Plain text, images, videos and other material \\
\hline \multicolumn{2}{|l|}{ Implicit profiles } \\
\hline \begin{tabular}{|l|} 
Transaction \\
Profile
\end{tabular} & $\begin{array}{l}\text { trans action log, product purchases linked to product meta data } \\
\text { (purchases, inquiries, payment, etc.) }\end{array}$ \\
\hline $\begin{array}{l}\text { Interaction } \\
\text { Profile }\end{array}$ & $\begin{array}{l}\text { click stream (pages viewed are linked to product meta data } \\
\text { [preference categories]) }\end{array}$ \\
\hline External data & $\begin{array}{l}\text { Inform ation procured from other sources [e.g. weather report, local } \\
\text { news, events, credit rating] }\end{array}$ \\
\hline
\end{tabular}




\section{TRUST01 Kepercayaan dari rekan bisnis (pemasok)}

Pertanyaan: Apakah rekan bisnis (pemasok) menginspirasikan keyakinan di dalam diri Anda?

\begin{tabular}{cl} 
Pilihan Anda & Arti yang mungkin \\
\hline++ & Rekan bisnis (pemasok) menginspirasikan keyakinan yang besar. \\
\hline+ & Rekan bisnis (pemasok) menginspirasikan keyakinan. \\
- & Rekan bisnis (pemasok) menginspirasikan sedikit keyakinan. \\
-- & Rekan bisnis (pemasok) tidak menginspirasikan keyakinan sama sekali. \\
n.r. & Kriteria tidak dapat diterapkan, tidak relevan.
\end{tabular}

Deskripsi:

Kepercayaan ditempatkan oleh seorang pelanggan kepada pemasok adalah sebuah elemen pokok dalam setiap kontrak pembelian. Dengan prosedur pembelian di dalam pasar elektronik pelangganpelanggan harus sudah merasakan keyakinan pada fase informasi, sehingga mereka siap untuk memberikan detail-detail pribadi dan melengkapi pembelian. Juga pada tingkatan yang lebih jauh dari transaksi cocok untuk memperkuat keyakinan pelanggan. Jangan after-sales phase dilupakan. Layanan after-sales phase memainkan peran penting dalam menentukan pelanggan menjadi seorang pelanggan yang setia.

Situasi ideal bisa dilihat seperti berikut ini:

- Perusahaan dideskripsikan dengan baik pada situs web (misalnya di bawah “about us”).

- Manajer dan staf yang langsung terlibat dengan pelanggan memperkenalkan diri mereka pada situs web dengan foto-foto mereka (termasuk kontak jika mungkin).

- Dalam terminologi jual-beli dan khususnya pada modus keluhan dan pengembalian barang adalah sudah biasa bagi pelanggan dan dikeluarkan secara komprehensif. (misalnya "No quibble money-back guarantee").

- Pelanggan-pelanggan hanya perlu memberikan informasi yang esensial. Seluruh detail lainnya adalah sukarela.

- $\quad$ Situs web menawarkan akses ke sebuah komunitas ketika pemasok dan produk-produk dievaluasi.

- Terdapat bukti kehandalan dari pemasok.

- Perusahaan mengindikasikan bahwa tidak ada pemberitahuan data pelanggan dan mematuhinya. 


\title{
TRUST02 Kepercayaan dari situs web dan situasi legal
}

Pertanyaan: Apakah situs web dan situasi legal ketika membeli sebuah produk menginspirasikan sebuah keyakinan?

\author{
Pilihan Anda Arti yang mungkin \\ ++ $\quad$ Situs web menginspirasikan keyakinan yang besar. \\ $+\quad$ Situs web menginspirasikan keyakinan. \\ - $\quad$ Situs web menginspirasikan sedikit keyakinan. \\ -- $\quad$ Situs web tidak menginspirasikan keyakinan sama sekali. \\ n.r. $\quad$ Kriteria tidak dapat diterapkan, tidak relevan
}

Deskripsi:

Bagi banyak pelanggan Internet belumlah cukup “aman” ketika muncul dengan penyelesaian transaksi-transaksi bisnis. Pada satu sisi rekening harus diambil dari situs web yang rusak, transmisi data yang rusak, penyalahgunaan data pribadi, serangan hacker atau virus-virus. Di sisi lain kerangka kerja yang legal dari transaksi-transaksi online sering tidak jelas. Ini secara khusus benar bagi pemasok-pemasok luar negeri.

Situasi ideal bisa terlihat seperti ini:

- Pencegahan keselamatan (misalnya encoding the transmission with SSL) haruslah diletakkan ditempatnya dan dideskripsikan.

- $\quad$ Situs web disertifikasi (misalnya oleh TRUSTe, TUV).

- Pelanggan-pelanggan diinformasikan mengenai persyaratan-persyaratan proteksi data yang legal, dan penyesuaian-penyesuaiannya dijamin.

- Terminologi jual-beli dan kondisi-kondisi legal di dalam negeri pemasok secara komprehensif dideskripsikan. 


\section{Lampiran 6 Tabel Frekuensi dan Bar Chart pada Statistik Deskriptif}

\section{Situs Web}

\begin{tabular}{|c|c|c|c|c|c|}
\hline & & Frequency & Percent & Valid Percent & Cumulative Percent \\
\hline \multirow{3}{*}{ Valid } & www.amazon.com & 20 & 20.0 & 20.0 & 20.0 \\
\cline { 2 - 6 } & www.balaipustakaonline.com & 20 & 20.0 & 20.0 & 40.0 \\
\cline { 2 - 6 } & www.erlangga.co.id & 20 & 20.0 & 20.0 & 60.0 \\
\cline { 2 - 6 } & www.gramediaonline.com & 20 & 20.0 & 20.0 & 80.0 \\
\cline { 2 - 6 } & www.kutukutubuku.com & 20 & 20.0 & 20.0 & 100.0 \\
\cline { 2 - 6 } & Total & 100 & 100.0 & 100.0 & \\
\hline
\end{tabular}

\section{Situs Web}

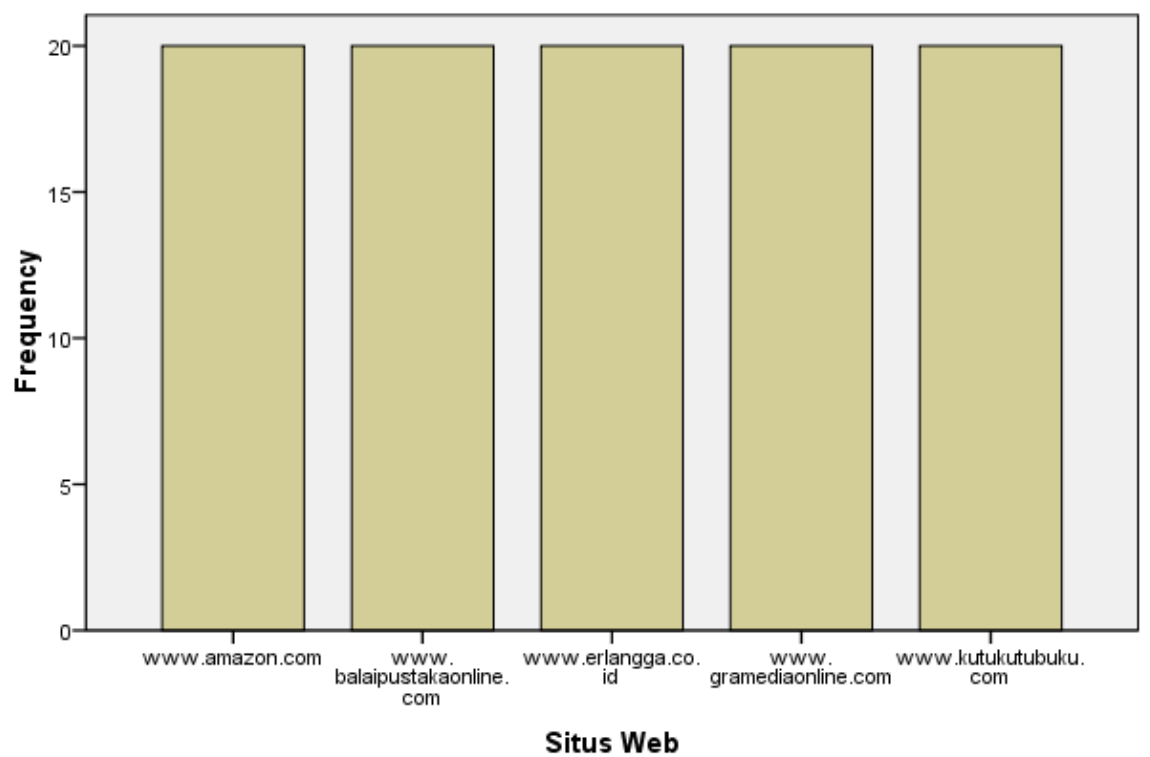


1. Fase Informasi (Information Phase) [Kemudahan akses dari situs web dan produk-produknya (EOU01)]

\begin{tabular}{|c|c|c|c|c|c|}
\hline & & Frequency & Percent & Valid Percent & Cumulative Percent \\
\hline Valid & -2 & 3 & 3.0 & 3.1 & 3.1 \\
\cline { 2 - 6 } & -1 & 7 & 7.0 & 7.2 & 10.3 \\
\cline { 2 - 6 } & 1 & 49 & 49.0 & 50.5 & 60.8 \\
\cline { 2 - 6 } & 2 & 38 & 38.0 & 39.2 & 100.0 \\
\cline { 2 - 6 } & Total & 97 & 97.0 & 100.0 & \\
\hline Missing & System & 3 & 3.0 & & \\
\hline \multicolumn{7}{|l}{ Total } & 100 & 100.0 & & \\
\hline
\end{tabular}

1. Fase Informasi (Information Phase) [Kemudahan akses dari situs web dan produk-1produknya (EOU01)]

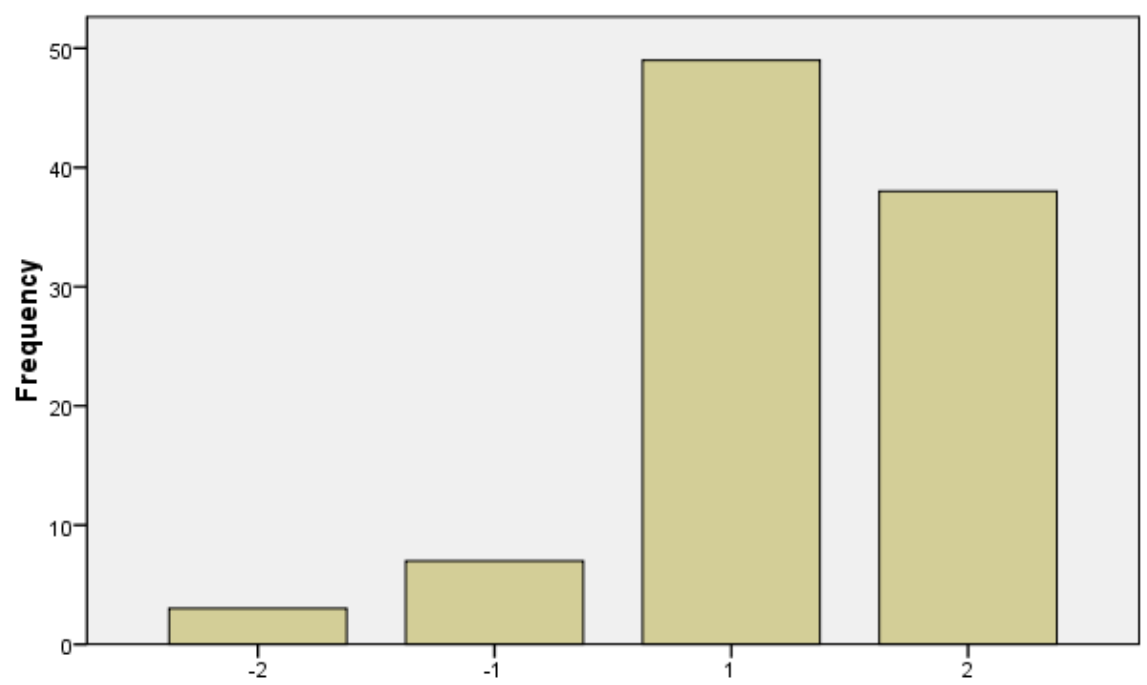

1. Fase Informasi (Information Phase) [Kemudahan akses dari situs web dan produk-1produknya (EOU01)] 
1. Fase Informasi (Information Phase) [Struktur isi (EOU02)]

\begin{tabular}{|c|c|c|c|c|c|}
\hline \multirow{3}{*}{ Valid } & & Frequency & Percent & Valid Percent & Cumulative Percent \\
\cline { 2 - 6 } & -1 & 8 & 8.0 & 8.2 & 8.2 \\
\cline { 2 - 6 } & 1 & 58 & 58.0 & 59.8 & 68.0 \\
\cline { 2 - 6 } & 2 & 31 & 31.0 & 32.0 & 100.0 \\
\hline & Total & 97 & 97.0 & 100.0 & \\
\hline Missing & System & 3 & 3.0 & & \\
\hline \multicolumn{2}{|r}{ Total } & 100 & 100.0 & & \\
\hline
\end{tabular}

1. Fase Informasi (Information Phase) [Struktur isi (EOU02)]

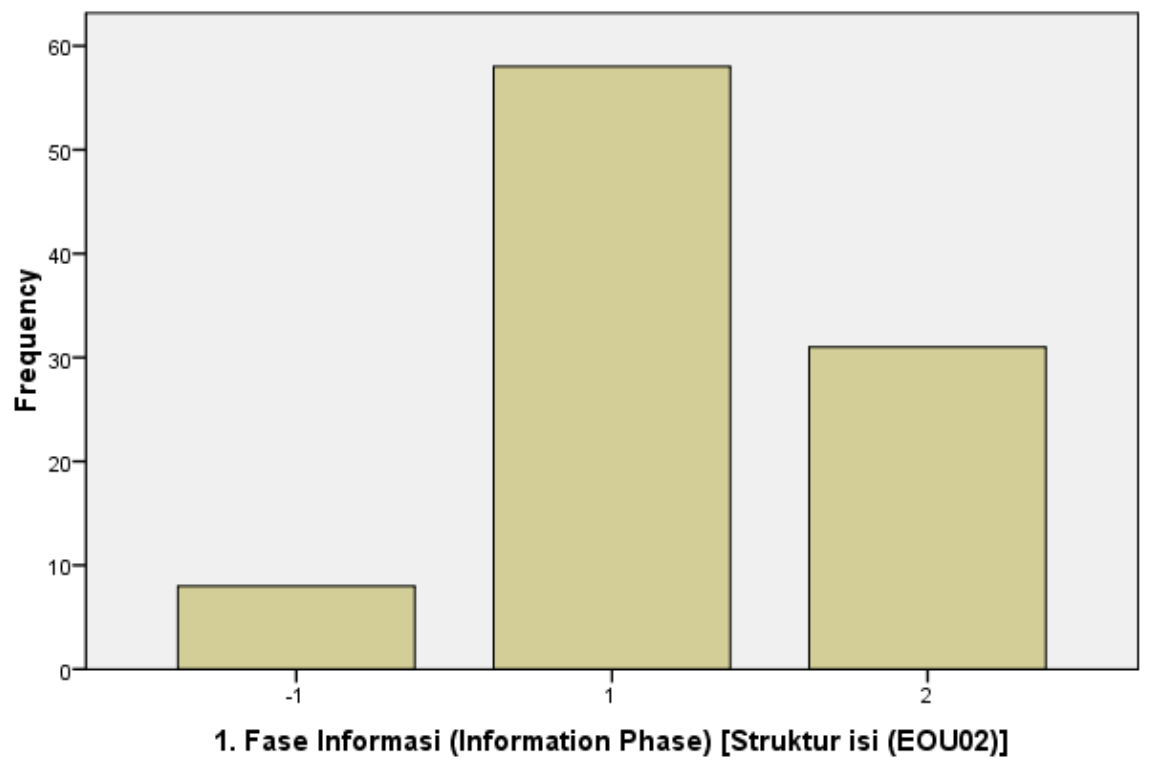


1. Fase Informasi (Information Phase) [Kuantitas informasi (EOU03)]

\begin{tabular}{|c|c|c|c|c|c|}
\hline \multirow{3}{*}{ Valid } & & Frequency & Percent & Valid Percent & Cumulative Percent \\
\cline { 2 - 6 } & -2 & 1 & 1.0 & 1.0 & 1.0 \\
\cline { 2 - 6 } & -1 & 9 & 9.0 & 9.3 & 10.3 \\
\cline { 2 - 6 } & 1 & 57 & 57.0 & 58.8 & 69.1 \\
\cline { 2 - 6 } & 2 & 30 & 30.0 & 30.9 & 100.0 \\
\hline \multicolumn{1}{|c|}{ Missing } & Sotal & 97 & 97.0 & 100.0 & \\
\hline \multicolumn{2}{|c|}{ Total } & 100 & 100.0 & & \\
\hline
\end{tabular}

\section{Fase Informasi (Information Phase) [Kuantitas informasi (EOU03)]}

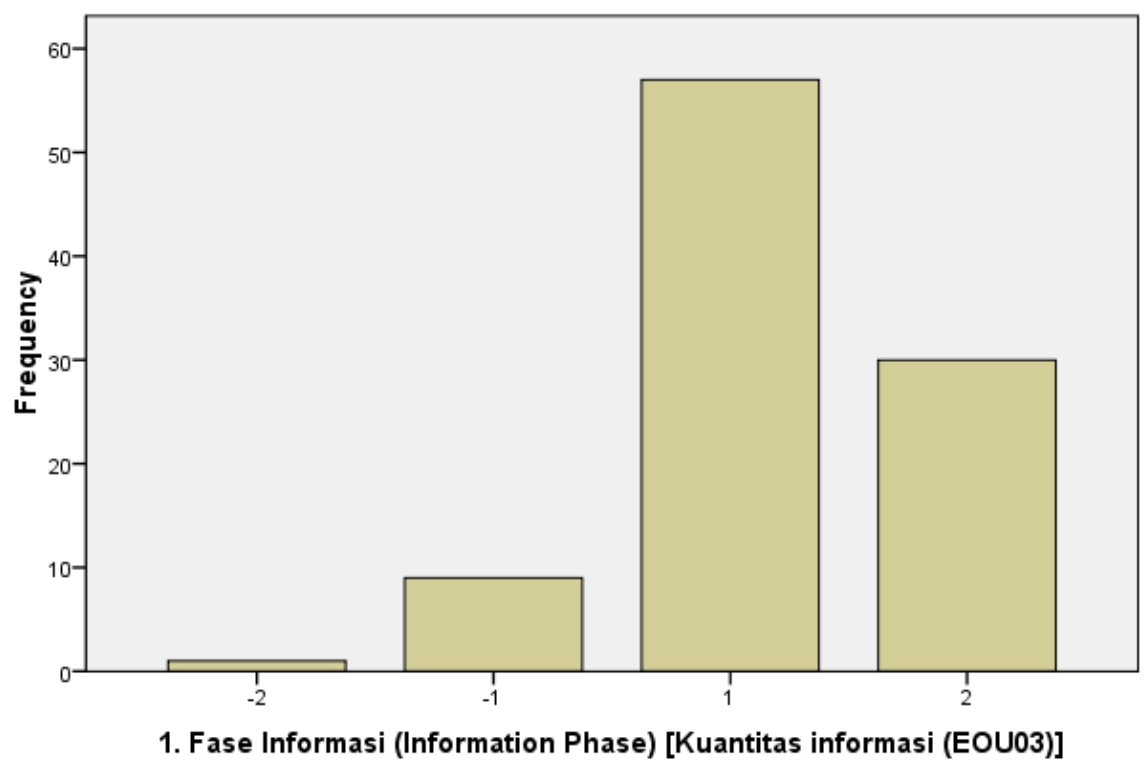


1. Fase Informasi (Information Phase) [Kualitas isi (USEF01)]

\begin{tabular}{|c|c|c|c|c|c|}
\hline \multirow{3}{*}{ Valid } & & Frequency & Percent & Valid Percent & Cumulative Percent \\
\cline { 2 - 6 } & -2 & 3 & 3.0 & 3.1 & 3.1 \\
\cline { 2 - 6 } & -1 & 10 & 10.0 & 10.3 & 13.4 \\
\cline { 2 - 6 } & 2 & 56 & 56.0 & 57.7 & 71.1 \\
\cline { 2 - 6 } & 2 & 28 & 28.0 & 28.9 & 100.0 \\
\hline \multicolumn{1}{|c|}{ Missing } & Sotal & 97 & 97.0 & 100.0 & \\
\hline \multicolumn{7}{|c|}{ System } & 3 & 3.0 & & \\
\hline
\end{tabular}

1. Fase Informasi (Information Phase) [Kualitas isi (USEF01)]

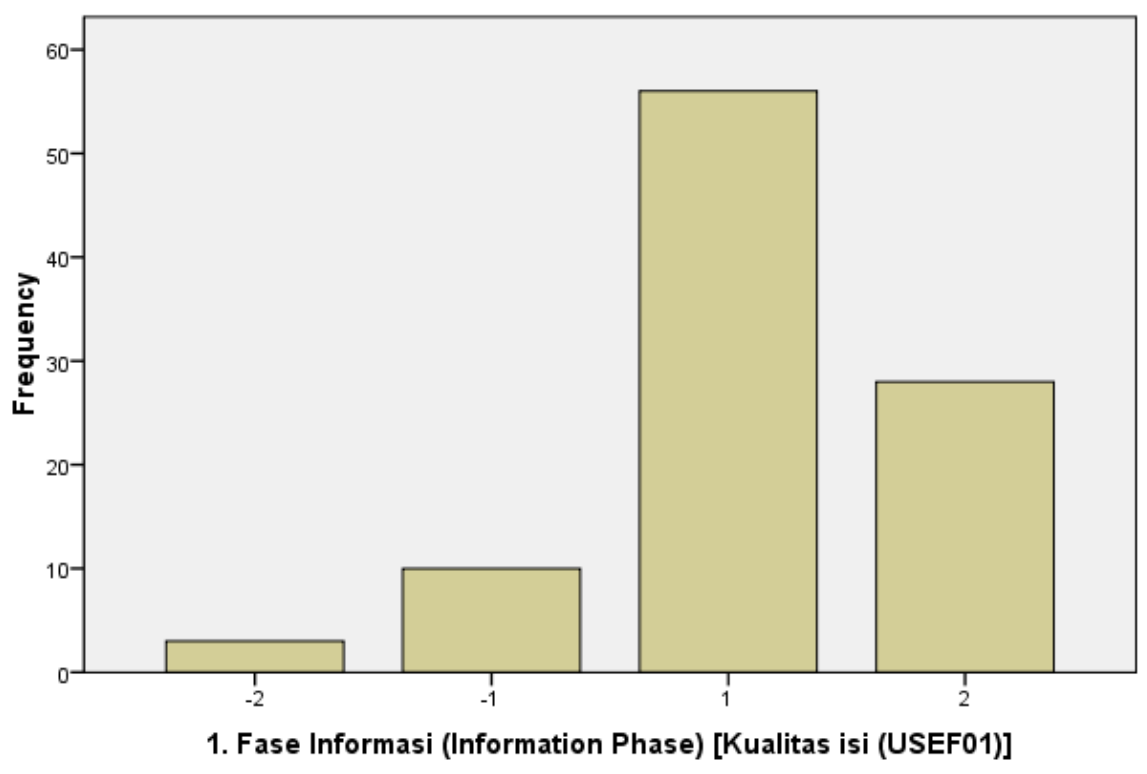


1. Fase Informasi (Information Phase) [Menyampaikan manfaat-manfaat dari harga (USEF02)]

\begin{tabular}{|c|c|c|c|c|c|}
\hline & & Frequency & Percent & Valid Percent & Cumulative Percent \\
\hline \multirow[t]{5}{*}{ Valid } & -2 & 2 & 2.0 & 2.1 & 2.1 \\
\hline & -1 & 25 & 25.0 & 25.8 & 27.8 \\
\hline & 1 & 43 & 43.0 & 44.3 & 72.2 \\
\hline & 2 & 27 & 27.0 & 27.8 & 100.0 \\
\hline & Total & 97 & 97.0 & 100.0 & \\
\hline Missing & System & 3 & 3.0 & & \\
\hline \multicolumn{2}{|c|}{ Total } & 100 & 100.0 & & \\
\hline
\end{tabular}

1. Fase Informasi (Information Phase) [Menyampaikan manfaat-1manfaat dari harga (USEF02)]

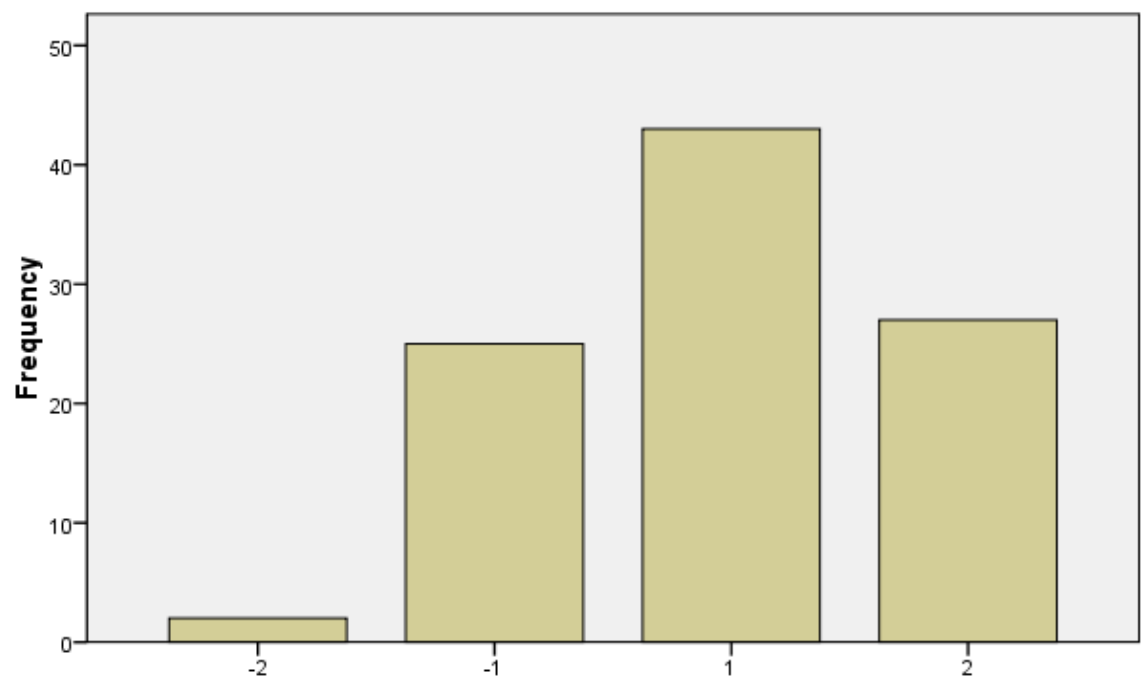

1. Fase Informasi (Information Phase) [Menyampaikan manfaat-1manfaat dari harga (USEF02)] 
1. Fase Informasi (Information Phase) [Membundel produk-produk dan layanan-layanannya (USEF03)]

\begin{tabular}{|c|c|c|c|c|c|}
\hline & & Frequency & Percent & Valid Percent & Cumulative Percent \\
\hline \multirow[t]{6}{*}{ Valid } & -2 & 7 & 7.0 & 7.2 & 7.2 \\
\hline & -1 & 22 & 22.0 & 22.7 & 29.9 \\
\hline & 0 & 1 & 1.0 & 1.0 & 30.9 \\
\hline & 1 & 48 & 48.0 & 49.5 & 80.4 \\
\hline & 2 & 19 & 19.0 & 19.6 & 100.0 \\
\hline & Total & 97 & 97.0 & 100.0 & \\
\hline Missing & System & 3 & 3.0 & & \\
\hline \multicolumn{2}{|c|}{ Total } & 100 & 100.0 & & \\
\hline
\end{tabular}

1. Fase Informasi (Information Phase) [Sistem-sistem rekomendasi (USEF04)]

\begin{tabular}{|c|c|c|c|c|c|}
\hline & & Frequency & Percent & Valid Percent & Cumulative Percent \\
\hline \multirow[t]{6}{*}{ Valid } & -2 & 10 & 10.0 & 10.3 & 10.3 \\
\hline & -1 & 27 & 27.0 & 27.8 & 38.1 \\
\hline & 0 & 1 & 1.0 & 1.0 & 39.2 \\
\hline & 1 & 45 & 45.0 & 46.4 & 85.6 \\
\hline & 2 & 14 & 14.0 & 14.4 & 100.0 \\
\hline & Total & 97 & 97.0 & 100.0 & \\
\hline Missing & System & 3 & 3.0 & & \\
\hline \multicolumn{2}{|c|}{ Total } & 100 & 100.0 & & \\
\hline
\end{tabular}

\section{Fase Informasi (Information Phase) [Sistem-1 sistem rekomendasi (USEF04)]}

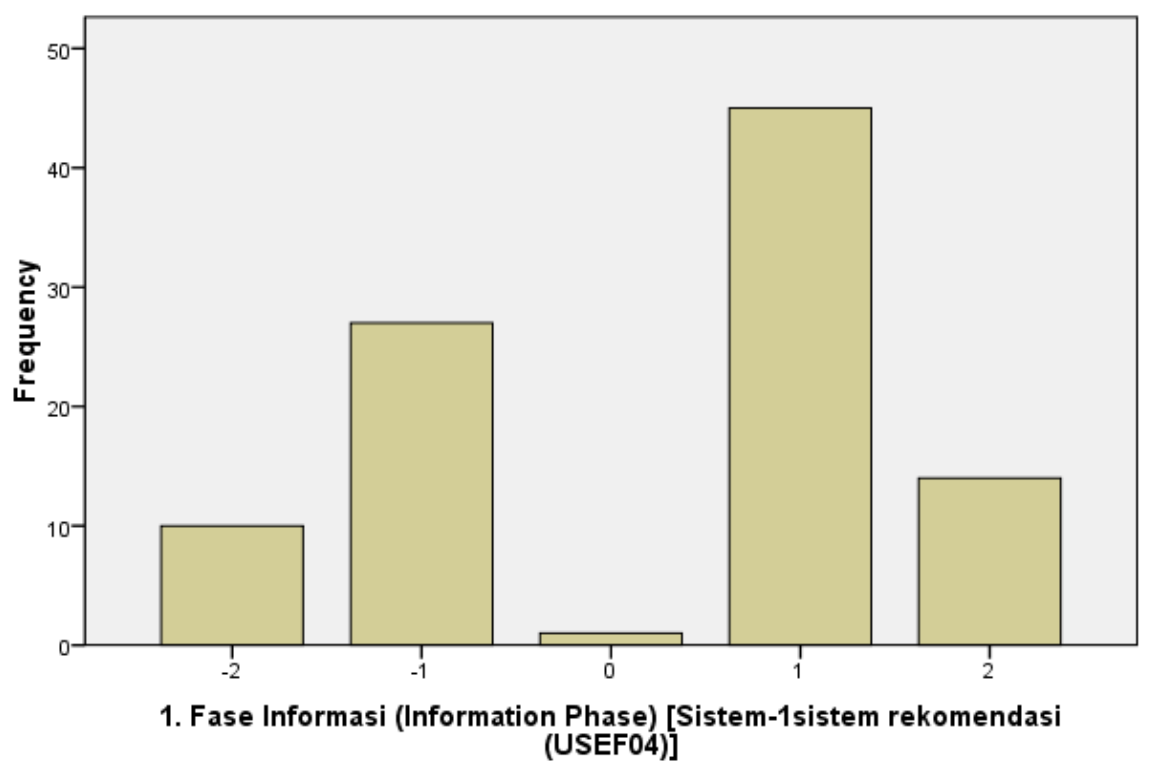


1. Fase Informasi (Information Phase) [Menggunakan hypermedia (USEF05)]

\begin{tabular}{|c|c|c|c|c|c|}
\hline \multirow{3}{*}{ Valid } & & Frequency & Percent & Valid Percent & Cumulative Percent \\
\cline { 2 - 6 } & -2 & 8 & 8.0 & 8.2 & 8.2 \\
\cline { 2 - 6 } & -1 & 24 & 24.0 & 24.7 & 33.0 \\
\cline { 2 - 6 } & 0 & 6 & 6.0 & 6.2 & 39.2 \\
\cline { 2 - 6 } & 1 & 37 & 37.0 & 38.1 & 77.3 \\
\cline { 2 - 6 } & 2 & 22 & 22.0 & 22.7 & 100.0 \\
\hline Missing & Total & 97 & 97.0 & 100.0 & \\
\hline \multicolumn{6}{|c|}{ System } \\
\hline
\end{tabular}

1. Fase Informasi (Information Phase) [Menggunakan hypermedia (USEF05)]

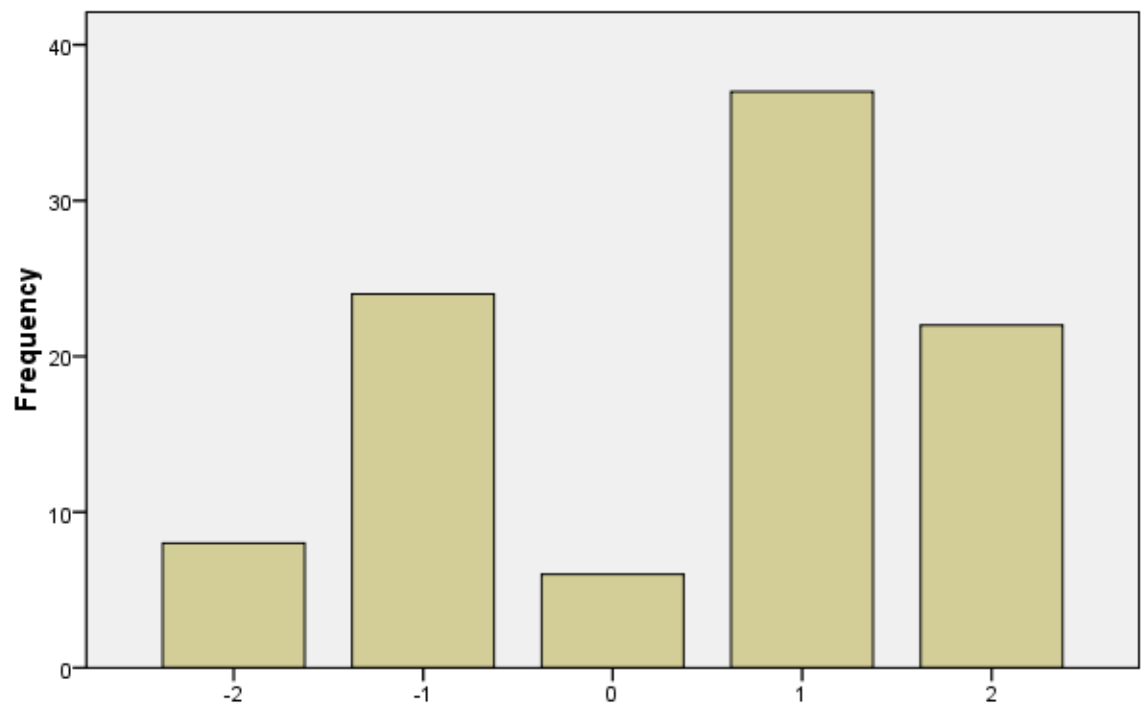

1. Fase Informasi (Information Phase) [Menggunakan hypermedia (USEF05)] 
2. Fase Kesepakatan (Agreement Phase) [Desain dari prosedur pemesanan (EOU04)]

\begin{tabular}{|c|c|c|c|c|c|}
\hline & & Frequency & Percent & Valid Percent & Cumulative Percent \\
\hline \multirow[t]{4}{*}{ Valid } & -1 & 13 & 13.0 & 13.4 & 13.4 \\
\hline & 1 & 59 & 59.0 & 60.8 & 74.2 \\
\hline & 2 & 25 & 25.0 & 25.8 & 100.0 \\
\hline & Total & 97 & 97.0 & 100.0 & \\
\hline Missing & System & 3 & 3.0 & & \\
\hline \multicolumn{2}{|c|}{ Total } & 100 & 100.0 & & \\
\hline
\end{tabular}

2. Fase Kesepakatan (Agreement Phase) [Desain dari prosedur pemesanan (EOU04)]

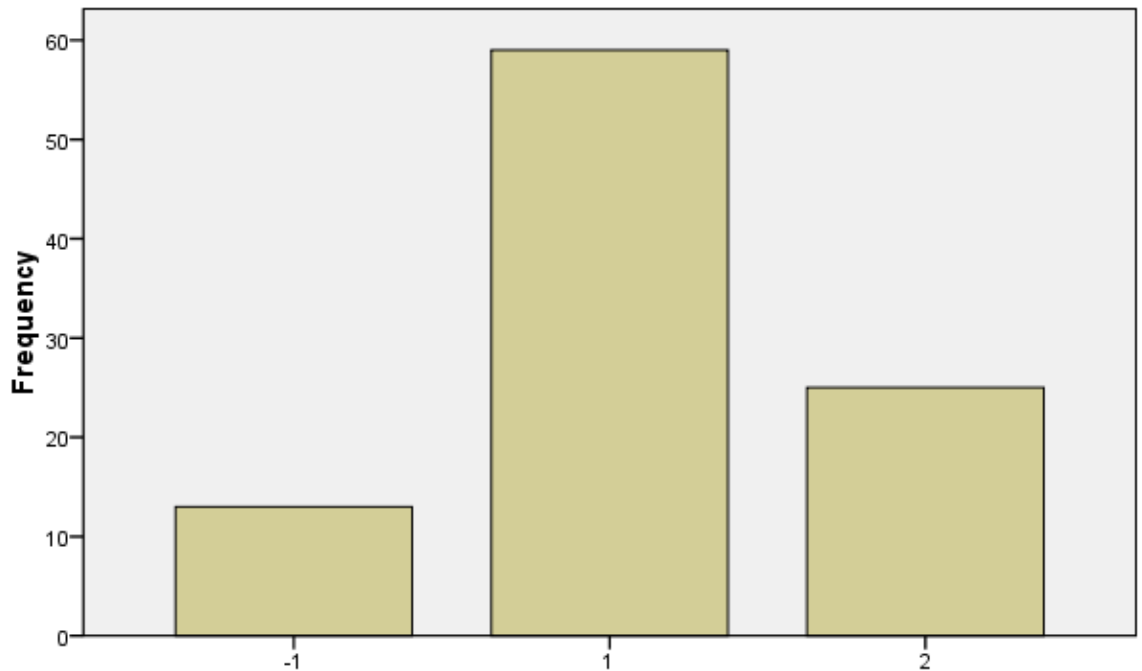

2. Fase Kesepakatan (Agreement Phase) [Desain dari prosedur pemesanan (EOU04)] 
2. Fase Kesepakatan (Agreement Phase) [Model-model dan metode-metode penetapan harga (USEF06)]

\begin{tabular}{|c|c|c|c|c|c|}
\hline & & Frequency & Percent & Valid Percent & Cumulative Percent \\
\hline \multirow[t]{6}{*}{ Valid } & -2 & 1 & 1.0 & 1.0 & 1.0 \\
\hline & -1 & 19 & 19.0 & 19.6 & 20.6 \\
\hline & 0 & 2 & 2.0 & 2.1 & 22.7 \\
\hline & 1 & 59 & 59.0 & 60.8 & 83.5 \\
\hline & 2 & 16 & 16.0 & 16.5 & 100.0 \\
\hline & Total & 97 & 97.0 & 100.0 & \\
\hline Missing & System & 3 & 3.0 & & \\
\hline \multicolumn{2}{|c|}{ Total } & 100 & 100.0 & & \\
\hline
\end{tabular}

2. Fase Kesepakatan (Agreement Phase) [Model-1model dan metode-1metode penetapan harga (USEF06)]

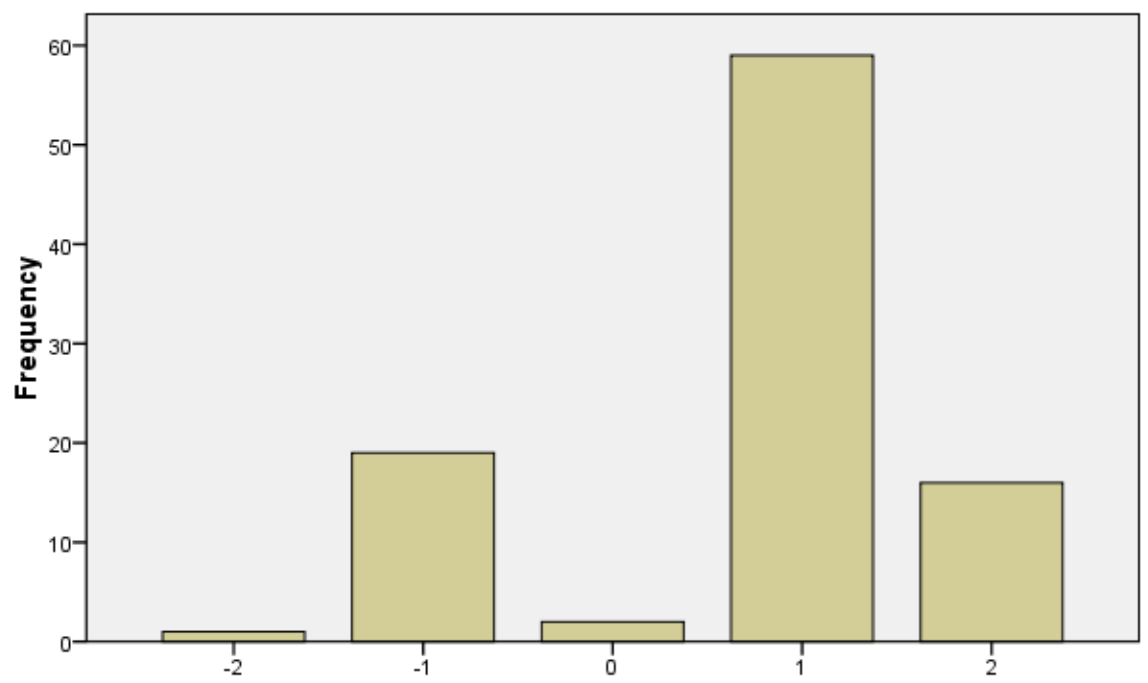

2. Fase Kesepakatan (Agreement Phase) [Model-1model dan metode1 metode penetapan harga (USEF06)] 
3. Fase Penyelesaian (Settlement Phase) [Integrasi dari layanan-layanan umum (EOU05)]

\begin{tabular}{|c|c|c|c|c|c|}
\hline & & Frequency & Percent & Valid Percent & Cumulative Percent \\
\hline \multirow[t]{5}{*}{ Valid } & -2 & 7 & 7.0 & 7.2 & 7.2 \\
\hline & -1 & 22 & 22.0 & 22.7 & 29.9 \\
\hline & 1 & 51 & 51.0 & 52.6 & 82.5 \\
\hline & 2 & 17 & 17.0 & 17.5 & 100.0 \\
\hline & Total & 97 & 97.0 & 100.0 & \\
\hline Missing & System & 3 & 3.0 & & \\
\hline \multicolumn{2}{|c|}{ Total } & 100 & 100.0 & & \\
\hline
\end{tabular}

3. Fase Penyelesaian (Settlement Phase) [Integrasi dari layanan-1layanan umum (EOUD5)]

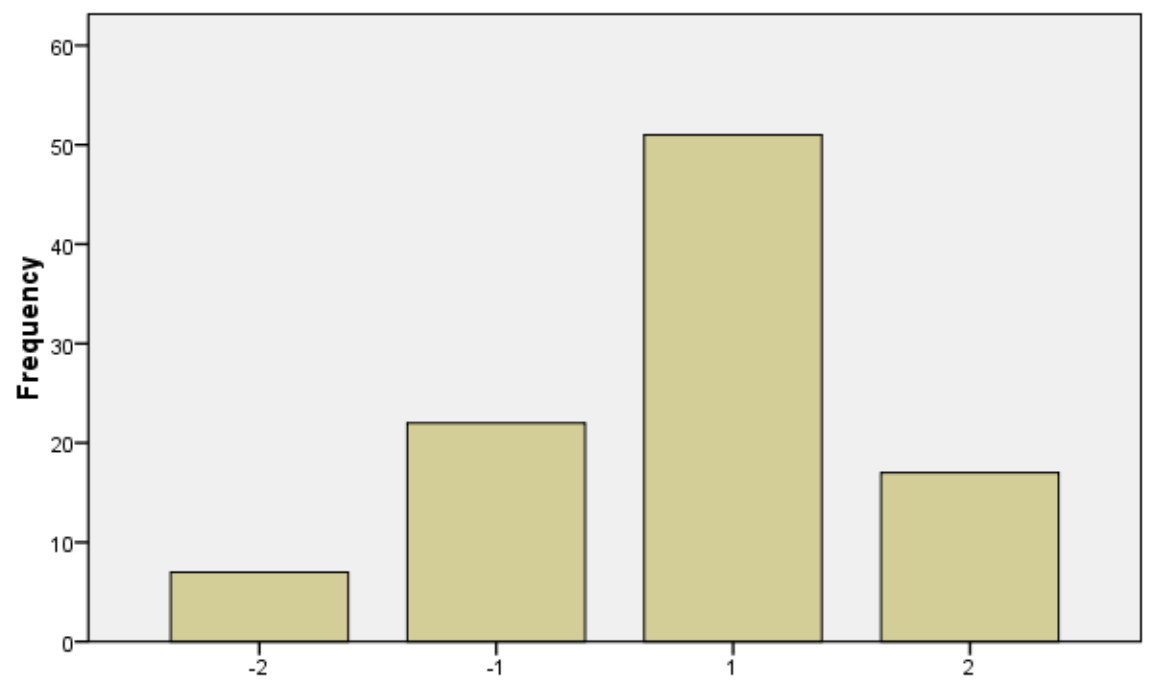

3. Fase Penyelesaian (Settlement Phase) [Integrasi dari layanan-1layanan umum (EOU05)] 
3. Fase Penyelesaian (Settlement Phase) [Integrasi dari aplikasi-aplikasi $e$ commerce (USEF07)]

\begin{tabular}{|c|c|c|c|c|c|}
\hline & & Frequency & Percent & Valid Percent & Cumulative Percent \\
\hline \multirow[t]{6}{*}{ Valid } & -2 & 9 & 9.0 & 9.3 & 9.3 \\
\hline & -1 & 22 & 22.0 & 22.7 & 32.0 \\
\hline & 0 & 1 & 1.0 & 1.0 & 33.0 \\
\hline & 1 & 47 & 47.0 & 48.5 & 81.4 \\
\hline & 2 & 18 & 18.0 & 18.6 & 100.0 \\
\hline & Total & 97 & 97.0 & 100.0 & \\
\hline Missing & System & 3 & 3.0 & & \\
\hline \multicolumn{2}{|c|}{ Total } & 100 & 100.0 & & \\
\hline
\end{tabular}

3. Fase Penyelesaian (Settlement Phase) [Integrasi dari aplikasi-1 aplikasi e1commerce (USEFO7)]

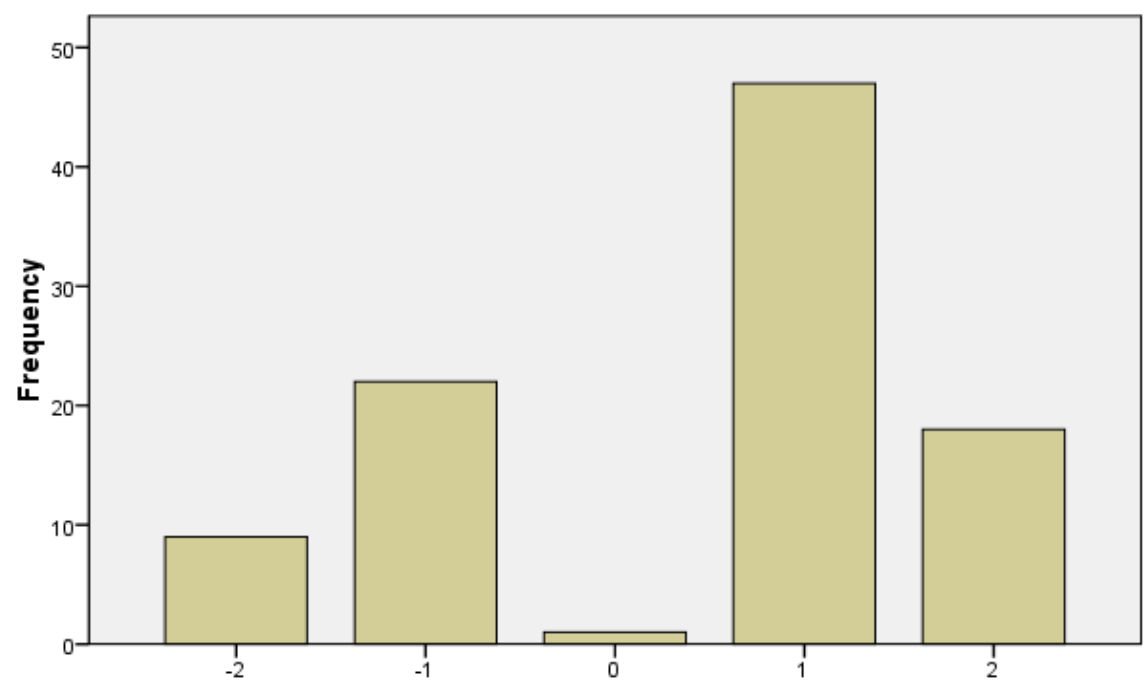

3. Fase Penyelesaian (Settlement Phase) [Integrasi dari aplikasi-1aplikasi e1commerce (USEF07)] 
3. Fase Penyelesaian (Settlement Phase) [Perutean dan penelusuran (USEF08)]

\begin{tabular}{|c|c|c|c|c|c|}
\hline & & Frequency & Percent & Valid Percent & Cumulative Percent \\
\hline \multirow[t]{6}{*}{ Valid } & -2 & 9 & 9.0 & 9.3 & 9.3 \\
\hline & -1 & 22 & 22.0 & 22.7 & 32.0 \\
\hline & 0 & 1 & 1.0 & 1.0 & 33.0 \\
\hline & 1 & 44 & 44.0 & 45.4 & 78.4 \\
\hline & 2 & 21 & 21.0 & 21.6 & 100.0 \\
\hline & Total & 97 & 97.0 & 100.0 & \\
\hline Missing & System & 3 & 3.0 & & \\
\hline \multicolumn{2}{|c|}{ Total } & 100 & 100.0 & & \\
\hline
\end{tabular}

3. Fase Penyelesaian (Settlement Phase) [Perutean dan penelusuran (USEF08)]

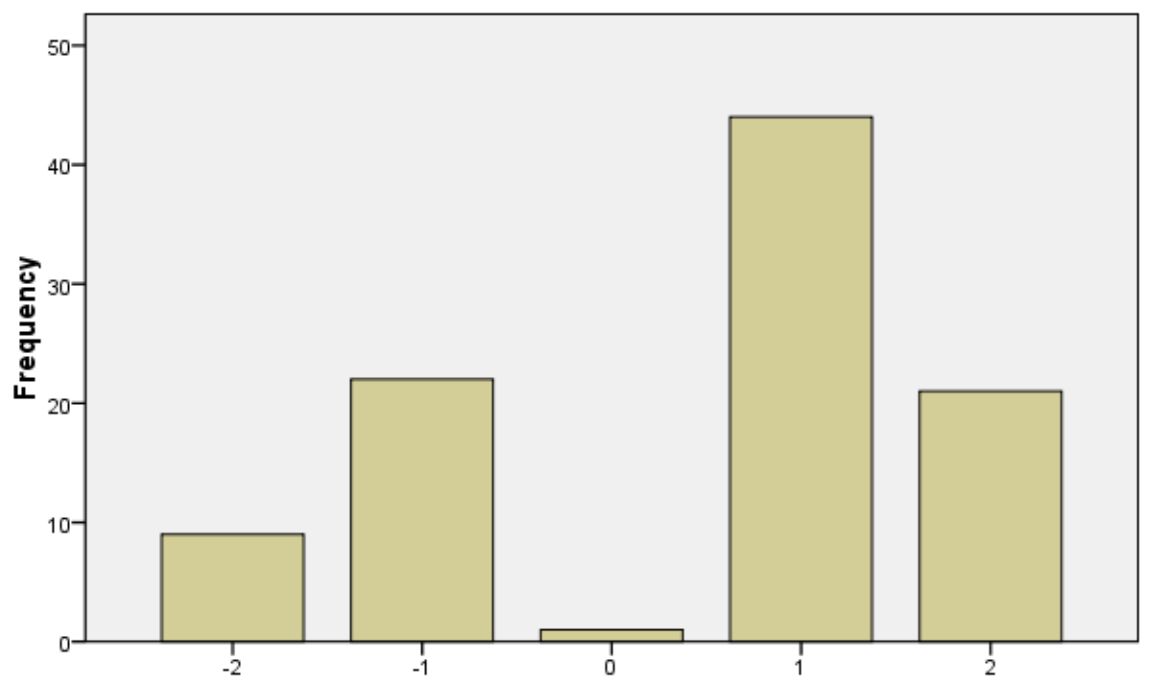

3. Fase Penyelesaian (Settlement Phase) [Perutean dan penelusuran (USEF08)] 
4. Fase Setelah-Penjualan (After-Sales Phase) [Akses kepada dukungan pelanggan (EOU06)]

\begin{tabular}{|c|c|c|c|c|c|}
\hline & & Frequency & Percent & Valid Percent & Cumulative Percent \\
\hline \multirow[t]{6}{*}{ Valid } & -2 & 7 & 7.0 & 7.2 & 7.2 \\
\hline & -1 & 21 & 21.0 & 21.6 & 28.9 \\
\hline & 0 & 2 & 2.0 & 2.1 & 30.9 \\
\hline & 1 & 51 & 51.0 & 52.6 & 83.5 \\
\hline & 2 & 16 & 16.0 & 16.5 & 100.0 \\
\hline & Total & 97 & 97.0 & 100.0 & \\
\hline Missing & System & 3 & 3.0 & & \\
\hline \multicolumn{2}{|c|}{ Total } & 100 & 100.0 & & \\
\hline
\end{tabular}

4. Fase Setelah-1Penjualan (After-1Sales Phase) [Akses kepada dukungan pelanggan (EOU06)]

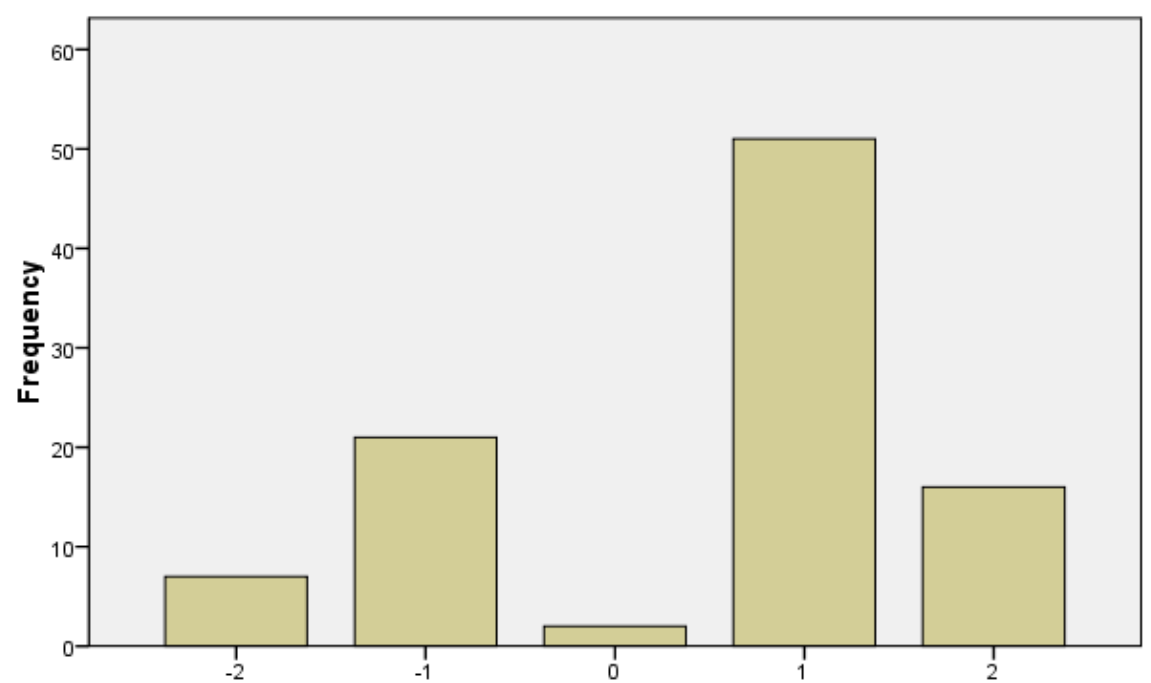

4. Fase Setelah-1Penjualan (After-1Sales Phase) [Akses kepada dukungan pelanggan (EOU06)] 
4. Fase Setelah-Penjualan (After-Sales Phase) [Kinerja dari dukungan pelanggan (USEF09)]

\begin{tabular}{|c|c|c|c|c|c|}
\hline & & Frequency & Percent & Valid Percent & Cumulative Percent \\
\hline \multirow[t]{6}{*}{ Valid } & -2 & 9 & 9.0 & 9.3 & 9.3 \\
\hline & -1 & 26 & 26.0 & 26.8 & 36.1 \\
\hline & 0 & 2 & 2.0 & 2.1 & 38.1 \\
\hline & 1 & 45 & 45.0 & 46.4 & 84.5 \\
\hline & 2 & 15 & 15.0 & 15.5 & 100.0 \\
\hline & Total & 97 & 97.0 & 100.0 & \\
\hline Missing & System & 3 & 3.0 & & \\
\hline \multicolumn{2}{|c|}{ Total } & 100 & 100.0 & & \\
\hline
\end{tabular}

4. Fase Setelah-1Penjualan (After-1Sales Phase) [Kinerja dari dukungan pelanggan (USEF09)]

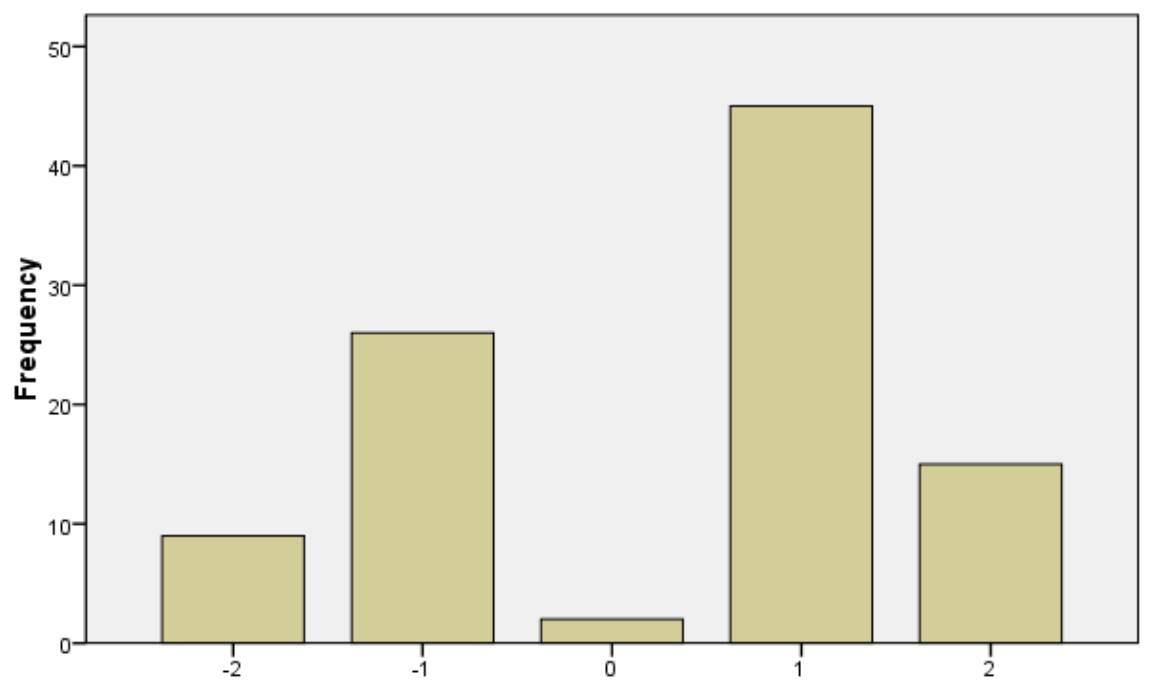

4. Fase Setelah-1Penjualan (After-1Sales Phase) [Kinerja dari dukungan pelanggan (USEF09)] 
5. Komponen Komunitas (Community Component) [Akses ke sebuah komunitas virtual (EOU07)]

\begin{tabular}{|c|c|c|c|c|c|}
\hline & & Frequency & Percent & Valid Percent & Cumulative Percent \\
\hline \multirow[t]{6}{*}{ Valid } & -2 & 13 & 13.0 & 13.4 & 13.4 \\
\hline & -1 & 27 & 27.0 & 27.8 & 41.2 \\
\hline & 0 & 7 & 7.0 & 7.2 & 48.5 \\
\hline & 1 & 41 & 41.0 & 42.3 & 90.7 \\
\hline & 2 & 9 & 9.0 & 9.3 & 100.0 \\
\hline & Total & 97 & 97.0 & 100.0 & \\
\hline Missing & System & 3 & 3.0 & & \\
\hline \multicolumn{2}{|c|}{ Total } & 100 & 100.0 & & \\
\hline
\end{tabular}

5. Komponen Komunitas (Community Component) [Akses ke sebuah komunitas virtual (EOU07)]

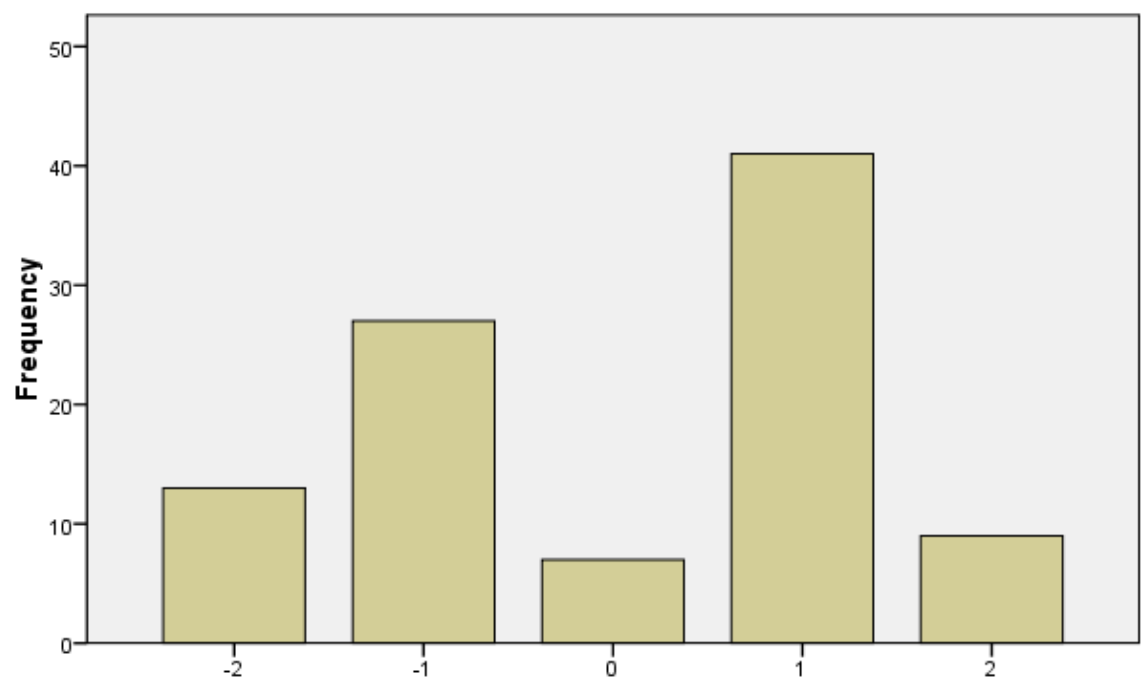

5. Komponen Komunitas (Community Component) [Akses ke sebuah komunitas virtual (EOU07)] 
5. Komponen Komunitas (Community Component) [Keuntungan dari relasirelasi di dalam komunitas (USEF10)]

\begin{tabular}{|c|c|c|c|c|c|}
\hline & & Frequency & Percent & Valid Percent & Cumulative Percent \\
\hline \multirow[t]{6}{*}{ Valid } & -2 & 12 & 12.0 & 12.4 & 12.4 \\
\hline & -1 & 25 & 25.0 & 25.8 & 38.1 \\
\hline & 0 & 10 & 10.0 & 10.3 & 48.5 \\
\hline & 1 & 39 & 39.0 & 40.2 & 88.7 \\
\hline & 2 & 11 & 11.0 & 11.3 & 100.0 \\
\hline & Total & 97 & 97.0 & 100.0 & \\
\hline Missing & System & 3 & 3.0 & & \\
\hline \multicolumn{2}{|c|}{ Total } & 100 & 100.0 & & \\
\hline
\end{tabular}

5. Komponen Komunitas (Community Component) [Keuntungan dari relasi1 relasi didalam komunitas (USEF10)]

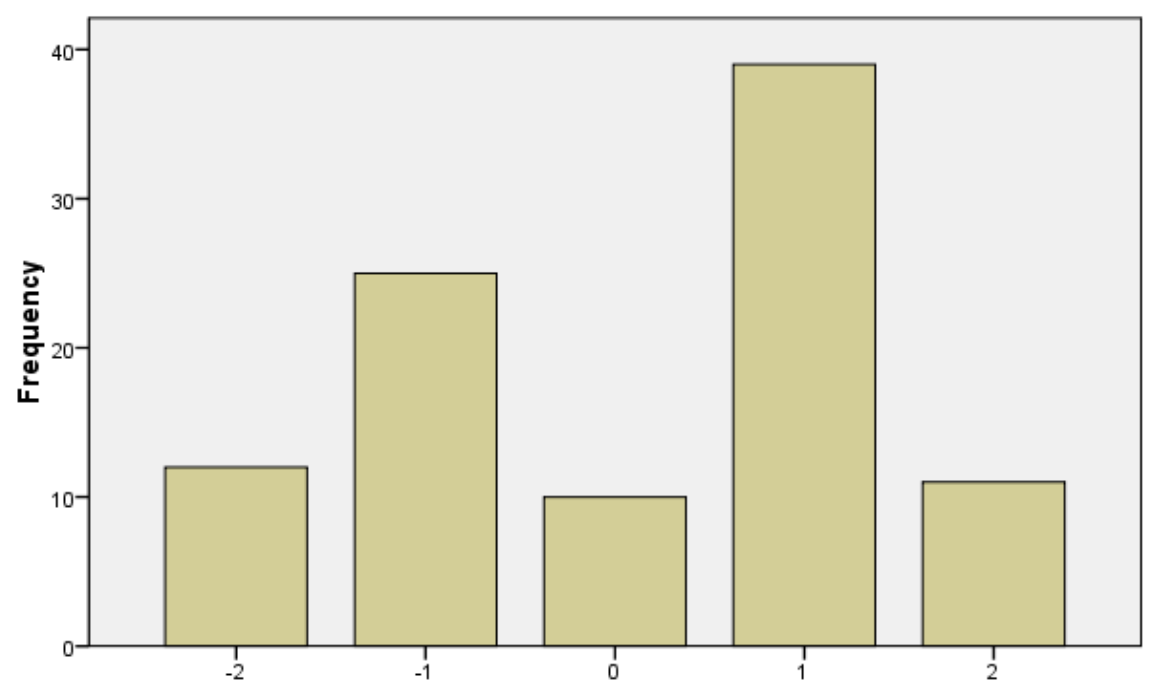

5. Komponen Komunitas (Community Component) [Keuntungan dari relasi1relasi didalam komunitas (USEF10)] 
5. Komponen Komunitas (Community Component) [Keuntungan dari ketersediaan isi di dalam komunitas (USEF11)]

\begin{tabular}{|c|c|c|c|c|c|}
\hline & & Frequency & Percent & Valid Percent & Cumulative Percent \\
\hline Valid & -2 & 12 & 12.0 & 12.4 & 12.4 \\
\cline { 2 - 6 } & -1 & 26 & 26.0 & 26.8 & 39.2 \\
\cline { 2 - 6 } & 0 & 10 & 10.0 & 10.3 & 49.5 \\
\cline { 2 - 6 } & 1 & 39 & 39.0 & 40.2 & 89.7 \\
\cline { 2 - 6 } & 2 & 10 & 10.0 & 10.3 & 100.0 \\
\cline { 2 - 6 } & Total & 97 & 97.0 & 100.0 & \\
\hline Missing & System & 3 & 3.0 & & \\
\hline \multicolumn{6}{|l}{ Total } \\
\hline
\end{tabular}

5. Komponen Komunitas (Community Component) [Keuntungan dari ketersediaan isi didalam komunitas (USEF11)]

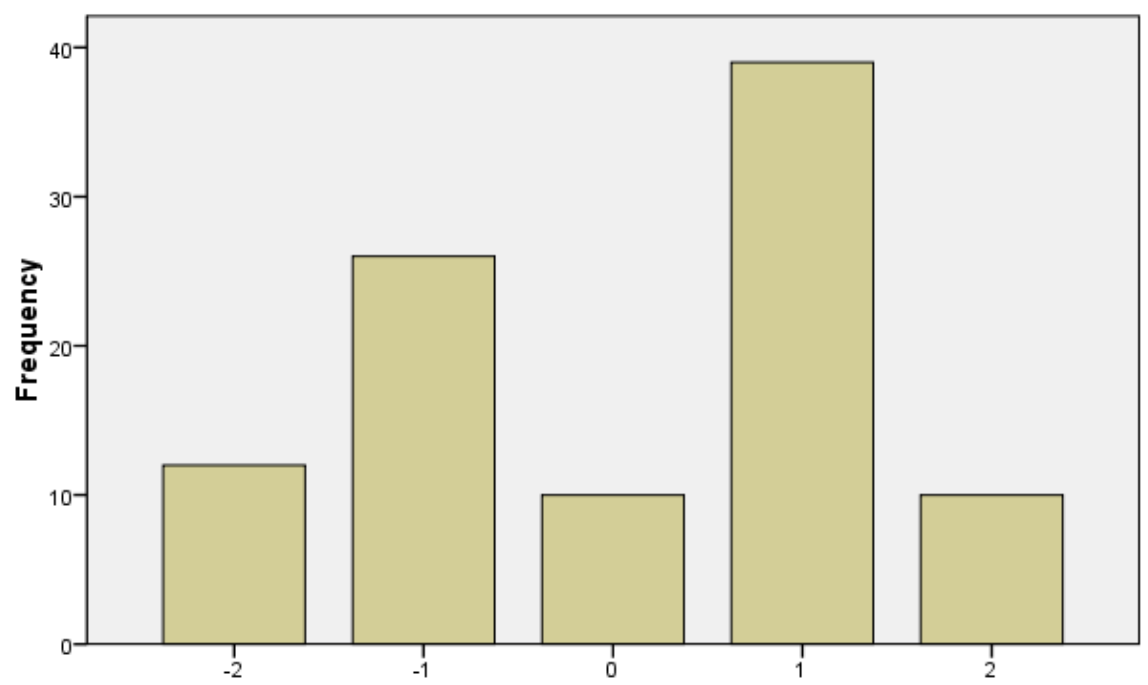

5. Komponen Komunitas (Community Component) [Keuntungan dari ketersediaan isi didalam komunitas (USEF11)] 
5. Komponen Komunitas (Community Component) [Pemberdayaan pelanggan yang dihasilkan dari komunitas (USEF12)]

\begin{tabular}{|c|c|c|c|c|c|}
\hline & & Frequency & Percent & Valid Percent & Cumulative Percent \\
\hline \multirow[t]{6}{*}{ Valid } & -2 & 14 & 14.0 & 14.4 & 14.4 \\
\hline & -1 & 25 & 25.0 & 25.8 & 40.2 \\
\hline & 0 & 10 & 10.0 & 10.3 & 50.5 \\
\hline & 1 & 34 & 34.0 & 35.1 & 85.6 \\
\hline & 2 & 14 & 14.0 & 14.4 & 100.0 \\
\hline & Total & 97 & 97.0 & 100.0 & \\
\hline Missing & System & 3 & 3.0 & & \\
\hline \multicolumn{2}{|c|}{ Total } & 100 & 100.0 & & \\
\hline
\end{tabular}

5. Komponen Komunitas (Community Component) [Pemberdayaan pelanggan yang dihasilkan dari komunitas (USEF12)]

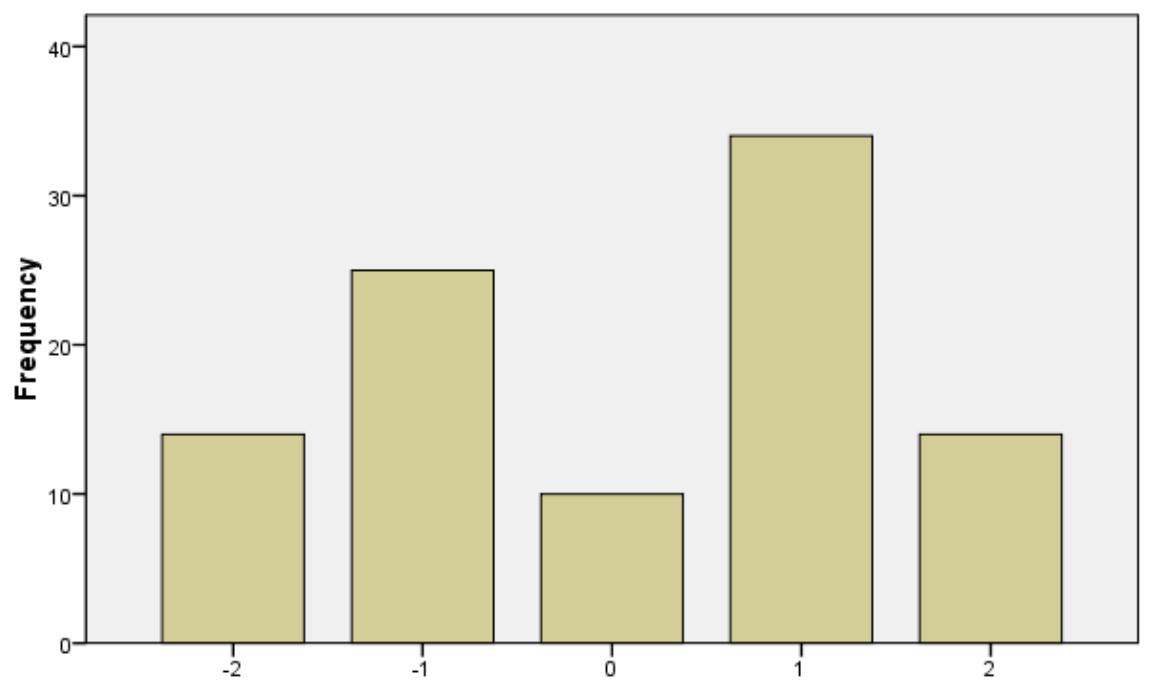

5. Komponen Komunitas (Community Component) [Pemberdayaan pelanggan yang dihasilkan dari komunitas (USEF12)] 
6. Bagian Akhir (Final Section) [Ketersediaan sistem (EOU08)]

\begin{tabular}{|c|c|c|c|c|c|}
\hline \multirow{3}{*}{ Valid } & & Frequency & Percent & Valid Percent & Cumulative Percent \\
\cline { 2 - 6 } & -2 & 3 & 3.0 & 3.1 & 3.1 \\
\cline { 2 - 6 } & -1 & 10 & 10.0 & 10.3 & 13.4 \\
\cline { 2 - 6 } & 1 & 56 & 56.0 & 57.7 & 71.1 \\
\cline { 2 - 6 } & 2 & 28 & 28.0 & 28.9 & 100.0 \\
\cline { 2 - 6 } & Total & 97 & 97.0 & 100.0 & \\
\hline Missing & System & 3 & 3.0 & & \\
\hline \multicolumn{7}{|l}{ Total } & 100 & 100.0 & & \\
\hline
\end{tabular}

\section{Bagian Akhir (Final Section) [Ketersediaan sistem (EOU08)]}

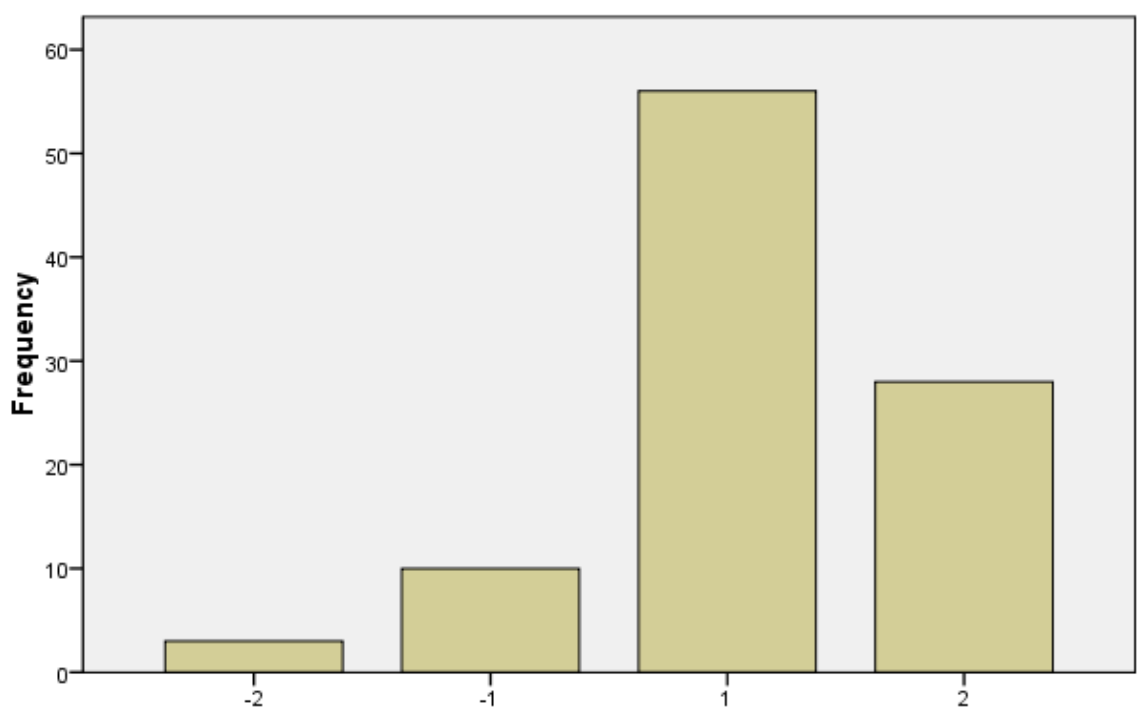

6. Bagian Akhir (Final Section) [Ketersediaan sistem (EOU08)] 
6. Bagian Akhir (Final Section) [Desain dari antarmuka pengguna (EOU09)]

\begin{tabular}{|c|c|c|c|c|c|}
\hline \multirow{3}{*}{ Valid } & & Frequency & Percent & Valid Percent & Cumulative Percent \\
\cline { 2 - 6 } & -2 & 4 & 4.0 & 4.1 & 4.1 \\
\cline { 2 - 6 } & -1 & 13 & 13.0 & 13.4 & 17.5 \\
\cline { 2 - 6 } & 1 & 51 & 51.0 & 52.6 & 70.1 \\
\cline { 2 - 6 } & 2 & 29 & 29.0 & 29.9 & 100.0 \\
\hline & Total & 97 & 97.0 & 100.0 & \\
\hline Missing & System & 3 & 3.0 & & \\
\hline \multicolumn{2}{|c|}{ Total } & 100 & 100.0 & & \\
\hline
\end{tabular}

\section{Bagian Akhir (Final Section) [Desain dari antarmuka pengguna (EOU09)]}

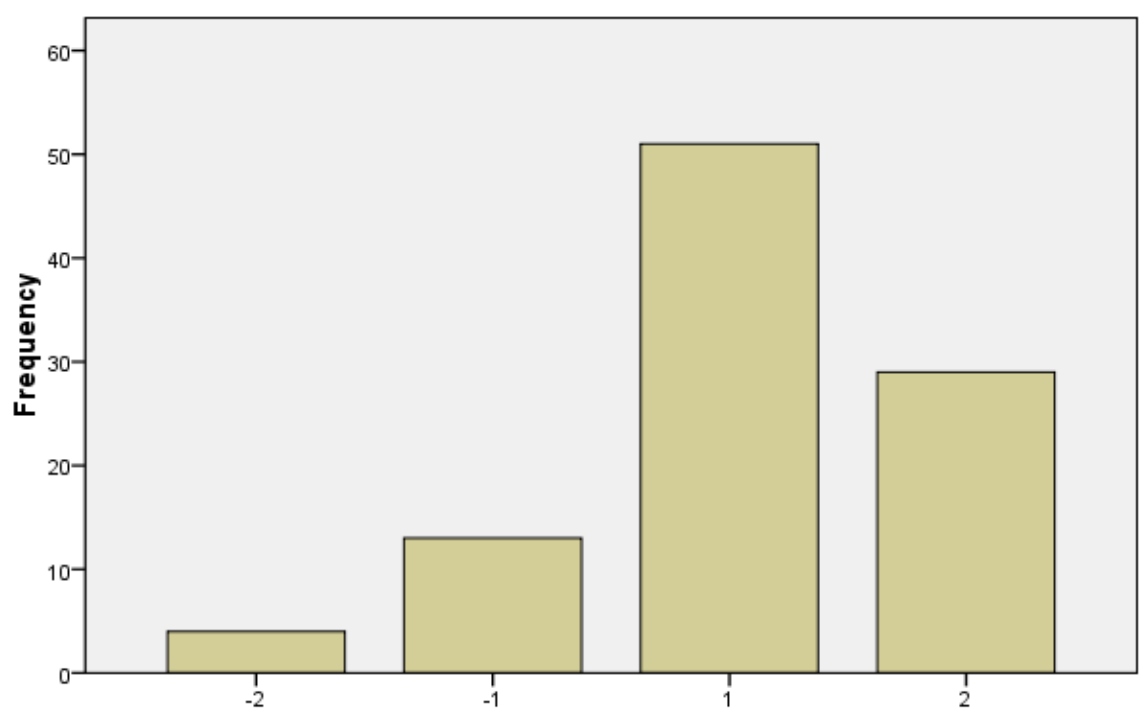

6. Bagian Akhir (Final Section) [Desain dari antarmuka pengguna (EOU09)] 
6. Bagian Akhir (Final Section) [Meningkatkan produktivitas dengan menghemat waktu (USEF13)]

\begin{tabular}{|c|c|c|c|c|c|}
\hline & & Frequency & Percent & Valid Percent & Cumulative Percent \\
\hline Valid & -2 & 3 & 3.0 & 3.1 & 3.1 \\
\cline { 2 - 6 } & -1 & 11 & 11.0 & 11.3 & 14.4 \\
\cline { 2 - 6 } & 0 & 1 & 1.0 & 1.0 & 15.5 \\
\cline { 2 - 6 } & 1 & 54 & 54.0 & 55.7 & 71.1 \\
\cline { 2 - 6 } & 2 & 28 & 28.0 & 28.9 & 100.0 \\
\cline { 2 - 6 } & Total & 97 & 97.0 & 100.0 & \\
\hline Missing & System & 3 & 3.0 & & \\
\hline \multicolumn{7}{|l}{ Total } & 100 & 100.0 & & \\
\hline
\end{tabular}

6. Bagian Akhir (Final Section) [Meningkatkan produktivitas dengan menghemat waktu (USEF13)]

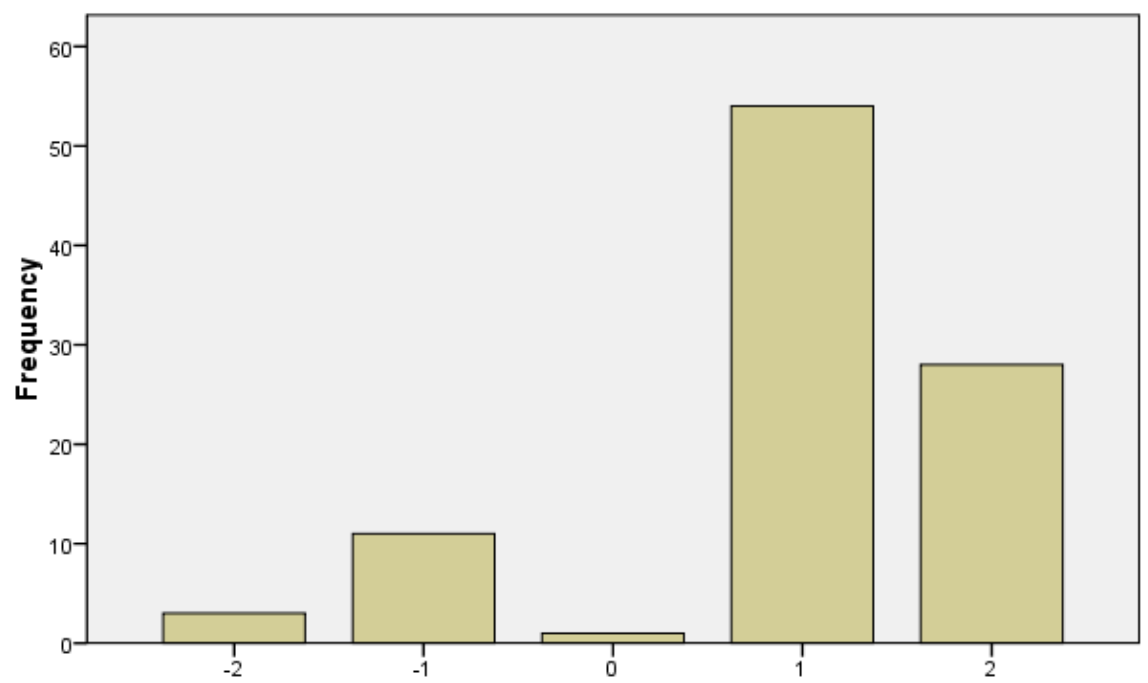

6. Bagian Akhir (Final Section) [Meningkatkan produktivitas dengan menghemat waktu (USEF13)] 
6. Bagian Akhir (Final Section) [Interaksi (USEF14)]

\begin{tabular}{|c|c|c|c|c|c|}
\hline \multirow{3}{*}{ Valid } & & Frequency & Percent & Valid Percent & Cumulative Percent \\
\cline { 2 - 6 } & -2 & 4 & 4.0 & 4.1 & 4.1 \\
\cline { 2 - 6 } & -1 & 17 & 17.0 & 17.5 & 21.6 \\
\cline { 2 - 6 } & 1 & 49 & 49.0 & 50.5 & 72.2 \\
\cline { 2 - 6 } & 2 & 27 & 27.0 & 27.8 & 100.0 \\
\hline & Total & 97 & 97.0 & 100.0 & \\
\hline Missing & System & 3 & 3.0 & & \\
\hline \multicolumn{2}{|c|}{ Total } & 100 & 100.0 & & \\
\hline
\end{tabular}

\section{Bagian Akhir (Final Section) [Interaksi (USEF14)]}

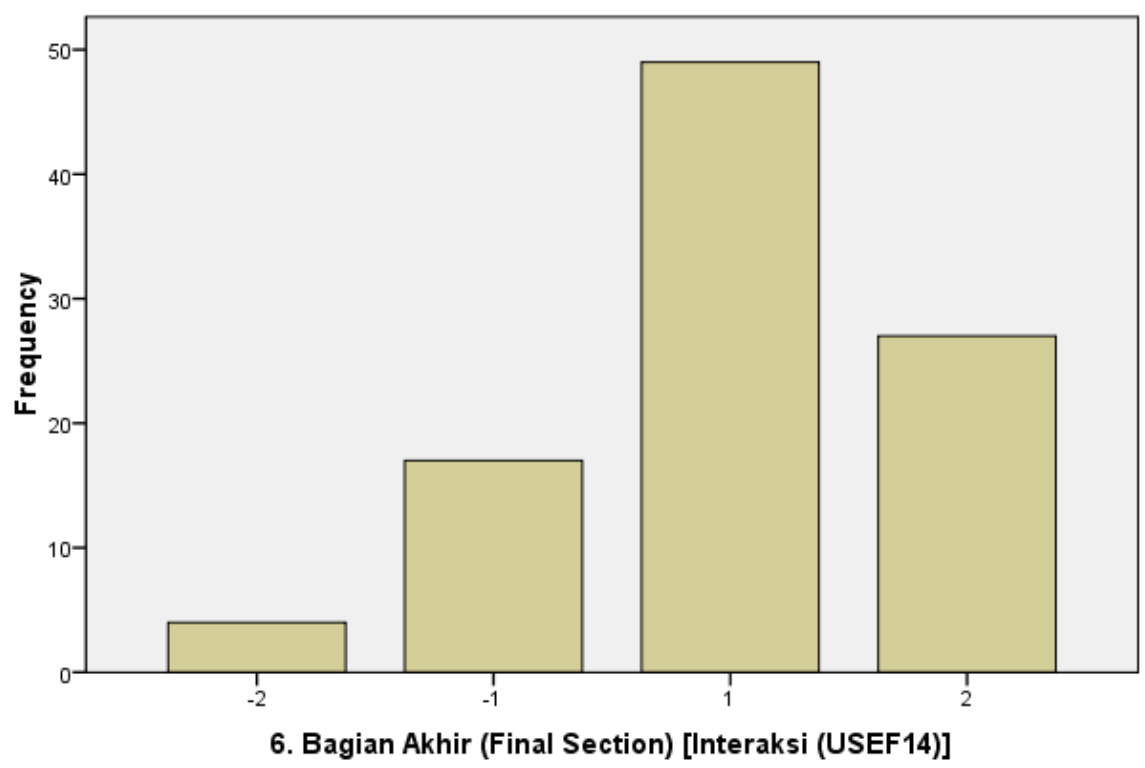


6. Bagian Akhir (Final Section) [Fungsi-fungsi personalisasi (USEF15)]

\begin{tabular}{|c|c|c|c|c|c|}
\hline \multirow{3}{*}{ Valid } & & Frequency & Percent & Valid Percent & Cumulative Percent \\
\cline { 2 - 6 } & -2 & 3 & 3.0 & 3.1 & 3.1 \\
\cline { 2 - 6 } & -1 & 36 & 36.0 & 37.1 & 40.2 \\
\cline { 2 - 6 } & 1 & 34 & 34.0 & 35.1 & 75.3 \\
\cline { 2 - 6 } & 2 & 24 & 24.0 & 24.7 & 100.0 \\
\hline Missing & Total & 97 & 97.0 & 100.0 & \\
\hline \multicolumn{6}{|c|}{ System } \\
\hline
\end{tabular}

6. Bagian Akhir (Final Section) [Fungsi-1fungsi personalisasi (USEF15)]

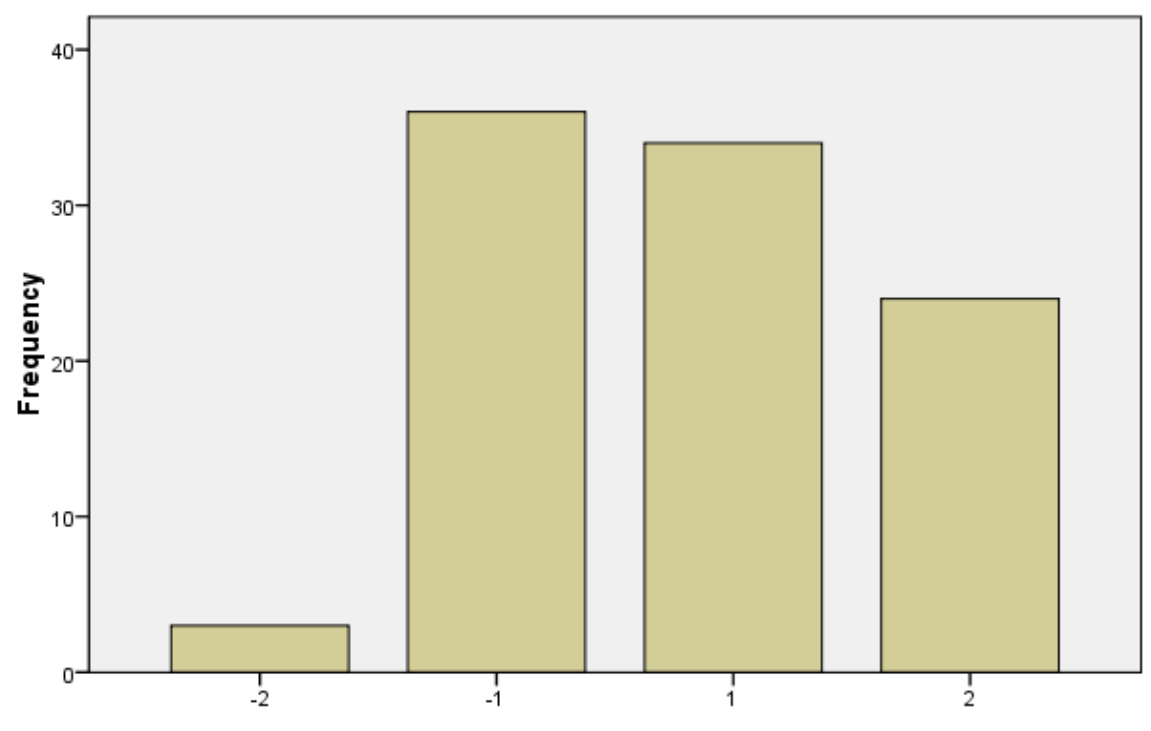

6. Bagian Akhir (Final Section) [Fungsi-1fungsi personalisasi (USEF15)] 
6. Bagian Akhir (Final Section) [Kepercayaan dari rekan bisnis (pemasok) (TRUST1)]

\begin{tabular}{|c|c|c|c|c|c|}
\hline & & Frequency & Percent & Valid Percent & Cumulative Percent \\
\hline \multirow[t]{6}{*}{ Valid } & -2 & 1 & 1.0 & 1.0 & 1.0 \\
\hline & -1 & 13 & 13.0 & 13.4 & 14.4 \\
\hline & 0 & 6 & 6.0 & 6.2 & 20.6 \\
\hline & 1 & 49 & 49.0 & 50.5 & 71.1 \\
\hline & 2 & 28 & 28.0 & 28.9 & 100.0 \\
\hline & Total & 97 & 97.0 & 100.0 & \\
\hline Missing & System & 3 & 3.0 & & \\
\hline \multicolumn{2}{|c|}{ Total } & 100 & 100.0 & & \\
\hline
\end{tabular}

\section{Bagian Akhir (Final Section) [Kepercayaan dari rekan bisnis (pemasok) (TRUST1)]}

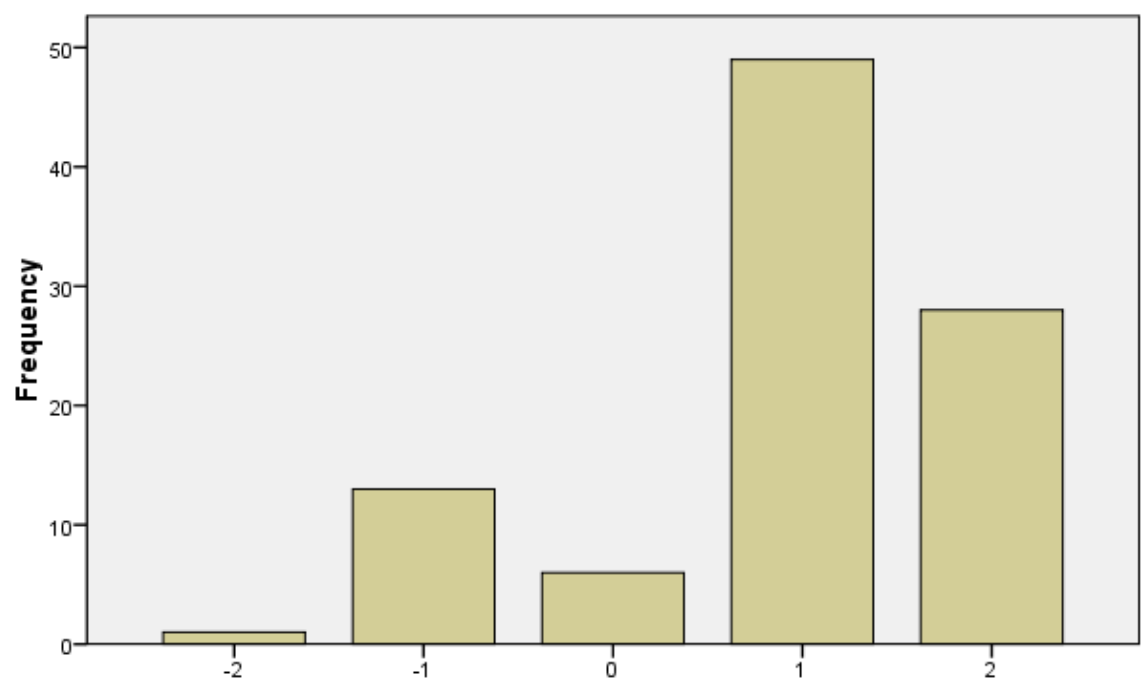

6. Bagian Akhir (Final Section) [Kepercayaan dari rekan bisnis (pemasok) (TRUST1)] 
6. Bagian Akhir (Final Section) [Hal yang dapat dipercaya dari situs web dan situasi legal (TRUST2)]

\begin{tabular}{|c|c|c|c|c|c|}
\hline & & Frequency & Percent & Valid Percent & Cumulative Percent \\
\hline \multirow[t]{5}{*}{ Valid } & -2 & 4 & 4.0 & 4.1 & 4.1 \\
\hline & -1 & 11 & 11.0 & 11.3 & 15.5 \\
\hline & 1 & 53 & 53.0 & 54.6 & 70.1 \\
\hline & 2 & 29 & 29.0 & 29.9 & 100.0 \\
\hline & Total & 97 & 97.0 & 100.0 & \\
\hline Missing & System & 3 & 3.0 & & \\
\hline \multicolumn{2}{|c|}{ Total } & 100 & 100.0 & & \\
\hline
\end{tabular}

6. Bagian Akhir (Final Section) [Hal yang dapat dipercaya dari situs web dan situasi legal (TRUST2)]

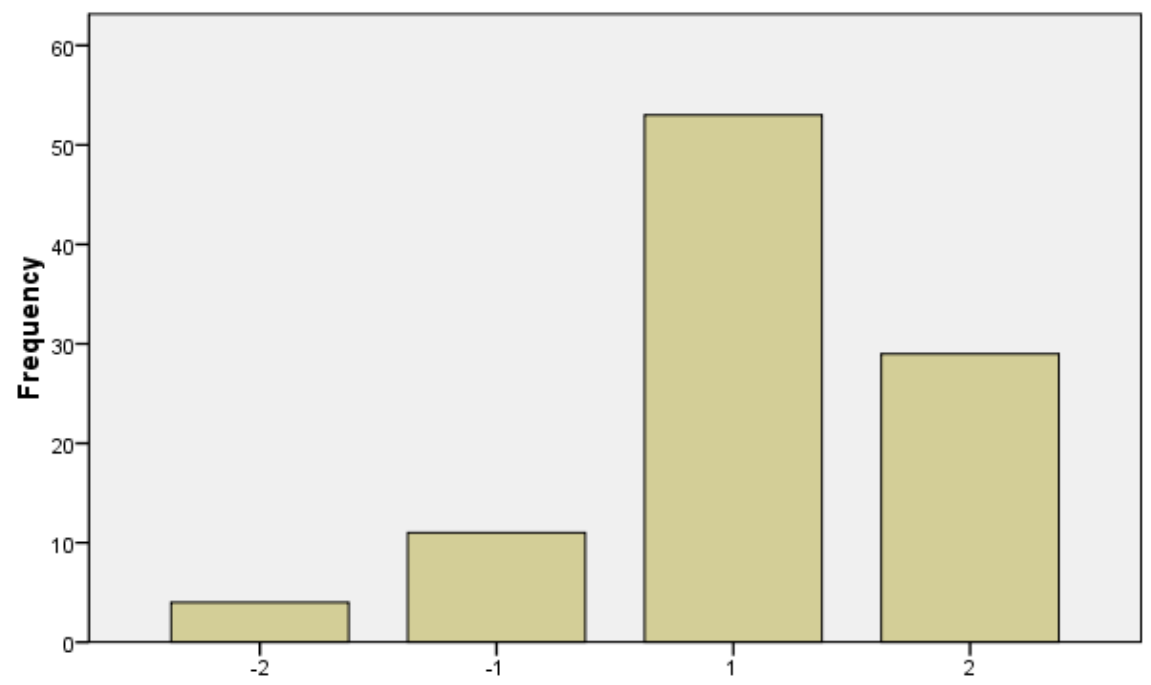

6. Bagian Akhir (Final Section) [Hal yang dapat dipercaya dari situs web dan situasi legal (TRUST2)] 
Lampiran 7 Hasil Evaluasi Situs Web (Lampiran 3 sebagai formulir isian online untuk evaluasi situs web)

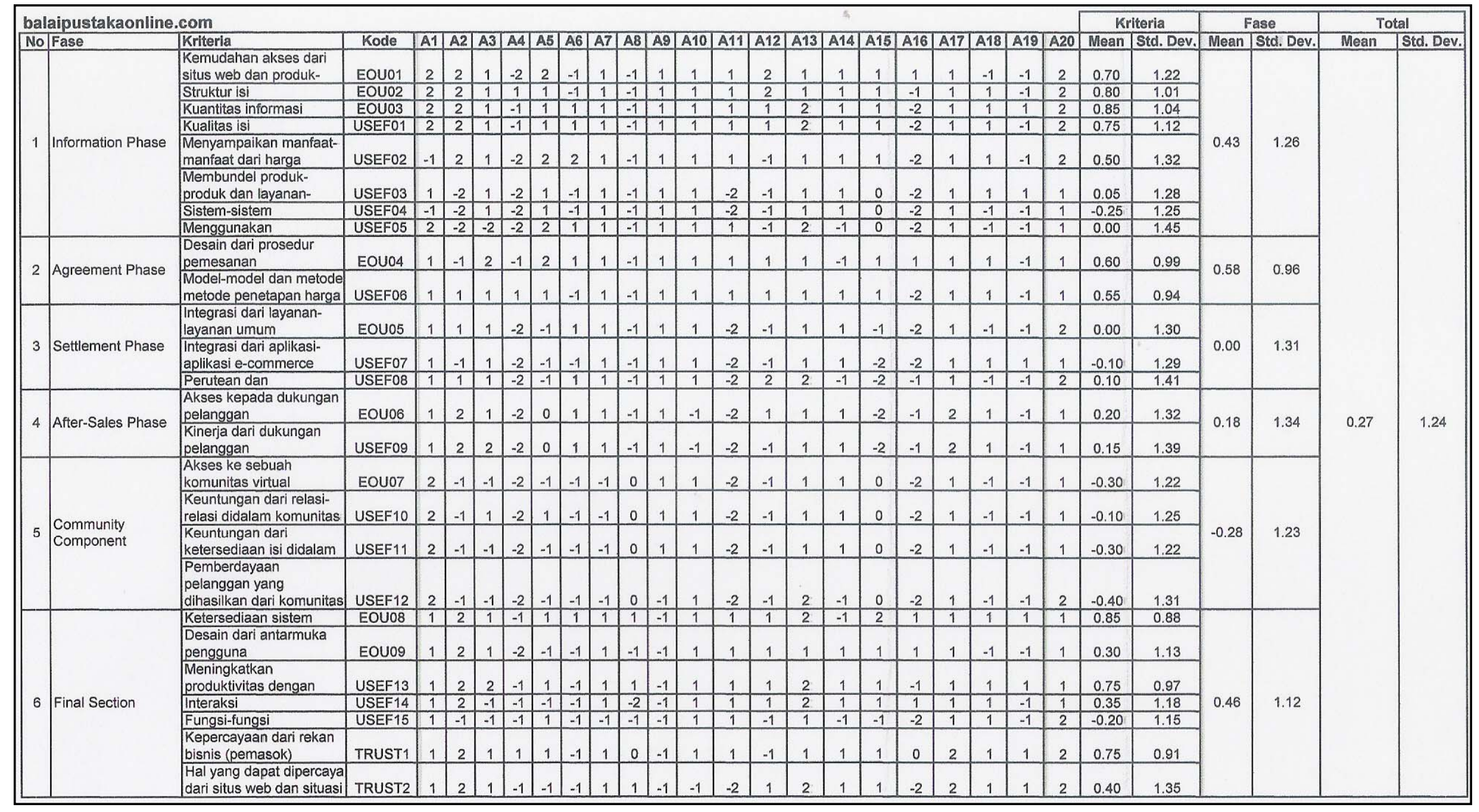

Universitas Indonesia 


\begin{tabular}{|c|c|c|c|c|c|c|c|c|c|c|c|c|c|c|c|c|c|c|c|c|c|c|c|c|c|c|c|c|}
\hline \multicolumn{23}{|c|}{ erlangga.co.id } & \multicolumn{2}{|c|}{ Kriteria } & \multicolumn{2}{|c|}{ Fase } & \multicolumn{2}{|c|}{ Total } \\
\hline No & Fase & Kriteria & Kode & A1 & A2 & A3 & A4 & A5 & A6 & A7 & A8 & A9 & A10 & A11 & A12 & A13 & A14 & A15 & A16 & A17 & A18 & A19 & Mean & Std. Dev. & Mean & Std. Dev. & Mean & Std. Dev. \\
\hline \multirow{8}{*}{1} & \multirow{8}{*}{ Information Phase } & $\begin{array}{l}\text { Kemudahan akses dari situs } \\
\text { web dan produk-produknya }\end{array}$ & EOU01 & 2 & 2 & 1 & 1 & 1 & 2 & 1 & 1 & 2 & 1 & 1 & 1 & 1 & 1 & 2 & 1 & 2 & 2 & 1 & 1.37 & 0.50 & \multirow{8}{*}{0.88} & \multirow{8}{*}{0.99} & \multirow{26}{*}{0.65} & \multirow{26}{*}{1.12} \\
\hline & & Struktur isi & EOU02 & 2 & 2 & 1 & 1 & 2 & 2 & 1 & 1 & 2 & 1 & 1 & 1 & 1 & 1 & 1 & 1 & 2 & 1 & 1 & 1.32 & 0.48 & & & & \\
\hline & & Kuantitas informasi & EOUO3 & 2 & 2 & \begin{tabular}{|l|}
2 \\
\end{tabular} & 1 & 1 & 2 & 1 & 1 & 1 & 1 & 2 & 1 & 1 & 1 & 2 & -1 & 2 & 1 & 1 & 1.26 & 0.73 & & & & \\
\hline & & Kualitas isi & USEF01 & 1 & 2 & 1 & 1 & -1 & 1 & -1 & 1 & 1 & 1 & 2 & 1 & 2 & 1 & 2 & -1 & 2 & 1 & 1 & 0.95 & 0.97 & & & & \\
\hline & & $\begin{array}{l}\text { Menyampaikan manfaat- } \\
\text { manfaat dari harga }\end{array}$ & USEF02 & 1 & 2 & 1 & 1 & -1 & -1 & 1 & -1 & 1 & 1 & 2 & 1 & 1 & -1 & 1 & -1 & 1 & 1 & 2 & 0.63 & 1.07 & & & & \\
\hline & & $\begin{array}{l}\text { Membundel produk-produk } \\
\text { dan layanan-layanannya }\end{array}$ & USEF03 & 1 & -1 & 1 & 1 & -1 & 1 & 1 & 1 & 1 & 1 & 1 & -1 & 1 & -1 & -1 & -2 & 1 & 1 & 1 & 0.32 & 1.06 & & & & \\
\hline & & Sistem-sistem rekomendasi & USEF04 & 1 & -1 & 1 & 1 & -2 & -1 & 1 & 1 & 1 & 1 & 1 & -1 & 1 & -1 & -1 & -2 & 2 & 1 & 1 & 0.21 & 1.23 & & & & \\
\hline & & Menggunakan hypermedia & USEF05 & 2 & -1 & -1 & 2 & 1 & 1 & 1 & 1 & 1 & 1 & 2 & -1 & 2 & 1 & 1 & 0 & 2 & 2 & 1 & 0.95 & 1.03 & & & & \\
\hline & & Desain dari prosedur & EOU04 & 2 & 1 & 1 & 1 & 1 & 1 & -1 & 1 & 1 & 1 & 1 & -1 & 1 & 1 & 2 & 1 & 1 & 1 & 1 & 0.89 & 0.74 & \multirow[b]{2}{*}{0.79} & \multirow[b]{2}{*}{0.78} & & \\
\hline 2 & Agreement Phase & $\begin{array}{l}\text { Model-model dan metode- } \\
\text { metode penetapan harga }\end{array}$ & USEF06 & 1 & 1 & 1 & 1 & 1 & 1 & $\mid-1$ & 1 & 1 & 1 & 1 & -1 & 2 & 1 & 1 & 0 & 1 & -1 & 1 & 0.68 & 0.82 & & & & \\
\hline \multirow{3}{*}{3} & \multirow{3}{*}{ Settlement Phase } & $\begin{array}{l}\text { Integrasi dari layanan-layanan } \\
\text { umum }\end{array}$ & EOU05 & 1 & -1 & 1 & 1 & -1 & 1 & 1 & -1 & 1 & 1 & -2 & -2 & 1 & 1 & 1 & -1 & 2 & 1 & 1 & 0.32 & 1.20 & \multirow{3}{*}{0.40} & \multirow{3}{*}{1.24} & & \\
\hline & & $\begin{array}{l}\text { Integrasi dari aplikasi-aplikasi } \\
\text { e-commerce }\end{array}$ & USEF07 & 1 & -1 & 1 & 1 & -1 & 1 & 1 & $\mid-1$ & 1 & 1 & -2 & -2 & 2 & 1 & 1 & -2 & 2 & 1 & 1 & 0.32 & 1.34 & & & & \\
\hline & & \begin{tabular}{|l} 
Perutean dan penelusuran \\
\end{tabular} & USEF08 & 1 & 2 & 1 & 1 & -1 & 1 & 1 & -1 & 1 & 1 & -2 & -2 & 2 & 1 & 1 & 0 & 2 & 1 & 1 & 0.58 & 1.22 & & & & \\
\hline \multirow{2}{*}{4} & After-Sales Phase & Akses kepada dukungan & EOU06 & 1 & 2 & 1 & 1 & -1 & 1 & 1 & 1 & 1 & -1 & -2 & 1 & 1 & 1 & 1 & 1 & 2 & 1 & 1 & 0.74 & 0.99 & \multirow[t]{2}{*}{0.53} & \multirow[t]{2}{*}{1.11} & & \\
\hline & After-Sales Phase & Kinerja dari dukungan & USEF09 & 1 & 2 & 1 & 1 & -1 & 1 & 1 & -1 & 1 & -1 & -2 & -1 & 1 & 1 & 1 & -1 & 2 & 1 & -1 & 0.32 & 1.20 & & & & \\
\hline \multirow{4}{*}{5} & \multirow{4}{*}{$\begin{array}{l}\text { Community } \\
\text { Component }\end{array}$} & Akses ke sebuah komunitas & EOU07 & -2 & 1 & 1 & 1 & -1 & 1 & -1 & 0 & 1 & 1 & -2 & 1 & 1 & -1 & 1 & 1 & 1 & 1 & -1 & 0.21 & 1.13 & & & & \\
\hline & & $\begin{array}{l}\text { Keuntungan dari relasi-relasi } \\
\text { didalam komunitas }\end{array}$ & USEF10 & $\mid-2$ & -1 & 1 & 1 & -1 & 1 & -1 & 0 & 1 & 1 & -2 & -1 & 2 & -1 & 1 & -1 & 2 & 1 & -2 & -0.05 & 1.35 & & & & \\
\hline & & $\begin{array}{l}\text { Keuntungan dari ketersediaan } \\
\text { isi didalam komunitas }\end{array}$ & USEF11 & 1 & 2 & 1 & 1 & $\mid-1$ & 1 & 1 & -1 & 1 & 1 & -2 & -2 & 2 & 1 & 1 & 0 & 2 & 1 & 1 & 0.58 & 1.22 & 0.25 & 1.29 & & \\
\hline & & $\begin{array}{l}\text { Pemberdayaan pelanggan } \\
\text { yang dihasilkan dari komunitas }\end{array}$ & USEF12 & $\mid-2$ & 1 & 1 & 1 & $\mid-1$ & 1 & -1 & 0 & 1 & 1 & -2 & 1 & 2 & 1 & 2 & -2 & 2 & 1 & -2 & 0.26 & 1.45 & & & & \\
\hline & & Ketersediaan sistem & EOU08 & 1 & 2 & 1 & 1 & -2 & 1 & 1 & 1 & 1 & 1 & 1 & 1 & 1 & 1 & 2 & -1 & 2 & 1 & -1 & 0.79 & 1.03 & & & & \\
\hline & & Desain dari antarmuka & EOUO9 & 2 & 2 & 1 & 2 & -2 & 2 & -1 & 1 & 1 & 1 & 1 & 1 & 1 & 1 & 2 & 1 & 2 & 2 & -1 & 1.00 & 1.15 & & & & \\
\hline & & $\begin{array}{l}\text { Meningkatkan produktivitas } \\
\text { dengan menghemat waktu }\end{array}$ & USEF13 & 1 & 2 & 1 & 1 & -2 & 2 & 1 & 1 & 1 & 1 & 1 & -1 & 2 & 1 & 1 & 1 & 2 & 1 & -1 & 0.84 & 1.07 & & & & \\
\hline $\mathrm{I}_{0}$ & Sontin & \begin{tabular}{|l} 
Interaksi \\
\end{tabular} & USEF14 & 1 & 2 & 1 & 1 & -2 & 2 & 1 & -1 & 1 & 1 & 1 & 1 & 2 & 1 & 1 & -1 & 2 & 1 & -1 & 0.74 & 1.15 & 71 & 119 & & \\
\hline 6 & Final Section & Fungsi-fungsi personalisasi & USEF15 & 1 & 2 & 1 & 1 & -1 & 1 & 1 & -1 & 1 & 1 & 1 & -1 & 2 & -1 & 1 & -1 & 2 & -1 & -1 & 0.42 & 1.17 & 0.71 & 1.13 & & \\
\hline & & $\begin{array}{l}\begin{array}{l}\text { Kepercayaan dari rekan bisnis } \\
\text { (pemasok) }\end{array} \\
\end{array}$ & TRUST1 & 1 & 2 & 1 & 1 & -1 & -1 & 1 & 1 & 1 & 1 & -2 & 1 & 1 & 1 & 1 & 0 & 2 & 1 & -1 & 0.58 & 1.07 & & & & \\
\hline & & $\begin{array}{l}\text { Hal yang dapat dipercaya dari } \\
\text { situs web dan situasi legal }\end{array}$ & TRUST2 & 1 & 2 & 1 & 1 & -1 & -1 & 1 & 1 & 1 & 1 & -2 & 1 & 2 & 1 & 2 & -2 & 2 & 1 & -1 & 0.58 & 1.30 & & & & \\
\hline
\end{tabular}




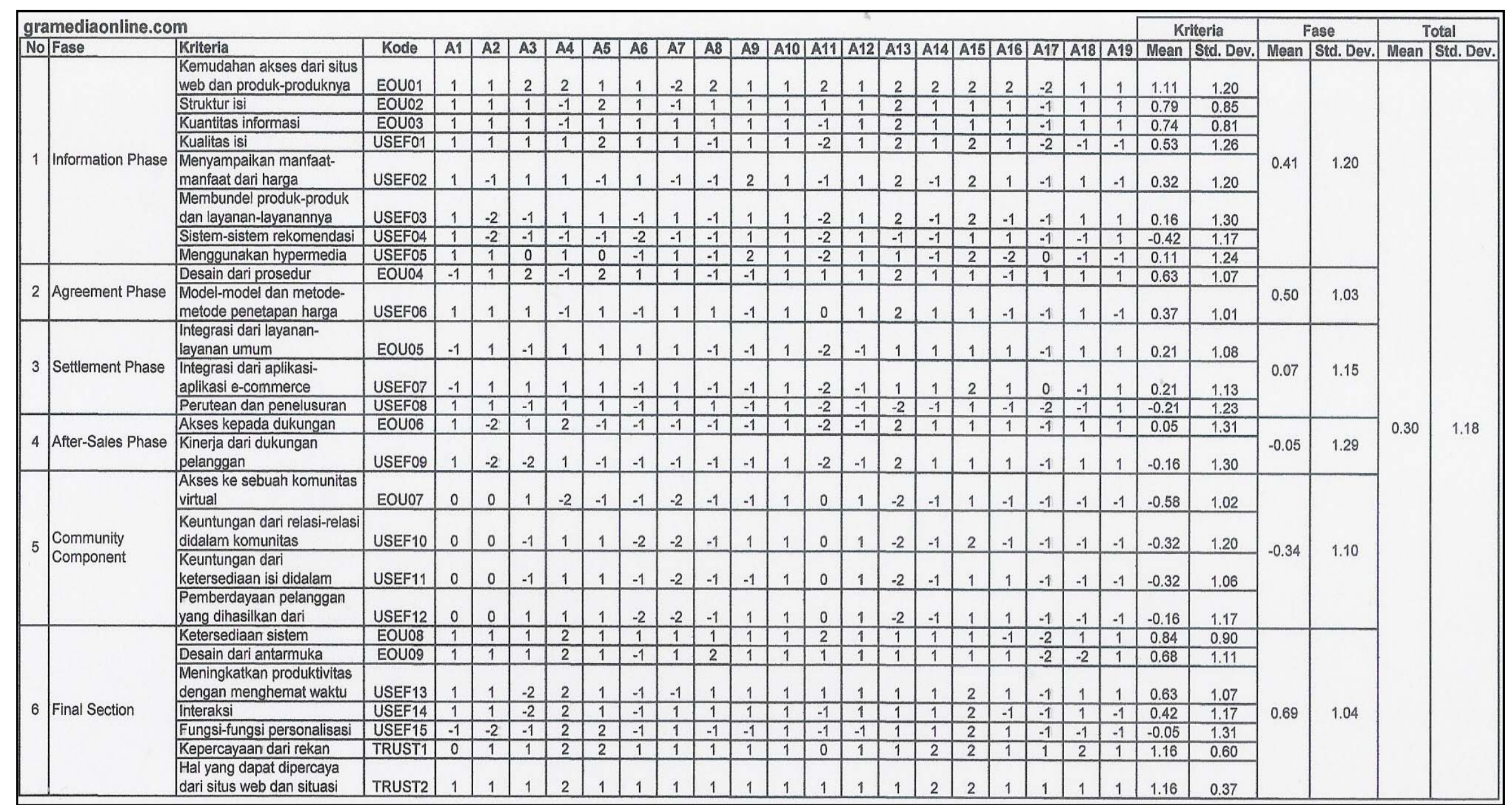

Universitas Indonesia 


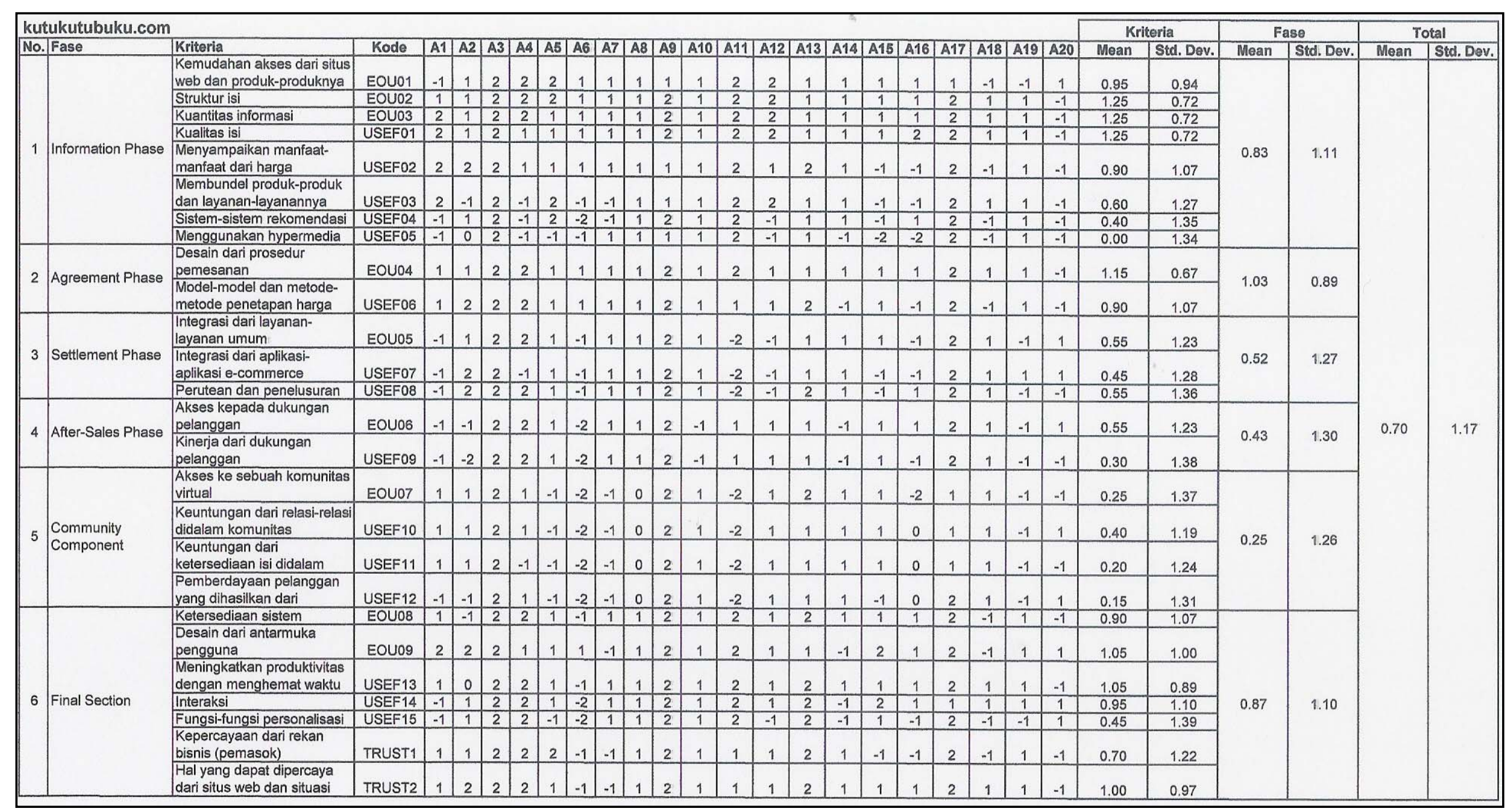

Universitas Indonesia 


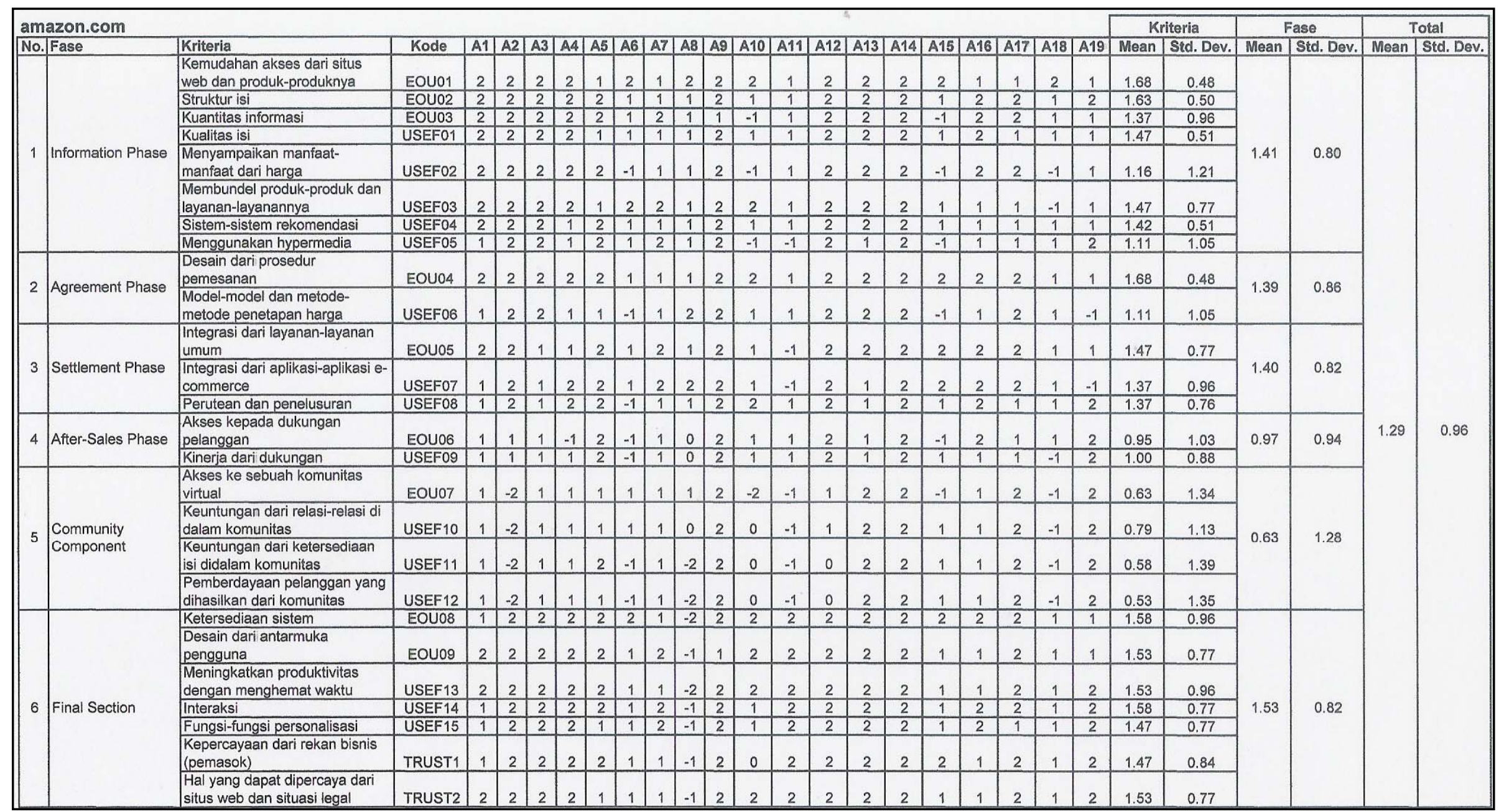

Universitas Indonesia 


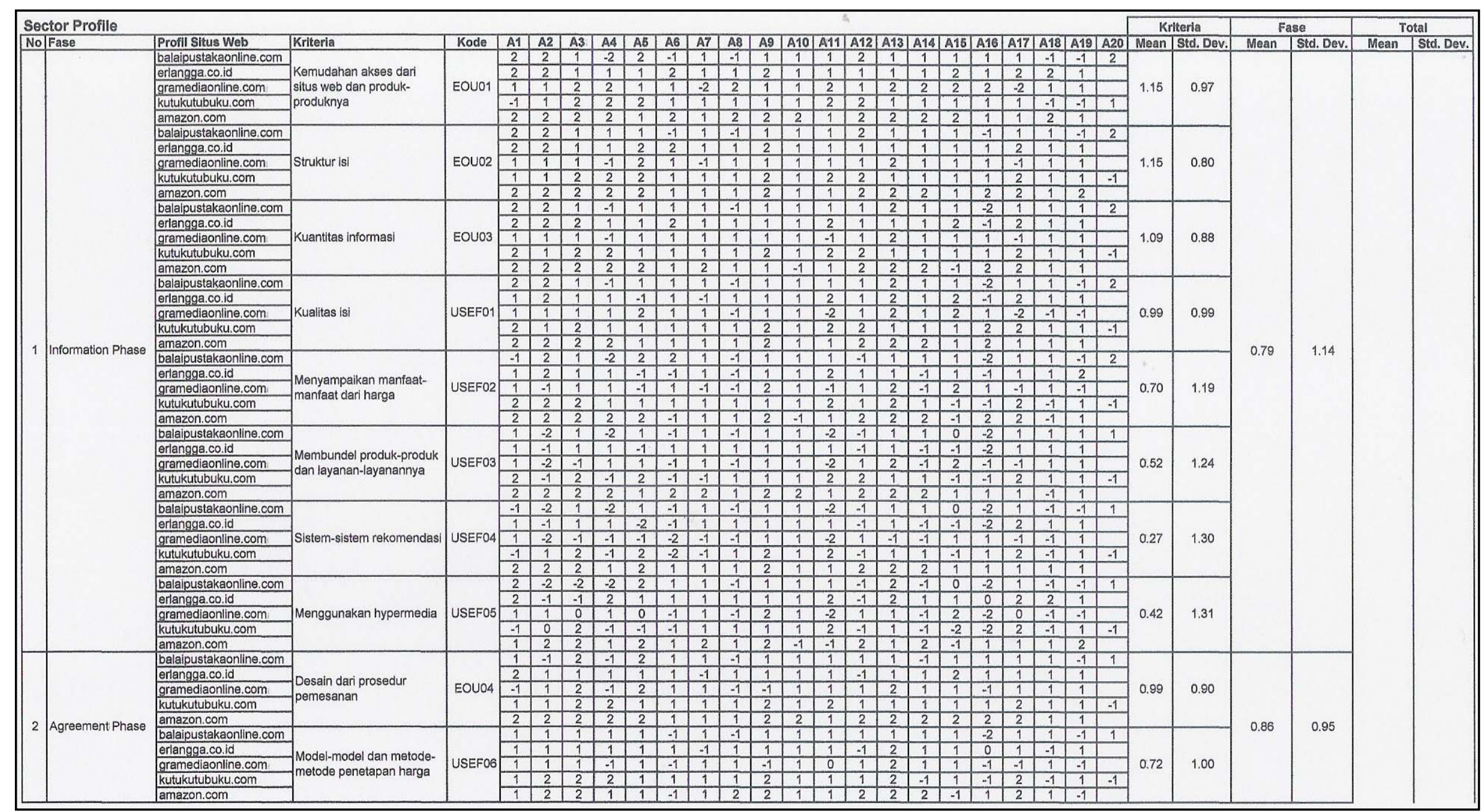

Universitas Indonesia 
Lanjutan Sector Profile

\begin{tabular}{|c|c|c|c|c|c|c|c|c|c|c|c|c|c|c|c|c|c|c|c|c|c|c|c|c|c|c|c|c|c|c|}
\hline \multirow{14}{*}{3} & \multirow{14}{*}{ Settlement Phase } & \begin{tabular}{|l|} 
balaipustakaonline.com \\
erlangga.coid
\end{tabular} & & & \begin{tabular}{|l|}
1 \\
1 \\
\end{tabular} & \begin{tabular}{|c|}
1 \\
-1 \\
\end{tabular} & \begin{tabular}{|l|}
1 \\
1
\end{tabular} & \begin{tabular}{c|}
-2 \\
1
\end{tabular} & \begin{tabular}{|l|}
-1 \\
-1 \\
\end{tabular} & $\frac{1}{1}$ & $\frac{1}{1}$ & \begin{tabular}{|l|}
-1 \\
-1
\end{tabular} & \begin{tabular}{|l|}
1 \\
1
\end{tabular} & \begin{tabular}{|l|}
1 \\
1
\end{tabular} & \begin{tabular}{|l|}
-2 \\
-2 \\
\end{tabular} & $\frac{-1}{-2}$ & $\frac{1}{1}$ & $\frac{1}{1}$ & $\frac{-1}{1}$ & $\frac{-2}{-1}$ & $\frac{1}{2}$ & \begin{tabular}{|c|}
-1 \\
1
\end{tabular} & $\frac{-1}{1}$ & 2 & \multirow{4}{*}{0.51} & \multirow{4}{*}{1.23} & \multirow{13}{*}{0.47} & \multirow{13}{*}{1.27} & \multirow{40}{*}{0.64} & \multirow{40}{*}{1.20} \\
\hline & & 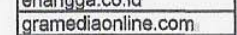 & Integrasi dari layanan- & EOU05 & $\frac{1}{-1}$ & $\frac{-1}{1}$ & -1 & \begin{tabular}{|l|}
1 \\
\end{tabular} & 1 & $\frac{1}{1}$ & 1 & -1 & \begin{tabular}{|c|}
-1 \\
\end{tabular} & $\frac{1}{1}$ & $\frac{-2}{-2}$ & $\frac{-2}{-1}$ & $\frac{1}{1}$ & $\frac{1}{1}$ & $\frac{1}{1}$ & $\frac{-1}{1}$ & $\frac{2}{-1}$ & $\frac{1}{1}$ & $\frac{1}{1}$ & & & & & & & \\
\hline & & kutukutubuku.com & & & \begin{tabular}{|l|}
-1 \\
\end{tabular} & 1 & 2 & 2 & 1 & -1 & 1 & 1 & 2 & 1 & -2 & -1 & 1 & 1 & 1 & -1 & 2 & 1 & -1 & 1 & & & & & & \\
\hline & & amazon.com & & & 2 & 2 & 1 & 1 & 2 & 1 & 2 & 1 & 2 & 1 & -1 & 2 & 2 & 2 & 2 & 2 & 2 & 1 & 1 & & & & & & & \\
\hline & & $\begin{array}{l}\text { balaipustakaonline.com } \\
\end{array}$ & & & 1 & -1 & 1 & -2 & -1 & -1 & 1 & -1 & 1 & 1 & -2 & -1 & 1 & 1 & $\frac{-2}{-2}$ & \begin{tabular}{|c|}
-2 \\
\end{tabular} & 1 & 1 & 1 & 1 & & & & & & \\
\hline & & erlangga.co.id & Hintegrasi dari aplikasi- & & 1 & \begin{tabular}{|l|}
-1 \\
1
\end{tabular} & 1 & 1 & -1 & 1 & 1 & -1 & 1 & 1 & -2 & -2 & 2 & 1 & 1 & -2 & 2 & 1 & 1 & & & & & & & \\
\hline & & gramediaonline.com & aplikasi e-commerce & USEF07 & \begin{tabular}{|l|}
-1 \\
\end{tabular} & 1 & 1 & 1 & 1 & -1 & 1 & -1 & -1 & 1 & -2 & -1 & 1 & 1 & 2 & 1 & 0 & -1 & 1 & & 0.44 & 1.28 & & & & \\
\hline & & \begin{tabular}{|l|} 
kutukutubuku.com \\
\end{tabular} & apikası e-commerce & & \begin{tabular}{|l|}
-1 \\
1
\end{tabular} & 2 & 2 & -1 & 1 & $-\frac{1}{1}$ & 1 & 1 & 2 & 1 & $-\frac{2}{4}$ & -1 & 1 & 1 & \begin{tabular}{|l|}
-1 \\
\end{tabular} & -1 & 2 & 1 & 1 & 1 & & & & & & \\
\hline & & \begin{tabular}{|l} 
amazon.com \\
\end{tabular} & & & \begin{tabular}{|l|}
1 \\
1
\end{tabular} & \begin{tabular}{|l|}
2 \\
1
\end{tabular} & 1 & 2 & 2 & 1 & 2 & 2 & 2 & 1 & -1 & \begin{tabular}{|l|l}
2 \\
2
\end{tabular} & \begin{tabular}{|l}
1 \\
2
\end{tabular} & 2 & 2 & 2 & 2 & 1 & -1 & - & & & & & & \\
\hline & & \begin{tabular}{|l|} 
balaipustakaonline.com \\
\end{tabular} & & & 1 & 1 & 1 & -2 & \begin{tabular}{|c|}
-1 \\
\end{tabular} & 1 & 1 & \begin{tabular}{|l|}
-1 \\
1
\end{tabular} & 1 & 1 & -2 & 2 & 2 & -1 & $\frac{-2}{4}$ & -1 & 1 & -1 & -1 & 2 & & & & & & \\
\hline & & erlangga.co.id & & & \begin{tabular}{|l|l}
1 \\
1
\end{tabular} & 2 & 1 & 1 & -1 & 1 & 1 & -1 & \begin{tabular}{|l|l} 
& \\
\end{tabular} & 1 & -2 & \begin{tabular}{|c|}
-2 \\
\end{tabular} & 2 & 1 & 1 & 0 & 2 & 1 & 1 & - & & & & & & \\
\hline & & gramediaonline.com & Perutean dan penelusuran & USEF08 & \begin{tabular}{|l}
1 \\
1
\end{tabular} & \begin{tabular}{|l|} 
\\
2
\end{tabular} & $-\frac{1}{2}$ & $\frac{1}{2}$ & $\frac{1}{1}$ & -1 & 1 & $\frac{1}{1}$ & 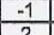 & 1 & -2 & -1 & -2 & \begin{tabular}{|c|}
-1 \\
1
\end{tabular} & 1 & -1 & -2 & -1 & 1 & & 0.47 & 1.31 & & & & \\
\hline & & kutukutubuku.com & & & \begin{tabular}{|c|}
-1 \\
1
\end{tabular} & $\frac{2}{2}$ & $\frac{2}{1}$ & $\frac{2}{2}$ & \begin{tabular}{|l|} 
\\
2
\end{tabular} & -1 & \begin{tabular}{|l}
1 \\
1
\end{tabular} & $\frac{1}{1}$ & \begin{tabular}{|l|}
2 \\
2
\end{tabular} & $\frac{1}{2}$ & $\frac{-2}{1}$ & $\frac{-1}{2}$ & $\frac{2}{1}$ & \begin{tabular}{|l|}
1 \\
\end{tabular} & -1 & \begin{tabular}{|l} 
\\
2
\end{tabular} & 2 & 1 & -1 & -1 & & & & & & \\
\hline & & $\begin{array}{l}\text { amazon.com } \\
\text { balaipustakaonline.com }\end{array}$ & & & $\frac{1}{1}$ & $\frac{2}{2}$ & $\frac{1}{1}$ & \begin{tabular}{|c|}
2 \\
-2
\end{tabular} \mid & $\frac{2}{0}$ & \begin{tabular}{|c|}
-1 \\
1
\end{tabular} & \begin{tabular}{|l|l}
1 \\
1
\end{tabular} & $\frac{1}{-1}$ & \begin{tabular}{|l|}
2 \\
1 \\
\end{tabular} & $\frac{2}{-1}$ & \begin{tabular}{|c|} 
\\
-2 \\
\end{tabular} & $\frac{2}{1}$ & \begin{tabular}{|l|}
1 \\
1
\end{tabular} & $\frac{2}{1}$ & \begin{tabular}{|c|}
1 \\
-2
\end{tabular} & $\frac{2}{-1}$ & \begin{tabular}{|l|}
1 \\
2 \\
\end{tabular} & $\frac{1}{1}$ & $\frac{2}{-1}$ & 1 & & & & & & \\
\hline \multirow{8}{*}{4} & \multirow{8}{*}{ After-Sales Phase } & $\begin{array}{l}\text { Dalapipustakanonine.com } \\
\text { erlangga.co.id }\end{array}$ & & & $\frac{1}{1}$ & \begin{tabular}{|l|}
2 \\
\end{tabular} & 1 & 1 & -1 & $\frac{1}{1}$ & $\frac{1}{1}$ & \begin{tabular}{|c|}
1 \\
\end{tabular} & $\frac{1}{1}$ & -1 & \begin{tabular}{|l|}
-2 \\
-2
\end{tabular} & $\frac{1}{1}$ & $\frac{1}{1}$ & $\frac{1}{1}$ & \begin{tabular}{|c|}
-2 \\
\end{tabular} & $\frac{-1}{1}$ & $\frac{2}{2}$ & \begin{tabular}{|c|}
1 \\
\end{tabular} & \begin{tabular}{|c|}
-1 \\
\end{tabular} & 1 & \multirow{4}{*}{0.49} & \multirow{4}{*}{1.21} & \multirow{8}{*}{0.41} & & & \\
\hline & & gramediaonline.com & Akses kepada dukungan & EOU06 & \begin{tabular}{|l|l}
1 \\
\end{tabular} & -2 & 1 & 2 & -1 & -1 & -1 & -1 & $\frac{1}{-1}$ & 1 & \begin{tabular}{|c|}
-2 \\
-2
\end{tabular} & $\frac{1}{-1}$ & $\frac{1}{2}$ & $\frac{1}{1}$ & \begin{tabular}{|l|}
1 \\
\end{tabular} & $\frac{1}{1}$ & -1 & $\frac{1}{1}$ & $\frac{1}{1}$ & & & & & & & \\
\hline & & kutukutubuku.com & & & \begin{tabular}{|l|}
-1 \\
\end{tabular} & -1 & 2 & 2 & 1 & -2 & 1 & 1 & 2 & -1 & 1 & 1 & 1 & -1 & 1 & 1 & 2 & 1 & -1 & 1 & & & & & & \\
\hline & & amazon.com & & & 1 & 1 & 1 & -1 & 2 & -1 & 1 & 0 & 2 & 1 & 1 & 2 & 1 & 2 & -1 & 2 & 1 & 1 & 2 & & & & & & & \\
\hline & & balaipustakaonline.com & & & 1 & 2 & 2 & -2 & 0 & 1 & 1 & -1 & 1 & -1 & -2 & -1 & 1 & 1 & -2 & -1 & 2 & 1 & -1 & 1 & & & & 1.24 & & \\
\hline & & \begin{tabular}{|l} 
erlangga.co.id \\
\end{tabular} & & & \begin{tabular}{|l|l}
1 \\
\end{tabular} & 2 & 1 & 1 & -1 & 1 & 1 & -1 & 1 & -1 & -2 & -1 & 1 & 1 & 1 & -1 & 2 & 1 & -1 & & & & & & & \\
\hline & & gramediaonline.com & pelanggan & USEF09 & 1 & -2 & -2 & 1 & -1 & -1 & -1 & -1 & -1 & 1 & -2 & -1 & 2 & 1 & 1 & 1 & -1 & 1 & 1 & $T_{1}$ & 0.32 & 1.28 & & & & \\
\hline & & \begin{tabular}{|l} 
kutukutubuku.com \\
amazon.com
\end{tabular} & & & \begin{tabular}{|c|}
-1 \\
1
\end{tabular} & 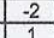 & $\frac{2}{1}$ & $\frac{2}{1}$ & $\frac{1}{2}$ & $\frac{-2}{-1}$ & \begin{tabular}{|l|}
1 \\
1
\end{tabular} & $\frac{1}{0}$ & $\frac{2}{2}$ & \begin{tabular}{|c|}
-1 \\
1
\end{tabular} & $\frac{1}{1}$ & \begin{tabular}{|l|}
1 \\
2
\end{tabular} & $\frac{1}{1}$ & \begin{tabular}{|l|}
$\frac{1}{2}$ \\
\end{tabular} & \begin{tabular}{|l|l}
1 \\
1
\end{tabular} & $\frac{-1}{1}$ & $\frac{2}{1}$ & 1 & $\frac{-1}{2}$ & -1 & & & & & & \\
\hline & & $\begin{array}{l}\text { amazon.com } \\
\text { balaipustakaonline.com } \\
\end{array}$ & & & \begin{tabular}{|l|l|}
2 \\
\end{tabular} & \begin{tabular}{|c|}
-1 \\
\end{tabular} & -1 & -2 & -1 & -1 & \begin{tabular}{|c|}
-1 \\
\end{tabular} & 0 & $\frac{2}{1}$ & $\frac{1}{1}$ & -2 & $\frac{2}{-1}$ & $\frac{1}{1}$ & $\frac{2}{1}$ & 0 & -2 & $\frac{1}{1}$ & \begin{tabular}{|c|}
-1 \\
-1 \\
\end{tabular} & -1 & 1 & & & & & & \\
\hline & & erlangga.co.id & & & \begin{tabular}{|l|}
-2 \\
0
\end{tabular} & 1 & 1 & $\frac{1}{2}$ & -1 & $\frac{1}{1}$ & -1 & 0 & 1 & 1 & -2 & 1 & 1 & -1 & 1 & 1 & 1 & 1 & -1 & & & & & & & \\
\hline & & gramediaonline.com & virtual & EOU07 & 0 & 0 & $\frac{1}{2}$ & $\frac{-2}{1}$ & -1 & -1 & -2 & -1 & -1 & 1 & 0 & \begin{tabular}{|c|}
1 \\
1
\end{tabular} & $\frac{-2}{2}$ & $\frac{-1}{1}$ & 1 & -1 & -1 & -1 & -1 & & 0.04 & 1.27 & & & & \\
\hline & & \begin{tabular}{|l} 
kutukutubuku.com \\
amazon.com
\end{tabular} & & & \begin{tabular}{|l}
1 \\
1 \\
\end{tabular} & \begin{tabular}{|c|} 
\\
-2
\end{tabular} & $\frac{2}{1}$ & $\frac{1}{1}$ & $\frac{-1}{1}$ & $\frac{-2}{1}$ & \begin{tabular}{|c|}
1 \\
1
\end{tabular} & \begin{tabular}{|l|l|} 
\\
1
\end{tabular} & $\frac{2}{2}$ & \begin{tabular}{|c|} 
\\
-2 \\
\end{tabular} & \begin{tabular}{|c|}
-2 \\
-1 \\
\end{tabular} & \begin{tabular}{|c|}
1 \\
1
\end{tabular} & $\frac{2}{2}$ & $\frac{1}{2}$ & $\frac{1}{-1}$ & $\frac{-2}{1}$ & $\frac{1}{2}$ & $\frac{1}{-1}$ & $\frac{-1}{2}$ & -1 & & & & & & \\
\hline & & $\begin{array}{l}\text { amazon.com } \\
\text { balaipustakaonline.com }\end{array}$ & & & $\frac{1}{2}$ & \begin{tabular}{|l|}
-2 \\
-1
\end{tabular} & $\frac{1}{1}$ & $\frac{1}{-2}$ & $\frac{1}{1}$ & $\frac{1}{-1}$ & $\frac{1}{-1}$ & $\frac{1}{0}$ & $\frac{2}{1}$ & $\frac{-2}{1}$ & $\frac{-1}{-2}$ & $\frac{1}{-1}$ & $\frac{2}{1}$ & $\frac{2}{1}$ & $\frac{-1}{0}$ & $\frac{1}{-2}$ & \begin{tabular}{|l}
2 \\
1
\end{tabular} & \begin{tabular}{|c|}
-1 \\
-1
\end{tabular} & $\frac{2}{-1}$ & 1 & & & & & & \\
\hline & & erlangga.co.id & & & -2 & -1 & $\frac{1}{1}$ & $\frac{2}{1}$ & $\frac{1}{-1}$ & 1 & -1 & 0 & $\frac{1}{1}$ & 1 & -2 & $\frac{-1}{-1}$ & $\frac{1}{2}$ & -1 & $\frac{0}{1}$ & -1 & $\frac{1}{2}$ & $+\frac{-1}{1}$ & $\frac{-1}{-2}$ & 1 & & & & & & \\
\hline & & gramediaonline.com & Keuntungan dari relasi- & USEF10 & 0 & 0 & -1 & $\frac{1}{1}$ & 1 & -2 & -2 & \begin{tabular}{|c|} 
\\
\end{tabular} & 1 & 1 & 0 & 1 & $|-2|$ & -1 & $\frac{1}{2}$ & $\frac{-1}{-1}$ & $\mid-1$ & \begin{tabular}{|c|}
-1 \\
-1
\end{tabular} & $\mid-1$ & & 0.14 & 1.27 & & & & \\
\hline & & kutukutubuku.com & Frelasi didalam komunitas. & & & 1 & 2 & 1 & -1 & -2 & -1 & 0 & 2 & 1 & -2 & 1 & 1 & 1 & 1 & 0 & 1 & 1 & -1 & 1 & & & & & & \\
\hline & Community & amazon.com & & & \begin{tabular}{|l|}
1 \\
2
\end{tabular} & -2 & 1 & 1 & 1 & 1 & 1 & 0 & 2 & 0 & -1 & 1 & 2 & 2 & 1 & 1 & 2 & -1 & 2 & & & & & & & \\
\hline & Component & balaipustakaonline.com & & & 2 & -1 & -1 & -2 & -1 & -1 & -1 & 0 & 1 & 1 & -2 & -1 & 1 & 1 & 0 & -2 & 1 & -1 & -1 & 1 & & & 0.10 & 1.28 & & \\
\hline & & erlangga.co.id & Keuntungan dari & & \begin{tabular}{|l}
1 \\
\end{tabular} & 2 & 1 & & -1 & & 1 & -1 & 1 & 1 & -2 & -2 & 2 & 1 & 1 & 0 & 2 & 1 & 1 & & & & & & & \\
\hline & & gramediaonline.com & ketersediaan isi didalam & USEF11 & 0 & 0 & $-\frac{1}{2}$ & 1 & 1 & -1 & -2 & -1 & $-1 \mid$ & 1 & 0 & 1 & -2 & -1 & 1 & 1 & -1 & -1 & -1 & & 0.14 & 1.27 & & & & \\
\hline & & $\begin{array}{l}\text { kutukutubuku.com } \\
\text { amzanon com }\end{array}$ & komunitas & & \begin{tabular}{|l|l}
1 \\
\end{tabular} & 1 & $\frac{2}{1}$ & $\frac{-1}{1}$ & $\frac{-1}{2}$ & $\frac{-2}{-1}$ & $\frac{-1}{1}$ & $\frac{0}{-2}$ & $\frac{2}{2}$ & \begin{tabular}{|l|}
1 \\
0 \\
\end{tabular} & \begin{tabular}{|c|}
-2 \\
-1 \\
\end{tabular} & \begin{tabular}{|c|}
1 \\
0
\end{tabular} & \begin{tabular}{|l|} 
\\
2
\end{tabular} & $\frac{1}{2}$ & \begin{tabular}{|l}
1 \\
1
\end{tabular} & \begin{tabular}{|l}
0 \\
1
\end{tabular} & $\begin{array}{l}1 \\
2\end{array}$ & $\frac{1}{-1}$ & -1 & -1 & & & & & & \\
\hline & & |amazon.com & & & $\frac{1}{2}$ & $\frac{-2}{-1}$ & $\frac{1}{-1}$ & $\frac{1}{-2}$ & $\frac{2}{-1}$ & $\frac{-1}{-1}$ & $\frac{1}{-1}$ & $\frac{-2}{0}$ & $\frac{2}{-1}$ & $\frac{0}{1}$ & $\frac{-1}{-2}$ & $\frac{5}{-1}$ & $\frac{2}{2}$ & $\frac{2}{-1}$ & $\frac{1}{10}$ & $\frac{1}{-2}$ & $\frac{2}{1}$ & $\begin{array}{l}-1 \\
-1\end{array}$ & $\frac{2}{-1}$ & 2 & & & & & & \\
\hline & & erlanguga.coid & yaan pelanggan & & \begin{tabular}{|c|}
-2 \\
\end{tabular} & \begin{tabular}{|c|}
-1 \\
\end{tabular} & \begin{tabular}{|l|}
-1 \\
1
\end{tabular} & $\frac{-2}{1}$ & $\frac{-1}{-1}$ & $\frac{1}{1}$ & $\frac{-1}{-1}$ & 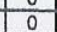 & \begin{tabular}{|c|}
1 \\
\end{tabular} & $\frac{1}{1}$ & $\frac{-2}{-2}$ & \begin{tabular}{|c|}
-1 \\
1
\end{tabular} & $\frac{2}{2}$ & \begin{tabular}{|l|l|}
-1 \\
\end{tabular} & \begin{tabular}{|l}
0 \\
\end{tabular} & $\mid-2$ & \begin{tabular}{|l}
1 \\
\end{tabular} & \begin{tabular}{|l}
-1 \\
1
\end{tabular} & $\frac{-1}{-2}$ & 2 & & & & & & \\
\hline & & gramediaonline.com & yang d & USEF12 & 0 & 0 & 1 & 1 & 1 & -2 & -2 & -1 & 1 & 1 & 0 & 1 & -2 & -1 & 1 & 1 & -1 & -1 & -1 & 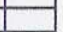 & 0.07 & 1.33 & & & & \\
\hline & & kutukutubuku.com & komunitas & & -1 & & & & -1 & -2 & -1 & 0 & & 1 & -2 & 1 & 1 & 1 & -1 & 0 & 2 & 1 & -1 & 1 & & & & & & \\
\hline & & amazon.com & & & 1 & -2 & - & 1 & 1 & $1-1$ & 1 & -2 & 2 & 0 & \begin{tabular}{|l|} 
\\
\end{tabular} & 0 & 2 & 2 & 11 & 11 & $?$ & $\mid-1$ & 12 & & & & & & & \\
\hline
\end{tabular}


Lanjutan Sector Profile

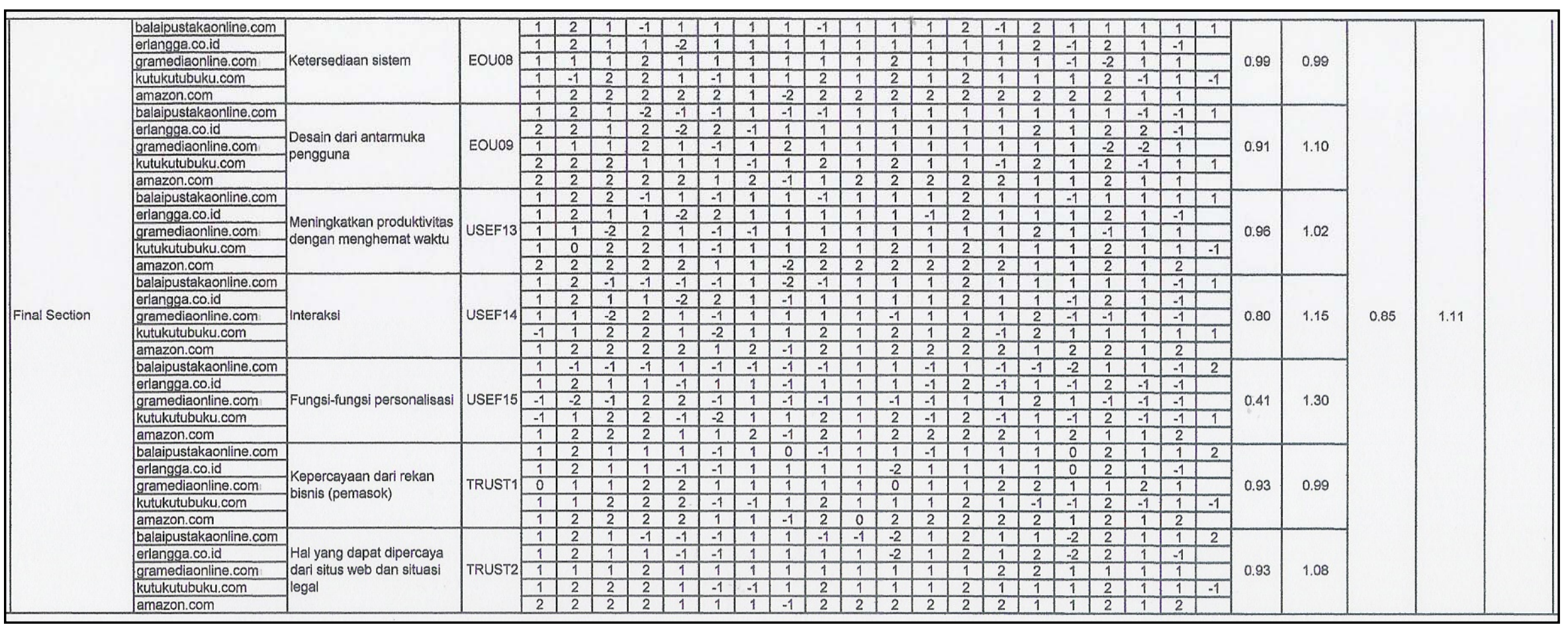


Lampiran 8 Hasil Evaluasi Kriteria (Lampiran 2 sebagai formulir isian online untuk evaluasi kriteria)

\begin{tabular}{|c|c|c|c|c|c|c|c|c|c|c|c|c|c|c|c|c|c|c|c|c|c|c|c|c|c|c|}
\hline \multirow[b]{2}{*}{ No. } & \multirow[b]{2}{*}{ Fase } & \multirow[b]{2}{*}{ Kriteria } & \multirow[b]{2}{*}{ Kode } & \multirow[b]{2}{*}{ A1 } & \multirow[b]{2}{*}{ A2 } & \multirow[b]{2}{*}{$\mathrm{A3}$} & \multirow[b]{2}{*}{ A4 } & \multirow[b]{2}{*}{ A5 } & \multirow[b]{2}{*}{ A6 } & \multirow[b]{2}{*}{ A7 } & \multirow[b]{2}{*}{ A8 } & \multirow[b]{2}{*}{ A9 } & \multirow[b]{2}{*}{ A10 } & \multirow[b]{2}{*}{ A11 } & \multirow[b]{2}{*}{ A12 } & \multirow[b]{2}{*}{$\overline{A 13}$} & \multirow[b]{2}{*}{ A14 } & \multirow[b]{2}{*}{ A15 } & \multirow[b]{2}{*}{ A16 } & \multirow[b]{2}{*}{ A17 } & & & & teria & & ase \\
\hline & & & & & & & & & & & & & & & & & & & & & A18 & A19 & Mean & Std. Dev. & Mean & Std. Dev \\
\hline & & Kemudahan akses dari situs web dan produk- & FOU日1 & 1 & 1 & 2 & 2 & 2 & 2 & $=$ & 2 & 2 & 2 & 2 & 2 & 2 & $?$ & 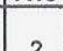 & 1 & 2 & 2 & 1 & 170 & 040 & & \\
\hline & & Struktur isi & EOU02 & 2 & $\frac{1}{1}$ & $\frac{\pi}{2}$ & 2 & 2 & $\frac{5}{2}$ & $\frac{2}{2}$ & $\frac{4}{2}$ & \begin{tabular}{|c|}
2 \\
\end{tabular} & $\frac{2}{1}$ & $\frac{2}{2}$ & $\frac{2}{2}$ & $\frac{2}{1}$ & $\frac{5}{2}$ & $\frac{5}{2}$ & 1 & $\frac{2}{1}$ & $\frac{2}{1}$ & $\frac{1}{2}$ & $\frac{1.19}{1.68}$ & 0.42 & & \\
\hline & & Kuantitas informasi & EOUO3 & $\frac{2}{2}$ & $\frac{1}{1}$ & $\frac{2}{1}$ & $\frac{2}{2}$ & $\frac{2}{2}$ & $\frac{\pi}{2}$ & $\frac{6}{2}$ & $\frac{2}{2}$ & 2 & $\frac{1}{1}$ & $\frac{2}{2}$ & $\frac{2}{2}$ & $\frac{1}{2}$ & $\frac{2}{2}$ & $\frac{2}{2}$ & $\frac{1}{2}$ & $\frac{1}{2}$ & $\frac{1}{2}$ & $\frac{2}{2}$ & 1.84 & 0.37 & & \\
\hline 1 & Information Phase & Kualitas isi & USEF01 & 2 & 1 & 2 & 2 & 2 & 2 & 2 & 2 & 2 & 1 & 2 & 2 & 2 & 2 & 2 & 1 & 2 & $\frac{5}{2}$ & 2 & 1.84 & 0.37 & 1.47 & 0.80 \\
\hline & & Menyampaikan manfaat-manfaat dari harga & USEF02 & $\frac{4}{2}$ & $\frac{1}{-1}$ & $\frac{4}{2}$ & \begin{tabular}{|l|l|l|l} 
\\
\end{tabular} & $\frac{2}{2}$ & $\frac{4}{2}$ & $\frac{2}{2}$ & $\frac{2}{1}$ & $\frac{2}{1}$ & $\frac{1}{2}$ & $\frac{2}{2}$ & $\frac{2}{2}$ & $\frac{2}{1}$ & $\frac{2}{1}$ & $\frac{2}{-1}$ & $\frac{1}{1}$ & $\frac{2}{1}$ & $\frac{2}{2}$ & $\frac{2}{2}$ & $\frac{1.04}{1.32}$ & 0.95 & & \\
\hline & & Membundel produk-produk dan layanan- & USEFO3 & 1 & -1 & 2 & 2 & 2 & 1 & 1 & 2 & 2 & 1 & 2 & 1 & 2 & 1 & 1 & 1 & -1 & 2 & $\frac{\pi}{1}$ & 1.21 & 0.92 & & \\
\hline & & Sistem-sistem rekomendasi & USEF04 & 1 & -1 & 2 & 2 & 2 & 1 & 2 & 2 & 2 & 1 & 2 & 1 & 1 & 1 & 1 & 1 & 1 & 2 & 0 & 1.26 & 0.81 & & \\
\hline & & Mengqunakan hypermedia & USEF05 & 1 & -1 & 2 & 2 & 2 & 1 & -1 & -1 & 2 & 1 & 2 & 1 & 2 & -1 & -1 & 1 & 1 & $\frac{\pi}{1}$ & 1 & 0.79 & 1.18 & & \\
\hline & & Desain dari prosedur pemesanan & EOU04 & 2 & 1 & 2 & 1 & 2 & 2 & 2 & 1 & 2 & 2 & 1 & 2 & 2 & 2 & 2 & 1 & $\frac{1}{1}$ & 2 & 1 & 1.63 & 0.50 & & \\
\hline 2 & Agreement Phase & Model-model dan metode-metode penetapan & HSEEOG & 2 & 1 & 1 & 1 & , & 2 & $=$ & 1 & 2 & 2 & 2 & 1 & 2 & 1 & 1 & 1 & 1 & 2 & 1 & 120 & 003 & 1.45 & 0.76 \\
\hline & & Integrasi dari layanan-layanan umum & EOU05 & $\frac{2}{1}$ & $\frac{1}{1}$ & 2 & $\frac{1}{2}$ & 2 & $\frac{2}{1}$ & 2 & 1 & 2 & $\frac{2}{1}$ & 2 & $\frac{1}{1}$ & $\frac{2}{1}$ & $\frac{1}{1}$ & $\frac{-1}{1}$ & $\frac{1}{1}$ & $\frac{1}{1}$ & $\frac{2}{2}$ & $\frac{1}{1}$ & 1.37 & 0.50 & & \\
\hline 3 & Settlement Phase & Integrasi dari aplikasi-aplikasi e-commerce & USEF07 & 1 & $\frac{1}{1}$ & $\frac{4}{2}$ & $\frac{2}{1}$ & $\frac{2}{2}$ & $\frac{1}{1}$ & $\frac{6}{2}$ & 1 & $\frac{2}{2}$ & $\frac{1}{1}$ & $\frac{2}{2}$ & $\frac{1}{1}$ & $\frac{1}{2}$ & $\frac{1}{1}$ & $\frac{1}{-1}$ & $\frac{1}{2}$ & $\frac{1}{1}$ & $\frac{2}{2}$ & $\frac{1}{1}$ & $\frac{1.01}{1.32}$ & 0.75 & 1.35 & 0.69 \\
\hline & & Perutean dan penelusuran & USEF08 & 2 & 0 & 2 & 1 & 1 & 2 & 2 & 1 & 2 & 2 & 2 & 1 & 2 & 1 & 2 & 1 & $\frac{1}{1}$ & 2 & -1 & 1.37 & 0.83 & & \\
\hline 4 & After-Salec Phace & Akses kepada dukungan pelanggan & EOU06 & 2 & -1 & $\frac{\pi}{2}$ & $\frac{1}{2}$ & 2 & 1 & 1 & 1 & 1 & 1 & 2 & 1 & 1 & $\frac{1}{1}$ & 2 & 2 & 2 & 2 & 2 & 1.42 & 0.77 & & \\
\hline 4 & After-Sales Phase & Kinerja dari dukungan pelanggan & USEF09 & 2 & -1 & 2 & $\frac{\pi}{1}$ & 2 & $\frac{1}{1}$ & $\frac{1}{2}$ & 1 & 1 & 1 & 2 & 2 & $\frac{1}{1}$ & $\frac{1}{1}$ & $\frac{2}{2}$ & 2 & $\frac{2}{2}$ & $\frac{2}{2}$ & $\frac{2}{1}$ & 1.42 & 0.77 & 1.42 & 0.76 \\
\hline & & Akses ke sebuah komunitas virtual & EOU07 & 1 & 0 & 2 & 2 & 0 & -1 & 1 & 1 & 1 & 1 & 1 & $\frac{1}{1}$ & 1 & -1 & 1 & -1 & 2 & 1 & 2 & 0.79 & 0.98 & & \\
\hline & & Keuntungan dari relasi-relasi didalam & & & & & & & & & & & & & & & & & & & & & & & & \\
\hline & Community & komunitas & USEF10 & 2 & 0 & 2 & 2 & 1 & -1 & 1 & 1 & 1 & 2 & 1 & 1 & 1 & -1 & 1 & -1 & -2 & 1 & 2 & 0.74 & 1.19 & & \\
\hline 5 & Component & Keuntungan dari ketersediaan isi didalam & USEF11 & $\frac{4}{2}$ & 0 & $\frac{2}{2}$ & $\frac{2}{2}$ & $\frac{1}{1}$ & $\frac{-1}{-1}$ & $\frac{1}{2}$ & 1 & $\frac{1}{1}$ & $\frac{2}{2}$ & $\frac{1}{2}$ & $\frac{1}{1}$ & $\frac{1}{1}$ & $\frac{-1}{-1}$ & $\frac{1}{1}$ & $\frac{-1}{-1}$ & $\frac{-2}{-2}$ & $\frac{1}{1}$ & $\frac{2}{1}$ & $\frac{0.14}{0.79}$ & $\frac{1.19}{1.23}$ & 0.74 & 1.16 \\
\hline & & $\begin{array}{l}\text { Pemberdayaan pelanggan yang dihasilkan } \\
\text { dari komunitas }\end{array}$ & USEF12 & 2 & 0 & 2 & 2 & 0 & -1 & 2 & 1 & 1 & 1 & 2 & 1 & 1 & -1 & 2 & -1 & -2 & -1 & 1 & 0.63 & 1.30 & & \\
\hline & & Ketersediaan sistem & EOU08 & $\frac{2}{2}$ & $\frac{1}{1}$ & $\frac{6}{2}$ & $\frac{6}{1}$ & $\frac{5}{2}$ & $\frac{1}{1}$ & $\frac{2}{1}$ & $\frac{1}{1}$ & $\frac{1}{2}$ & $\frac{1}{2}$ & $\frac{2}{2}$ & $\frac{1}{2}$ & $\frac{1}{2}$ & $\frac{-1}{2}$ & $\frac{2}{2}$ & $\frac{-1}{1}$ & $\frac{-2}{1}$ & $\frac{-1}{2}$ & $\frac{1}{1}$ & 1.58 & 0.51 & & \\
\hline & & Desain dari antarmuka pengguna & EOU09 & 2 & 1 & 2 & 2 & 2 & 1 & 1 & 1 & 2 & 1 & 2 & 2 & 2 & 1 & 2 & 1 & $\frac{1}{1}$ & $\frac{\pi}{2}$ & $\frac{1}{1}$ & 1.53 & 0.51 & & \\
\hline & & Meningkatkan produktivitas dengan & & & 1 & . & 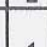 & 0 & 2 & 0 & I & ? & 1 & 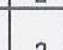 & 1 & 0 & 1 & 2 & 0 & 0 & 0 & 1 & & & & \\
\hline 6 & Final Section & menghemat waktu & $\frac{\text { USEF } 13}{\text { USEF14 }}$ & $\frac{2}{1}$ & -1 & $\frac{2}{2}$ & $\frac{1}{1}$ & $\frac{2}{2}$ & $\frac{2}{2}$ & $\frac{2}{1}$ & $\frac{1}{1}$ & $\frac{2}{2}$ & $\frac{1}{1}$ & $\frac{2}{2}$ & $\frac{1}{2}$ & $\frac{2}{2}$ & $\frac{1}{1}$ & $\frac{2}{2}$ & $\frac{2}{1}$ & $\frac{2}{1}$ & $\frac{2}{2}$ & $\frac{1}{2}$ & $\frac{1.53}{1.10}$ & 0.77 & 147 & 076 \\
\hline & & Fungsi-fungsi personalisasi & USEF15 & $\frac{1}{1}$ & -1 & $\frac{2}{1}$ & $\frac{1}{1}$ & $\frac{2}{2}$ & $\frac{2}{1}$ & $\frac{1}{1}$ & 1 & $\frac{4}{2}$ & $\frac{1}{2}$ & $\frac{4}{2}$ & $\frac{2}{1}$ & $\frac{2}{1}$ & $\frac{1}{-1}$ & $\frac{2}{2}$ & -1 & $\frac{1}{-1}$ & $\frac{2}{2}$ & $\frac{2}{1}$ & $\frac{1.46}{0.89}$ & $\frac{.21}{1.10}$ & & \\
\hline & & Kepercayaan dari rekan bisnis (pemasok) & TRUST1 & 2 & 0 & 2 & 2 & 2 & 2 & 2 & 1 & 2 & 2 & 2 & 1 & 2 & -1 & 2 & 2 & 1 & 2 & 2 & 1.58 & 0.84 & & \\
\hline & & Hal yang dapat dipercaya dari situs web dan & TRUST) & 2 & 1 & 2 & 2 & 2 & 2 & $?$ & 1 & $?$ & 2 & $2+2$ & 1 & 2 & 2 & $?$ & $?$ & 1 & $?$ & $?$ & 170 & 012 & & \\
\hline
\end{tabular}




\section{Lampiran 9 Hasil Kalkulasi Evaluasi Situs Web Berdasarkan Peringkat Penting}

(Hasil kalkulasi didasarkan Persamaan (2,1)-(2,17) dapat dilihat pada BAB 2 halaman 31-36)

\begin{tabular}{|c|c|c|c|c|c|c|c|c|c|c|c|c|c|c|c|c|c|c|c|c|}
\hline \multicolumn{21}{|c|}{ balaipustakaonline.com } \\
\hline No. & Category $\left(K_{k}\right)$ & Criteria $\left(X_{i}\right)$ & Code & $\left|\begin{array}{l}\text { Importance: } W_{i} \\
\text { (Range -2l+2) }\end{array}\right|$ & $\mid \begin{array}{l}\text { Importance: } \mathrm{Wg}_{\mathrm{I}} \\
\text { (Range 0-1) }\end{array}$ & $\begin{array}{l}\text { Evaluation: Average }\left(r_{1}\right) \\
(\text { Range }-2 /+2)\end{array}$ & $\begin{array}{l}\text { Welghted Value } R_{i,} \\
R_{i}=W g_{i} \text { "Average }\left(r_{i}\right)\end{array}$ & $K_{k}\left(\Sigma R_{1}\right)$ & $\mathbf{R}_{\mathrm{MNI}}$ & $R_{\max }$ & $K_{\text {MNN }}\left(\sum R_{\text {MNN }}\right)$ & $K_{\max }\left(\sum R_{\max }\right)$ & $k \%$ & $K R_{k}$ & $\mathrm{KW}_{\mathrm{k}}$ & $\mathrm{ks}_{\mathrm{o}}$ & $\mathbf{R S}_{\text {MNNo }}$ & $\mathbf{R S}_{\max }$ & KS\% & $\mathrm{PR}_{0}$ \\
\hline \multirow{8}{*}{1} & \multirow{8}{*}{ Information Phase } & $\begin{array}{l}\text { Kemudahan akses dari situs web dan } \\
\text { produk-produknya }\end{array}$ & EOU01 & 1.79 & 0.95 & 0.70 & 0.66 & \multirow{8}{*}{3.19} & -1.90 & 1.90 & \multirow{8}{*}{-13.87} & \multirow{8}{*}{13.87} & \multirow{8}{*}{$61.49 \%$} & \multirow{8}{*}{0.46} & \multirow{8}{*}{11.73} & & \multirow{26}{*}{-43.4} & \multirow{26}{*}{43.40} & \multirow{26}{*}{$57.63 \%$} & \multirow{26}{*}{0.3} \\
\hline & & Struktur isi & EOU02 & 1.68 & 0.92 & 0.80 & 0.74 & & -1.84 & 1.84 & & & & & & \multirow{24}{*}{6.62} & & & & \\
\hline & & Kuantitas informasi & EOU03 & 1.84 & 0.96 & 0.85 & 0.82 & & \begin{tabular}{|c|c|}
$-1,92$ \\
\end{tabular} & 1.92 & & & & & & & & & & \\
\hline & & Kualitas isi & USEF01 & 1.84 & 0.96 & 0.75 & 0.72 & & -1.92 & 1.92 & & & & & & & & & & \\
\hline & & $\begin{array}{l}\text { Menyampaikan manfaat-manfaat dari } \\
\text { harga }\end{array}$ & USEF02 & 1.32 & 0.83 & 0.50 & 0.42 & & -1.66 & 1.66 & & & & & & & & & & \\
\hline & & $\begin{array}{l}\begin{array}{l}\text { Membundel produk-produk dan } \\
\text { layanan-layanannya }\end{array} \\
\end{array}$ & USEF03 & 1.21 & 0.80 & 0.05 & 0.04 & & -1.61 & 1.61 & & & & & & & & & & \\
\hline & & Sistem-sistem rekomendasi & USEF04 & 1.26 & 0.82 & -0.25 & -0.20 & & -1.63 & 1.63 & & & & & & & & & & \\
\hline & & Menggunakan hypermedia & USEF05 & 0.79 & 0.70 & 0.00 & 0.00 & & $\frac{1.40}{-1.40}$ & 1.40 & & & & & & & & & & \\
\hline \multirow[b]{2}{*}{2} & \multirow[b]{2}{*}{ Agreement Phase } & Desain dari prosedur pemesanan & EOU04 & 1.63 & 0.91 & 0.60 & 0.54 & \multirow[b]{2}{*}{0.99} & -1.82 & 1.82 & \multirow[b]{2}{*}{-3.45} & \multirow[b]{2}{*}{3.45} & \multirow[b]{2}{*}{$64.41 \%$} & \multirow[b]{2}{*}{0.58} & \multirow[b]{2}{*}{2.89} & & & & & \\
\hline & & 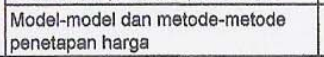 & USEF06 & 1.26 & 0.82 & 0.55 & 0.45 & & -1.63 & 1.63 & & & & & & & & & & \\
\hline \multirow{3}{*}{3} & \multirow{3}{*}{ Settlement Phase } & Integrasi dari layanan-layanan umum & EOU05 & 1.37 & 0.84 & 0.00 & 0.00 & & -1.69 & 1.69 & & & & & & & & & & \\
\hline & & $\begin{array}{l}\text { Integrasi dari aplikasi-aplikasi e- } \\
\text { commerce }\end{array}$ & USEF07 & 1.32 & 0.83 & -0.10 & -0.08 & 0.00 & \begin{tabular}{|c|c|}
-1.00 \\
-1.66
\end{tabular} & 1,60 & -5.03 & 5.03 & $50.01 \%$ & 0.00 & 4.06 & & & & & \\
\hline & & \begin{tabular}{|l} 
Commerce \\
Perutean dan penelusuran \\
\end{tabular} & USEFOB & 1.37 & 0.84 & 0.10 & 0.08 & & \begin{tabular}{|l}
-1.66 \\
-1.69 \\
\end{tabular} & $\frac{1.66}{1.69}$ & & & & & & & & & & \\
\hline 4 & After-Sales P Pas & Akses kepada dukungan pelanggan & EOU06 & 1.42 & 0.86 & 0.20 & 0.17 & 0.30 & -1.71 & 1.71 & -3.42 & 3.42. & $54.38 \%$ & 0.18 & 2.84 & & & & & \\
\hline 4 & Affer-Sales Phase & Kinerja dari dukungan pelanggan & USEF09 & 1.42 & 0.86 & 0.15 & 0.13 & 0.30 & -1.71 & 1.71 & -3.42 & ${ }^{3.42} \mathrm{r}$ & 54.38\% & 0.18 & \begin{tabular}{|l|l|} 
& \\
\end{tabular} & & & & & \\
\hline & & Akses ke sebuah komunitas virtual & EOU07 & 0.79 & 0.70 & -0.30 & -0.21 & & -1.40 & 1.40 & & & & & & & & & & \\
\hline & & \begin{tabular}{l|}
$\begin{array}{l}\text { Keuntungan dari relasi-relasi didalam } \\
\text { komunitas }\end{array}$ \\
\end{tabular} & USEF10 & 0.74 & 0.69 & -0.10 & -0.07 & & -1.37 & 1.37 & & & & & & & & & & \\
\hline 5 & Component & $\begin{array}{l}\begin{array}{l}\text { Keuntungan dari ketersediaan isi } \\
\text { didalam komunitas }\end{array} \\
\end{array}$ & USEF11 & 0.79 & 0.70 & -0.30 & -0.21 & -0.75 & -1.40 & 1.40 & -5.48 & 5.48 & $43.15 \%$ & -0.27 & 2.95 & & & & & \\
\hline & & \begin{tabular}{|l|}
$\begin{array}{l}\text { Pemberdayaan pelanggan yang } \\
\text { dihasilkan dari komunitas }\end{array}$ \\
\end{tabular} & USEF12 & 0.63 & 0.66 & -0.40 & -0.26 & & & 1.32 & & & & & & & & & & \\
\hline & & Ketersediaan sistem & EOU08 & 1.58 & 0.90 & 0.85 & 0.76 & & \begin{tabular}{|l}
-1.02 \\
-1.79 \\
\end{tabular} & $\frac{7.26}{1.79}$ & & & & & & & & & & \\
\hline & & Desain dari antarmuka pengguna & EOU09 & 1.53 & 0.88 & 0.30 & 0.26 & & \begin{tabular}{|l|l}
-77 \\
\end{tabular} & 1.77 & & & & & & & & & & \\
\hline & & $\begin{array}{l}\text { Meningkatkan produktivitas dengan } \\
\text { menghemat waktu }\end{array}$ & USEF 13 & 1.53 & 0.88 & 0.75 & 0.66 & & -1.77 & 1.77 & & & & & & & & & & \\
\hline 6 & Final Section & Interaksi & USEF14 & 1.42 & 0.86 & 0.35 & 0.30 & 2.89 & \begin{tabular}{|l|l|}
-1.71 \\
\end{tabular} & 1.71 & -12.16 & 12.16 & $61.89 \%$ & 0.48 & 10.32 & & & & & \\
\hline & & \begin{tabular}{|l} 
Fungsi-fungsi personalisasi \\
\end{tabular} & USEF15 & 0.89 & 0.72 & -0.20 & -0.14 & & -1.45 & 1.45 & & & & & & & & & & \\
\hline & & $\begin{array}{l}\text { Kepercayaan dari rekan bisnis } \\
\text { (pemasok) }\end{array}$ & TRUST1 & 1.58 & 0.90 & 0.75 & 0.67 & & -1.79 & 1.79 & & & & & & & & & & \\
\hline & & $\begin{array}{l}\text { Hal yang dapat dipercaya dari situs } \\
\text { web dan situasi legal }\end{array}$ & TRUST2 & 1.79 & 0.95 & 0.40 & 0.38 & & -1.90 & 1.90 & & & & & & & & & & \\
\hline
\end{tabular}




\begin{tabular}{|c|c|c|c|c|c|c|c|c|c|c|c|c|c|c|c|c|c|c|c|c|}
\hline \multicolumn{21}{|c|}{ erlangga.co.id } \\
\hline No. & Category $\left(K_{k}\right)$ & Criteria (Xi) & Code & $\begin{array}{l}\text { Importance: } W_{1} \\
\text { (Range -21+2) }\end{array}$ & $\begin{array}{l}\text { Importance: } \mathrm{Wg}_{1} \\
\text { (Range 0-1) }\end{array}$ & $\begin{array}{l}\text { Evaluation: Average }\left(r_{1}\right) \\
\text { (Range -2/+2) }\end{array}$ & $\begin{array}{l}\text { Weighted Value } R_{B^{\prime}} \\
R_{1}=W_{g_{1}} \text { Average }\left(r_{1}\right)\end{array}$ & $K_{k}\left(\Sigma R_{1}\right)$ & $R_{\text {mN }}$ & $R_{\max } \mid$ & $K_{\text {man }}\left(\sum R_{\text {min }}\right)$ & 1) $\left|K_{\max }\left(\sum R_{\max }\right)\right|$ & 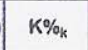 & $K R_{k}$ & $k W_{k}$ & Ks。 & $\mid \mathrm{RS}_{\text {mNa }}$ & $\mathbf{R S}_{\max }$ & kS $\%$ 。 & $P R_{0}$ \\
\hline \multirow{8}{*}{1} & \multirow{8}{*}{ Information Phase } & $\begin{array}{l}\text { Kemudahan akses dari } \\
\text { situs web dan produk- }\end{array}$ & EOU01 & 1.79 & 0.95 & 1.37 & 1.30 & \multirow{8}{*}{6.25} & -1.90 & 1.90 & \multirow{8}{*}{-13.87} & \multirow{8}{*}{13.87} & \multirow{8}{*}{$72.53 \%$} & \multirow{8}{*}{0.90} & \multirow{8}{*}{11.7} & \multirow{23}{*}{14.5} & \multirow{23}{*}{$\begin{array}{l}6 \\
6\end{array}-43.4$} & \multirow{23}{*}{43.40} & \multirow{23}{*}{$66.78 \%$} & \multirow{23}{*}{0.67} \\
\hline & & \begin{tabular}{|l|} 
Struktur isi \\
\end{tabular} & EOU02 & 1.68 & 0.92 & 1.32 & 1.21 & & \begin{tabular}{|l|}
-1.84 \\
\end{tabular} & 1.84 & & & & & & & & & & \\
\hline & & \begin{tabular}{|l} 
Kuantitas informasi \\
\end{tabular} & EOU03 & 1.84 & 0.96 & 1.26 & 1.21 & & -1.92 & 1.92 & & & & & & & & & & \\
\hline & & Kualitas isi & USEF01 & 1.84 & 0.96 & 0.95 & 0.91 & & \begin{tabular}{|l|}
-1.92 \\
\end{tabular} & 1.92 & & & & & & & & & & \\
\hline & & $\begin{array}{l}\text { Menyampaikan manfaat- } \\
\text { manfaat dari harga }\end{array}$ & USEF02 & 1.32 & 0.83 & 0.63 & 0.52 & & \begin{tabular}{|l|}
1.1 .62 \\
-1.66 \\
\end{tabular} & 1.66 & & & & & & & & & & \\
\hline & & Membundel produk-produk & USEFO3 & 121 & 0.80 & 0.32 & 0.26 & & \begin{tabular}{|c|}
-1.00 \\
-1.61 \\
\end{tabular} & 1.00 & & & & & & & & & & \\
\hline & & 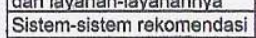 & USEFO4 & $\frac{1.21}{1.26}$ & 0.82 & 0.21 & 0.17 & & \begin{tabular}{|l|l|}
$\frac{-1.01}{-1.63}$ \\
\end{tabular} & $\frac{1.01}{1.63}$ & & & & & & & & & & \\
\hline & & \begin{tabular}{|l|} 
Menggunakan hypermedia \\
\end{tabular} & USEFO5 & 0.79 & 0.70 & 0.95 & 0.66 & & \begin{tabular}{|c|}
-1.40 \\
\end{tabular} & 1.40 & & & & & & & & & & \\
\hline \multirow[b]{2}{*}{2} & \multirow[b]{2}{*}{ Agreement Phase } & $\begin{array}{l}\text { Desain dari prosedur } \\
\end{array}$ & EOUO4 & 1.63 & 0.91 & 0.89 & 0.81 & \multirow[b]{2}{*}{1.36} & \begin{tabular}{|l|l|}
-1.82 \\
\end{tabular} & 1.82 & \multirow[b]{2}{*}{-3.45} & \multirow[b]{2}{*}{3.45} & \multirow[b]{2}{*}{$69.77 \%$} & \multirow[b]{2}{*}{0.79} & \multirow[b]{2}{*}{2.89} & & & & & \\
\hline & & $\begin{array}{l}\text { Model-model dan metode- } \\
\text { metode penetapan harga }\end{array}$ & USEF0 6 & 1.26 & 0.82 & 0.68 & 0.55 & & -1.63 & 1.63 & & & & & & & & & & \\
\hline \multirow{3}{*}{3} & & $\begin{array}{l}\text { Integrasi daril layanan- } \\
\text { layanan umum }\end{array}$ & EOU05 & 1.37 & 0.84 & 0.32 & 0.27 & \multirow{3}{*}{1.02} & -1.69 & 1.69 & \multirow{3}{*}{-5.03} & & & & & & & & & \\
\hline & Settlement Phase & Integrasi dari aplikasi- & LNO00 & & 0.83 & 0.32 & 0.27 & & & & & 5.03 & $60.18 \%$ & 0.41 & 4.06 & & & & & \\
\hline & & \begin{tabular}{|l} 
aplikasi -commerce \\
Perutean dan penelusuran
\end{tabular} & $\frac{\text { USEF07 }}{\text { USEF08 }}$ & $\frac{1.32}{1.37}$ & 0.84 & 0.58 & 0.49 & & \begin{tabular}{|c|c|}
-1.66 \\
-1.69 \\
\end{tabular} & \begin{tabular}{|l|l|}
1.66 \\
1.69 \\
\end{tabular} & & & & & & & & & & \\
\hline 4 & After-Sales Phase & Akses kepada dukungan & $\begin{array}{l}\text { EOU06 } \\
\text { USEF09 }\end{array}$ & $\frac{1.42}{1.42}$ & 0.86 & 0.74 & 0.63 & 0.91 & \begin{tabular}{|l|l|}
-1.71 \\
1.71
\end{tabular} & \begin{tabular}{|l|}
1.71 \\
1.71 \\
\end{tabular} & -3.42 & 3.42 & $63.25 \%$ & 0.53 & 2.84 & & & & & \\
\hline & & \begin{tabular}{|l|} 
Kineria dan dukungan \\
Akses ke sebuah komunitas \\
virtual
\end{tabular} & EOUO7 & 0.79 & 0.86 & 0.21 & 0.21 & & \begin{tabular}{|l|}
-1.17 \\
-1.40 \\
\end{tabular} & 1.40 & & & & & & & & & & \\
\hline & & \begin{tabular}{|l|} 
Keuntungan dari relasi- \\
relasi didalam komunitas
\end{tabular} & USEF10 & 0.74 & 0.69 & -0.05 & -0.03 & & \begin{tabular}{|l|}
-1.37 \\
\end{tabular} & 1.37 & & & & & & & & & & \\
\hline 5 & $\begin{array}{l}\text { Community } \\
\text { Component }\end{array}$ & $\begin{array}{l}\text { Keuntungan dari } \\
\text { ketersediaan isi di dalam } \\
\text { komunitas }\end{array}$ & USEF11 & 0.79 & 0.70 & 0.58 & 0.40 & 0.69 & -1.40 & 1.40 & -5.48 & 5.48 & $56.28 \%$ & 0.25 & 2.95 & & & & & \\
\hline & & $\begin{array}{l}\text { Pemberdayaan pelanggan } \\
\text { yang dihasilkan dari } \\
\text { komunitas }\end{array}$ & USEF12 & 0.63 & 0.66 & 0.26 & 0.17 & & -1.32 & 1.32 & & & & & & & & & & \\
\hline & & \begin{tabular}{|l} 
Ketersediaan sistem \\
Desain dari antarmuka \\
\end{tabular} & $\begin{array}{l}\text { EOUOB } \\
\text { EOUO9 }\end{array}$ & $\frac{1.58}{1.53}$ & 0.90 & $\frac{0.79}{1.00}$ & 0.71 & & \begin{tabular}{|l|}
-1.79 \\
-1.77 \\
\end{tabular} & $\begin{array}{l}1.79 \\
1.77 \\
\end{array}$ & & & & & & & & & & \\
\hline & & $\begin{array}{l}\text { Meningkatkan produktivitas } \\
\text { dengan menghemat waktu }\end{array}$ & USEF13 & 1.53 & 0.88 & 0.84 & 0.74 & & -177 & 177 & & & & & & & & & & \\
\hline 6 & Final Section & \begin{tabular}{|l|} 
Interaksi \\
Fungsi-fungsi personalisasi \\
\end{tabular} & $\begin{array}{l}\text { USEF14 } \\
\text { USEF15 }\end{array}$ & $\frac{1.42}{0.89}$ & $\frac{0.86}{0.72}$ & 0.74 & $\frac{0.63}{0.30}$ & 4.34 & \begin{tabular}{|l|l|}
-1.71 \\
-1.45 \\
\end{tabular} & \begin{tabular}{|l|}
1.71 \\
1.45 \\
\end{tabular} & -12.16 & 12.16 & $67.83 \%$ & 0.71 & $\mid$\begin{tabular}{|l|}
$\mid 10.32$ \\
\end{tabular} & & & & & \\
\hline & & $\begin{array}{l}\text { Kepercayaan dari rekan } \\
\text { bisnis (pemasosok }\end{array}$ & TRUST1 & 1.58 & 0.90 & 0.58 & 0.52 & & \begin{tabular}{|l|}
-1.79 \\
\end{tabular} & 1.79 & & & & & & & & & & \\
\hline & & 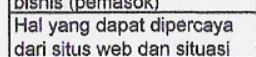 & TRUST2 & 1.79 & 0.95 & 0.58 & 0.55 & & \begin{tabular}{|l|}
-1.90 \\
-1.90
\end{tabular} & 1.90 & & & & & & & & & & \\
\hline
\end{tabular}




\begin{tabular}{|c|c|c|c|c|c|c|c|c|c|c|c|c|c|c|c|c|c|c|c|c|}
\hline \multicolumn{21}{|c|}{ gramediaonline.com } \\
\hline No. & Category $\left(K_{k}\right)$ & Criteria (Xi) & Code & $\begin{array}{l}\text { Importance: } W_{i} \\
(\text { Range -21+2) }\end{array}$ & $\begin{array}{l}\text { Importance: } \mathrm{Wg}_{\mathrm{i}} \\
\text { (Range 0-1) }\end{array}$ & $\begin{array}{l}\text { Evaluation: Average }\left(r_{i}\right) \\
\text { (Range }-2 /+2)\end{array}$ & \begin{tabular}{|l|} 
Weighted Value $R_{\mathrm{t}}$ \\
$R_{1}=W_{g_{1}}^{*}$ Average $\left(r_{1}\right)$
\end{tabular} & $K_{k}\left(\Sigma R_{1}\right)$ & $\mathrm{R}_{\text {MNI }}$ & $R_{\operatorname{maxi}}$ & $K_{\text {MNI }}\left(\Sigma R_{\text {MNi }}\right)$ & $K_{\text {maxi }}\left(\sum R_{\text {maxi }}\right)$ & $K \%$ k & $K R_{k}$ & $\mathrm{KW}_{\mathrm{k}}$ & $\mathrm{KS}$ 。 & $\mathrm{RS}_{\text {MNo }}$ & $\mathrm{RS}_{\text {maxo }}$ & KS\%。 & $\mathrm{PR}_{\mathrm{o}}$ \\
\hline \multirow{8}{*}{1} & \multirow{8}{*}{ Information Phase } & $\begin{array}{l}\text { Kemudahan akses dari situs } \\
\text { web dan produk-produknva }\end{array}$ & EOU01 & 1.79 & 0.95 & 1.11 & 1.05 & \multirow{8}{*}{3.13} & -1.90 & 190 & \multirow{8}{*}{-13.87} & \multirow{8}{*}{13.87} & \multirow{8}{*}{$61.27 \%$} & \multirow{8}{*}{0.45} & \multirow{8}{*}{11.7} & & \multirow{26}{*}{$|-43.40|$} & \multirow{26}{*}{\begin{tabular}{|l|} 
\\
\end{tabular}} & \multirow{26}{*}{$58.64 \%$} & \multirow{26}{*}{0.35} \\
\hline & & \begin{tabular}{|l} 
wed dan proakk-proguknva \\
Struktur isi
\end{tabular} & EOUO2 & $\frac{1.168}{1.68}$ & 0.92 & 0.79 & 0.73 & & $\frac{-1.90}{-1.84}$ & $\frac{1.90}{1.84}$ & & & & & & & & & & \\
\hline & & Kuantitas informasi & EOU03 & 1.84 & 0.96 & 0.74 & 0.71 & & -1.92 & 1.92 & & & & & & & & & & \\
\hline & & $\begin{array}{l}\text { Kualitas isi } \\
\end{array}$ & USEF01 & 1.84 & 0.96 & & 0.51 & & -1.92 & 1.92 & & & & & & & & & & \\
\hline & & $\begin{array}{l}\text { Menyampaikan manfaat- } \\
\text { manfaat dari harga }\end{array}$ & USEF02 & 1.32 & 0.83 & 0.32 & 0.27 & & -1.66 & 1.66 & & & & & & & & & & \\
\hline & & Membundel produk-produk & USEF03 & & 0.80 & 0.16 & 0.13 & & -1.61 & 161 & & & & & & & & & & \\
\hline & & $\mid \begin{array}{l}\text { dan lavananan-lavanannnya } \\
\text { Sistem-sistem rekomendasi }\end{array}$ & $\begin{array}{l}\text { USEFU3 } \\
\text { USEF04 }\end{array}$ & $\frac{1.21}{1.26}$ & 0.82 & -0.42 & -0.34 & & $\frac{-1.61}{-1.63}$ & $\frac{1.61}{1.63}$ & & & & & & & & & & \\
\hline & & Menggunakan hypermedia & USEF05 & 0.79 & 0.70 & 0.11 & 0.08 & & -1.40 & 1.40 & & & & & & & & & & \\
\hline \multirow{2}{*}{2} & \multirow{2}{*}{ Agreement Phase } & $\begin{array}{l}\text { Desain dari prosedur } \\
\text { pemesanan }\end{array}$ & EOU04 & 1.63 & 0.91 & 0.63 & 0.57 & \multirow{2}{*}{0.87} & -182 & 182 & \multirow{2}{*}{-3.45} & \multirow{2}{*}{3.45} & \multirow{2}{*}{$62.67 \%$} & \multirow{2}{*}{0.51} & \multirow{2}{*}{2.89} & & & & & \\
\hline & & Modelmodel dan metode- & USEF06 & 126 & 0.82 & 0.37 & 0.30 & & -1.63 & 163 & & & & & & & & & & \\
\hline \multirow{3}{*}{3} & \multirow{3}{*}{ Settlement Phase } & 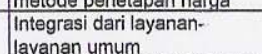 & EOU05 & 1.37 & 0.84 & 0.21 & 0.18 & & -1.69 & 1.00 & & & & & & & & & & \\
\hline & & $\begin{array}{l}\text { Alyanan umum } \\
\text { Integrasi dari aplikasi- }\end{array}$ & USEFO7 & 1.01 & 0.83 & 0.21 & 0.17 & 0.17 & -1.05 & 1.00 & -5.03 & 5.03 & $51.73 \%$ & 0.07 & 4.06 & & & & & \\
\hline & & \begin{tabular}{|l} 
aplikasi e-commerce \\
Perutean dan penelusuran
\end{tabular} & $\begin{array}{l}\text { USEFU } \\
\text { USEFO }\end{array}$ & $\frac{1.32}{1.37}$ & 0.84 & $\frac{0.21}{-0.21}$ & -0.18 & & $\begin{array}{r}-1.66 \\
-1.69\end{array}$ & $\frac{1.66}{1.69}$ & & & & & & & & & & \\
\hline & & Akses kepada dukungan & & & 0.86 & 0.05 & 0.04 & & & & & & & & & & & & & \\
\hline 4 & After-Sales Phase & pelanggan & EOU06 & 1.42 & .00 & 0.05 & 0.04 & -0.09 & -1.71 & 1.71 & -3.42 & 3.42 & $48.63 \%$ & -0.06 & 2.84 & 750 & & & & \\
\hline & & 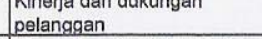 & USEF09 & 1.42 & 0.86 & -0.16 & -0.14 & & -1.71 & 1.71 & & & & & & 1.00 & & & & \\
\hline & & $\begin{array}{l}\text { Akses ke sebuah komunitas } \\
\text { virtual }\end{array}$ & EOU07 & 0.79 & 0.70 & -0.58 & -0.40 & & -1.40 & 1.40 & & & & & & & & & & \\
\hline & & $\begin{array}{l}\text { Keuntungan dari relasi-relasi } \\
\text { didalam komunitas }\end{array}$ & USEF 10 & 0.74 & 0.69 & -0.32 & -0.22 & & -1.37 & 1.37 & & & & & & & & & & \\
\hline 5 & $\begin{array}{l}\text { Community } \\
\text { Component }\end{array}$ & $\begin{array}{l}\begin{array}{l}\text { Keuntungan dari } \\
\text { ketersediaan isi didalam } \\
\text { komunitas }\end{array} \\
\end{array}$ & USEF 11 & 0.79 & 0.70 & -0.32 & -0.22 & -0.95 & -1.40 & 1.40 & -5.48 & 5.48 & $41.30 \%$ & -0.35 & 2.95 & & & & & \\
\hline & & $\begin{array}{l}\text { Pemberdayaan pelanggan } \\
\text { yang dihasilkan dari } \\
\text { komunitas }\end{array}$ & USEF 12 & 0.63 & 0.66 & -0.16 & -0.11 & & -1.32 & 1.32 & & & & & & & & & & \\
\hline & & Ketersediaan sistem & EOU08 & 1.58 & 0.90 & 0.84 & 0.75 & & -1.79 & 1.79 & & & & & & & & & & \\
\hline & & \begin{tabular}{|l|}
$\begin{array}{l}\text { Desain dari antarmuka } \\
\text { pengguna }\end{array}$ \\
\end{tabular} & EOUO9 & 1.53 & 0.88 & 0.68 & 0.60 & & -1.77 & 1.77 & & & & & & & & & & \\
\hline & & $\begin{array}{l}\text { Meningkatkan produktivitas } \\
\text { dengan menghemat waktu }\end{array}$ & USEF13 & 1.53 & 0.88 & 0.63 & 0.56 & & 77 & \begin{tabular}{|l|l|} 
& 1.77 \\
\end{tabular} & & & & & & & & & & \\
\hline 6 & Final Section & \begin{tabular}{|l} 
Interaksi \\
Fungsi-fungsi personalisasi \\
\end{tabular} & \begin{tabular}{|l|} 
USEF 14 \\
USEF 15 \\
\end{tabular} & $\frac{1.42}{0.89}$ & 0.86 & $\frac{0.42}{-0.05}$ & $\begin{array}{l}0.36 \\
-0.04\end{array}$ & 4.37 & $\begin{array}{l}\frac{-1.71}{-1.45} \\
\end{array}$ & $\frac{1.71}{1.45}$ & -12.16 & 12.16 & $67.96 \%$ & 0.72 & 10.32 & & & & & \\
\hline & & $\begin{array}{l}\begin{array}{l}\text { Kepercayaan dari rekan } \\
\text { bisnis (pemasok) }\end{array} \\
\end{array}$ & TRUST1 & 1.58 & 0.90 & 1.16 & 1.04 & & -1.79 & 1.79 & & & & & & & & & & \\
\hline & & $\begin{array}{l}\begin{array}{l}\text { Hal yang dapat dipercaya } \\
\text { darr situs web dan situasi } \\
\text { legal }\end{array} \\
\end{array}$ & TRUST2 & 1.79 & 0.95 & 1.16 & 1.10 & & -1.90 & 1.90 & & & & & & & & & & \\
\hline
\end{tabular}




\begin{tabular}{|c|c|c|c|c|c|c|c|c|c|c|c|c|c|c|c|c|c|c|c|c|}
\hline \multicolumn{21}{|c|}{ kutukutubuku.com } \\
\hline No. & Category $\left(K_{k}\right)$ & Criteria (Xi) & Code & $\begin{array}{l}\text { Importance: } W_{1} \\
\text { (Range -21+2) }\end{array}$ & $\begin{array}{l}\mid \begin{array}{l}\text { Importance: } \mathrm{Wg}_{1} \\
\text { (Range 0-1) }\end{array} \\
\end{array}$ & $\begin{array}{l}\text { Evaluation: Average }\left(r_{i}\right) \\
\text { (Range -2l+2) }\end{array}$ & $\begin{array}{l}\text { Weighted Value } R_{i 1} \\
R_{1}=W_{g_{1}} \text { "Average }\left(r_{i}\right)\end{array}$ & $K_{k}\left(\Sigma R_{k}\right)$ & $R_{\text {miNi }}$ & $\left|R_{\operatorname{maxi}}\right|$ & $K_{\text {MN }}\left(\Sigma R_{\text {MNM }}\right)$ & $K_{\operatorname{maxi}}\left(\Sigma R_{\text {maxi }}\right)$ & $K \%_{k}$ & $K R_{k}$ & $\left|k W_{k}\right|$ & $\mathrm{KS}_{\mathrm{o}}$ & $\mathrm{RS}_{\text {MNO }}$ & $\mathrm{RS}_{\max }$ & $\mathrm{KS} \%$ & $\mathrm{PR}_{0}$ \\
\hline \multirow{8}{*}{1} & \multirow{8}{*}{ Information Phase } & $\begin{array}{l}\text { Kemudahan akses dari situs } \\
\text { wab dan produk-produknya }\end{array}$ & EOU01 & 1.79 & 0.95 & 0.95 & 0.90 & \multirow{8}{*}{6.00} & -1.90 & 1.90 & \multirow{8}{*}{-13.87} & \multirow{8}{*}{13.87} & \multirow{8}{*}{$71.65 \%$} & \multirow{8}{*}{0.87} & \multirow{8}{*}{11.73} & & \multirow{26}{*}{-43.40} & \multirow{26}{*}{43.40} & \multirow{26}{*}{$68.28 \%$} & \multirow{26}{*}{0.73} \\
\hline & & \begin{tabular}{|l|} 
Struktur isi \\
\end{tabular} & EOU02 & 1.68 & 0.92 & 1.25 & 1.15 & & -1.84 & 1.84 & & & & & & & & & & \\
\hline & & $\begin{array}{l}\text { Kuantitas informasi } \\
\end{array}$ & EOUO3 & 1.84 & 0.96 & 1.25 & 1.20 & & $\begin{array}{ll}-1.94 \\
-1.92 \\
\end{array}$ & 1.92 & & & & & & & & & & \\
\hline & & Kualitas isi & USEF01 & 1.84 & 0.96 & 1.25 & 1.20 & & -1.92 & 1.92 & & & & & & & & & & \\
\hline & & Menyampaikan manfaat- & USEFO2 & 1.32 & 0.83 & 0.90 & 0.75 & & -1.66 & 166 & & & & & & & & & & \\
\hline & & $\begin{array}{l}\text { Membundel produk-produk } \\
\text { dan layanan-layanannya }\end{array}$ & USEF03 & 1.21 & 0.80 & 0.60 & 0.48 & & -161 & & & & & & & & & & & \\
\hline & & Sistem-sistem rekomendasi & USEFO4 & 1.26 & 0.82 & 0.40 & 0.33 & & $\frac{-1.61}{-1.63}$ & \begin{tabular}{|l|}
1.63 \\
1.63
\end{tabular} & & & & & & & & & & \\
\hline & & \begin{tabular}{|l|} 
Menggunakan hypermedia \\
\end{tabular} & USEF05 & 0.79 & 0.70 & 0.00 & 0.00 & & $\frac{-1.050}{-1.40}$ & 1.40 & & & & & & & & & & \\
\hline \multirow{2}{*}{2} & \multirow{2}{*}{ Agreement Phase } & Desain dari prosedur & EOU04 & 163 & 0.91 & 1.15 & 1.04 & \multirow[b]{2}{*}{1.78} & -182 & & \multirow[b]{2}{*}{-3.45} & \multirow[b]{2}{*}{3.45} & \multirow[b]{2}{*}{$75.79 \%$} & \multirow[b]{2}{*}{1.03} & \multirow[b]{2}{*}{2.89} & & & & & \\
\hline & & $\begin{array}{l}\text { Model-model dan metode- } \\
\text { metode penetapan harga }\end{array}$ & USEFO6 & 1.26 & 0.82 & 0.90 & 0.73 & & \begin{tabular}{|l|}
-1.82 \\
-1.63 \\
\end{tabular} & \begin{tabular}{|l|}
1.82 \\
1.63 \\
\end{tabular} & & & & & & & & & & \\
\hline \multirow{3}{*}{3} & \multirow{3}{*}{ Settlement Phase } & $\begin{array}{l}\text { Integrasi dari layanan- } \\
\text { layanan umum }\end{array}$ & EOU05 & 1.37 & 0.84 & 0.55 & 0.46 & & -1.69 & 1.69 & & & & & & & & & & \\
\hline & & \begin{tabular}{|l} 
Integrasi dari aplikasi- \\
aplikasi e-commerce
\end{tabular} & USEF07 & 1.32 & 0.83 & 0.45 & 0.37 & 1.30 & \begin{tabular}{|c|}
-1.66 \\
\end{tabular} & 1.66 & -5.03 & 5.03 & $62.92 \%$ & 0.52 & 4.06 & & & & & \\
\hline & & \begin{tabular}{|l|l|l|l} 
Perutean dan penelusuran \\
\end{tabular} & USEF08 & 1.37 & 0.84 & 0.55 & 0.46 & & -1.69 & 1.69 & & & & & & & & & & \\
\hline & & $\begin{array}{l}\text { Akses kepada dukungan } \\
\text { pelanggan }\end{array}$ & EOU 06 & 1.42 & 0.86 & 0.55 & 0.47 & & -1.71 & 1.71 & & & & & & 15.87 & & & & \\
\hline 4 & After-Sales Phase & Kinerja dari dukungan & USEFO9 & 1.42 & 0.86 & 0.30 & 0.26 & 0.73 & \begin{tabular}{|c|}
-1.71 \\
-1.71 \\
\end{tabular} & 1.17 & -3.42 & 3.42 & $60.63 \%$ & 0.43 & 2.84 & & & & & \\
\hline & & \begin{tabular}{|l|} 
pelangggan \\
Akses ke sebuah komunitas \\
virtual
\end{tabular} & EOUO7 & 0.79 & 0.70 & 0.25 & 0.17 & & \begin{tabular}{|l|}
-1.77 \\
-1.40 \\
\end{tabular} & 1.71 & & & & & & & & & & \\
\hline L & Community & $\begin{array}{l}\text { Keuntungan dari relasi- } \\
\text { relasid didalam komunitas }\end{array}$ & USEF10 & 0.74 & 0.69 & 0.40 & 0.27 & & \begin{tabular}{|l|l|}
-137 \\
\end{tabular} & 137 & & & & & & & & & & \\
\hline${ }^{5}$ & Component & $\begin{array}{l}\text { Keuntungan dari } \\
\text { ketersediaan isi didalam }\end{array}$ & USEF11 & 0.79 & 0.70 & 0.20 & 0.14 & 0.69 & \begin{tabular}{|c|}
-1.40 \\
\end{tabular} & 1.40 & -5.48 & 5.48 & $56.27 \%$ & 0.25 & 2.95 & & & & & \\
\hline & & $\begin{array}{l}\text { Pemberdayaan pelanggan } \\
\text { yang dihasilkan dari }\end{array}$ & USEF12 & 0.63 & 0.66 & 0.15 & 0.10 & & $\mid-1.32$ & 1.32 & & & & & & & & & & \\
\hline & & Ketersediaan sistem & EOU08 & 1.58 & 0.90 & 0.90 & 0.81 & & -1.79 & 1.79 & & & & & & & & & & \\
\hline & & $\begin{array}{l}\text { Desain dari antarmuka } \\
\text { pengguna }\end{array}$ & EOU09 & 1.53 & 0.88 & 1.05 & 0.93 & & \begin{tabular}{|l|}
-1.77 \\
\end{tabular} & 1.77 & & & & & & & & & & \\
\hline & & Meningkatkan produktivitas & USEF13 & 153 & 0.88 & 1.05 & 0.93 & & \begin{tabular}{|c|}
-1.17 \\
-1.77 \\
\end{tabular} & 1.77 & & & & & & & & & & \\
\hline 6 & Final Section & \begin{tabular}{|l|} 
Interaksi \\
\end{tabular} & $\begin{array}{l}\text { USEF14 } \\
\text { USEF14 }\end{array}$ & 1.42 & 0.86 & 0.95 & 0.81 & 5.37 & \begin{tabular}{|l|l|}
-1.71 \\
-1.5
\end{tabular} & \begin{tabular}{|l|}
1.11 \\
1.71 \\
\end{tabular} & -12.16 & 12.16 & $72.08 \%$ & 0.88 & 10.32 & & & & & \\
\hline & & \begin{tabular}{|l|} 
Fungsi-fungsi personalisasi \\
Kepercayaan dari rekan \\
\end{tabular} & USEF15 & 0.89 & 0.72 & 0.45 & 0.33 & & -1.45 & 1.45 & & & & & & & & & & \\
\hline & & $\begin{array}{l}\text { Kepercayaan dari rekan } \\
\text { bisnis (pemasok) }\end{array}$ & TRUST1 & 1.58 & 0.90 & 0.70 & 0.63 & & -1.79 & 1.79 & & & & & & & & & & \\
\hline & & $\begin{array}{l}\text { Hal yang dapat dipercaya } \\
\text { dari situs web dan situasi }\end{array}$ & TRUST2 & 1.79 & 0.95 & 1.00 & 0.95 & & -1.90 & $\mid 1.90$ & & & & & & & & & & \\
\hline
\end{tabular}




\begin{tabular}{|c|c|c|c|c|c|c|c|c|c|c|c|c|c|c|c|c|c|c|c|c|}
\hline \multicolumn{21}{|c|}{ amazon.com } \\
\hline No. & Category $\left(K_{k}\right)$ & Criteria $(X \mathrm{I})$ & Code & $\begin{array}{l}\text { Importance: W } \\
\text { (Range -21+2) }\end{array}$ & $\begin{array}{l}\text { Importance: } \mathrm{Wg}_{1} \\
(\text { Range 0-1) }\end{array}$ & \begin{tabular}{|l|}
$\begin{array}{l}\text { Evaluation: Average }\left(r_{i}\right) \\
\text { (Range -2l+2) }\end{array}$ \\
\end{tabular} & $\begin{array}{l}\text { Welghted Value } R_{i} \\
R_{1}=\text { W } g_{1} \text { " Average }\left(r_{i}\right)\end{array}$ & $k_{k}\left(\Sigma R_{1}\right)$ & $R_{\text {MN }}$ & $R_{\max }$ & $K_{\text {MNI }}\left(\sum R_{\text {MNN }}\right)$ & $\left|K_{\max }\left(\sum R_{\max }\right)\right|$ & $\kappa \%$ k & $K R_{k}$ & $K W_{k}$ & $\mathrm{KS}$ 。 & $\mathbf{R S}_{\text {MMo }}$ & $\mathbf{R S}_{\max }$ & $\mathrm{KS} \%$ & $\mathrm{PR}_{\mathrm{o}}$ \\
\hline \multirow{8}{*}{1} & \multirow{8}{*}{ Information Phase } & $\begin{array}{l}\text { Kemudahan akses dari situs web } \\
\text { dan produk-produknya }\end{array}$ & EOU01 & 1.79 & 0.95 & 1.68 & 1.59 & \multirow{8}{*}{9.89} & \begin{tabular}{|l|l|} 
& -1.90 \\
\end{tabular} & 1.90 & \multirow{8}{*}{-13.87} & \multirow{8}{*}{13.87} & \multirow{8}{*}{$85.67 \%$} & \multirow{8}{*}{1.43} & \multirow{8}{*}{11.7} & & \multirow{28}{*}{-43.40} & \multirow{28}{*}{43.40} & \multirow{28}{*}{$82.89 \%$} & \multirow{28}{*}{1.32} \\
\hline & & Struktur isi & \begin{tabular}{|l|l|l|} 
EOU02 \\
\end{tabular} & 1.68 & 0.92 & 1.63 & 1.50 & & \begin{tabular}{|l|}
-1.84 \\
-1.84
\end{tabular} & 1.84 & & & & & & & & & & \\
\hline & & Kuantitas informasi & EOUO3 & 1.84 & 0.96 & 1.37 & 1.32 & & \begin{tabular}{|l|}
-1.92 \\
\end{tabular} & 1.92 & & & & & & & & & & \\
\hline & & Kualitas isi & USEF01 & 1.84 & 0.96 & 1.47 & 1.41 & & \begin{tabular}{|l|l|}
-1.92 \\
\end{tabular} & 1.92 & & & & & & & & & & \\
\hline & & $\begin{array}{l}\text { Menyampaikan manfaat-manfaat } \\
\text { dari harga }\end{array}$ & USEF02 & 1.32 & 0.83 & 1.16 & 0.96 & & \begin{tabular}{|l|}
-1.66 \\
\end{tabular} & 1.66 & & & & & & & & & & \\
\hline & & Membundel produk-produk dan & USEEO3 & 121 & 0.80 & 1.47 & 1.18 & & -161 & & & & & & & & & & & \\
\hline & & 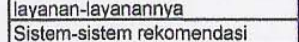 & \begin{tabular}{|l|l|} 
USEFEO4 \\
SEFO4
\end{tabular} & $\frac{7.21}{1.26}$ & 0.82 & 1.42 & 1.16 & & \begin{tabular}{|l|}
-1.61 \\
-1.63 \\
\end{tabular} & $\frac{1.61}{163}$ & & & & & & & & & & \\
\hline & & Menggunakan hypermedia & USEFO5 & 0.79 & 0.70 & 1.11 & 0.77 & & -1.40 & 1.40 & & & & & & & & & & \\
\hline \multirow{2}{*}{2} & \multirow{2}{*}{ Agreement Phase } & Desain dari prosedur pemesanan & EOU 04 & 1.63 & 0.91 & 1.68 & 1.52 & \multirow{2}{*}{2.43} & \begin{tabular}{|l|}
$\mid-1.82$ \\
\end{tabular} & 1.82 & \multirow{2}{*}{-3.45} & \multirow{2}{*}{3.45} & \multirow{2}{*}{$85.26 \%$} & \multirow{2}{*}{1.41} & \multirow{2}{*}{2.89} & & & & & \\
\hline & & $\begin{array}{l}\text { Model-model dan metode- } \\
\text { metode penetapan harga }\end{array}$ & USEF06 & 1.26 & 0.82 & 1.11 & 0.90 & & 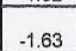 & 1.63 & & & & & & & & & & \\
\hline \multirow{3}{*}{3} & & $\begin{array}{l}\text { Integrasi dari layanan-layanan } \\
\text { umum }\end{array}$ & EOU 5 & 1.37 & 0.84 & 1.47 & 1.24 & & -1.69 & 1.69 & & & & & & & & & & \\
\hline & Settlement Phase & Integrasi dari aplikasi-aplikasi e- & & & 0.83 & 1.37 & 1.14 & 3.53 & & & -5.03 & 5.03 & $85.09 \%$ & 1.40 & 4.06 & & & & & \\
\hline & & $\mid \frac{\text { commerce }}{\text { Perutean dan penelusuran }}$ & \begin{tabular}{|l|l|} 
USEF07 \\
USEFO8
\end{tabular} & $\frac{1.32}{1.37}$ & $\frac{0.03}{0.84}$ & $\frac{1.31}{1.37}$ & $\frac{1.14}{1.15}$ & & \begin{tabular}{|l|}
-1.66 \\
-1.69
\end{tabular} & \begin{tabular}{|l|l|}
1.66 \\
169
\end{tabular} & & & & & & & & & & \\
\hline & & Akses kepada dukungan & & 1.42 & 0.86 & 0.95 & 0.81 & & 171 & 171 & & & & & & & & & & \\
\hline 4 & After-Sales Phase & pelanggan & \begin{tabular}{|l} 
EOU06 \\
\end{tabular} & 1.42 & & & 0.01 & 1.67 & \begin{tabular}{|l}
-1.71 \\
\end{tabular} & 1.71 & -3.42 & 3.42 & $74.38 \%$ & 0.98 & 2.84 & 28.5 & & & & \\
\hline & & Kinerja dari dukungan pelanggan & USEFO9 & 1.42 & 0.86 & 1.00 & 0.86 & & -1.71 & 1.71 & & & & & & & & & & \\
\hline & & \begin{tabular}{|l|}
$\begin{array}{l}\text { Akses ke sebuah komunitas } \\
\text { virtual }\end{array}$ \\
\end{tabular} & EOU07 & 0.79 & 0.70 & 0.63 & 0.44 & & -1.40 & 1.40 & & & & & & & & & & \\
\hline & Community & $\begin{array}{l}\text { Keuntungan dari relasi-relasi } \\
\text { didalam komunitas }\end{array}$ & USEF10 & 0.74 & 0.69 & 0.79 & 0.54 & 70 & \begin{tabular}{|l|}
-1.37 \\
-1.37 \\
\end{tabular} & 1.37 & & & & & & & & & & \\
\hline 5 & Component & Keuntungan dari ketersediaan isi & 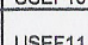 & 079 & 0.70 & 0.58 & 0.40 & 1.73 & \begin{tabular}{|l}
-1.01 \\
\end{tabular} & 1.01 & -5.48 & 5.48 & $65.83 \%$ & 0.63 & 2.95 & & & & & \\
\hline & & $\begin{array}{l}\text { didalam komunitas } \\
\text { Pemberdayaan pelanggan yang }\end{array}$ & & & 0.66 & 0.53 & 0.35 & & \begin{tabular}{|l|l|} 
\\
\end{tabular} & 1.40 & & & & & & & & & & \\
\hline & & \begin{tabular}{|l} 
dihasilkan dari komunitas \\
Ketersediaan sistem
\end{tabular} & \begin{tabular}{|l|} 
USEF 12 \\
EOU08 \\
\end{tabular} & $\frac{0.63}{1.58}$ & $\begin{array}{l}0.66 \\
0.90\end{array}$ & $\frac{0.53}{1.58}$ & $\frac{0.35}{1.41}$ & & \begin{tabular}{|l|}
-1.32 \\
-1.79 \\
\end{tabular} & $\frac{1.32}{1.79}$ & & & & & & & & & & \\
\hline & & Desain dari antarmuka pengguna & EOUng & 153 & 0.88 & 1.53 & 1.35 & & 177 & 177 & & & & & & & & & & \\
\hline & & Meningkatkan produktivitas & EO009 & 1.53 & & & & & \begin{tabular}{|l} 
\\
\end{tabular} & 1.77 & & & & & & & & & & \\
\hline & & 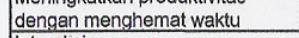 & USEF13 & 1.53 & 0.88 & 1.53 & 1.35 & & \begin{tabular}{|l|}
-1.77 \\
\end{tabular} & 1.77 & & & & & & & & & & \\
\hline 6 & Final Section & \begin{tabular}{|l} 
Interaksi \\
Funsi-
\end{tabular} & \begin{tabular}{|l|l|} 
USEF14 \\
USFE15
\end{tabular} & $\frac{1.42}{0.89}$ & 0.86 & $\frac{1.58}{1.47}$ & $\frac{1.35}{106}$ & 9.29 & \begin{tabular}{|l}
-1.71 \\
.115 \\
\end{tabular} & $\frac{1.71}{1.715}$ & -12.16 & 12.16 & $88.21 \%$ & 1.53 & 10.32 & & & & & \\
\hline & & \begin{tabular}{|l} 
Fungsi-fungsi personalisasi \\
Kepercayaan dari rekan bisnis
\end{tabular} & USEF15 & 0.89 & 0.72 & $\frac{1.47}{1.47}$ & $\frac{1.06}{132}$ & & -1.45 & 1.45 & & & & & & & & & & \\
\hline & & $\begin{array}{l}\text { Kepercayaan dan rekan olsnis } \\
\text { (pemasok) }\end{array}$ & TRUST1 & 1.58 & 0.90 & 1.47 & 1.32 & & -1.79 & 1.79 & & & & & & & & & & \\
\hline & & $\begin{array}{l}\text { Hal yang dapat dipercaya dari } \\
\text { situs web dan situasi legal }\end{array}$ & TRUST2 & 1.79 & 0.95 & 1.53 & 1.45 & & -1.90 & 1.90 & & & & & & & & & & \\
\hline
\end{tabular}




\begin{tabular}{|c|c|c|c|c|c|c|c|c|c|c|c|c|c|c|c|c|c|c|c|c|}
\hline \multicolumn{21}{|c|}{ Sector Protile } \\
\hline No. & Category $\left(K_{k}\right)$ & Criteria (XI) & Code & \begin{tabular}{|l|} 
Importance: $\mathrm{W}_{1}$ \\
$($ Range -21+2)
\end{tabular} & $\begin{array}{l}\text { Importance: } \mathrm{Wg}_{\mathrm{I}} \\
\text { (Range 0-1) }\end{array}$ & \begin{tabular}{|l|}
$\begin{array}{l}\text { Evaluation: Average }\left(r_{1}\right) \\
(\text { Range }-2(+2)\end{array}$ \\
\end{tabular} & $\begin{array}{l}\text { Welghted Value } R_{1,} \\
R_{1}=\text { Wg }{ }_{1}^{*} \text { Average }\left(r_{r}\right)\end{array}$ & $\begin{array}{c}K_{k} \\
\left(\Sigma R_{1}\right)\end{array}$ & $\mathbf{R}_{\text {MNIN }}$ & $R_{\operatorname{maxi}}$ & $K_{\text {MNI }}\left(\sum R_{\text {MNN }}\right)$ & $\left|K_{\max \left(\sum R_{\max }\right)}\right|$ & K\% & $K R_{k}$ & $\mathrm{~kW}_{\mathrm{k}}$ & ks & $\mathbf{R S}_{\text {MNo }}$ & $\mathbf{R S}_{\max }$ & $\mathrm{kS} \%_{\circ}$ & $\mathrm{PR}_{0}$ \\
\hline \multirow{8}{*}{1} & \multirow{8}{*}{ Information Phase } & $\begin{array}{l}\text { Kemudahan akses dari situs web } \\
\text { dan produk-produknya }\end{array}$ & EOU01 & 1.79 & 0.95 & 1.15 & 1.09 & \multirow{8}{*}{5.66} & -1.90 & 1.90 & \multirow{8}{*}{-13.87} & \multirow{8}{*}{13.87} & \multirow{8}{*}{$70.40 \%$} & \multirow{8}{*}{0.82} & \multirow{8}{*}{11.73} & & \multirow{26}{*}{-43.4} & \multirow{26}{*}{43.4} & \multirow{26}{*}{$66.73 \%$} & \multirow{26}{*}{0.67} \\
\hline & & Struktur isi & EOU02 & 1.68 & 0.92 & 1.15 & 1.06 & & -1.84 & 1.84 & & & & & & & & & & \\
\hline & & Kuantitas informasi & EOUO3 & $\frac{1.84}{1.94}$ & 0.96 & 1.09 & 1.05 & & $\frac{-1.92}{1.02}$ & $\frac{1.92}{102}$ & & & & & & & & & & \\
\hline & & Kualitas isi & USEF01 & 1.84 & 0.96 & 0.99 & 0.95 & & -1.92 & 1.92 & & & & & & & & & & \\
\hline & & $\begin{array}{l}\text { Menyampaikan manfaat-manfaat } \\
\text { dari harga }\end{array}$ & USEF02 & 1.32 & 0.83 & 0.70 & 0.58 & & -1.66 & 1.66 & & & & & & & & & & \\
\hline & & \begin{tabular}{|l} 
Membunundel produk-produk dan \\
lavananal-layanannya
\end{tabular} & USEF03 & 1.21 & 0.80 & 0.52 & 0.42 & & -1.61 & 161 & & & & & & & & & & \\
\hline & & 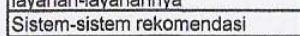 & USEF04 & 1.26 & 0.82 & 0.27 & 0.22 & & $\frac{-1.01}{-1.63}$ & $\frac{1.61}{1.63}$ & & & & & & & & & & \\
\hline & & $\begin{array}{l}\text { Menggunakan hypermedia } \\
\end{array}$ & USEF05 & 0.79 & 0.70 & 0.42 & 0.29 & & -1.40 & 1.40 & & & & & & & & & & \\
\hline \multirow{2}{*}{2} & \multirow{2}{*}{ Agreement Phase } & Desain dari prosedur pemesanan & EOU04 & 1.63 & 0.91 & 0.99 & 0.90 & \multirow{2}{*}{1.49} & -1.82 & 1.82 & \multirow[b]{2}{*}{-3.45} & \multirow{2}{*}{3.45} & \multirow[b]{2}{*}{$71.56 \%$} & \multirow[b]{2}{*}{0.86} & \multirow[b]{2}{*}{2.89} & & & & & \\
\hline & & $\begin{array}{l}\text { Model-model dan metode-metode } \\
\text { penetapan harga }\end{array}$ & USEF0 6 & 1.26 & 0.82 & 0.72 & 0.59 & & -1.63 & 1.63 & & & & & & & & & & \\
\hline \multirow{3}{*}{3} & \multirow{3}{*}{ Settlement Phase } & $\begin{array}{l}\text { Integrasi dari layanan-layanan } \\
\text { umum }\end{array}$ & EOUO5 & 1.37 & 0.84 & 0.51 & 0.43 & & -1.69 & 1.69 & & & & & & & & & & \\
\hline & & $\begin{array}{l}\text { Integrasi dari aplikasi-aplikasi e- } \\
\text { commerce }\end{array}$ & USEF07 & 1.32 & 0.83 & 0.44 & 0.37 & 1.19 & -1.66 & 1.66 & -5.03 & 5.03 & $61.84 \%$ & 0.47 & 4.06 & & & & & \\
\hline & & \begin{tabular}{|l} 
Perutean dan penelusuran \\
\end{tabular} & USEF08 & 1.37 & 0.84 & 0.47 & 0.40 & & -1.69 & 1.69 & & & & & & & & & & \\
\hline 4 & After-Sales Phase & $\begin{array}{l}\text { Akses kepada dukungan } \\
\text { pelanggan }\end{array}$ & EOU06 & 1.42 & 0.86 & 0.49 & 0.42 & 0.69 & -1.71 & 1.71 & -3.42 & 3.42 & $60.13 \%$ & 0.41 & 2.84 & 14.52 & & & & \\
\hline & & Kinerja dari dukungan pelanggan & USEF09 & 1.42 & 0.86 & 0.32 & 0.27 & & -1.71 & 1.71 & & & & & & & & & & \\
\hline & & $\begin{array}{l}\text { Akses ke sebuah komunitas } \\
\text { virtual }\end{array}$ & EOU07 & 0.79 & 0.70 & 0.04 & 0.03 & & -1.40 & 1.40 & & & & & & & & & & \\
\hline & & $\begin{array}{l}\text { Keuntungan dari relasi-relasi } \\
\text { didalam komunitas }\end{array}$ & USEF 10 & 0.74 & 0.69 & 0.14 & 0.10 & & $-1,37$ & 1.37 & & & & & & & & & & \\
\hline 0 & Component & $\begin{array}{l}\text { Keuntungan dari ketersediaan isi } \\
\text { didalam komunitas }\end{array}$ & USEF11 & 0.79 & 0.70 & 0.14 & 0.10 & 0.27 & -1.40 & 1.40 & -5.48 & 5.48 & $52.44 \%$ & 0.10 & 2.95 & & & & & \\
\hline & & Pemberdayaan pelanggan yang & & & 0.66 & & 0.05 & & 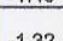 & . & & & & & & & & & & \\
\hline & & $\begin{array}{l}\text { dihasilkan dari komunitas } \\
\text { Kotersedians sistem }\end{array}$ & $\frac{\text { USEF12 }}{\text { EOU08 }}$ & $\frac{0.63}{1.58}$ & 0.90 & 0.09 & $\frac{0.05}{0.89}$ & & $\frac{-1,32}{-1.79}$ & $\frac{1.32}{1.79}$ & & & & & & & & & & \\
\hline & & $\begin{array}{l}\text { Ketersecilaan sistem } \\
\text { Desain dari antarmuka pengguna }\end{array}$ & EOU09 & 1.53 & 0.88 & 0.91 & 0.80 & & -1.77 & 1.77 & & & & & & & & & & \\
\hline & & $\begin{array}{l}\text { Meningkatkan produktivitas } \\
\text { dengan menghemat waktu }\end{array}$ & USEF13 & 1.53 & 0.88 & 0.96 & 0.85 & & -1.77 & 7 & & & & & & & & & & \\
\hline 6 & Final Section & Interaksi & \begin{tabular}{|l|l|} 
USEF14 \\
USEF15
\end{tabular} & $\frac{1.42}{0.89}$ & 0.86 & 0.80 & 0.68 & 5.23 & $\frac{-1.71}{-1.45}$ & $\begin{array}{l}1.71 \\
1.45 \\
\end{array}$ & -12.16 & 12.16 & $71.51 \%$ & 0.86 & 10.32 & & & & & \\
\hline & & \begin{tabular}{|l} 
Fungsi-fungsi personallasas I \\
Kepercayan dari rekan bisnis
\end{tabular} & USEF15 & 0.89 & 0.72 & 0.41 & 0.30 & & -1.45 & 1.45 & & & & & & & & & & \\
\hline & & (pemasok) & TRUST1 & 1.58 & 0.90 & 0.93 & 0.83 & & -1.79 & 1.79 & & & & & & & & & & \\
\hline & & $\begin{array}{l}\text { Hal yang dapat dipercaya adarl } \\
\text { situs web dan situasi legal }\end{array}$ & TRUST2 & 1.79 & 0.95 & 0.93 & 0.88 & & -1.90 & 1.90 & & & & & & & & & & \\
\hline
\end{tabular}

